\title{
CARCINOMA ESCAMOSO BASALÓIDE NA MUCOSA BUCAL: COMPORTAMENTO CLÍNICO, PROGNÓSTICO E ANÁLISE DA EXPRESSÃO DE PCNA, p53, BAX E BCL-X
}

FERNANDA COSTA GRIZZO DE SAMPAIO GÓES

Tese apresentada à Faculdade de Odontologia de Bauru da Universidade de São Paulo, como parte dos requisitos para obtenção do grau de Doutor em Odontologia, área de Patologia Bucal.

\section{BAURU}

2003 


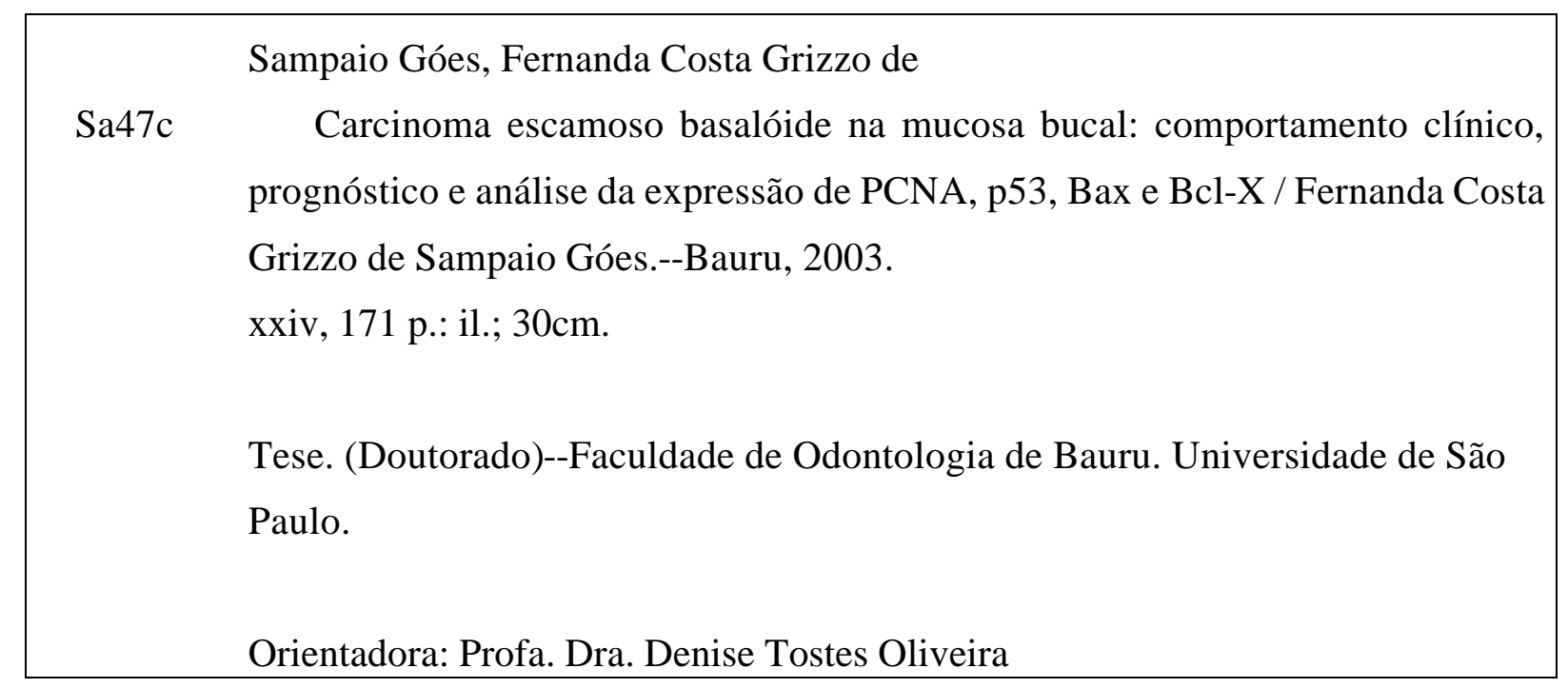

Autorizo, exclusivamente para fins acadêmico e científico, a reprodução total ou parcial desta dissertação / tese, por processos fotocopiadores e / ou meios eletrônicos.

Assinatura do autor:

Data: Bauru, 24 de janeiro de 2003

Projeto de Pesquisa aprovado pelo pela Comissão de Ética em Pesquisa do Hospital do Câncer A.C. Camargo $-\mathrm{n}^{\text {o. }}$ 273/00, em reunião de 29.08.2000.

Projeto de Pesquisa apoiado pela FAPESP - ${ }^{\text {o. }} 00 / 13337-3$ 


\section{FERNANDA COSTA GRIZZO DE SAMPAIO GÓES}

13 de maio de 1970

Jaú - S.P.

Filiação

$1989-1993$

$1998-1999$

$2000-2002$

Associações
Nascimento

Nelson Grizzo

Maria Berenice Costa Grizzo

Curso de Graduação pela Faculdade de Odontologia de Lins.

Mestrado em Patologia Bucal na Faculdade de Odontologia de Bauru, Universidade de São Paulo.

Doutorado em Patologia Bucal na Faculdade de Odontologia de Bauru, Universidade de São Paulo.

APCD - Associação Paulista de CirurgiõesDentistas.

$\mathrm{SBPqO}$ - Sociedade Brasileira de Pesquisas Odontológicas. 
“A dificuldade na vida não é fazer esforço, mas fazê-lo constantemente. Querer com energia sempre, eis a condição indispensável ao êxito, talvez mesmo a única condição necessária." 


\section{DEDICATÓRIA}

Aos pacientes e seus familiares, pelo exemplo de força e perseverança inesgotáveis. 
À minha orientadora Professora Doutora Denise Tostes Oliveira, primeiramente agradeço a confiança em mim depositada e a oportunidade de realização deste trabalho. Agradeço sua generosidade, paciência e principalmente sua competente orientação cientifica, proporcionando-me um enriquecimento profissional e um amadurecimento pessoal imensuráveis.

Meus sinceros agradecimentos! 
Ao meu co-orientador Doutor Gilles Landman, agradeço a dedicação e o incentivo constantes durante este trabalho, pontuado por sua grande competência profissional. 
Ao Doutor Luiz Paulo Kowalski, exemplo de pesquisador, um especial agradecimento ao incentivo constante e a fundamental colaboração neste trabalho. 
AGRADECIMENTOS ESPECIAIS

Ao meu marido Carlito, esteio da minha vida, agradeço sua incansável compreensão, seu apoio e seu amor constante.

Aos meus pais Nelson e Berenice e ao meu irmão Vicente, pela fonte de força, pela compreensão e amor infinitos.

Meus sinceros agradecimentos à querida amiga e companheira Mariza Akemi Matsumoto e aos seus familiares, pelo carinho e generosidade com que sempre me acolheram 


\section{AGRADECIMENTOS}

Aos professores da Disciplina de Patologia da Faculdade de Odontologia de Bauru, Dra. Vanessa Soares Lara, Dr. Luís Antônio de Assis Taveira, Dr. Alberto Consolaro e, especialmente Dra. Denise Tostes Oliveira, pelo meu aprimoramento profissional e convívio amigo.

Ao Doutor Humberto Torloni, pelo incentivo e concessão dos recursos do Instituto Ludwig de Pesquisa sobre o Câncer.

Ao Doutor Fernando Soares, pela atenção e contribuição indispensáveis para a complementação das análises imuno-histoquímicas deste trabalho.

À professora Inês Nobuko Nishimoto, pela competência na orientação estatística, pelo carinho e amizade sempre ofertada.

À química e farmacêutica, Suely Nonogaki, responsável pelo setor de imuno-histoquímica do Instituto Ludwig de Pesquisa sobre o Câncer, pela orientação e realização das reações imuno-histoquímicas deste trabalho.

À querida amiga Regina Garcia Dorta, pelo incentivo e competência vitais para a idealização deste trabalho, pela amizade e paciência constantes.

Ao João Paulo Papa, pela presteza e dedicação no auxílio da captura das imagens microscópicas avaliadas neste trabalho, meu muito obrigada. 
Aos funcionários da Disciplina de Patologia da Faculdade de Odontologia de Bauru, Sras. Bernadete, Fátima, Maria Cristina e Sr. Valdir, agradeço o apoio constante, o carinho e amizade.

A todos os funcionários da Biblioteca da Faculdade de Odontologia de Bauru, em nome de Cybelle de Assumpção Fontes, pela atenção e presteza oferecidas durante todo o curso.

A todos os funcionários da secretaria de Pós-Graduação da Faculdade de Odontologia de Bauru, especialmente a Giane Tenório Quintela e Aurélio Tsuguio Sakuma, pela presteza com que sempre atenderam às minhas solicitações.

A Profa. Dra. Maria do Rosário Dias de Oliveira Latorre, pela atenção e pelos ensinamentos transmitidos na área da Estatística.

À Dra. Renata de Almeida Coudry pela gentileza sempre dispensada no Departamento de Anatomia Patológica do Hospital do Câncer A.C. Camargo.

Aos técnicos do Laboratório de Histologia, da Fundação Antônio Prudente - Hospital do Câncer A.C. Camargo, Miyuki FuKuda da Silva e Carlos Ferreira Nascimento pela elaboração do material analisado neste trabalho. 
Às funcionárias do Centro de Estudos do Hospital do Câncer A.C. Camargo, Ana Lúcia, Claudete, Júlia e Raimunda pela atenção, carinho e incentivo sempre demonstrados.

A todos os funcionários do Departamento de Cirurgia de Cabeça e Pescoço e Otorrinolaringologia do Hospital do Câncer A.C. Camargo, especialmente à Rita de Cássia, pela atenção e presteza constantes.

À Ana Maria e Márcia, funcionárias da secretaria de Pós-Graduação do Hospital do Câncer A.C.Camargo pela gentileza sempre dispensada.

A todos os funcionários do setor administrativo e do laboratório do Departamento de Anatomia Patológica do Hospital do Câncer A.C. Camargo, e pela atenção e carinho com que sempre me receberam.

A todos os funcionários do Serviço de Arquivo Médico, em especial a Sra. Hirde Contesini, pela prontidão com que sempre atenderam às minhas solicitações.

A todos os funcionários da Biblioteca do Hospital do Câncer A.C. Camargo, pela atenção e presteza demonstradas.

Aos queridos amigos, Daniel Araki Ribeiro, Eliana Minicucci e Laurenano Pelegrini, cúmplices em mais esta etapa da minha vida, um agradecimento especial ao apoio e carinho constantemente presentes em nosso convívio. 
Aos amigos de pós-graduação, especialmente aos companheiros do Mestrado e Doutorado em Patologia Bucal, pela atenção e carinho. 


\section{AGRADECIMENTOS INSTITUCIONAIS}

À Direção da Faculdade de Odontologia de Bauru, Universidade de São Paulo, na pessoa da Diretora, Professora Doutora Maria Fidela de Lima Navarro.

À Comissão de Pós-Graduação da Faculdade de Odontologia de Bauru, na pessoa do Presidente, Professor Doutor José Carlos Pereira.

Ao coordenador do curso de Pós-graduação em Patologia Bucal, Professor Doutor Alberto Consolaro.

A CAPES, pelo auxílio pecuniário.

À FAPESP pelo auxílio pecuniário imprescindivel para a realização deste projeto de pesquisa. 


\section{SUMÁRIO}

LISTA DE FIGURAS - xvi

LISTA DE TABELAS - xix

LISTA DE ABREVIATURAS E SÍMBOLOS ～xxi

RESUMO Xxiv

1 INTRODUÇÃO 1

2 REVISÃO DA LITERATURA 6

2.1 Carcinoma Escamoso Basalóide 7

2.2 Carcinoma Escamoso Basalóide na Mucosa Bucal 18

2.3 Carcinoma Escamoso Basalóide X Carcinoma Espinocelular $\quad 24$

2.4 Marcadores imuno-histoquímicos associados a proliferação e apoptose 37

3 PROPOSIÇÃO $\quad 50$

4 MATERIAL E MÉTODOS 52

4.1 População de estudo e seleção da amostra 53

4.2 Registro dos dados clínicos e microscópicos 56

4.3 Análise microscópica $\quad 56$

4.4 Variáveis de estudo $\quad 57$

4.5 Método imuno-histoquímico $\quad 60$

4.6 Avaliação imuno-histoquímica $\quad 62$

4.7 Análise estatística $\quad 64$

4.8 Registro fotográfico $\quad 65$

4.9 Questões éticas $\quad 65$

5 RESULTADOS 66

$\begin{array}{ll}5.1 \text { Casuística } & 67\end{array}$

5.2 Caracterização demográfica e clínica da população de estudo segundo grupo $\quad 67$ 
5.3 Análise morfológica dos carcinomas

5.3.1 Carcinoma escamoso basalóide

5.3.2 Carcinoma espinocelular pouco diferenciado 82

5.4 Análise imuno-histoquímica dos carcinomas 90

5.5 Análise estatística

5.5.1 Análise de sobrevida

6 DISCUSSÃO

7 CONCLUSÃO

ANEXOS

REFERÊNCIAS BIBLIOGRÁFICAS 


\section{LISTA DE FIGURAS}

FIGURA 1 - $\quad$ A e B - Padrão de invasão compressivo do CEB, configuração tumoral em lóbulos/ilhotas, com comedonecrose central e disjunção epitélio tumoral/conjuntivo. (HE, aumento original $\mathrm{A}=50 \mathrm{x}$ e $\mathrm{B}=100 \mathrm{x}$ )

FIGURA 2 - CEB com células basalóides periféricas dispostas em paliçada, caracterizadas por escasso citoplasma, ausência de pontes intercelulares (A). Em B destacam-se numerosas figuras de mitoses. (HE, aumento original $A=400 x$ e $B=1000 x$ )

FIGURA 3 - Componente escamoso associado ao CEB. Observar presença de células escamosas e de pérola córnea em continuidade com as células basalóides. (HE, aumento original $\mathrm{A}=100$ e $\mathrm{B}=400 \mathrm{x}$ )

FIGURA 4 - $\quad$ CEB em continuidade com a mucosa bucal (A). Em B, as células basalóides encontram-se organizadas em estruturas ductiformes. (HE, aumento original $\mathrm{A}=50 \mathrm{x}$ e PAS, aumento original $\mathrm{B}=100 \mathrm{x}$ )

FIGURA 5 - $\quad$ CEB apresentando extensas áreas de disjunção epitélio tumoral/tecido conjuntivo e hialinização intra e peritumoral (A e B). (PAS, aumento original $A=50 x$ e $B=100 x$ )

FIGURA 6 - $\quad$ Presença de material hialino (A), PAS positivo (B) entre as células basalóide do CEB. (HE, aumento original A=400x e PAS, aumento original 400x)

FIGURA 7 - Ilhota tumoral exibindo material hialino PAS positivo (A), circundando as células basalóides do CEB. (PAS, aumento original $\mathrm{A}=100 \mathrm{x}$ e $\mathrm{B}=$ $400 x)$

FIGURA 8 - $\quad$ CEC com padrão de invasão tumoral infiltrativo em cordões finos (A). Observar o pleomorfismo celular e as numerosas figuras de mitoses. (B). (HE, aumento original $A=100 x$ e $B=400 x$ )

FIGURA 9 - Observar a atipia celular caracterizada por intenso pleomorfismo, hipercromatismo e numerosas figuras de mitoses atípicas. (HE, aumento original $\mathrm{A}=400 \mathrm{x}$ e $\mathrm{B}=1000 \mathrm{x}$ ) 
FIGURA 10 - Invasão do plano muscular pelos cordões e ilhotas tumorais do CEC (A e $B$ ). (HE, aumento original $A=100 x$ e $B=400 x$ )

FIGURA 11 - Infiltração perineural pelo CEC (HE, aumento original A=100x e $B=40 x)$

FIGURA 12 - Imunoexpressão do PCNA no CEB (A e B). Observar a imunopositividade nas ilhotas tumorais, exceto nas células neoplásicas centrais próximas à comedonecrose. (IHQ, aumento original $\mathrm{A}=50 \mathrm{x}$ e $\mathrm{B}=100 \mathrm{x})$

FIGURA 13 - Imunoexpressão do PCNA no CEC (A e B). A intensa imunopositividade ao PCNA foi observado na maioria das células neoplásicas pouco diferenciadas. (IHQ, aumento original $\mathrm{A}=100 \mathrm{x}$ e $B=400 x)$

FIGURA 14 - Imunoexpressão da proteína p53 no CEB (A e B). Observar a imunopositividade das células basalóides à proteína p53. (IHQ, aumento original $\mathrm{A}$ e $\mathrm{B}=400 \mathrm{x}$ )

FIGURA 15 - Imunoexpressão da proteína p53 no CEC (A e B). Em destaque, a intensa imunopositividade ao p53 das células neoplásicas pouco diferenciadas. (IHQ, aumento original $A=100 x$ e $B=400 x$ )

FIGURA 16 - Imunoexpressão de Bax no CEB (A e B). A expressão da proteína Bax foi observada intensamente no citoplasma da células basalóides (IHQ, aumento original $\mathrm{A}$ e $\mathrm{B}=400 \mathrm{x}$ )

FIGURAS 17 - Expressão citoplasmática intensa da proteína Bax observada no CEC. (A e B) (IHQ, aumento original A e B=400x)

FIGURA 18 - Imunoexpressão de Bcl-X no CEB (A e B). A expressão da proteína Bcl-X foi observada intensamente no citoplasma das células basalóides (IHQ, aumento original A e B=400x)

FIGURA 19 - Imunoexpressão de Bcl-X no CEC (A e B). A expressão da proteína Bcl-X foi observada intensamente no citoplasma das células escamosas. (IHQ, aumento original A e B=400x) 
FIGURA - 20 Sobrevida global dos pacientes com carcinoma escamoso basalóide e com carcinoma espinocelular pouco diferenciado de boca. Porcentagem de sobrevida acumulada pela técnica de Kaplan-Meier

FIGURA - 21 Sobrevida específica dos pacientes com carcinoma escamoso basalóide e com carcinoma espinocelular pouco diferenciado de boca. Porcentagem de sobrevida acumulada pela técnica de Kaplan-Meier

FIGURA - 22 Sobrevida livre de doença dos pacientes com carcinoma escamoso basalóide e com carcinoma espinocelular pouco diferenciado de boca. Porcentagem de sobrevida acumulada pela técnica de Kaplan-Meier. 


\section{LISTA DE TABELAS}

TABELA 1 - Análise comparativa do carcinoma escamoso basalóide e do carcinoma espinocelular, segundo localização e evolução clínica

TABELA 2 - Distribuição dos carcinomas escamosos basalóides e carcinomas espinocelulares pouco diferenciados de boca, quanto aos critérios de inclusão estabelecidos. Hospital do Câncer, São Paulo, 1970 a 2000

TABELA 3 - Distribuição das características demográficas e da história clínica dos pacientes com carcinoma escamoso basalóide e com carcinoma espinocelular pouco diferenciado de boca. Hospital do Câncer, São Paulo, 1970 a 2000

TABELA 4 - Distribuição das características clínicas dos pacientes com carcinoma escamoso basalóide e com carcinoma espinocelular pouco diferenciado de boca. Hospital do Câncer, São Paulo, 1970 a 2000

TABELA 5 - Distribuição do tratamento e da evolução dos pacientes com carcinoma escamoso basalóide e com carcinoma espinocelular pouco diferenciado de boca. Hospital do Câncer, São Paulo, 1970 a 2000

TABELA 6 - Distribuição das características morfológicas do carcinoma escamoso basalóide. Hospital do Câncer, São Paulo, 1970 a 2000

TABELA 7 - Distribuição das características morfológicas do carcinoma espinocelular pouco diferenciado. Hospital do Câncer, São Paulo, 1970 a 2000

TABELA 8 - Distribuição das características morfológicas do carcinoma escamoso basalóide e do carcinoma espinocelular pouco diferenciado de boca. Hospital do Câncer, São Paulo, 1970 a 2000

TABELA 9 - Distribuição da expressão imuno-histoquímica dos anticorpos PCNA e p53 nos carcinomas escamosos basalóides e nos carcinomas espinocelulares pouco diferenciados de boca. Hospital do Câncer, São Paulo, 1970 a 2000 
TABELA 10 - Distribuição da expressão imuno-histoquímica dos anticorpos Bax e Bcl-X nos carcinomas escamosos basalóides e nos carcinomas espinocelulares pouco diferenciados de boca. Hospital do Câncer, São Paulo, 1970 a 2000

TABELA 11 - Análise de sobrevida global. Probabilidade de sobrevida acumulada pela técnica de Kaplan-Meier

TABELA 12 - Análise de sobrevida específica. Probabilidade de sobrevida acumulada pela técnica de Kaplan-Meier

TABELA 13 - Análise de sobrevida livre de doença. Probabilidade de sobrevida acumulada pela técnica de Kaplan-Meier

TABELA 14 - $\quad$ Análise de sobrevida específica pelo modelo de Cox 


\section{LISTA DE ABREVIATURAS}

$\mu \mathrm{m}-$ micrometro

000 - vivo livre de doença

$34 \beta \mathrm{E} 12$ - citoqueratina $34 \beta \mathrm{E} 12$

$35 \beta \mathrm{H} 11$ - citoqueratina $35 \beta \mathrm{H} 11$

$\mathrm{AE} / 1$ - citoqueratina AE/1

$\mathrm{AE} / 2$ - citoqueratina $\mathrm{AE} / 2$

AgNORs - argyrophilic nuclear organizer regions

$A P C$ - adenomatous polyposi coli

Bax - Bcl-2 homologous antagonist

Bcl-2 - B-cell lymphoma-2

Bcl-X - Bcl-2 homolugous-X

Bcl- $\mathrm{X}_{\mathrm{L}}-\mathrm{Bcl}-2$ homologous-X long

Bcl-X - Bcl-2 homologous-X short

BSA - bovine serum albumine

$\mathrm{Ca}$ - carcinoma

CAM5.2 - ciytokeratin CAM5.2

CDK4 - cyclin dependent kinase 4

CEA - carcinoembryonic antigen

CEB - carcinoma escamoso basalóide

CEC - carcinoma espinocelular

CEC I - carcinoma espinocelular bem diferenciado

CEC II - carcinoma espinocelular moderadamente diferenciado

CEC III - carcinoma espinocelular pouco diferenciado

CEP - comissão de ética em pesquisa

CK14 - cytokeratin 14

CK19 - cytokeratin 19

CK7 - cytokeratin 7

CK8 - cytokeratin 8

$c-m y c$ - cell-avian myelocytomatosis 
DAB - diaminobenzidine Tetradydrochloride

DMSO - dimetilsulfóxido

DNA - deoxyribonucleic acid

G1 - gap 1

G2 - gap 2

$\mathrm{H}_{2} \mathrm{O}_{2}$ - peróxido de hidrogênio

HE - hematoxilina e eosina

IHQ - imuno-histoquímica

$\mathrm{kDa}$ - kilodalton

Ki-67 - Kiel $67^{\mathrm{a}}$ culture dishe, monoclonal antibody which reconizes a labille epitope on a nuclear antigen in cycling cells

$M C C$ - mutated in colorectal cancer

MIB-1 - Ki-67 analogous monoclonal antibody

$\mathrm{mM}-$ milimol

MMP-1 - matrix metalloproteinase 1

MMP-2 - matrix metalloproteinase 2

MMP-9 - matrix metalloproteinase 9

MMPs - matrix metalloproteinases

Moass - morte sem evidência de recidiva do tumor primário

Moca - morte decorrente do tumor primário

Moci - morte por intercorrência cirúrgica

mRNA - messenger ribonucleic acid

$\mathrm{N}+$ - presença de metástase em linfonodos regionais

NO - ausência de metástase em linfonodos regionais

N1 - metástase em um único linfonodo homolateral, com $3 \mathrm{~cm}$ ou menos em sua maior dimensão, segundo a classificação TNM para tumores malignos de boca

N2 - metástase em um único linfonodo homolateral, com mais de $3 \mathrm{~cm}$ ou até $6 \mathrm{~cm}$ em sua maior dimensão, ou em linfonodos homolaterais múltiplos, nenhum deles com mais de $6 \mathrm{~cm}$ em sua maior dimensão, ou em linfonodos bilaterais ou contralaterais, nenhum deles com mais de $6 \mathrm{~cm}$ em sua maior dimensão, segundo a classificação TNM para tumores malignos de boca 
N3 - metástase em linfonodo com mais de $6 \mathrm{~cm}$ em sua maior dimensão, segundo a classificação TNM para tumores malignos de boca

OMS - Organização Mundial da Saúde

p53 - a $53 \mathrm{kDa}$ protein

TP53 - tumor supressor gene

PAS - ácido periódico de Schiff

PBS - phosphate buffered saline

PCNA - proliferating cell nuclear antigen

$\mathrm{pH}$ - hydrogen ion concentration

$R B$ - retinoblastoma

RT-PCR - reverse transcriptase polimerase chain reaction

$\mathrm{S}$ - synthesis

SAME - serviço de arquivo médico

StretpABComplex - streptavidin and biotinylated peroxidase complex

T1 - tumor com $2 \mathrm{~cm}$ ou menos em sua maior dimensão, segundo a classificação TNM para tumores malignos de boca

T2 - tumor com mais de $2 \mathrm{~cm}$ e até $4 \mathrm{~cm}$ em sua maior dimensão, segundo a classificação TNM para tumores malignos de boca

T3 - tumor com mais de 4cm em sua maior dimensão, segundo a classificação TNM para tumores malignos de boca

T4 - tumor com mais de $4 \mathrm{~cm}$ em sua maior dimensão, invadindo estruturas adjacentes, segundo a classificação TNM para tumores malignos de boca

TNM - classificação dos tumores malignos

UICC - União Internacional Contra o Câncer 


\section{RESUMO}

O carcinoma escamoso basalóide (CEB) tem sido considerado uma das variantes mais agressivas do carcinoma espinocelular (CEC), acometendo preferencialmente a base da língua, a hipofaringe e a laringe. Um total de 776 carcinomas espinocelulares primários de boca, cirurgicamente excisados entre 1970 e 2000, foram revisados dos arquivos dos Departamentos de Patologia e de Cirurgia de Cabeça e Pescoço e Otorrinolaringologia do Hospital do Câncer A.C. Camargo. Dezessete CEBs foram identificados e analisados comparativamente a $27 \mathrm{CECs}$ pouco diferenciados com estadiamento e localização equivalentes, quanto ao gênero, idade, raça, tabagismo, etilismo, localização do tumor primário, classificação pelo sistema TNM, tratamento, ocorrência de recidiva tumoral, metástases em linfonodos regionais, a distância e de segundo tumor primário. Analisaram-se a morfologia tumoral e a expressão dos marcadores de proliferação celular e apoptose: PCNA, p53, Bax e Bcl-X. As probabilidades de sobrevida, acumuladas nos períodos de 5 e 10 anos para ambos grupos tumorais, foram calculadas pelo método de Kaplan-Meier, sendo a influência das variáveis clínicas e microscópicas no prognóstico avaliada pelo modelo de regressão de Cox. Morfologicamente, a maioria dos CEBs apresentou configuração tumoral sólida/lobular, disposição em paliçada das células periféricas, espaços císticos, comedonecrose, hialinização intra e peritumoral, disjunção epitélio tumoral/conjuntivo e associação com o componente escamoso. Nenhuma diferença estatística foi detectada entre os grupos CEB e CEC quanto às características demográficas, clínicas e quanto à expressão dos marcadores PCNA, p53 e Bcl-X. O CEB apresentou, comparativamente ao CEC, maior expressão da proteína Bax $(p=0,031)$. As probabilidades de sobrevida global, sobrevida específica e sobrevida livre de doença acumuladas em 5 e 10 anos para os pacientes com CEB e com CEC foram semelhantes. O estadiamento clínico $\mathrm{N}$ constituiu um fator prognóstico independente para os pacientes com carcinoma escamoso basalóide e carcinoma espinocelular pouco diferenciado na mucosa bucal. A morfologia tumoral, bem como a expressão dos anticorpos PCNA, p53, Bax e Bcl-X, não foram fatores prognósticos significativos. Estes resultados sugerem que, o CEB e o CEC pouco diferenciado com localização e estadiamento clínico equivalentes na boca, apresentam comportamento clínico e biológico similares. Assim sendo, os pacientes acometidos por estes tumores podem ser submetidos aos mesmos protocolos terapêuticos. 
1 INTRODUÇÃO 


\section{INTRODUÇÃO}

O carcinoma escamoso basalóide foi caracterizado inicialmente por WAIN et al. ${ }^{130}$, em 1986, como uma variante morfológica distinta do carcinoma espinocelular.

Embora um perfil clínico bastante semelhante quanto ao gênero e idade dos pacientes, bem como associação com fatores de risco como tabaco e álcool ${ }^{1,7,13,26,34,74,92,100}$, tenham sido relatados entre o carcinoma espinocelular e o escamoso basalóide, o comportamento clínico deste último é considerado mais agressivo por alguns autores ${ }^{2,3,24,26,34,79,134}$. Estas afirmativas referentes à agressividade do carcinoma escamoso basalóide são baseadas, principalmente, na ocorrência de invasão perineural, vascular, muscular e óssea ${ }^{1,2,3,22,26,132}$, e na freqüente ocorrência de metástases regional ${ }^{1,7,13,22,26,50,51,68,80,131}$ e a distância ${ }^{7,13,26,34,50,51,68,131}$, sendo sítios comuns os pulmões e o fígado ${ }^{34,74}$. A maioria dos pacientes com carcinoma escamoso basalóide é diagnosticada em estádios clínicos avançados ${ }^{1,7,13,26,74,100}$, apresentando pequena probabilidade de sobrevida ${ }^{34,68,79,134}$.

Com relação ao prognóstico, a análise comparativa entre o carcinoma escamoso basalóide e o carcinoma espinocelular apresenta-se controvertida na literatura. Alguns autores ${ }^{24,26,34,79,134}$ relataram um comportamento mais agressivo e um prognóstico pior para os pacientes comprometidos pelo carcinoma escamoso basalóide, enquanto outros consideram seu comportamento clínico similar ao carcinoma espinocelular ${ }^{13,31,60,66,74,100}$. Exclusivamente em boca, poucos estudos ${ }^{2,3,24,26}$ avaliaram, comparativamente, o perfil clínico-microscópico e o comportamento tumoral destas duas neoplasias malignas, sendo as amostras geralmente 
pequenas, não permitindo um delineamento mais consistente do plano de tratamento e do prognóstico.

Microscopicamente, o carcinoma escamoso basalóide apresenta um padrão morfológico bifásico, caracterizado por populações de células basalóides e escamosas. Ocasionalmente, estas características morfológicas distintas podem ser similares às do carcinoma espinocelular, principalmente pouco diferenciado, do carcinoma adenóide cístico, do carcinoma adenoescamoso, do carcinoma escamoso adenóide, das neoplasias neuroendócrinas e do carcinoma indiferenciado de pequenas células $3,13,14,24,25,26,32,33,58$, dificultando o estabelecimento do diagnóstico.

O comportamento biológico agressivo do carcinoma escamoso basalóide associa-se ao seu potencial de proliferação celular e invasão tecidual. Esta atividade proliferativa tem sido

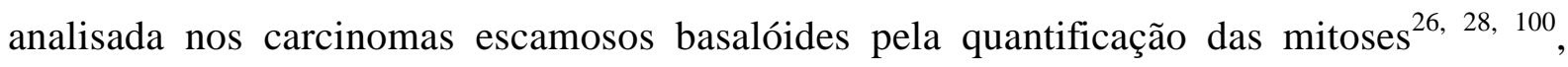
AgNORs ${ }^{3,24,28}$, pela imunomarcação com PCNA ${ }^{6,24,28}, \mathrm{MIB}^{34,66,100}$ e Ki-67 ${ }^{34}$.

Investigações como de SARBIA et al. ${ }^{100,101}$, FERLITO et al. $^{34}$, ABIKO et al. ${ }^{3}$, COTRIM-ZÚÑIGA et al. ${ }^{28}$, COLETTA et al. ${ }^{24}$, LAM et al. ${ }^{66}$, demonstraram que o carcinoma escamoso basalóide apresenta uma alta atividade proliferativa e um intenso potencial de invasão comparado ao carcinoma espinocelular. Alterações moleculares dos genes p53, $A P C$ e $M C C^{90}$ e $c-m y c^{101}$, envolvidos com uma alta atividade proliferativa tumoral, foram identificados mais freqüentemente no carcinoma escamoso basalóide de esôfago quando comparado ao carcinoma espinocelular.

O crescimento tumoral como o do carcinoma escamoso basalóide, depende diretamente dos genes responsáveis pela proliferação celular e apoptose. A expressão de 
proteínas envolvidas com a apoptose como as proteínas antiapoptóticas Bcl-2 e Bcl-X e próapoptóticas como Bax e p53, também têm sido analisadas nos carcinomas espinocelulares visando ampliar o conhecimento dos genes envolvidos na patogênese tumoral, bem como da sua influência no prognóstico dos pacientes.

Um maior índice apoptótico do carcinoma escamoso basalóide comparado ao carcinoma espinocelular de esôfago foi identificado por SARBIA et al. ${ }^{100}$. Posteriormente, SARBIA et al. ${ }^{101}$, em 1999 e OWONIKOKO et al. ${ }^{90}$, em 2001, demonstraram diferenças moleculares entre estas duas neoplasias malignas no esôfago. O carcinoma escamoso basalóide apresentou uma alta expressão da proteína Bcl-2 e concomitantemente, a amplificação do gene $c-m y c$ foi duas vezes maior neste espécime tumoral. Esta evidência sugeriu uma atividade cooperativa entre os genes bcl-2 e c-myc no desenvolvimento do carcinoma escamoso basalóide ${ }^{101}$.

A análise de fatores como atividade proliferativa e apoptótica caracterizam o perfil biológico dos tumores podendo influenciar o prognóstico dos pacientes acometidos pelos carcinomas escamosos basalóides e espinocelulares. Os estudos pertinentes ao carcinoma escamoso basalóide de boca são escassos, não permitindo um delineamento do comportamento deste tumor neste sítio anatômico.

Assim sendo, o objetivo deste estudo consiste na caracterização demográfica, clínica, morfológica e na avaliação do prognóstico dos pacientes com carcinoma escamoso basalóide localizados, primariamente na mucosa bucal. Pretende-se também, comparar o carcinoma escamoso basalóide e o carcinoma espinocelular pouco diferenciado de boca, com estadiamento clínico e localização equivalentes, quanto aos aspectos demográficos, clínicos, morfológicos e imuno-histoquímicos relativos às atividades proliferativas e apoptóticas, bem 
como ao prognóstico. O conhecimento dos aspectos clínicos e da biologia tumoral do carcinoma escamoso basalóide visa trazer contribuições para o estabelecimento de um plano de tratamento mais consistente quando de sua ocorrência na mucosa bucal. 
2 REVISÃO DA LITERATURA 


\section{REVISÃO DA LITERATURA}

\subsection{Carcinoma Escamoso Basalóide}

O carcinoma escamoso basalóide foi descrito pela primeira vez e considerado uma entidade patológica distinta por WAIN et al. ${ }^{131}$, em 1986, a partir da análise de dez carcinomas escamosos basalóides localizados na base da língua, hipofaringe e laringe. Os autores verificaram que esta neoplasia maligna apresenta predileção pela região de cabeça e pescoço, acomete predominantente pacientes do gênero masculino, com idades entre 60 e 70 anos e caracteriza-se clinicamente por um aspecto exofítico. Dos dez pacientes analisados, seis apresentaram inicialmente metástases nos linfonodos regionais e quatro destes pacientes apresentaram metástases a distância nos pulmões, pele e cérebro. O tratamento empregado foi o cirúrgico acompanhado de radioterapia em sete pacientes e complementado por quimioterapia em três destes. Posteriormente, mais dois pacientes desenvolveram metástases a distância e em um período de 43 meses, $40 \%$ dos pacientes foram a óbito. Considerou-se então, o carcinoma escamoso basalóide um tumor altamente agressivo.

Microscopicamente ${ }^{131}$, o carcinoma escamoso basalóide caracteriza-se pelo predomínio de células basalóides de pequeno tamanho, citoplasma escasso e núcleo hipercromático sem nucléolos evidentes, com configuração lobular, apresentando continuidade com o epitélio de revestimento. Morfologicamente, outros padrões de organização do componente basalóide como cordões, ilhotas, cribiforme e tubular também foram descritos. Algumas ilhotas tumorais apresentavam pequenos espaços císticos contendo material similar a mucina e positivos ao PAS e/ ou Alcian blue. Nas áreas centrais dos 
lóbulos, observou-se necrose central por coagulação, comedonecrose, e no estroma periférico ou circunvizinho, focos de hialinização.

Outra característica microscópica peculiar descrita por WAIN et al. ${ }^{131}$ foi a associação dos componentes basalóide e escamoso, caracterizando-se este último por ser focal, nas formas carcinoma in situ, ou carcinoma espinocelular francamente invasivo. Alguns dos critérios identificadores para a porção escamosa associada incluíam a presença de queratinização individual de células, pontes intercelulares, formação de pérolas córneas e arranjo pavimentoso ou em mosaico do epitélio estratificado.

À microscopia eletrônica, as células basalóides apresentaram forma poligonal, núcleo claro, contendo cromatina fina e dispersa, apresentando características de malignidade como núcleo grande e irregular com numerosos nucléolos. As células também apresentavam desmossomos relativamente pequenos, evidenciando uma fraca interligação celular, poucos tonofilamentos e poucas organelas. Circundando as ilhotas de células basalóides observou-se membrana basal dupla, replicada. Os microcistos apresentavam-se circundados por membrana basal e preenchidos por grânulos ou aglomerados de lâmina basal. Nas células basalóides, grânulos secretores, neurossecretores, miofilamentos com corpos densos e organização citoplasmática não foram detectados, sugerindo um aspecto indiferenciado a estas células. Foi sugerido pelos autores que as células basalóides precursoras do carcinoma escamoso basalóide da cabeça e pescoço, seriam provenientes de células primitivas totipotentes, localizadas na base do epitélio ou nas proximidades dos ductos das glândulas salivares da laringe, da hipofaringe e da língua. Segundo WAIN et al. ${ }^{131}$, as características microscópicas do carcinoma escamoso basalóide são distintas e específicas, porém podem ser similares ao carcinoma adenóide cístico, principalmente à variante sólida, ao carcinoma adenoescamoso, 
ao carcinoma mucoepidermóide e ao adenoma de células basais. Considerou-se o carcinoma escamoso basalóide da cabeça e pescoço, uma variante do carcinoma espinocelular pouco diferenciado.

Posteriormente ao trabalho de WAIN et al. ${ }^{131}$, a predileção do carcinoma escamoso basalóide pela base da língua, hipofaringe e porção supraglótica da laringe, bem como a dificuldade no estabelecimento do seu diagnóstico em sítios da cabeça e pescoço foram retratadas por BATSAKI, J.G.; EL NAGGAR ${ }^{15}$, A., em 1989. Ressaltou-se esta dificuldade pela falta de representatividade de espécimes provenientes de biópsias, pela dificuldade de visualização do padrão morfológico bifásico, imprescindível para o seu diagnóstico e pela incapacidade de visualização da mucosa sobrejacente e/ou de continuidade com o componente escamoso. A ausência desta última característica freqüentemente conduz ao diagnóstico equivocado de carcinoma adenóide cístico, mais comumente ou de o carcinoma neuroendócrino. Segundo os autores, a diferenciação se faz muito importante, pois o carcinoma escamoso basalóide apresenta um comportamento biológico agressivo e inquestionável, representado pela presença de metástases em linfonodos regionais e desenvolvimento precoce de metástases a distância.

Em um estudo retrospectivo de dez anos, TSANG et al. ${ }^{123}$, em 1991, avaliaram carcinomas não epidermóides da laringe, faringe e esôfago e identificaram nove espécimes de carcinoma escamoso basalóide. Para uma análise imuno-histoquímica comparativa, avaliaram-se quatro espécimes de carcinoma adenóide cístico de laringe quanto à expressão das citoqueratinas AE/1, AE/3 e 34ßE12, CEA, actina, vimentina e proteína S-100. Os autores sugeriram que o carcinoma escamoso basalóide, possui um perfil imuno-histoquímico característico e também que, possui origem nas células primitivas totipotentes, as quais 
apresentam capacidade para diferenciação em células epiteliais, mioepiteliais e em outros elementos, justificando a semelhança deste tumor com o carcinoma espinocelular pouco diferenciado.

Na sequiência, TSANG et al. ${ }^{124}$, em 1992, reforçaram a caracterização das células basalóides do carcinoma escamoso basalóide, em células altamente indiferenciadas, as quais podem exibir uma diferenciação focal escamosa e também podem apresentar uma discreta diferenciação mioepitelial, porém ressaltaram que o carcinoma escamoso basalóide é considerado uma variante pouco comum do carcinoma espinocelular.

A maior e mais significativa amostra constituída por 40 carcinomas escamosos basalóides localizados na região de cabeça e pescoço, foi analisada por BANKS et al. ${ }^{13}$, em 1992, corroborando com a designação proposta por WAIN et al. ${ }^{131}$, de que o carcinoma escamoso basalóide é uma neoplasia com características microscópicas “distintas e específicas". Os tumores localizaram-se em 12 pacientes na base de língua, oito no seio piriforme, oito na laringe, cinco nas tonsilas palatinas, três na faringe, dois na nasofaringe e cavidade nasal e em dois pacientes em regiões não especificada da cabeça e pescoço. Os tumores apresentavam estádios clínicos avançados, e em $68 \%$ dos pacientes verificou-se metástase linfonodal. O tratamento seguiu os mesmos protocolos para pacientes com carcinoma espinocelular com estadiamento e localização equivalentes. Em 26 pacientes realizou-se a ressecção cirúrgica do tumor e 32 pacientes foram submetidos a radio e/ou quimioterapia. Verificou-se que seis pacientes apresentaram recorrência local, em 15 pacientes detectaram-se metástases a distância, sendo em 13 nos pulmões. O período mediano de seguimento foi de 12 meses, neste período 20 pacientes estavam vivos e sete pacientes vivos com a doença. Após o período mediano de 18 meses do diagnóstico, ocorreram 17 
óbitos, dois sem evidência clínica da doença. As características microscópicas relevantes para o diagnóstico do carcinoma escamoso basalóide foram observadas nos 40 espécimes, como a continuidade com o epitélio de revestimento ora displásico, ora representado pelo carcinoma espinocelular convencional. O componente basalóide apresentou configuração em cordões e ilhotas tumorais, com necrose central e também em padrões cribiforme e pseudoglandular. BANKS et al. ${ }^{13}$ enfatizaram a importância da distinção do carcinoma escamoso basalóide das demais neoplasias que apresentem aspectos microscópicos semelhantes e exijam protocolos terapêuticos distintos como nos casos do carcinoma indiferenciado de pequenas células e do carcinoma adenóide cístico, este último caracterizado por apresentar um melhor prognóstico; esta distinção também deve ser feita com o carcinoma espinocelular. Os autores consideraram que o carcinoma escamoso basalóide apresenta um comportamento clínico similar ao carcinoma espinocelular pouco diferenciado.

Outra amostra representativa, de 12 carcinomas escamosos basalóides localizados na hipofaringe, orofaringe, epiglote e base da língua, foram analisados por KLIJANIENKO et al. ${ }^{58}$, em 1993, quanto às características clínicas e imuno-histoquímicas. Quatro pacientes apresentaram comprometimento dos linfonodos regionais e seis pacientes apresentaram metástases a distância, cinco com localização nos pulmões e um no fígado. Cinco pacientes após a cirurgia foram submetidos à radioterapia e outros cinco à quimioterapia; em dois pacientes o tratamento foi apenas quimioterápico. Apesar do curto período de seguimento avaliado, o carcinoma escamoso basalóide, comparativamente, ao carcinoma espinocelular apresentou um comportamento clínico agressivo, caracterizado por um alto índice de metástases linfonodais e a distância. Sugeriu-se que, as marcações imuno-histoquímicas, 
principalmente para vimentina e proteína S-100 podem auxiliar no diagnóstico diferencial entre o carcinoma escamoso basalóide e o carcinoma adenóide cístico.

A efetividade da radioterapia no tratamento do carcinoma escamoso basalóide na região de cabeça e pescoço foi avaliada por LARNER et al. ${ }^{68}$, em 1993, enfatizando as características clínicas e o potencial metastático deste tumor. Em estudo retrospectivo de dez anos, espécimes diagnosticados como carcinomas espinocelulares pouco diferenciados foram revisados, resultando na identificação de 16 carcinomas escamosos basalóides. O tratamento radioterápico inicial foi realizado em 11 pacientes. Em dois pacientes o tratamento foi apenas cirúrgico. A radioterapia apresentou-se eficaz no controle locorregional da doença, porém 50\% dos pacientes desenvolveram metástases a distância, sendo localizadas em seis pacientes nos pulmões e em um paciente nos ossos. Em pacientes com tratamento primariamente cirúrgico foram detectadas metástases em fígado e pele. O período médio livre de doença foi de 20 meses e a taxa de sobrevida acumulada em 24, 48 e 72 meses foi respectivamente, de $80 \%, 65 \%$ e $50 \%$. Os autores concluíram que o carcinoma escamoso basalóide possui características clínicas e microscópicas distintas e que a combinação cirurgia e radioterapia é um método eficaz no controle local deste tumor, mesmo nos estádios clínicos mais avançados.

Em 1994, RASLAN et al. ${ }^{95}$ avaliaram dez espécimes de carcinoma escamoso basalóide da cabeça e pescoço, sendo o local mais acometido a base da língua (50\%) seguido do seio piriforme e epiglote $(30 \%)$ e tonsila palatina (10\%). Metástases em linfonodos regionais foram detectadas inicialmente em $60 \%$ dos pacientes, três deles apresentaram também metástases a distância, nos pulmões e no fígado. O tratamento cirúrgico foi realizado em todos os pacientes, a radioterapia pós-operatória em $20 \%$ e a quimioterapia em $40 \%$ dos pacientes. Todos os espécimes preencheram os critérios microscópicos de WAIN et al. ${ }^{131}$. Os 
autores reafirmaram o comportamento biológico agressivo do carcinoma escamoso basalóide, caracterizado pela alta incidência de metástases em linfonodos regionais observada em $64 \%$ dos pacientes e a distância em 44\%. Verificou-se também que 38\% dos óbitos relacionaramse com a doença, ocorrendo num período mediano de 18 meses.

Na revisão retrospectiva de 468 espécimes de carcinomas de laringe, EREÑO et al. ${ }^{31}$, em 1994, detectaram sete carcinomas escamosos basalóides. Os pacientes apresentaram-se com estádios clínicos avançados. Microscopicamente, verificou-se a predominância do componente basalóide e a presença de pérolas córneas no interior das ilhotas basalóides configurando o padrão misto deste tumor. Os espécimes apresentaram um alto índice mitótico. Detectou-se metástase linfonodais em cinco pacientes, em três deles com rompimento capsular. No período de seguimento de 6 a 22 meses, quatro pacientes desenvolveram metástase regional e um paciente apresentou recorrência tumoral local. Verificou-se cinco óbitos relacionados com a doença, após um período de 10 a 35 meses. EREÑO et al. $^{31}$, enfatizaram contrariamente a outros relatos, que o carcinoma escamoso basalóide não apresentou um comportamento mais agressivo que o carcinoma espinocelular.

A revisão das características clínico-patológicas do carcinoma escamoso basalóide na região de cabeça e pescoço, foram descritas nos trabalhos de BARNES et al. ${ }^{14}$, FERLITO et al. $^{32}$ e FERLITO; DEVANEY; RINALDO ${ }^{33}$, em 1996. Os autores enfatizaram a importância do diagnóstico diferencial com o carcinoma adenóide cístico, carcinoma adenoescamoso, carcinoma mucoepidermóide, carcinoma neuroendócrino de pequenas células, com o adenocarcinoma de células basais, adenocarcinomas metastáticos, carcinoma espinocelular, carcinoma de células fusiformes e com o carcinoma adenóide de células escamosas e com o melanoma. 
Uma análise retrospectiva de tumores diagnosticados como carcinoma adenóide cístico, carcinoma espinocelular pouco diferenciado, carcinoma indiferenciado e carcinoma neuroendócrino da cabeça e pescoço foi realizada por FERLITO et al. ${ }^{34}$, em 1997, onde foram detectados 15 carcinomas escamosos basalóides localizados na laringe e hipofaringe, em estádios clínicos avançados. O tratamento empregado em 12 pacientes foi o cirúrgico com esvaziamento cervical; a radioterapia pré-operatória foi utilizada em dois pacientes e a radioterapia pós-operatória em oito pacientes. Apenas três pacientes foram submetidos à quimioterapia complementar. Detectou-se inicialmente a presença de metástase regional em oito pacientes. Metástases a distância foram encontradas em nove pacientes, sendo os órgãos acometidos os pulmões predominantemente, o fígado, os ossos e o cérebro. Em três pacientes verificou-se recorrência local do tumor. Três pacientes com carcinoma na laringe e seis pacientes que apresentaram carcinoma na hipofaringe foram a óbito pela doença, dois pacientes apresentaram-se vivos com a doença e dois livres da doença. Estimou-se para os pacientes, uma taxa de sobrevida global em cinco anos de 17,5\%. Realizou-se a análise imuno-histoquímica para as citoqueratinas AE1/AE3, CAM 5.2., EMA, CEA, vimentina, proteína S-100, actina, colágeno IV, EGF. Avaliou-se também a expressão dos marcadores MIB-1, Ki-67, cromogranina, sinaptofisina e c-erbB-2. Os autores consideraram que as células basalóides são originárias das células totipotentes. Caracterizou-se também o carcinoma escamoso basalóide da laringe e hipofaringe como uma entidade morfológica distinta, com comportamento biológico agressivo, promotora de metástases regional e a distância precoces e com prognóstico pior que do carcinoma espinocelular convencional.

Nove espécimes de carcinoma escamoso basalóide localizados no trato aero-digestivo superior, supraglote, hipofaringe e base de língua, foram analisados clínica e imuno- 
histoquímicamente por KIM et al. ${ }^{57}$, em 1998. Este estudo retrospectivo abrangeu a análise de 237 casos de carcinoma de laringe ressecados cirurgicamente durante um período de 13 anos. Ao início do tratamento cinco pacientes apresentaram metástase regional. Após um período médio de seguimento de 18,2 meses, dois pacientes foram a óbito devido à metástase pulmonar. As marcações imuno-histoquímicas para citoqueratinas de alto (34ßE12) e baixo (35ßH11) pesos moleculares apresentaram padrões de marcação irregulares. Para a proteína Bcl-2 as marcações foram negativas em todos os espécimes, do mesmo modo aos marcadores neuroendócrinos, os resultados foram negativos. Sugeriu-se uma distinta diferenciação das células basalóides, comparativamente às células do carcinoma espinocelular convenional, enfatizando a pequena possibilidade do carcinoma escamoso basalóide ser oriundo das células basais do epitélio de revestimento.

WIENEKE; THOMPSON; WENING ${ }^{133}$, em 1999, analisaram as características clínico-patológicas de 14 pacientes com carcinomas escamosos basalóides localizados no trato sinonasal. O tratamento empregado em 13 pacientes foi o cirúrgico com radioterapia adjuvante em cinco pacientes e quimioterapia em dois, sendo esta última sugerida em casos de metástases comprovadas. Oito pacientes apresentaram recorrência local ou persistência do tumor. Verificou-se a ocorrência de metástases em cinco pacientes, envolvendo ossos, pulmões e cérebro. Microscopicamente, o carcinoma escamoso basalóide caracterizou-se pelo predomínio de células basalóides com configuração predominantemente lobular ou sólida, porém, apresentando também outros padrões como o trabecular, cribiforme, glandular-like e tubular. Após cinco anos de seguimento, $50 \%$ dos pacientes foram a óbito em decorrência da doença, três pacientes apresentavam-se vivos com câncer, um paciente morreu assintomático e dois pacientes estavam vivos sem a doença. O período mediano de sobrevida foi de 12 
meses. Considerou-se, a partir das características clínicas, o carcinoma escamoso basalóide do trato sinonasal como um tumor de alta morbidade e mortalidade. Concluiu-se que, o carcinoma escamoso basalóide localizado no trato sinonasal caracteriza-se por um comportamento agressivo, apresentando-se em estádios clínicos avançados no momento diagnóstico, inclusive com invasão tumoral multifocal. Os pacientes geralmente apresentam quadros de metástases regional e a distância, bem como uma pequena taxa de sobrevida .

Vinte carcinomas escamosos basalóides da região da cabeça e pescoço foram identificados por PAULINO et al. ${ }^{92}$, em 2000, em um estudo retrospectivo de 1975 a 1997. Os sítios acometidos em ordem decrescente de freqüência foram laringe (4), língua (3), seio piriforme (3), nariz (2), soalho da boca (2), região do músculo mastóide (1), tonsila palatina (1), epiglote (1), nasofaringe (1), traquéia (1) e palato(1). Em 13 pacientes o tratamento adotado foi o cirúrgico; nove pacientes receberam radioterapia adjuvante e em dois pacientes foi utilizada a radioterapia exclusiva. Dois pacientes receberam apenas tratamento quimioterápico e a combinação radioterapia e quimioterapia foi utilizada em dois pacientes. $\mathrm{O}$ período de acompanhamento variou de nove meses a oito anos. Onze pacientes apresentaramse vivos e livres de doença por um período de seguimento de dois anos. Após um período de oito anos, um paciente apresentou-se vivo e livre de doença e quatro pacientes apresentaramse vivos com a doença. Cinco pacientes desenvolveram metástases em linfonodos regionais e um paciente apresentou metástase pulmonar, todos estes seis pacientes foram a óbito. Segundo PAULINO et al. ${ }^{92}$, o carcinoma escamoso basalóide caracteriza-se por um comportamento agressivo, sendo conveniente o emprego de modalidades terapêuticas conjuntas. Permaneceu porém a dúvida quanto aos fatores associados ao prognóstico desfavorável desta variante e se realmente o padrão microscópico característico é um fator 
prognóstico, uma vez que os tumores são geralmente detectados em estádios clínicos avançados.

BRACERO et al. ${ }^{17}$, em 2000, analisaram 272 espécimes de carcinoma espinocelular da laringe e hipofaringe e detectaram seis espécimes que exibiram os critérios microscópicos propostos por WAIN et al. ${ }^{131}$, para o diagnóstico do carcinoma escamoso basalóide. O tratamento utilizado foi o cirúrgico, complementado por radioterapia em apenas dois pacientes. Após um período de seguimento de 42 a 142 meses, verificou-se que os pacientes estavam vivos livres de doença. Ressaltou-se o estádio clínico inicial e a ausência de metástase regional nos pacientes acometidos no momento do diagnóstico, sendo a agressividade do carcinoma escamoso basalóide atribuída ao perfil biológico primitivo das células basalóides. 


\subsection{Carcinoma Escamoso Basalóide na Mucosa Bucal}

O carcinoma escamoso basalóide na mucosa bucal foi relatado pela primeira vez por CADIER et al. $^{21}$, em 1992, ampliando o conhecimento dos sítios da cabeça e pescoço acometidos por esta neoplasia maligna. A paciente do gênero feminino, 83 anos, sem história de consumo de álcool e tabaco, apresentou lesão nodular e ulcerada na mucosa jugal, sem evidências clínicas de acometimento do tecido cutâneo, do nervo facial e de metástases nos linfonodos regionais. O diagnóstico clínico foi de carcinoma espinocelular. A partir da biópsia incisional estabeleceu-se o diagnóstico inicial de carcinoma adenóide cístico. Posteriormente, efetuou-se uma revisão dos espécimes estabelecendo-se o diagnóstico de carcinoma escamoso basalóide, confirmado pela análise microscópica da peça cirúrgica. Os critérios microscópicos para o diagnóstico de carcinoma escamoso basalóide utilizados foram os propostos por WAIN et al. ${ }^{131}$, em 1986. O tratamento empregado foi o cirúrgico, sem a utilização de radioterapia e quimioterapia complementares. Após o período de um ano, a paciente encontrava-se sem evidências clínicas de recorrência tumoral. A composição do carcinoma escamoso basalóide por células fenotipicamente distintas pode conduzir ao diagnóstico equivocado como o ocorrido no início deste relato. Os autores ressaltaram a necessidade da diferenciação do carcinoma escamoso basalóide na mucosa bucal, principalmente com o carcinoma adenóide cístico, variante sólida e também com o carcinoma adenoescamoso e com o carcinoma basoescamoso da pele.

Outras lesões isoladas em boca do carcinoma escamoso basalóide foram descritas no palato $^{73,43}$, na mucosa jugal ${ }^{9}$, no soalho bucal ${ }^{22}$ e na tuberosidade maxilar ${ }^{132}$. Estes trabalhos ressaltaram que os diferentes fenótipos das células constituintes do carcinoma escamoso basalóide geram dúvidas diagnósticas sendo importante o diagnóstico diferencial com o 
carcinoma adenóide cístico, carcinoma espinocelular, adenocarcinoma de células basais e carcinoma neuroendócrino. O carcinoma escamoso basalóide segundo os relatos acima caracterizou-se por um comportamento biológico agressivo, delineado por um alto índice mitótico, pela invasão perineural e pelo comprometimento metastático linfonodal, promotores de um pobre prognóstico.

Um aspecto clínico peculiar do carcinoma escamoso basalóide na boca foi ressaltado por IDE et al. ${ }^{50}$, em 1996. O tumor localizava-se no terço posterior da borda da língua e apresentava aspecto polipóide, pediculado e ulcerado, sem evidências clínicas de invasão tumoral nos tecidos adjacentes. Uma característica bastante peculiar, observada na peça cirúrgica, foi a distribuição tumoral restrita ao pólipo, não ultrapassando seu pedículo e não atingindo a base da lesão. As características preponderantes ao prognóstico favorável neste caso foram a localização superficial e o padrão de crescimento exofitico da neoplasia.

A presença de metástase na boca do carcinoma escamoso basalóide localizado primariamente no esôfago também foi descrito por IDE et al. ${ }^{51}$, em 1997. O paciente do gênero masculino apresentou uma lesão na face lingual do rebordo alveolar inferior, na região de molares, pediculada e de aspecto granuloso. Ao exame clínico não se observou linfadenopatia regional e ao radiográfico não se verificou a presença de osteólise mandibular, reforçando a possibilidade de um quadro metastático. Decorrido um mês o paciente foi a óbito por recorrência tumoral, caracterizando o prognóstico desfavorável das metástases bucais.

Em 1997, WEDENBERG et al. ${ }^{132}$ descreveram um carcinoma escamoso basalóide localizado na tuberosidade maxilar com aspecto clínico de placa e invasão intra-óssea de aspecto cístico. O paciente, com 55 anos de idade, tabagista, foi submetido exclusivamente à cirurgia como tratamento. O espécime apresentou os critérios morfológicos propostos por 
WAIN et al. ${ }^{131}$, diferindo na ausência de pérolas córneas e na menor proporção do número de mitoses. Descartou-se o diagnóstico de carcinoma adenóide cístico, carcinoma neuroendócrino, carcinoma de pequenas células, adenocarcinoma de células basais e carcinoma adenoescamoso. Realizou-se o diagnóstico diferencial também com o ameloblastoma do tipo basalóide. A continuidade do tumor com epitélio de revestimento e a associação das células basalóides com o componente escamoso foram pertinentes à sua diferenciação. As marcações imuno-histoquímicas realizadas apresentaram intensa marcação em mais de $75 \%$ das células para citoqueratinas 10,17-18 e moderada positividade a proteína p53. A imunorreatividade a proteína Bcl-2 também foi moderada, porém com extensão em mais de $75 \%$ das células. O número de mitoses apresentou-se baixo e a marcação pelo anticorpo Ki-67 embora intensa, apresentou uma pequena extensão de células neoplásicas positivas, quadro indicativo de um baixo índice proliferativo. Verificou-se marcação negativa para a proteína c-erbB-2, vimentina e proteína S-100. A análise deste painel sugeriu que este carcinoma escamoso basalóide localizado na mandíbula, apresentava um baixo grau de malignidade, direcionando a terapia pouco invasiva empregada.

A análise do comportamento biológico das células basalóides foi realizado por ABIKO et al. $^{2}$, em 1997, a partir da cultura de células provenientes de um carcinoma escamoso basalóide localizado no soalho bucal, sugerindo um modelo de estudo para as estratégias terapêuticas e para a avaliação prognóstica. O perfil imuno-histoquímico das células basalóides, evidenciaram positividade para citoqueratinas de baixo peso molecular e para EMA (antígeno membrana epitelial) sugerindo a natureza epitelial destas células. Detectou-se também em poucas células uma fraca positividade para vimentina. Os resultados foram negativos para actina muscular e proteína S-100. Características como proliferação 
celular, potencial de invasão e migração foram analisados comparativamente a clones de células de carcinoma espinocelular de alto e baixo potencial de invasão. As células do carcinoma escamoso basalóide apresentaram alta atividade proliferativa e intenso potencial de invasão, resultados estes, semelhantes aos das células escamosas de alto potencial invasivo do carcinoma espinocelular pouco diferenciado. O índice de migração das células basalóides foi maior que o das células escamosas de baixo grau e menor que o das células de alto grau de invasão. Estes resultados permitiram estabelecer que as células basalóides possuem alto poder de invasão sendo responsáveis por uma maior produção enzimática devido a sua maior capacidade proliferativa.

Também BABÓ et al. ${ }^{10}$, em 1998, analisaram a partir de clones de células transplantadas no subcutâneo e na mucosa bucal de hospedeiro imunossuprimido, o comportamento biológico de células tumorais fenotipicamente distintas, componentes de tumores mistos como o carcinoma escamoso basalóide. O espécime doador foi proveniente de um carcinoma escamoso basalóide localizado na mucosa bucal de paciente do gênero feminino, de 60 anos de idade. A histogênese do tumor foi delineada a partir da microscopia eletrônica e de marcações imuno-histoquímicas, revelando as características epiteliais das células tumorais, não suscitando dúvidas quanto à origem dos dois componentes celulares do carcinoma escamoso basalóide nas células totipotentes primitivas, as quais possuem habilidade para gerar células com fenótipos distintos. A atividade proliferativa das células basalóides foi maior quando comparado ao das células escamosas, que apresentaram um comportamento mais invasivo. Concluiu-se que, ambos componentes basalóide e escamoso contribuíram para o comportamento agressivo do carcinoma escamoso basalóide, sendo pouco 
provável que apenas a atividade do componente basalóide seja crítica, uma vez que este estudo não demonstrou uma relação percentual entre os dois componentes presentes no tumor.

Algumas características relacionadas à progressão tumoral maligna, incluindo a proliferação celular, ploidia nuclear, atividade da colagenase tipo IV foram analisadas comparativamente por BABÓ; BOSCI; JENEY ${ }^{11}$, em 1999, em populações de células basalóides e escamosas de carcinoma escamoso basalóide xenotransplantado em mucosa bucal e em tecido subcutâneo. O componente basalóide apresentou um crescimento avançado no tecido subcutâneo, composto por 69,3\% de células aneuplóides, não evidenciando sinais de invasão tumoral. O transplante deste tumor para a mucosa bucal resultou no ressurgimento da população de células escamosas, constituída equivalentemente por células aneuplóides e diplóides. As células diplóides tumorais presentes no tecido subcutâneo apresentaram-se na fase G1 do ciclo celular e 30\% das células tumorais aneuplóides e diplóides da mucosa bucal apresentaram-se nas fases G2 e S. O tumor da mucosa bucal composto por uma população mista, apresentou uma produção da colagenases tipo IV, indicando o seu alto potencial infiltrativo. Concluiu-se que, a atividade proliferativa do carcinoma escamoso basalóide sofreu influências diretas de fatores locais associados às subpopulações de células tumorais, favorecendo a proliferação de células basalóides aneuplóides como observado no subcutâneo de camundongos imunossuprimidos ou de células escamosas diplóides de baixa atividade proliferativa e alto potencial invasivo. A agressividade biológica do carcinoma escamoso basalóide associou-se àsua heterogeneidade celular, expressada pelos diferentes fenótipos. As células basalóides caracterizaram-se pela rápida proliferação tumoral enquanto as células escamosas provinham condições para a invasão tumoral pela alta produção da colagenases tipo IV. 
A análise imuno-histoquímica de cinco carcinomas escamosos basalóides ocorridos em um período de três anos, foram relatados por ALTAVILLA et al. ${ }^{7}$, em 1999. Todos os pacientes eram do gênero masculino, com idades entre 50 e 75 anos, história de consumo de álcool e tabaco, apresentando lesões exofíticas e ulceradas na boca e orofaringe. Os pacientes apresentaram estádio clínico III (TNM) ${ }^{122}$ em $60 \%$ dos casos. Apenas metástases em linfonodos regionais foram detectadas. Realizaram-se a ressecção cirúrgica do tumor e a radioterapia complementar, sendo um paciente submetido apenas à radioterapia e quimioterapia. Registrou-se um óbito pela doença após 32 meses e três pacientes livres da doença, após um período de 10 a 48 meses de acompanhamento. O diagnóstico anterior de carcinoma espinocelular foi realizado em $60 \%$ dos casos e de carcinoma adenóide cístico em 20\%. Microscopicamente, o tumor apresentou os critérios de WAIN et al. ${ }^{131}$ com presença da associação do componente basalóide com o carcinoma espinocelular, ora in situ ora invasivo. A invasão tumoral nos linfonodos exibiu um padrão basalóide. As marcações imunohistoquímicas revelaram componente basalóide positivo exibindo marcação difusa para citoqueratinas AE1/AE3, CAM 5.2, o mesmo padrão de marcação foi observado para vimentina. As células basalóides foram negativas para proteína S-100 e para o marcador cromogranina, excluindo-se a possibilidade de carcinoma neuroendócrino. A partir da análise destes cinco casos, ALTAVILLA et al. ${ }^{7}$ sugeriram que o carcinoma escamoso basalóide freqüentemente é detectado em estádios clínicos avançados, podendo apresentar um comportamento agressivo caracterizado por ser localmente invasivo e gerar metástases regional e a distância. 


\subsection{Carcinoma Escamoso Basalóide X Carcinoma Espinocelular}

Poucos trabalhos na literatura compararam as características clínicas, microscópicas e o prognóstico do carcinoma escamoso basalóide e do carcinoma espinocelular como pode ser observado na Tabela 1. Destes, apenas três estudos foram realizados com amostras de carcinoma escamoso basalóide primários em boca.

TABELA 1 - Análise comparativa do carcinoma escamoso basalóide e do carcinoma espinocelular, segundo localização e evolução clínica

\begin{tabular}{|c|c|c|c|c|}
\hline Autores & Localização & CEB & CEC & Evolução \\
\hline Luna et al. ${ }^{74}(1990)$ & Trato aero-digestivo & 6 & 47 & Similar \\
\hline Coppola et al. ${ }^{26}(1993)$ & Boca (soalho bucal) & 8 & 63 & CEB pior \\
\hline Moro et al. ${ }^{79}$ (1994) & Pulmão & 37 & 40 & CEB pior \\
\hline Sarbia et al. ${ }^{100}$ (1997) & Esôfago & 17 & 133 & Similar \\
\hline Koide et al. ${ }^{60}(1997)$ & Esôfago & 4 & 42 & Similar \\
\hline Abiko et al. ${ }^{3}(1998)$ & Boca (soalho + gengiva) & 2 & 10 & CEB pior \\
\hline Winzenburg et al. ${ }^{134}(1998)$ & Cabeça e pescoço & 26 & 23 & CEB pior \\
\hline Lam et al. ${ }^{66}(2001)$ & Esôfago & 30 & 335 & Similar \\
\hline Coletta et al. ${ }^{24}$ (2001) & Boca (mucosa jugal) & 2 & 2 & CEB pior \\
\hline
\end{tabular}

CEB: Carcinoma Escamoso Basalóide, CEC: Carcinoma Espinocelular 
Uma análise comparativa do comportamento clínico do carcinoma escamoso basalóide e do carcinoma espinocelular convencional foi realizada por LUNA et al. ${ }^{74}$, em 1990, utilizando-se de dados clínico-patológicos, da avaliação da ploidia e da análise da capacidade proliferativa tumoral de espécimes de ambos grupos. Nove carcinomas escamosos basalóides foram detectados nos arquivos do "Cancer Center" da Universidade do Texas em um período 1974 a 1984. Quanto à localização, em sete pacientes o tumor encontrava-se na hipofaringe, em cinco no seio piriforme, em dois na parede da faringe e em dois pacientes na base da língua. Verificou-se que os pacientes apresentavam-se em estádios clínicos avançados (III e IV).O tratamento consistiu na ressecção cirúrgica do tumor, com dissecção de linfonodos regionais em sete pacientes; oito pacientes receberam radioterapia complementar. Sete pacientes desenvolveram metástases a distância, localizadas principalmente nos pulmões, no fígado e em múltiplos sítios. Ao final do acompanhamento, num período médio de 25,6 meses, todos os pacientes foram a óbito, seis por conseqüência do tumor. Comparativamente ao carcinoma espinocelular com localização e estádios clínicos equivalentes, os pacientes com carcinoma escamoso basalóide nos estádio III e IV apresentaram metástase regional no início do tratamento em $83,3 \%$ e nos pacientes com carcinoma espinocelular este valor foi de 74,4\%. O índice de metástases a distância nos pacientes com carcinoma escamoso basalóide foi de $66,6 \%$ e no carcinoma espinocelular $65,9 \%$. Num período de 48 meses, $50 \%$ dos pacientes com carcinoma escamoso basalóide e 55,3\% dos pacientes com carcinoma espinocelular foram a óbito. A média de sobrevida, a partir do início do tratamento, foi de 23 meses para os pacientes com carcinoma escamoso basalóide e para os pacientes com carcinoma espinocelular, de 21 meses. Sugeriu-se como tratamento para o carcinoma escamoso basalóide cirurgia e radioterapia pós-operatória, utilizando-se também a quimioterapia complementar, devido à alta incidência de metástases a distância. Concluiu-se 
que, pacientes com carcinoma escamoso basalóide e com carcinoma espinocelular com estádio clínico, localização anatômica e tratamentos equivalentes possuem um curso biológico e um comportamento clínico semelhantes.

As características clínico-patológicas e o perfil imuno-histoquímico de oito pacientes com carcinoma escamoso basalóide localizados no soalho bucal foram descritos por COPPOLA et al. ${ }^{26}$, em 1993. O comportamento clínico e a probabilidade de sobrevida dos pacientes com carcinoma escamoso basalóide foram analisados, comparativamente, a um grupo constituído por 63 pacientes com carcinoma espinocelular com localização equivalente. Os pacientes acometidos pelo carcinoma escamoso basalóide apresentavam idade média de 52 anos, cinco eram do gênero masculino, seis pacientes eram tabagistas e etilistas. Três pacientes apresentavam estádio clínico IV, quatro estádio clínico III e um paciente estádio clínico II. Microscopicamente, os oito espécimes apresentaram os critérios descritos por WAIN et al. ${ }^{131}$. O componente escamoso apresentou-se como carcinoma espinocelular moderadamente diferenciado, e em alguns casos, sobrejacente ao componente basalóide visualizaram-se focos de carcinoma in situ. Quanto à histogênese, considerou-se o carcinoma escamoso basalóide uma variante do carcinoma espinocelular, proveniente de células primitivas totipotentes. O componente basalóide, em seis espécimes, totalizou 60 a $80 \%$ do tumor, em dois espécimes representou mais de 50\% do tumor. Dentre os parâmetros prognósticos avaliados no carcinoma escamoso basalóide e no carcinoma espinocelular do soalho bucal, invasão perineural e metástases em linfonodos regionais foram observadas em 75\% dos pacientes com carcinoma escamoso basalóide. A atividade mitótica do carcinoma escamoso basalóide foi maior comparativamente a do carcinoma espinocelular bem diferenciado e similar a do carcinoma espinocelular moderado a pouco diferenciado. A 
recorrência local e as metástases a distância do carcinoma escamoso basalóide, comparativamente, ao carcinoma espinocelular foram maiores, porém a incidência de metástase regional não apresentou diferença significativa. COPPOLA et al. ${ }^{26}$ concluíram que, o carcinoma escamoso basalóide apresentou comparativamente ao carcinoma espinocelular, independentemente do grau de diferenciação deste último, um comportamento biológico agressivo e um prognóstico pior, caracterizado pelo alto índice de recorrências e metástases.

As características clínicas e a taxa de sobrevida de 37 pacientes portadores de carcinoma escamoso basalóide foram analisadas comparativamente a 40 pacientes com carcinoma espinocelular pouco diferenciado localizados nos pulmões por MORO et al. ${ }^{79}$, em 1994. Microscopicamente, 18 carcinomas escamosos basalóides apresentavam apenas o componente basalóide; em 19 espécimes o padrão era misto com pelo menos $60 \%$ de presença deste componente. Os pacientes apresentaram, predominantemente, estádios clínicos I e II. A ressecção cirúrgica do tumor foi acompanhada de radioterapia em 15 pacientes com carcinoma escamoso basalóide e em 17 pacientes com carcinoma espinocelular. A quimioterapia como tratamento complementar foi realizada em três pacientes. A taxa de sobrevida acumulada em cinco anos para os pacientes com carcinoma escamoso basalóide foi de $15 \%$ e de $47 \%$ para os pacientes com carcinoma espinocelular, ambos apresentando estádios clínicos I e II. Concluiu-se que o carcinoma escamoso basalóide, dentre os carcinomas pulmonares não pertencentes à categoria dos carcinomas de pequenas células, apresenta um comportamento mais agressivo, com um pior prognóstico.

A caracterização clínica e microscópica do carcinoma escamoso basalóide localizado no esôfago, bem como a análise comparativa do seu prognóstico com o carcinoma espinocelular, foram realizadas por SARBIA et al. ${ }^{100}$, em 1997, a partir de 17 espécimes de 
carcinoma escamoso basalóide e 133 de carcinoma espinocelular. Foram excluídos do estudo pacientes que realizaram tratamento radio e/ou quimioterápico prévios, pacientes com tumores recorrentes e com evidência de metástases. Clinicamente, os pacientes do gênero masculino foram predominantemente acometidos por ambos tumores com uma pequena variação entre as médias de idades. Microscopicamente, os espécimes de carcinoma escamoso basalóide apresentaram predomínio do padrão sólido, sendo freqüente a presença de comedonecrose e hialinização do estroma circunvizinho às ilhotas basalóides. Focos de diferenciação escamosa foram observados em 29,4\% dos carcinomas escamosos basalóides, sendo a displasia severa e o carcinoma in situ, presente em 70,6\%. Dados da microscopia eletrônica evidenciaram ausência de grânulos secretores e também de diferenciação escamosa. O índice de proliferação verificado pela marcação com o anticorpo MIB-1 foi mais alto para o carcinoma escamoso basalóide em relação ao carcinoma espinocelular. Os índices mitótico e apoptótico do carcinoma escamoso basalóide foram maiores que os observados no carcinoma espinocelular, porém estas diferenças não apresentaram significancia estatística. A análise da taxa de sobrevida dos pacientes também não apresentou diferença estatística. Concluiu-se, que o carcinoma escamoso basalóide é uma variante distinta do carcinoma espinocelular podendo ser diferenciada do ponto de vista morfológico e imuno-histoquímico do carcinoma adenóide cístico e do carcinoma de pequenas células. Em consideração ao pobre grau de diferenciação e o alto índice proliferativo, o prognóstico dos pacientes com carcinoma escamoso basalóide e com carcinoma espinocelular no esôfago não diferiram entre si.

O valor prognóstico da imunomarcação pela proteína Bcl-2 e a análise das taxas de sobrevida de pacientes acometidos pelo carcinoma escamoso basalóide e pelo carcinoma espinocelular no esôfago foram avaliados, comparativamente, por KOIDE et al. ${ }^{60}$, em 1997. 
Quarenta e dois carcinomas espinocelulares subdivididos em bem diferenciados (17), moderadamente diferenciados (16) e pouco diferenciados (9) foram comparados a quatro carcinomas escamosos basalóides. A expressão intensa da proteína Bcl-2 foi evidenciada em $100 \%$ dos carcinomas escamosos basalóides. Nos carcinomas espinocelulares pouco diferenciados a positividade para Bcl-2 foi verificada em apenas 22,2\% dos espécimes, com uma marcação fraca e presente em menos de $10 \%$ do fragmento tumoral. A expressão da proteína Bcl-2 nos carcinomas espinocelulares apresentou apenas associação ao processo da apoptose, não estando associada à progressão tumoral, à presença de linfonodos positivos e à taxa de sobrevida. Nos carcinomas escamosos basalóides, a forte expressão da proteína Bcl-2 apresentou associação com a supressão do apoptose e com a progressão tumoral agressiva, embora três pacientes não tenham apresentado recorrência tumoral. Não foi detectada diferença quanto à probabilidade de sobrevida acumulada em cinco anos para os pacientes com carcinoma escamoso basalóide e com carcinoma espinocelular, bem como para as marcações positiva ou negativa para a proteína Bcl-2.

ABIKO et al. ${ }^{3}$, em 1998 analisaram comparativamente, a partir da descrição clínicopatológica, dois carcinomas escamosos basalóides com dez carcinomas espinocelulares na mucosa bucal. Em um dos pacientes a lesão apresentou-se ulcerada e localizada no soalho bucal, tendo sido diagnosticada inicialmente como carcinoma espinocelular pouco diferenciado. Realizou-se a ressecção cirúrgica e a dissecção dos linfonodos regionais. O diagnóstico estabelecido foi de carcinoma escamoso basalóide sem evidências de metástase regional. Após três anos de acompanhamento, o paciente apresentou-se livre de doença. O segundo paciente apresentou lesão ulcerada na gengiva, na região de pré-molares e molares, sendo este o primeiro relato de um o carcinoma escamoso basalóide primário na gengiva. 
Realizou-se a ressecção parcial da mandíbula e dois anos mais tarde, a paciente apresentou-se livre de doença. Microscopicamente, os dois espécimes caracterizaram-se pela proliferação celular sólida, com configuração lobular, com células periféricas dispostas em paliçada e associação com áreas de diferenciação escamosa. Algumas características como necrose central por coagulação nas ilhotas, pseudolumes com conteúdos positivos a PAS e Alcian blue, hialinização do estroma, alto número de mitoses e invasão vascular, perineural e óssea foram observados nos dois espécimes analisados. Segundo os autores o diagnóstico diferencial do carcinoma escamoso basalóide em boca deve incluir, particularmente, o carcinoma espinocelular pouco diferenciado e o ameloblastoma maligno. As marcações imuno-histoquímicas revelaram uma forte expressão da citoqueratina de baixo peso molecular AE-1 no componente basalóide e baixa positividade à citoqueratina de alto peso molecular AE-3 nas células escamosas. Marcações para vimentina e actina muscular e proteína S-100 foram negativas nas ilhotas tumorais. Descartou-se nestes espécimes analisados a hipótese de diferenciação glandular das células totipotentes precursoras deste tumor. $O$ número de AgNOR por núcleo foi mais alto no carcinoma escamoso basalóide. Os autores sugeriram um comportamento mais agressivo do carcinoma escamoso basalóide, delineado por um prognóstico mais desfavorável, comparativamente ao carcinoma espinocelular.

WINZENBURG et al. ${ }^{134}$, em 1998, analisaram comparativamente o comportamento clínico e a associação das características morfológicas de 26 espécimes de carcinoma escamoso basalóide da cabeça e pescoço, subdivididos em dois grupos. Grupo 1, 21 espécimes compostos por mais de $90 \%$ do componente basalóide e o grupo 2, cinco espécimes com um padrão misto, basalóide associado ao componente escamoso. Analisou-se também a evolução dos pacientes com carcinoma escamoso basalóide comparativamente a 23 
pacientes com carcinoma espinocelular pouco diferenciado, considerando-se os estádios clínicos T e N no momento diagnóstico, metástases a distância, recorrência local e taxa de sobrevida. A análise dos parâmetros morfológicos, comedonecrose e hialinização do estroma apresentaram correlação com o prognóstico dos pacientes do grupo 2, considerando-se a maior incidência destas características neste grupo e o maior índice de recorrência local, metástases a distância e pequena taxa de sobrevida. Correlacionando invasão perilinfática e perivascular dos grupos 1 e 2 do carcinoma escamoso basalóide à taxa de sobrevida, observou-se maior número pacientes com metástases a distância no grupo 2, sugerindo um pior prognóstico. Embora detectadas variações no comportamento clínico dos grupos analisados, diferenças estatísticas significativas não foram observadas devido ao pequeno número das categorias analisadas. A comparação do curso clínico do carcinoma escamoso basalóide e do carcinoma espinocelular pouco diferenciado quanto a metástases a distância e taxas de sobrevida revelou um pior prognóstico para os pacientes com carcinoma escamoso basalóide. A comparação das taxas de sobrevida demonstrou uma média de 20,8 meses para os pacientes com carcinoma escamoso basalóide e 50,7 meses para os pacientes com carcinoma espinocelular pouco diferenciado. A presença de metástase em linfonodos regionais no momento diagnóstico esteve também diretamente relacionada à pequena taxa de sobrevida e principalmente a ocorrência precoce de metástases a distância observadas no carcinoma escamoso basalóide. Concluiu-se que o carcinoma escamoso basalóide, comparativamente ao carcinoma espinocelular pouco diferenciado, caracteriza-se por um comportamento clínico mais agressivo, caracterizado por um pior prognóstico. Sugeriu-se que, os pacientes com carcinoma escamoso basalóide não sejam incluídos em análises prospectivas de pacientes com carcinoma espinocelular. 
A atividade proliferativa e a expressão da proteína p53 em quatro carcinomas escamosos basalóides, foram descritas por AKYOL et al. ${ }^{6}$, em 1998. Os tumores localizavamse na laringe supraglótica e apresentavam estádio clínico T3-4. Os pacientes foram submetidos àlaringectomia total, com esvaziamento cervical e radioterapia pós-operatória. As marcações nucleares para a proteína p53 foram verificadas em três dos quatro espécimes. Um espécime apresentou $25 \%$ de positividade das células tumorais e os outros dois espécimes mais de $50 \%$ das células foram positivas. A expressão para PCNA foi alta e visualizada em todos os espécimes, com padrões de marcação distintos. Um espécime apresentou até $25 \%$ de células positivas, outro espécime de 25 a $50 \%$ de células positivas, e em dois espécimes, a positividade foi maior que $50 \%$. AKYOL et al. ${ }^{6}$, concluíram que o carcinoma escamoso basalóide apresenta um comportamento clínico agressivo, similar ao do carcinoma espinocelular de alto grau, caracterizados por uma atividade proliferativa e um índice de marcação a p53 semelhantes.

SARBIA et al. ${ }^{101}$, em 1999, analisaram os mecanismo envolvidos na ativação da proteína supressora da apoptose, Bcl-2, bastante evidenciada no carcinoma escamoso basalóide do esôfago. A expressão da proteína Bcl-2, bem como a cooperação do gene $c-m y c$ na tumorigênese do carcinoma escamoso basalóide foram analisadas, comparativamente, ao carcinoma espinocelular convencional do esôfago, utilizando-se 23 espécimes de cada tumor. Os resultados revelaram uma maior e mais intensa expressão da proteína Bcl-2 nos espécimes de carcinoma escamoso basalóide, (86,9\%), comparando-se aos 17,4\% dos espécimes positivos de carcinoma espinocelular. A amplificação do gene $c$-myc, analisada pela técnica da PCR, apresentou expressão duas vezes maior nos casos de carcinoma escamoso basalóide sem, contudo apresentar significância estatística. Sugeriu-se a partir destes resultados, uma 
atividade cooperativa entre os genes bcl-2 e c-myc no desenvolvimento do carcinoma escamoso basalóide.

Em um estudo retrospectivo de dez anos, revisados por LAM et al. ${ }^{66}$, em 2001, 30 carcinomas escamosos basalóides foram identificados dentre 756 carcinomas de esôfago. As características clínico-patológicas e imuno-histoquímicas do carcinoma escamoso basalóide foram comparadas ao do carcinoma espinocelular do esôfago. A média das células positivas para o anticorpo MIB-1 no carcinoma escamoso basalóide foi de 750 células, maior que no carcinoma espinocelular. A taxa de sobrevida acumulada em cinco anos foi de $12 \%$ dos pacientes com carcinoma escamoso basalóide, sendo que o período médio sobrevida de 26 meses não diferiu daquela verificada para os pacientes com carcinoma espinocelular. Metástases a distância foram detectadas em 53\% dos pacientes, sendo os pulmões e o fígado os sítios mais acometidos. LAM et al. ${ }^{66}$ concluíram que o carcinoma escamoso basalóide, embora represente uma variante distinta do carcinoma espinocelular, não apresenta um pior prognóstico.

Em continuidade à investigação das diferentes anormalidades moleculares na patogênese do carcinoma escamoso basalóide e do carcinoma espinocelular no esôfago, OWONIKOKO et al. ${ }^{90}$, em 2001, analisaram 23 espécimes de cada tumor, avaliando a perda da heterozigose dos genes $A P C, R B$ e $M C C$, a amplificação do gene $C D K 4$ e a expressão das proteínas $\mathrm{Rb}$ e p53. A freqüência da perda da heterozigose do gene $R B$ não apresentou diferença entre os dois tumores analisados e a perda da expressão da proteína RB, foi equivalente para os espécimes de carcinoma escamoso basalóide e carcinoma espinocelular. O acúmulo da proteína p53 foi verificado com maior frequiência nos espécimes de carcinoma escamoso basalóide e a amplificação do gene $C D K 4$, não foi detectada em nenhum dos 
espécimes tumorais. As alterações moleculares como a inativação simultânea dos genes $A P C$ e $M C C$, envolvidos com uma alta atividade proliferativa tumoral, foi mais freqüentemente observada no carcinoma escamoso basalóide. Estas características foram pouco esclarecedoras para a patogênese dos tumores analisados, entretanto, os autores sugeriram que os resultados acima podem delinear diferenças moleculares na patogenia do carcinoma escamoso basalóide e do carcinoma espinocelular.

COLETTA et al. ${ }^{24}$, em 2001, descreveram dois carcinomas escamosos basalóides na mucosa bucal e delinearam o seu comportamento biológico a partir da análise de fatores associados ao potencial de invasão e proliferação celular. Levando-se em consideração o discutido comportamento agressivo do carcinoma escamoso basalóide, dois pacientes com carcinoma espinocelular pouco diferenciados, pareados quanto ao gênero, idade e estádio clínico foram também avaliados. O primeiro carcinoma escamoso basalóide foi proveniente de um paciente do gênero masculino, 58 anos de idade, etilista e tabagista, com lesão exofítica e ulcerada na mucosa jugal e provável acometimento metastático de linfonodos submandibulares. O tratamento consistiu de radio e quimioterapia combinadas, o paciente foi a óbito 12 meses após o diagnóstico. O segundo paciente, do gênero feminino, 63 anos de idade, etilista e tabagista, apresentava queixa de disfagia e presença de lesão exofítica, granular e ulcerada na mucosa jugal, infiltrando trígono-retromolar e pilar amigdaliano direito, sem detecção de sinais clínicos de acometimento metastático de linfonodos. A paciente foi submetida à radioterapia, com regressão do tumor e desaparecimento da disfagia. Ambos espécimes apresentaram os critérios microscópicos sugeridos por WAIN et al. ${ }^{131}$, com um padrão bifásico, sendo o componente basalóide predominante. O componente escamoso definiu-se como um carcinoma espinocelular bem à moderadamente diferenciado. Avaliou-se 
a atividade proliferativa das células tumorais a partir da quantificação e distribuição de AgNOR e da análise imuno-histoquímica para PCNA e proteína p53. O número médio e a área de AgNOR por núcleo, bem como as marcações para PCNA e p53 foram maiores nos carcinomas escamosos basalóides. Observou-se correlação entre os índices de PCNA e p53. Os níveis de metaloproteinases, MMPs, MMP-1, MMP-2 e MMP-9 foram mensurados, pela RT-PCR e demonstraram alto nível de mRNA nos dois espécimes de carcinoma escamoso basalóide; sendo estatisticamente distintos. A alta atividade proliferativa avaliada pelos dois métodos empregados associada à alta expressão de p53 no carcinoma escamoso basalóide comparativamente aos carcinomas espinocelulares pouco diferenciados, foram indicativos de um comportamento biológico agressivo do CEB. Aliada a esta constatação, a alta expressão das MMPs nos espécimes de carcinoma escamoso basalóide demonstraram a intensa capacidade das células basalóides na produção destas enzimas, favorecendo a tumorigênese. Os autores concluíram que o carcinoma escamoso basalóide, comparativamente ao carcinoma espinocelular pouco diferenciado, apresentou comportamento biológico mais agressivo ${ }^{24,28}$.

COLETTA et al. $^{25}$, em 2002, analisaram comparativamente a expressão das citoqueratinas CK7, CK8, CK14, CK19, da vimentina, da proteína S-100, cromogranina, laminina e colágeno tipo IV em três carcinomas escamosos basalóides, três carcinomas adenóides císticos, um adenocarcinoma de células basais e em dois carcinomas espinocelulares, bem diferenciado e indiferenciado. Dentre as citoqueratinas analisadas, o subtipo CK14 se expressou em todas as células basalóides dos três espécimes de carcinoma escamoso basalóide. Os autores verificaram a expressão das citoqueratinas CK7 e CK19 nas células basalóides dos carcinomas adenóides císticos e das citoqueratinas CK7 e CK8 no adenocarcinoma de células basais, sugerindo a utilização destes marcadores no diagnóstico 
diferencial destes tumores. Os carcinomas escamosos basalóides apresentaram positividade a laminina e ao colágeno tipo IV nos espaços microcísticos entre as células basalóides, marcação não detectada nos carcinomas adenóides císticos e no adenocarcinoma de células basais. Segundo COLETTA et al. ${ }^{25}$, o painel imuno-histoquímico proposto pode auxiliar no diagnóstico diferencial do carcinoma escamoso basalóide e de outros tumores com aspecto morfológico similar. 


\subsection{Marcadores imuno-histoquímicos associados à proliferação celular e apoptose}

Os carcinomas em geral constituem-se de uma complexa e heterogênea população celular com diversas características biológicas que influenciam diretamente a evolução clínica dos tumores com localização, estádio clínico e tratamentos equivalentes ${ }^{113}$. A heterogeneidade da população celular tumoral deve ser considerada quando da busca de biomarcadores de valor prognóstico. O front de invasão tumoral nos carcinomas tem se tornado uma das áreas de maior interesse para análise semiquantitativa do tamanho, da profundidade, da invasão e da graduação histológica do tumor. A morfologia das células tumorais no front de invasão, quase sempre, difere das partes mais superficiais do tumor apresentando uma menor diferenciação das células neoplásicas e uma maior dissolução celular ${ }^{119}$. Assim sendo, estudos recentes ${ }^{20,119}$ comprovaram que a morfologia e as características moleculares na região do front de invasão dos carcinomas contém informações com maior valor prognóstico quando comparado as demais áreas do tumor.

A avaliação da mutação e da expressão de genes envolvidos na patogênese ou na progressão tumoral vem sendo utilizada nos últimos anos, evidenciando considerável valor prognóstico. A associação dos parâmetros clínicos e morfológicos com o padrão de invasão tumoral definidos pela análise de marcadores imuno-histoquímicos de proliferação celular, da expressão da proteína p53 e de outras proteínas relacionadas aos processos apoptóticos, tem permitido delinear melhor biologicamente a progressão tumoral bem como o prognóstico dos pacientes. Segundo BANKFALVI; PIFFKO $^{12}$, a expressão ou supressão de alguns biomarcadores pode inclusive delinear a resposta tumoral a terapias adjuvantes, predizendo sua eficácia. 
Alguns genes como o gene supressor de tumor p53, localizado no braço curto do cromossomo 17 e a proteína de 53 kilodaltons codificada por ele desempenham importantes funções no controle da proliferação celular e na apoptose. A proteína p53 selvagem ou natural tem uma meia-vida curta, de aproximadamente 20 minutos em células normais, não se acumulando em níveis detectáveis pela imuno-histoquímica. A função desta proteína reside na coordenação do processo de interrupção do ciclo celular e na indução da apoptose. A proteína p53 induz uma parada na fase G1 do ciclo celular, denominada ponto de checagem, permitindo que o DNA danificado seja reparado antes da duplicação celular, evitando assim que clones de célula se desenvolvam com o DNA degenerado, ou então, ativa os mecanismos da apoptose eliminando as células que contenham alteração de seu material genético. As altas concentrações de p53 nuclear mobilizam a defesa celular, determinando uma ação antiproliferativa, pelo impedimento da complementação do ciclo celular e também atua ativando outros genes à codificação de proteínas necessárias ao reparo do DNA alterado ou para a execução dos mecanismos da morte celular programada. Devido a isso o gene TP53 é comumente conhecido como o "guardião do genoma" 67,69,87,116.

As mutações e/ou deleções do gene TP53 alteram a codificação e a atividade da proteína p53, permitindo a duplicação de erros genéticos, inclusive com a permissão da passagem do DNA lesado pela fase $\mathrm{S}$ do ciclo celular ${ }^{69}$. Estes danos genéticos do DNA, presentes nas células neoplásicas ocasionam um acúmulo da proteína p53, freqüentemente detectada pela técnica imuno-histoquímica.

As mutações do gene TP53 estão presentes em aproximadamente $100 \%$ dos carcinomas espinocelulares da cabeça e pescoço ${ }^{64}$ e sua participação na tumorigênese, bem como seu valor prognóstico, são exaustivamente estudados, principalmente pela detecção do 
acúmulo da proteína correspondente e pela acessibilidade à técnica imuno-histoquímica. $\mathrm{O}$ valor da expressão da proteína p53 tem sido avaliado não como um parâmetro isolado, mas sim como integrante de um painel de fatores que buscam o esclarecimento da biologia tumoral inclusive da resposta as terapias empregadas ${ }^{12,61,85,86,87,108}$. Entre os parâmetros utilizados neste painel, verifica-se a combinação da expressão da proteína p53 com: a morfologia tumoral, a proliferação celular, as proteínas reguladoras dos pontos de checagem durante o ciclo celular como a ciclina D1, cdk4, p21, p27, mdm2, pRb 4 49,49,55,61,65,70,82,91,103,121 e com as proteínas reguladoras dos processos apoptóticos ${ }^{77,78,106}$.

A proteína p53 controla o ciclo celular via regulação de várias proteínas, inclusive as proteínas da família Bcl-2 que regula a apoptose. A proteína Bax caracteriza-se por ser o membro da família Bcl-2 que apresenta uma correlação direta com o estímulo pró-apoptótico de p53, contrariamente, sua homóloga Bcl-2 apresenta sua sintetização suprimida aos estímulos equivalentes de $\mathrm{p} 53^{77,78,106}$. Alguns estudos, no entanto, não conseguiram demonstrar a correlação entre a expressão da proteína p53 e das proteínas Bcl-2 e Bax em carcinomas espinocelulares da cabeça e pescoço, especialmente na boca ${ }^{93,102,103,116,135}$.

Porém os altos índices de mutações do gene TP53 e de alterações na expressão da sua proteína, associados aos carcinomas espinocelulares da cabeça e pescoço, particularmente da mucosa bucal, contrastam com a falta de correlação com outros fatores prognósticos como estadiamento clínico e graduação histológica do tumor, não apresentando valor quanto à análise da sobrevida destes pacientes, na maioria dos trabalhos publicados $^{40,41,46,49,55,59,82,89,93,111}$.

Todavia, em alguns trabalhos como o de TSUJI et al. ${ }^{126}$, em 1995, o acúmulo e a conseqüente expressão da proteína p53 foi associada com um prognóstico desfavorável para 
os pacientes com carcinoma espinocelular de boca. Os pacientes com marcações negativas a esta proteína apresentaram uma probabilidade de sobrevida global acumulada em cinco anos de $69,7 \%$, enquanto pacientes p53-positivos apresentaram uma probabilidade de sobrevida igual a $39 \%(p<0,01)$.

Também GIROD et al. ${ }^{39}$, em 1998, demonstraram a partir de 133 pacientes com carcinoma espinocelular de boca uma associação significativa entre a alta expressão da proteína p53 e um prognóstico desfavorável. Estes autores analisaram também quanto ao prognóstico dos pacientes com carcinoma espinocelular de boca, a relação entre a expressão desta proteína e a atividade proliferativa tumoral, avaliada pelos anticorpos Ki-67 e PCNA. A probabilidade de sobrevida global acumulada em 96 meses foi menor para os pacientes imunopositivos a proteína p53 e com alto índice de marcação para Ki-67.

A associação entre a expressão das proteínas p53/p21 e as características clínicopatológicas de 150 pacientes com carcinoma espinocelular na mucosa bucal foi verificada por TATEMOTO et al. ${ }^{121}$, em 1998. A positividade das proteínas p53 e p21 não se correlacionaram com a estádio clínico T, porém, a expressão da proteína p53 apresentou associação com a presença de metástase linfonodal e com uma pobre resposta a quimioterapia. Os autores verificaram que pacientes com expressão positiva a p53 apresentaram menor probabilidade de sobrevida acumulada em cinco anos, comparativamente a pacientes negativos a esta imunomarcação. Concluiu-se que embora a expressão da proteína p21 tenha apresentado uma fraca correlação com as características clínico-patológica dos pacientes, a proteína p53 caracterizou-se como um biomarcador de valor prognóstico para pacientes com carcinoma espinocelular de boca. 
O valor da expressão da proteína p53 bem como sua associação com os demais fatores prognósticos foi analisada por ÜNAL; AYHAN; HOSAL ${ }^{128}$, em 1999, em 70 pacientes com carcinoma espinocelular na língua. A imunorreatividade a proteína p53 apresentou associação significativa com a maior extensão anatômica do tumor, presença de metástase linfonodal e com a graduação histológica avançada do tumor primário. A análise multivariada de Cox revelou que a imunopositividade a proteína p53, os estádios clínicos $\mathrm{T}$ e $\mathrm{N}$, a invasão perineural, a graduação histológica do tumor, são variáveis independentes e relacionadas à recorrência tumoral.

A expressão da proteína p53 também evidenciou valor prognóstico no estudo de KANTOLA et al. ${ }^{53}$, em 2000, na análise de 105 pacientes com carcinoma espinocelular na língua. Este estudo evidenciou uma correlação positiva significativa entre a ausência de expressão da proteína p53, o aumento da atividade apoptótica, os altos escores de malignidade e ainda uma associação com parâmetros clínicos como o avançado estadiamento clínico, a idade avançada, o tabagismo e o etilismo. A ausência de expressão da proteína apresentou valor prognóstico para os pacientes com estádios clínicos I e II, com idades acima de 65 anos e altos escores de malignidade sugeridos por BRYNE et al. ${ }^{19}$, apresentando uma menor probabilidade de sobrevida específica.

A alteração progressiva da expressão da proteína p53 mutante em biópsias seqüenciais de displasias epiteliais e de carcinomas espinocelulares bucais desenvolvidos no mesmo sítio anatômico foi analisada por SHAHNAVAZ et al. ${ }^{108}$, em 2000, a partir do estudo longitudinal de 24 espécimes provenientes de dez pacientes. Verificou-se uma associação inconsistente entre a mutação do gene TP53 e o nível de expressão da proteína p53. Conclui-se que durante 
a tumorigênese, a mutação do gene TP53 ocorre nas fases mais tardias, associando-se à progressão e invasão tumoral.

Estes resultados corroboraram com estudo anteriormente realizado por $\mathrm{NG}$ et al. ${ }^{82}$, em 1999, onde a expressão conjunta das proteínas p53, p21, mdm2 e do marcador de proliferação celular MIB-1, foram avaliados em 88 carcinomas espinocelulares de boca. Embora não tenha sido identificada associação entre os marcadores analisados e a classificação clínica TNM ${ }^{122}$, nem entre os próprios marcadores, os autores ressaltaram a alta expressão da proteína p53 nos carcinomas espinocelulares pouco diferenciados.

A importância da alteração da proteína p53 na tumorigênese foi demonstrada por SHIN et al. ${ }^{110}$, em 2001, a partir da expressão de p53 e da polissomia dos cromossomos 9 e 17 em 48 espécimes de carcinoma espinocelular da região de cabeça e pescoço e na mucosa adjacente a neoplasia. Vinte e quatro espécimes apresentaram hiperplasia adjacente à neoplasia e 26 eram lesões displásicas. Verificou-se um aumento gradativo da polissomia cromossômica entre os grupos, durante a tumorigênese, porém as lesões com alteração da expressão de p53 apresentaram aproximadamente duas a quatro vezes mais polissomia. Sugeriu-se que a alteração da expressão de p53 está associada com o aumento das instabilidades genéticas durante as fases mais iniciais da tumorigênese na cabeça e pescoço.

A perda da função supressora do gene TP53 associada à atividade proliferativa das células tumorais pode implicar numa rápida proliferação tumoral. Esta correlação entre a expressão da proteína p53 e a atividade proliferativa celular tem sido demonstrada em alguns trabalhos a partir da avaliação dos anticorpos PCNA ${ }^{83,126}$, Ki-67/MIB-1 $1^{39,82,111}$ e pelo índice mitótico ${ }^{137}$ em carcinomas espinocelulares de boca. 
PCNA corresponde a uma proteína nuclear não histona de $36 \mathrm{kD}$, sintetizada nas fases tardia de G1 e S, que auxilia as DNA polimerases nos mecanismos de duplicação e reparação do DNA durante o ciclo celular. A expressão desta proteína no ciclo celular aumenta gradativamente das fases $\mathrm{G} 1$ e S, decrescendo em G2, não sendo detectada durante a fase M e em células quiescentes, caracterizando-se, portanto, por ser um marcador de células em proliferação ${ }^{39,125}$. Embora alguns autores ${ }^{39,85,86,111,137}$ não tenham demonstrado associação entre a expressão da proteína p53 e o antígeno nuclear de proliferação celular, PCNA, esta proteína caracteriza-se por ser um biomarcador da proliferação celular tumoral durante a carcinogênese, apresentando uma correlação positiva com a progressão tumoral nos carcinomas espinocelulares da cabeça e pescoço ${ }^{109,113}$.

A expressão associada da proteína p53 e do marcador de proliferação celular PCNA foi verficada por NISHIOKA et al. ${ }^{83}$, em 1993, a partir da análise de 20 leucoplasias e 40 carcinomas espinocelulares de boca. As marcações para a proteína p53 e para PCNA tanto nas leucoplasias, como nos carcinomas espinocelulares foram detectadas nas regiões mais invasivas dos espécimes. A imunorreatividade a p53 foi visualizada predominantemente nos carcinomas com um padrão de invasão tumoral difuso, comparativamente aos demais classificados como padrões em cordões e grupo de células. Os autores observaram que os índices de marcação para p53 foram altos em carcinomas espinocelulares com índices de proliferação maiores a 40\%, verificando uma correlação significativa entre a expressão de p53 e as marcações de PCNA, sugerindo assim uma possível relação entre a expressão da proteína p53, a proliferação celular e o grau histológico de malignidade das células tumorais.

STEINBECK et al. ${ }^{115}$, em 1993, analisaram a expressão de PCNA e a ploidia nuclear em 33 lesões displásicas e em 83 carcinomas espinocelulares na mucosa bucal e evidenciaram 
um aumento progressivo da atividade proliferativa nuclear, correlacionado ao aumento do grau de atipia celular. A atividade proliferativa, imunoexpressada pela marcação do PCNA apresentou uma correlação positiva com a classificação morfológica de ANNEROTH; $\mathrm{HANSEN}^{8}$ e com a graduação dos carcinomas espinocelulares, sendo que os carcinomas classificados como grau III (OMS) ${ }^{94}$ apresentaram quase a totalidade das células tumorais PCNA-positivas e aneuplóides. Embora a expressão de PCNA não tenha apresentado valor prognóstico, sua detecção nas camadas mais profundas, refletiram a importância de sua expressão durante a tumorigênese.

A análise da atividade proliferativa tumoral no prognóstico dos pacientes com carcinoma espinocelular foi verificada por STÖRKEL et al. ${ }^{118}$, em 1993. Os autores avaliaram a evolução clínica de cem pacientes com carcinoma espinocelular de boca e verificaram uma associação significativa entre os altos escores de marcação ao PCNA e a menor probabilidade de sobrevida global acumulada em cinco anos, demonstrando uma forte correlação entre os pacientes PCNA-positivos e as pequenas taxas de sobrevida $(p=0,0001)$. STAIBANO et al. ${ }^{113}$, em 1998, encontrou uma correlação inversa significativa entre a positividade ao PCNA e o intervalo livre de doença para pacientes com carcinoma espinocelular de boca.

Além dos marcadores de proliferação celular descritos, alguns biomarcadores relacionados a apoptose como o Bax e Bcl-2 têm sido exaustivamente analisados e correlacionados com a progressão tumoral, com recorrência da doença e com as taxas de sobrevida dos pacientes com carcinomas espinocelulares de cabeça e pescoço.

O gene bcl-2, um dos mais decifrados genes humanos associado aos mecanismos da apoptose e com função repressora deste processo, foi originalmente detectado nos linfomas foliculares de células B onde a translocação cromossômica t(14;18), q(21;32) desregula a 
codificação do mRNA gerando uma super produção da proteína de $26 \mathrm{kD} \mathrm{Bcl-2}{ }^{127}$. A proteína Bcl-2 reside predominantemente na membrana externa da mitocôndria, na membrana do retículo endoplasmático e na membrana nuclear, atuando na inibição dos mecanismos da $\operatorname{apoptose}^{5,63}$. A habilidade da proteína Bcl-2 em inibir a apoptose sem afetar a proliferação celular, definiu o gene bcl-2 como uma nova e importante categoria de

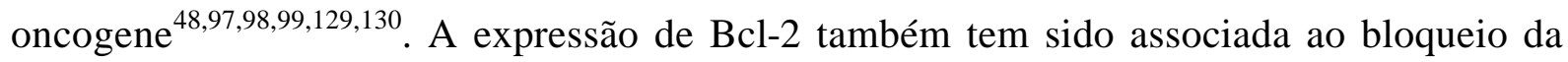
apoptose induzida por agentes terapêuticos quimio e radioterápicos $27,76,96,97,98,99$.

Novas proteínas da família Bcl-2 foram identificadas, esclarecendo a atuação das diversas proteínas participantes na regulação dos mecanismos positivos e negativos da apoptose, como a proteína Bcl-X identificada e caracterizada por BOISE et al. ${ }^{16}$, em 1993. Ressaltou-se neste trabalho que a proteína $\mathrm{Bcl}-\mathrm{X}_{\mathrm{L}}$ apresenta uma alta similaridade estrutural e funcional com $\mathrm{Bcl}-2$, conferindo significativa resistência a apoptose, prevenindo e contribuindo para a inativação deste processo. Inversamente, uma forma curta de mRNA, produzida também por splicing alternativo, codifica uma proteína denominada $\mathrm{Bcl}-\mathrm{X}_{\mathrm{S}}$ que inibe a habilidade supressora da proteína Bcl-2 nos mecanismos da apoptose. A proteína Bcl$\mathrm{X}_{\mathrm{S}}$, embora apresente homologia a Bcl-2, possui, contrariamente a $\mathrm{Bcl}-2$ e a Bcl- $\mathrm{X}_{\mathrm{L}}$, uma atividade inversa nos mecanismos da apoptose.

OLTAVAI et al. ${ }^{88}$, em 1993, identificou uma interação entre a proteína Bcl-2 e uma proteína de $21 \mathrm{kD}$, com uma extensa homologia, denominada Bax, a qual apresenta a função controladora da apoptose. A proporção de Bcl-2/Bax é determinante para a susceptibilidade das células aos estímulos apoptóticos. Quando há o predomínio de Bcl-2, as células apresentam-se protegidas deste processo, porém quando Bax prevalece as células ficam vulneráveis a apoptose, uma vez que sua ação é promotora deste evento. A competição entre 
as proporções via dimerização das proteínas antagonistas $\mathrm{Bcl}-2$ e Bax representa um mecanismo regulador endógeno à morte celular programada.

A habilidade de interação da proteína Bax, via heterodimerização, com outros membros da família Bcl-2, foi demonstrada por SEDLAK et al. ${ }^{104}$, em 1995. Estes autores evidenciaram que a proteína $\mathrm{Bcl}-\mathrm{X}_{\mathrm{L}}$ possui uma forma de interação idêntica a Bcl-2 com a proteína Bax e que esta heterodimerização, via quebra do homodímero Bax/Bax é fundamental para a repressão da apoptose. Os autores ressaltaram ainda que, a perda do efeito letal de Bax ocorre quando aproximadamente metade de sua estrutura apresenta-se heterodimerizada por $\mathrm{Bcl}-2$ ou por $\mathrm{Bcl}-\mathrm{X}_{\mathrm{L}}$, esclarecendo um pouco mais as diferentes vias de controle da apoptose presentes nos diferentes clones tumorais.

O entendimento do maquinário biológico responsável pelo gatilho e manutenção da apoptose contribuiu para a elucidação das alterações morfológicas e bioquímicas que caracterizam este fenômeno. Os mecanismos apoptóticos ocorrem primariamente via mitocôndria e são regidos pelas proteínas pró e antiapoptóticas da família Bcl-2. Estas proteínas co-existem e interagem ligando-se umas às outras formando homo e heterodímeros e a proporção entre estas proteínas norteia a sensibilidade ou a resistência a apoptose ${ }^{44,99}$.

Mesmo sendo expressas e detectadas pela imuno-histoquímica nos carcinomas de cabeça e pescoço, as proteínas Bax, Bcl-2 e Bcl-X parecem não influenciar o prognóstico e/ou a sobrevida dos pacientes. $^{71,113,117}$.

Por outro lado, autores como LORO et al. ${ }^{72}$, SCHOELCH et al. ${ }^{102}$, YAO;IWAI;FURUTA ${ }^{138}$, LOPES et al. ${ }^{71}$ e STOLL et al. ${ }^{117}$ demonstraram uma associação significativa entre estas proteínas e os parâmetros morfológicos tumorais, como grau de 
diferenciação celular e padrão de invasão tumoral, porém sem apresentar valor prognóstico para os pacientes com carcinoma espinocelular de boca.

FRIEDMAN et al. $^{35}$, em 1997, demonstraram o valor prognóstico da expressão da proteína Bcl-2 em 33 pacientes como carcinoma espinocelular da cabeça e pescoço. A positividade a esta proteína conferiu aos pacientes uma probabilidade de sobrevida global acumulada em cinco anos de $64,8 \%$, enquanto os pacientes negativos a esta marcação apresentaram probabilidade de sobrevida igual a 94,4\% $(p=0,0379)$. Os autores verificaram que independentemente do tratamento empregado, os pacientes imunopositivos à proteína Bcl-2 apresentaram um pior prognóstico $(p=0,0047)$.

O valor prognóstico dos marcadores pró-apotótico Bax e de proliferação celular Ki-67 e AgNOR foram avaliados por XIE et al. ${ }^{136}$, em 1999, em 85 carcinomas espinocelulares de língua. Os pacientes com altos escores de marcação a proteína Bax apresentaram maior probabilidade de sobrevida livre de doença, acumulada em 12 anos, comparativamente a pacientes com baixos escores a esta proteína $(p=0,0001)$. Altos valores quantificados de Ki-67 e AgNOR apresentaram uma correlação significativa com um prognóstico desfavorável. Na análise multivariada de Cox, as variáveis, imunoexpressão positiva da proteína Bax, porcentagem de AgNOR, estádio clínico T e N, foram fatores prognósticos independentes. Concluiu-se que os marcadores apoptóticos e de proliferação celular são parâmetros prognósticos para o carcinoma espinocelular de língua.

Em 1999, XIE et al. ${ }^{135}$, também avaliaram a correlação entre os marcadores apoptóticos Bax, Bcl-2, p53 e o prognóstico dos 85 pacientes com carcinoma espinocelular na língua. Os autores verificaram correlação significativa entre os altos escores de expressão da proteína Bax e o alto índice apoptótico, porém, não identificaram correlação entre a expressão 
da proteína p53 e as demais proteínas apoptóticas analisadas. A probabilidade de sobrevida acumulada em 12 anos foi maior para os pacientes com altos escores de positividade a Bax $(p=0,0012)$ e com altos índices apoptóticos $(p=0,0053)$. Correlação inversa foi verificada para os pacientes com altos escores de positividade a Bcl-2, estes apresentaram um pior prognóstico, com menor probabilidade de sobrevida ( $p=0,0262)$, o mesmo sendo detectado para os pacientes com altos valores da proporção $\operatorname{Bcl}-2 / \operatorname{Bax}(p=0,0001)$. O risco relativo de morte para pacientes com altos valores proporcionais de $\mathrm{Bcl}-2 / \mathrm{Bax}$ foi de 4,57. A proteína p53 não foi fator prognóstico neste estudo, porém os pacientes com valores de positividade acima de $30 \%$ a esta proteína apresentaram uma tendência ao um prognóstico desfavorável ( $p=0,0576)$. A análise de regressão de Cox revelou que os estádios $\mathrm{T}$ e $\mathrm{N}$, a expressão da proteína Bax e a proporção Bcl-2/Bax são fatores prognósticos independentes. Sugeriu-se que os índices de apoptose espontânea e a expressão de Bax e Bcl-2 possuem valor prognóstico nos carcinomas espinocelulares de língua, inclusive delineando a resposta a radioterapia e que a expressão da proporção Bcl-2/Bax é uma variável de alto valor prognóstico para a sobrevida específica dos pacientes.

PENA et al. ${ }^{93}$, em 1999, analisaram a expressão das proteínas p53, Bcl-2 e Bcl-X quanto ao prognóstico de pacientes com carcinomas espinocelulares da cabeça e pescoço, com estádios clínicos avançados. As marcações imuno-histoquímicas foram avaliadas semiquantitativamente por meio de escores. Observou-se uma alta expressão de Bcl- $\mathrm{X}_{\mathrm{L}}$ e Bcl2 nos carcinomas espinocelulares com graus histológicos mais avançados $(\mathrm{OMS})^{94}$; sem a ocorrência de positividade concomitante destas duas proteínas em todos espécimes analisados. A expressão da proteína p53 não se correlacionou com a expressão de Bcl-2 e Bcl-X e também, não se caracterizou como fator prognóstico neste estudo. As marcações para Bcl- $\mathrm{X}_{\mathrm{L}}$ 
foram observadas em $52 \%$ dos espécimes e para Bcl-2 em $17 \%$ dos carcinomas espinocelulares. Observou-se que os tumores que não marcaram Bcl-2 apresentaram uma alta expressão de $\mathrm{Bcl}-\mathrm{X}_{\mathrm{L}}$, sugerindo que nestes espécimes a inibição da apoptose provavelmente tenha ocorrido via $\mathrm{Bcl}-\mathrm{X}_{\mathrm{L}}$. A expressão das proteínas $\mathrm{Bcl}-\mathrm{X}_{\mathrm{L}}$ e $\mathrm{Bcl}-2$ não se correlacionou com outros parâmetros como gênero, raça, idade, estádio clínico T, N e grau histológico dos carcinomas espinocelulares. A expressão de $\mathrm{Bcl}-\mathrm{X}_{\mathrm{L}}$ não apresentou correlação com a sobrevida global, com a sobrevida livre de doença e com sobrevida específica, embora os tumores positivos apenas a $\mathrm{Bcl}-\mathrm{X}_{\mathrm{L}}$ tenham apresentado maior resistência às terapias empregadas. A expressão da proteína Bcl-2 inversamente, apresentou correlação com prognóstico favorável. Os pacientes que expressaram positividade a Bcl-2 apresentaram maior probabilidade de sobrevida específica $(\mathrm{p}<0,05)$, com significativo controle locoregional da doença. Os autores concluíram que a alta expressão da proteína Bcl-2, associa-se a um prognóstico favorável, independentemente do estádio clínico $\mathrm{N}$, inclusive em pacientes com carcinomas espinocelulares localmente invasivos.

A inibição da apoptose parece ter valor crítico no desenvolvimento do câncer bem como na determinação de sua resposta terapêutica, tendo como membros principais deste processo, as proteínas da família Bcl-2. A detecção das respectivas proteínas, bem como das proteínas reguladoras da proliferação celular, não apenas delineiam o comportamento biológico do tumor, mas também, podem caracterizar e predizer a resposta tumoral ao tratamento dos pacientes com carcinoma espinocelular da cabeça e pescoço, como demonstrado por COSTA et. al. ${ }^{27}$, GALLO et al. ${ }^{36,37}$, HOMMA et al. ${ }^{47}$, PENA et al. ${ }^{93}$, RAVI et al. ${ }^{96}$ e NOUTOMI et al. ${ }^{84}$. 
3 PROPOSIÇÃO 


\section{PROPOSIÇÃO}

O presente estudo tem por objetivo:

analisar o carcinoma escamoso basalóide na mucosa bucal, localizados na língua, soalho bucal, gengiva inferior e área retromolar, quanto às características demográficas, clínicas, tratamento e evolução destes tumores, bem como aos aspectos microscópicos da morfologia e da invasão tumoral;

caracterizar o perfil imuno-histoquímico, da proliferação celular e apoptose nos carcinomas escamosos basalóides, determinado a partir da análise do anticorpo PCNA, da expressão das proteínas pró-apoptóticas p53 e Bax e da proteína antiapoptótica Bcl-X;

comparar as características demográficas, clínicas, morfológicas e imuno-histoquímicas do carcinoma escamoso basalóide e do carcinoma espinocelular pouco diferenciado com estadiamento e localização equivalentes;

avaliar o valor prognóstico das características clínicas, morfológicas e imunohistoquímicas dos pacientes com carcinoma escamoso basalóide e com carcinoma espinocelular pouco diferenciado na mucosa bucal. 
4 MATERIAL E MÉTODOS 


\section{MATERIAL E MÉTODOS}

\subsection{População de estudo e seleção da amostra}

Este estudo consistiu de uma análise retrospectiva de pacientes portadores de carcinoma espinocelular primários de boca, com estádios clínicos I, II, III e IV, submetidos a tratamento no Departamento de Cirurgia de Cabeça e Pescoço e Otorrinolaringologia do Centro de Tratamento e Pesquisa do Hospital do Câncer A.C. Camargo (São Paulo - S.P.).

Para a composição da amostra foram adaptados os critérios de inclusão e exclusão, utilizados por KOWALSKI et al. ${ }^{62}$, listados abaixo.

\section{Critérios de inclusão:}

1. pacientes com tumor primário diagnosticado como carcinoma espinocelular, confirmado por biópsia e exame anatomopatológico prévios, localizados em língua, soalho bucal, gengiva inferior e área retromolar;

2. pacientes não submetidos a tratamento prévio;

3. pacientes submetidos à cirurgia como tratamento inicial com ou sem radioterapia pós-operatória;

4. seguimento clínico completo;

5. disponibilidade dos blocos de parafina dos referidos tumores, bem como a adequada conservação dos espécimes;

6. disponibilidade de fragmentos representativos das neoplasias. 
Para a análise microscópica dos espécimes, além dos critérios citados acima, selecionaram-se fragmentos neoplásicos satisfatórios para avaliação de infiltração óssea e margens cirúrgicas.

\section{Critérios de exclusão:}

1. contra-indicação cirúrgica, pacientes considerados inoperáveis;

2. presença de metástase a distância no momento de admissão no hospital;

3. presença de tumores primários simultâneos;

4. pacientes submetidos àquimioterapia como tratamento inicial;

5. pacientes que recusaram o tratamento.

Os carcinomas selecionados foram divididos em dois grupos segundo as características microscópicas.

GRUPO CEB - Carcinoma Escamoso Basalóide- tumores apresentando mais de 80\% de componente basalóide

GRUPO CEC - Carcinoma Espinocelular Pouco Diferenciado

Os critérios morfológicos utilizados para a seleção dos casos de Carcinoma Escamoso Basalóide foram baseados na descrição inicial de WAIN et al. ${ }^{131}$ caracterizados por:

1. proliferação sólida de células basalóides, em uma configuração lobular, justapostas ao epitélio de revestimento;

2. pequenas ilhotas de células com citoplasma escasso; 
3. células com núcleo hipercromático, sem nucléolo evidente;

4. pequenos espaços císticos contendo material similar a mucina e positivos ao PAS e/ou Alcian Blue;

5. focos de necrose por coagulação nas áreas centrais dos lóbulos tumorais;

6. associação dos componentes basalóide e escamoso, este último caracterizado por focos de células com diferenciação escamosa, focos de displasia epitelial e/ou carcinoma espinocelular

7. hialinização do estroma.

Os critérios morfológicos para a identificação do componente escamoso nos cortes microscópicos de carcinoma escamoso basalóide foram constituídos pela presença da queratinização individual de células, presença de pontes intercelulares, de pérolas córneas e do arranjo pavimentoso ou em mosaico do epitélio estratificado.

A seleção dos espécimes de Carcinoma Espinocelular Pouco Diferenciado (GRAU 3) foi efetuada a partir dos critérios morfológicos estabelecidos pela OMS (1997) ${ }^{94}$, baseado na descrição original de BRODERS, caracterizado por:

1. discreta semelhança do componente tumoral ao epitélio estratificado pavimentoso da mucosa bucal;

2. queratinização discreta ou ausente;

3. pontes intercelulares escassas;

4. alta atividade mitótica e presença de figuras de mitoses atípicas; 
5. pleomorfismo celular e nuclear acentuados;

6. presença de células multinucleadas.

\subsection{Registro dos dados clínicos e microscópicos}

As informações clínicas referentes aos pacientes, obtidas a partir do banco de dados pertencente ao Hospital do Câncer A.C. Camargo e os dados microscópicos relativos à peça cirúrgica foram registradas em ficha própria (Anexo 1). Estes registros incluíram a identificação e os dados demográficos dos pacientes, informações relativas à história clínica, ao exame locorregional, cirurgia, radioterapia pós-operatória, quimioterapia pós-operatória, microscopia da peça cirúrgica inicial e evolução do paciente. No caso dos pacientes vivos, a evolução clínica foi atualizada até o ano de 2002 por meio de consulta aos respectivos prontuários arquivados no SAME (Serviço de Arquivo Médico) do referido hospital.

\subsection{Análise microscópica}

Para a análise morfológica qualitativa dos espécimes selecionados, a partir das peças cirúrgicas incluídas em parafina, obteveram-se dois cortes com $3 \mu \mathrm{m}$ de espessura, os quais foram corados pela Hematoxilina e Eosina (HE) e pelo Ácido Periódico de Schiff (PAS), seguindo os procedimentos histotécnicos de rotina do Laboratório de Histologia do Instituto Ludwig de Pesquisa Sobre o Câncer.

A análise morfológica dos tumores primários foi realizada individualmente por três examinadores (F.C.G.S.G., G.L., D.T.O.) utilizando-se de um microscópio óptico binocular da marca ZEISS, modelo Axioskop2 plus, sendo os pontos de discordância entre estes reavaliados e estabelecidos por um consenso. Utilizou-se um corte representativo do tumor primário de cada caso, analisando-se todo o fragmento neoplásico presente na lâmina, com 
aumentos de 5X, 10X e 40X, para a determinação das características microscópicas relativas ao padrão de configuração e morfologia tumoral.

\subsection{Variáveis de estudo}

As variáveis analisadas neste estudo referem-se aos dados demográficos relativos aos pacientes como o gênero (masculino ou feminino), a idade e a raça (branca, ou não branca).

Quanto à história clínica dos pacientes, pesquisou-se o tempo de história (meses), tabagismo e etilismo. Analisaram-se também as queixas dos pacientes, se referentes ao tumor primário, às metástases regionais ou a ambos. No exame locorregional, a localização do tumor primário foi registrada como: 1 língua; 2-soalho bucal; 3-gengiva inferior; 4-área retromolar.

As lesões foram descritas quanto às características clínicas em ulcerovegetante ou ulceroinfiltrativa.

Registraram-se as classificações clínicas TNM/UICC ${ }^{122}$, T (T1, T2, T3 e T4) e N (N0, N1, N2a, N2b, N2c e N3), agrupando-as para análise em T1-2 e T3-4, N0 e N+.

Quanto ao tratamento, registrou-se a data da cirurgia, a realização ou não de esvaziamento cervical, o tipo de esvaziamento cervical (ipsilateral ou ipsilateral e contralateral simultâneos), a data da alta hospitalar e a realização ou não de radioterapia e quimioterapia pós-operatórias.

A análise microscópica inicial da peça cirúrgica baseou-se primeiramente no diagnóstico do tumor primário referente ao laudo anatomopatológico (CECI, CECII, CECIII, CEB, Ca indiferenciado). 
Classificou-se o componente basalóide quantificando a porcentagem observada no espécime $(80-90 \%,>90 \%)$ e o padrão de invasão (sólido ou lobular, trabecular, tubular, cribiforme). Verificou-se a continuidade da neoplasia com a mucosa bucal (presente, ausente / mucosa não observada).

Analisou-se a presença ou ausência de características morfológicas e histoquímicas como: disposição em paliçada das células periféricas das ilhotas tumorais, pontes intercelulares, figuras de mitoses, espaços císticos e estruturas ductiformes e sua positividade ao PAS, disjunção epitélio tumoral-conjuntivo. Avaliou-se a necrose central por coagulação (ausente, presente) e a porcentagem observada no espécime $(<10 \%, 10-40 \%,>40 \%)$ bem como a hialinização (ausente, intratumoral, peritumoral ou ambas).

O componente escamoso associado foi avaliado quanto a sua distribuição (intercalado às células basalóides ou adjacente ao componente basalóide). Verificou-se a presença ou a ausência de pontes intercelulares, disqueratoses e pérolas córneas.

No carcinoma espinocelular pouco diferenciado, avaliou-se a ausência ou a presença de pontes intercelulares, disqueratoses e perolas córneas. Características como hipercromatismo nuclear e pleomorfismo celular, foram classificadas em categorias (discreto, moderado ou intenso), utilizando-se parâmetros comparativos entre os diferentes espécimes neoplásicos analisados. Avaliou-se a ausência ou presença da necrose por coagulação e a porcentagem observada no espécime $(<10 \%, 10-40 \%,>40 \%)$.

A presença ou ausência de disjunção epitélio tumoral/tecido conjuntivo, bem como o padrão de invasão no "front" tumoral (compressivo, cordões grossos, cordões finos e células isoladas) foram avaliados nos dois grupos. Analisou-se também, quando presente, a 
intensidade do infiltrado inflamatório (discreto, moderado ou intenso), utilizando-se parâmetros comparativos entre os diferentes espécimes neoplásicos. Verificou-se ainda, a presença ou ausência de embolização angiolinfática, infiltração perineural, muscular e óssea. As margens cirúrgicas dos tumores foram classificadas em livres ou comprometidas.

Foram avaliados e registrados em categorias os índices de marcação dos anticorpos PCNA, p53, Bax e Bcl-X de ambos grupos tumorais. Esta análise está descrita juntamente com a metodologia imuno-histoquímica.

Quanto à evolução dos pacientes, registrou-se a ocorrência ou não de recidiva local, cervical, de metástase a distância e de segundo tumor primário.

Com o objetivo de caracterização da amostra, registraram-se também a data da primeira recidiva, os locais da recidiva (0-não teve; 1-local; 2-pescoço ipsilateral; 3-pescoço contralateral; 4-pulmão; 5-osso; 6-fígado; 7-outra a distância e 8-recidiva em local ignorado), a data do diagnóstico do segundo tumor primário e o local do segundo tumor primário.

Registraram-se a data da última informação de seguimento e a situação do paciente, 1vivo sem evidência da doença (000); 2-vivo com câncer; 3- morte por intercorrência cirúrgica (Moci); 4-morte decorrente do câncer (Moca) e 5-morte por outras causas não relacionadas ao câncer (Moass); 6-perdido de vista. Definiu-se como pacientes perdidos de vista, aqueles com menos de cinco anos de seguimento que deixaram de retornar por um período igual ao dobro estipulado. Pacientes assintomáticos perdidos de vista após cinco anos foram classificados como vivos livres da doença. Os prontuários dos pacientes perdidos de vista foram encaminhados aos responsáveis pela convocação destes pacientes e as respostas obtidas foram posteriormente conferidas. 


\subsection{Método imuno-histoquímico}

As marcações imuno-histoquímicas dos espécimes tumorais nos dois grupos estudados seguiram os protocolos de reações utilizados no Setor de Imuno-histoquímica do Centro de Pesquisas da Fundação Antônio Prudente, utilizando-se da técnica estreptavidina-biotinaperoxidase, previamente padronizada no plano piloto, para os seguintes anticorpos:

1. Bax, clone B-9, Santa Cruz, código sc-7480, título pré-estabelecido: 1:100

2. Bcl-X, policlonal, Santa Cruz, código sc-634, título pré-estabelecido: 1:400

3. p53, clone DO7, Dako, código M7001, título pré-estabelecido: 1:100

4. PCNA, clone PC10, Dako, código M0879, título pré-estabelecido: 1:9000

A recuperação antigênica para a marcação imuno-histoquímica dos anticorpos Bcl-X e Bax foi realizada por meio da incubação dos espécimes em solução tampão citrato $10 \mathrm{mM}$ pH 6,0, usando a panela de pressão como fonte geradora de calor úmido. A recuperação antigênica para a marcação imuno-histoquímica dos anticorpos p53 e PCNA foi realizada por meio da incubação dos espécimes em solução tampão citrato $10 \mathrm{mM}$ pH 6,0, com o emprego do calor irradiado do aparelho de microondas.

Os espécimes foram incubados com os anticorpos primários diluídos em tampão PBS contendo albumina bovina, BSA $1 \%$ (Sigma A9647 USA) e azida sódica, $\mathrm{NaN}_{3}$ 0,1\%, por 16 a 18 horas a $4^{\circ} \mathrm{C}$ em câmara úmida.

Os espécimes foram novamente incubados com o anticorpo secundário biotiniladoreagente C (Biotinylated affinity-isolated goat anti mouse/rabbit Ig) do kit de detecção 
StreptABComplex/HRP Duet (mouse/rabbit), Dako A/S K0492 Denmark, com diluição de 1/200 em PBS, por um período de 30 minutos a $37^{\circ} \mathrm{C}$.

O produto final da reação antígeno-anticorpo foi visualizado por meio da incubação dos espécimes em solução substrato cromógeno 3,3' Diaminobezidine Tetrahydrochloride, DAB 60mg\% (Sigma D-5637 USA); Dimetilsulfóxido, DMSO 1ml; $\mathrm{H}_{2} \mathrm{O}_{2} 6 \%$ (20 volumes) $1 \mathrm{ml}$, PBS $100 \mathrm{ml}$, por cinco minutos a $37^{\circ} \mathrm{C}$, ao abrigo da luz.

Os espécimes foram contracorados com solução de Hematoxilina de Harris por um minuto e em seguida montados com a utilização de resina adesiva Entellan Neu (Merck 1,07961 Germany) e lamínulas.

Controles positivo e negativo foram utilizados para cada anticorpo. Para os anticorpos Bcl-X e PCNA utilizou-se como controles positivos, fragmento de tecido normal de tonsila humana e como controle negativo, um corte representativo deste tecido com omissão dos anticorpos primários específicos nos procedimentos imuno-histoquímicos.

Para os anticorpos Bax e p53 utilizou-se como controle positivo um espécime de carcinoma ductal invasivo, de mama humana, sendo a positividade confirmada a partir da marcação das células neoplásicas. Como controle negativo utilizou-se um corte representativo deste tumor com omissão do anticorpo primário específico nos procedimentos imunohistoquímicos.

\subsection{Avaliação imuno-histoquímica}


A avaliação da expressão imuno-histoquímica dos anticorpos PCNA, p53, Bax e Bcl$\mathrm{X}$ nos espécimes de CEB e CEC foi realizada individualmente por meio de um sistema computadorizado de captura de imagens da região do "front" de invasão tumoral. Um total de 30 campos microscópicos de cada espécime tumoral (17 CEB e 27 CEC) para cada anticorpo analisado foi capturado a partir de uma câmera (marca SAMSUNG, modelo SCC-131) acoplada ao microscópio (Axioskop2 plus, marca ZEISS) com objetiva de 40X. Esta câmera encontrava-se conectada a um microcomputador (INTEL-Pentium IV) contendo um sistema de processamento e análise de imagens (Image Lab - Softium Informática Ltda - ME). Cada imagem microscópica capturada pelo programa correspondia a uma área de $10.704,0116 \mu \mathrm{m}^{2}$. O valor total da área dos 30 campos analisados, na região do "front" de invasão tumoral de cada espécime correspondia a $321.120,348 \mu \mathrm{m}^{2}$.

A avaliação da expressão dos anticorpos nucleares PCNA e p53 foi realizada a partir da quantificação da porcentagem de células tumorais positivas, determinadas pela coloração acastanhada dos núcleos, contadas num total de 1000 células tumorais no "front" de invasão em cada espécime, utilizando-se de uma objetiva de 40X, nos 17 espécimes do grupo CEB e nos 27 espécimes do grupo CEC. A partir do valor mediano de marcação obtido para cada anticorpo nos dois grupos de carcinomas (CEB e CEC), codificaram-se as variáveis continuas em variáveis categóricas. Para a avaliação da expressão do anticorpo PCNA utilizaram-se a as categorias $60 \%$ e $>60 \%$ de marcações positivas; para o anticorpo p53 as categorias adotadas foram $23 \%$ e $>23 \%$.

Os anticorpos citoplasmáticos Bax e Bcl-X foram avaliados por método semiquantitativo de escores, baseado na soma da proporção e da intensidade das células tumorais imunopositivas aos anticorpos, como descrito por Soini et al. ${ }^{112}$ : 
A proporção de células tumorais com positividade citoplasmática foi dividida em quatro grupos:

$$
\begin{aligned}
& 0=\text { ausência de células tumorais imunopositivas } \\
& 1=<25 \% \text { de células tumorais imunopositivas } \\
& 2=25 \%-50 \% \text { de células tumorais imunopositivas } \\
& 3=51 \%-75 \% \text { de células tumorais imunopositivas } \\
& 4=>75 \% \text { de células tumorais imunopositivas }
\end{aligned}
$$

A intensidade da imunomarcação citoplasmática foi avaliada:

$$
\begin{aligned}
& 0=\text { ausência de imunomarcação } \\
& 1=\text { imunomarcação fraca } \\
& 2=\text { imunomarcação moderada } \\
& 3=\text { imunomarcação forte } \\
& 4=\text { imunomarcação intensa }
\end{aligned}
$$

A soma dos escores, baseada na proporção e intensidade foi dividida em três grupos:

0: Escore 0 = ausência de imunomarcação

1: Escores 1-4 = imunomarcação fraca

2: Escores 5-8 = imunomarcação forte 


\subsection{Análise estatística}

Os registros das informações clínicas e microscópicas dos pacientes com carcinoma escamoso basalóide e com carcinoma espinocelular pouco diferenciado foram armazenados em um banco de dados, elaborado em planilha do Microsoft Excel (Anexos 1-9). As análises estatísticas foram realizadas utilizando-se o programa para microcomputador STATA versão 7.0 (StataCorp. 2001) $)^{114}$.

Primeiramente, para a verificação das diferenças entre as médias das idades foi utilizado o teste $t$ Student, e posteriormente a variável idade foi categorizada. Para avaliar a associação entre as variáveis demográficas, clínicas e microscópicas realizou-se o teste exato de Fisher ou o teste qui-quadrado, com o nível de significância igual a 5\%.

A análise de sobrevida foi feita pelo estimador produto-limite de Kaplan-Meier ${ }^{54}$ A comparação entre as curvas de sobrevida foi realizada pelo teste log-rank, com o nível de significância igual a 5\%.

O tempo de seguimento para a obtenção da sobrevida global foi calculado em meses entre a data da cirurgia do tumor primário e o óbito ou até a data da última informação objetiva do paciente.

Para a análise da sobrevida específica considerou-se o tempo em meses decorrido entre a cirurgia do tumor primário e o óbito por este tumor específico ou até a última informação objetiva do seguimento dos casos censurados. Consideraram-se para a análise da sobrevida livre de doença, o tempo em meses decorrido entre a cirurgia do tumor primário e o aparecimento da recorrência tumoral ou até a última informação objetiva do seguimento no caso da não ocorrência do evento em foco. 
Foram considerados "não censurados" para os cálculos das sobrevidas global, específica e livre de doença todos os casos em que ocorreu um evento de interesse (óbito para a sobrevida global, óbito pelo tumor primário para a sobrevida específica e recorrência tumoral para a sobrevida livre de doença). Os casos em que os eventos não ocorreram até a data da última informação objetiva do seguimento foram classificados como "censurados".

Utilizou-se o modelo de regressão de $\operatorname{Cox}^{29}$ para avaliar a independência da variante histológica (CEB ou CEC) em relação às demais variáveis estudadas, na determinação do prognóstico. O método "stepwise backward procedure” foi utilizado para seleção das variáveis independentes do modelo de regressão de Cox, considerando-se o nível de significância de $10 \%$ para a inclusão das variáveis. Para a realização das análises de regressão de Cox utilizou-se o programa estatístico STATA (StataCorp. 2001) ${ }^{114}$.

\subsection{Registro fotográfico}

Os campos microscópicos tumorais mais representativos dos grupos CEB e CEC corados pelo HE, PAS e imunomarcados pelo PCNA, p53, Bax e Bcl-X foram registrados a partir de um fotomicroscópio (Axioskop2 plus, marca ZEISS).

\subsection{Questões éticas}

Este estudo foi aprovado pela Comissão de Ética em Pesquisa (CEP) do Hospital do Câncer A.C. Camargo, em reunião de 29 de agosto de 2000, Projeto de Pesquisa n ${ }^{\circ}$ 273/00. 
5 RESULTADOS 


\section{RESULTADOS}

\subsection{Casuística}

Realizou-se inicialmente um levantamento dos carcinomas espinocelulares de boca no banco de dados do Departamento de Cirurgia de Cabeça e Pescoço e Otorrinolaringologia e no Departamento de Anatomia Patológica do Hospital do Câncer, no período de 1970 a 2000. Um total de 776 espécimes, corados pela Hematoxilina e Eosina, diagnosticados como carcinomas espinocelulares primários e localizados na língua, soalho bucal, gengiva inferior e área retromolar foram analisados, revelando uma frequiência de 17 carcinomas escamosos basalóides e 27 carcinomas espinocelulares pouco diferenciados, constituindo, respectivamente os grupos CEB e CEC (Tabela 2).

TABELA 2 - Distribuição dos carcinomas escamosos basalóides e carcinomas espinocelulares pouco diferenciados de boca, quanto aos critérios de inclusão estabelecidos. Hospital do Câncer, São Paulo, 1970 a 2000

\begin{tabular}{lcc}
\hline \hline \multicolumn{1}{c}{ Grupo } & $\mathbf{N}^{\mathbf{0}}$ & $\mathbf{\%}$ \\
\hline Carcinoma Escamoso Basalóide & $\mathbf{1 7}$ & $\mathbf{2 , 2}$ \\
Carcinoma Espinocelular Pouco Diferenciado & $\mathbf{2 7}$ & $\mathbf{3 , 5}$ \\
Carcinoma Espinocelular Bem/Moderadamente Diferenciado & 732 & 94,3 \\
\hline TOTAL & 776 & 100,0 \\
\hline \hline
\end{tabular}

\subsection{Caracterização demográfica e clínica da população de estudo segundo grupo}

A análise dos 17 pacientes com carcinoma escamoso basalóide e dos 27 pacientes com carcinoma espinocelular pouco diferenciado, revelou um predomínio de pacientes do gênero masculino e da raça branca, para ambos grupos. A idade mínima observada dos pacientes do 
grupo CEB foi de 43 anos e a máxima 77 anos (idade média 59,5 e desvio padrão 9,3). No grupo CEC, a idade mínima observada dos pacientes foi de 33 anos e a máxima 78 anos (idade média 58,3 e desvio padrão 11,8). Observou-se uma alta porcentagem de pacientes tabagistas e etilistas nos dois grupos analisados (Tabela 3).

TABELA 3 - Distribuição das características demográficas e da história clínica dos pacientes com carcinoma escamoso basalóide e com carcinoma espinocelular pouco diferenciado de boca. Hospital do Câncer, São Paulo, 1970 a 2000

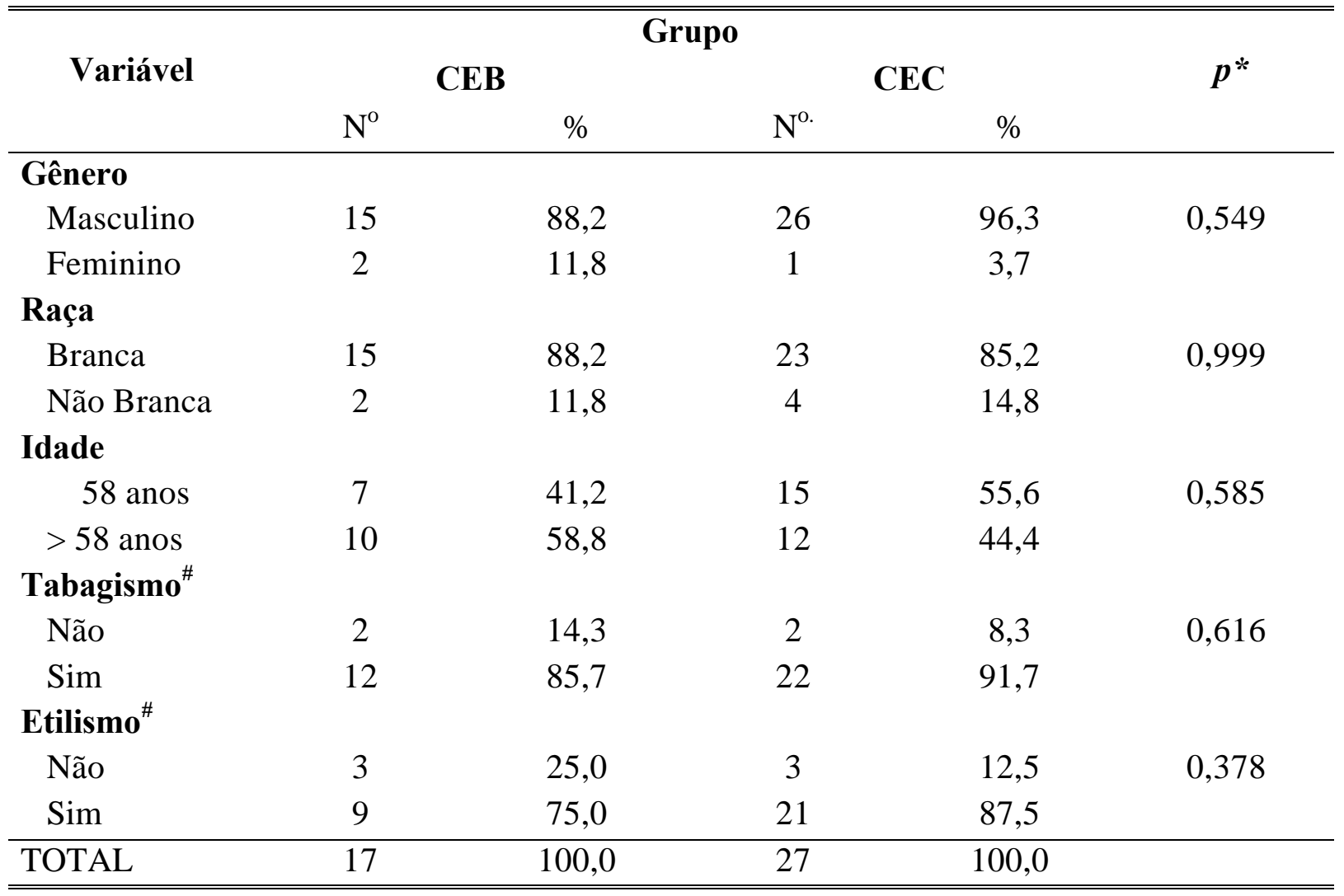

CEB: Carcinoma Escamoso Basalóide, CEC: Carcinoma Espinocelular Pouco Diferenciado $p^{*}$ : nível descritivo do teste exato de Fisher

\#: excluídos os pacientes com informações ignoradas

A análise clínica dos pacientes dos grupos CEB e CEC revelou que no momento diagnóstico os pacientes de ambos grupos apresentaram estádios clínicos avançados. Quanto à extensão anatômica do tumor, no grupo CEB 70,6\% dos pacientes apresentaram tumores 
classificados como T3-4, no grupo CEC, 77,8\% dos tumores eram também T3-4. Verificou-se que $70,6 \%$ dos pacientes do grupo CEB e 70,4\% do grupo CEC apresentaram linfonodos regionais palpáveis no momento do diagnóstico (Tabela 4).

A localização mais freqüente do CEB foi no soalho bucal e do CEC na área retromolar/gengiva inferior. Clinicamente, 41,2\% dos CEBs apresentaram aspecto ulcerovegetante e $58,8 \%$ aspecto ulceroinfiltrativo. No grupo CEC, $29,6 \%$ dos tumores apresentaram aspecto clínico ulcerovegetante e 70,4\% ulceroinfiltrativo (Tabela 4).

TABELA 4 - Distribuição das características clínicas dos pacientes com carcinoma escamoso basalóide e com carcinoma espinocelular pouco diferenciado de boca. Hospital do Câncer, São Paulo, 1970 a 2000

\begin{tabular}{|c|c|c|c|c|c|}
\hline \multirow{3}{*}{ Variável } & \multicolumn{4}{|c|}{ Grupo } & \multirow{3}{*}{$p$} \\
\hline & \multicolumn{2}{|c|}{ CEB } & \multicolumn{2}{|c|}{ CEC } & \\
\hline & $\mathrm{N}^{\mathrm{o}}$ & $\%$ & $\mathrm{~N}^{\mathrm{o}}$ & $\%$ & \\
\hline \multicolumn{6}{|l|}{$\mathbf{T}$} \\
\hline $\mathrm{T} 1-2$ & 5 & 29,4 & 6 & 22,2 & $0,724^{*}$ \\
\hline $\mathrm{T} 3-4$ & 12 & 70,6 & 21 & 77,8 & \\
\hline \multicolumn{6}{|l|}{$\mathbf{N}$} \\
\hline No & 5 & 29,4 & 8 & 29,6 & $0,999 *$ \\
\hline $\mathrm{N}+$ & 12 & 70,6 & 19 & 70,4 & \\
\hline \multicolumn{6}{|l|}{ Estádio clínico } \\
\hline I-II & 3 & 17,6 & 5 & 18,5 & $0,999 *$ \\
\hline III-IV & 14 & 82,4 & 22 & 81,5 & \\
\hline \multicolumn{6}{|l|}{ Localização } \\
\hline Língua & 4 & 23,5 & 7 & 25,9 & \\
\hline Soalho & 9 & 52,9 & 7 & 25,9 & $0,153 * *$ \\
\hline Retromolar/gengiva & 4 & 23,5 & 13 & 48,1 & \\
\hline \multicolumn{6}{|l|}{ Tipo de lesão } \\
\hline Ulcerovegetante & 7 & 41,2 & 8 & 29,6 & $0,521 *$ \\
\hline Ulceroinfiltrativa & 10 & 58,8 & 19 & 70,4 & \\
\hline TOTAL & 17 & 100,0 & 27 & 100,0 & \\
\hline
\end{tabular}

CEB: Carcinoma Escamoso Basalóide, CEC: Carcinoma Espinocelular Pouco Diferenciado $p^{*}$ : nível descritivo do teste exato de Fisher $-p^{* *}$ : nível descritivo do teste qui-quadrado 
Todos os pacientes incluídos neste estudo foram submetidos à cirurgia como tratamento inicial, de acordo com os critérios de inclusão. O esvaziamento cervical foi realizado em todos os pacientes dos grupos CEB e CEC. O esvaziamento cervical ipsilateral foi realizado em 52,9\% dos pacientes do grupo CEB e em 74,1\% dos pacientes do grupo CEC (Tabela 5).

A radioterapia pós-operatória adjuvante foi realizada em $88,2 \%$ dos pacientes com CEB e 85,2\% dos pacientes com CEC. A utilização da quimioterapia pós-operatória adjuvante foi verificada em 17,6\% dos pacientes com CEB e em 29,6\% dos pacientes com CEC (Tabela $5)$.

Quanto à evolução dos pacientes, a recidiva local foi detectada com maior frequiência no grupo CEC, em 40,7\% dos pacientes quando comparado ao grupo CEB $(17,6 \%)$, respectivamente em um período de seguimento variável entre 3-168 meses (mediana 26 meses) e entre 3,6-95 meses (mediana 25 meses) (Tabela 5).

A recidiva regional e o desenvolvimento de metástases a distância foram mais freqüentes no grupo CEB. A recidiva regional foi observada em $29,4 \%$ dos pacientes com CEB e em 18,5\% dos pacientes com CEC. As metástases a distância foram detectadas em 23,5\% dos pacientes do grupo CEB e em 14,8\% do grupo CEC. O pulmão foi o sítio mais acometido pelas metástases do carcinoma escamoso basalóide e do carcinoma espinocelular pouco diferenciado. Constatou-se o desenvolvimento de um segundo tumor primário em $17,6 \%$ dos pacientes do grupo CEB e em 14,8\% do grupo CEC (Tabela 5). 
TABELA 5 - Distribuição do tratamento e da evolução dos pacientes com carcinoma escamoso basalóide e com carcinoma espinocelular pouco diferenciado de boca. Hospital do Câncer, São Paulo, 1970 a 2000

\begin{tabular}{|c|c|c|c|c|c|}
\hline \multirow{3}{*}{ Variável } & \multicolumn{4}{|c|}{ Grupo } & \multirow{3}{*}{$p^{*}$} \\
\hline & \multicolumn{2}{|c|}{ CEB } & \multicolumn{2}{|c|}{ CEC } & \\
\hline & $\mathrm{N}^{\mathrm{o}}$ & $\%$ & $\mathrm{~N}^{\mathrm{o}}$ & $\%$ & \\
\hline \multicolumn{6}{|c|}{ Cirurgia/esvaziamento } \\
\hline Ipsilateral & 9 & 52,9 & 20 & 74,1 & 0,198 \\
\hline Bilateral & 8 & 47,1 & 7 & 25,9 & \\
\hline \multicolumn{6}{|l|}{ Radioterapia } \\
\hline Não & 2 & 11,8 & 4 & 14,8 & 0,999 \\
\hline Sim & 15 & 88,2 & 23 & 85,2 & \\
\hline \multicolumn{6}{|l|}{ Quimioterapia } \\
\hline Não & 14 & 82,4 & 19 & 70,4 & 0,486 \\
\hline Sim & 3 & 17,6 & 8 & 29,6 & \\
\hline \multicolumn{6}{|l|}{ Recidiva local } \\
\hline Não & 14 & 82,4 & 16 & 59,3 & 0,184 \\
\hline Sim & 3 & 17,6 & 11 & 40,7 & \\
\hline \multicolumn{6}{|l|}{ Recidiva regional } \\
\hline Não & 12 & 70,6 & 22 & 81,5 & 0,473 \\
\hline Sim & 5 & 29,4 & 5 & 18,5 & \\
\hline \multicolumn{6}{|l|}{ Metástase distância } \\
\hline Não & 13 & 76,5 & 23 & 85,2 & 0,690 \\
\hline Sim & 4 & 23,5 & 4 & 14,8 & \\
\hline \multicolumn{6}{|l|}{ Segundo tumor } \\
\hline Não & 14 & 82,4 & 23 & 85,2 & 0,999 \\
\hline Sim & 3 & 17,6 & 4 & 14,8 & \\
\hline TOTAL & 17 & 100,0 & 27 & 100,0 & \\
\hline
\end{tabular}

CEB: Carcinoma Escamoso Basalóide, CEC: Carcinoma Espinocelular Pouco Diferenciado $p^{*}$ : nível descritivo do teste exato de Fisher 


\subsection{Análise morfológica dos carcinomas}

\subsubsection{Carcinoma escamoso basalóide}

O carcinoma escamoso basalóide apresentou em 52,9\% dos espécimes continuidade com a mucosa bucal (Figura 4A). Verificou-se que 52,9\% dos tumores constituíram-se por $90 \%$ de células basalóides e $23,6 \%$ apresentaram uma proporção de $80 \%$ a $90 \%$ do componente basalóide.

Morfologicamente, o padrão sólido ou também denominado lobular foi observado em 47,1\% dos espécimes e o padrão trabecular em 29,4\% (Figuras 1A, 1B e 4A). Em quatro espécimes, $23,5 \%$, os padrões sólido e trabecular estavam presentes simultaneamente (Tabela 6). Os padrões morfológicos tubular e cribiforme não foram encontrados em nossa amostra.

As principais características do carcinoma escamoso basalóide como a disposição em paliçada das células periféricas das ilhotas tumorais, ausência de pontes intercelulares e a presença de necrose por coagulação central (comedonecrose) estavam presentes em 73,5\%, $94,1 \%$ e $94,1 \%$ respectivamente (Figuras 1A, 1B e 2A, 2B). A necrose por coagulação em 47,1\% dos carcinomas escamosos basalóides correspondeu aproximadamente a $10 \%$ do total do fragmento microscópico analisado, em 41,2\% dos espécimes correspondeu a uma extensão aproximadamente de $10 \%$ a $40 \%$ e em um espécime esta necrose atingiu mais de $40 \%$ das ilhotas tumorais. Em 88,2\% dos espécimes foram observados espaços císticos entretanto em apenas 20,0\% seu conteúdo foi PAS positivo. Estruturas ductiformes estavam presentes em 23,5\% dos carcinomas escamosos basalóides (Tabela 6 e Figura 4B). 
A presença de material hialino, PAS positivo no interior das ilhotas tumorais, principalmente cincundando as células basalóides foi observada em alguns espécimes (Figuras 5A, 5B, 6A, 6B e 7A, 7B).

A disjunção entre o epitélio tumoral e o tecido conjuntivo adjacente foi observada em 76,5\% dos carcinomas escamosos basalóides (Figuras 1A, e 5A e 5B). Em 29,4\% dos espécimes notou-se a hialinização do tecido conjuntivo peritumoral (Tabela 6 e Figura 5A, $5 B)$.

O componente escamoso associado ao basalóide esteve presente de forma intercalada em $76,5 \%$ dos espécimes caracterizando-se principalmente pela presença de pontes intercelulares, pérolas córneas e disqueratoses (Tabela 6 e Figura 3A, 3B). Em três espécimes $(17,3 \%)$ não se detectou a presença do componente escamoso associado. 
TABELA 6 - Distribuição das características morfológicas do carcinoma escamoso basalóide. Hospital do Câncer, São Paulo, 1970 a 2000

\begin{tabular}{|c|c|c|}
\hline \multirow[t]{2}{*}{ Variável } & \multicolumn{2}{|c|}{ Carcinoma Escamoso Basalóide } \\
\hline & $\mathrm{N}^{\mathrm{O}}$ & $\%$ \\
\hline \multicolumn{3}{|l|}{ Continuidade mucosa } \\
\hline Ausente & 6 & 35,3 \\
\hline Presente & 9 & 52,9 \\
\hline Não observada & 2 & 11,8 \\
\hline \multicolumn{3}{|l|}{ Morfologia tumoral } \\
\hline Sólido / lobular & 8 & 47,1 \\
\hline Trabecular & 5 & 29,4 \\
\hline Ambos & 4 & 23,5 \\
\hline \multicolumn{3}{|l|}{ Disposição em paliçada } \\
\hline Ausente & 4 & 23,5 \\
\hline Presente & 13 & 73,5 \\
\hline \multicolumn{3}{|c|}{ Pontes intercelulares células basalóides } \\
\hline Ausente & 16 & 94,1 \\
\hline Presente & 1 & 5,9 \\
\hline \multicolumn{3}{|l|}{ Espaços Císticos } \\
\hline Ausente & 2 & 11,8 \\
\hline Presente & 15 & 88,2 \\
\hline $\operatorname{PAS}(+)$ & 3 & 20,0 \\
\hline \multicolumn{3}{|l|}{ Estruturas ductiformes } \\
\hline Ausente & 13 & 76,5 \\
\hline Presente & 4 & 23,5 \\
\hline $\operatorname{PAS}(+)$ & - & - \\
\hline \multicolumn{3}{|l|}{ Disjunção tumor/conjuntivo } \\
\hline Ausente & 4 & 23,5 \\
\hline Presente & 13 & 76,5 \\
\hline \multicolumn{3}{|l|}{ Hialinização peritumoral } \\
\hline Ausente & 12 & 70,6 \\
\hline Presente & 5 & 29,4 \\
\hline \multicolumn{3}{|c|}{ Necrose central - comedonecrose } \\
\hline Ausente & 1 & 5,9 \\
\hline Presente & 16 & 94,1 \\
\hline \multicolumn{3}{|c|}{ Componente escamoso associado } \\
\hline Ausente & 3 & 17,3 \\
\hline Intercalado & 13 & 76,5 \\
\hline Adjacente & 1 & 5,9 \\
\hline TOTAL & 17 & 100,0 \\
\hline
\end{tabular}



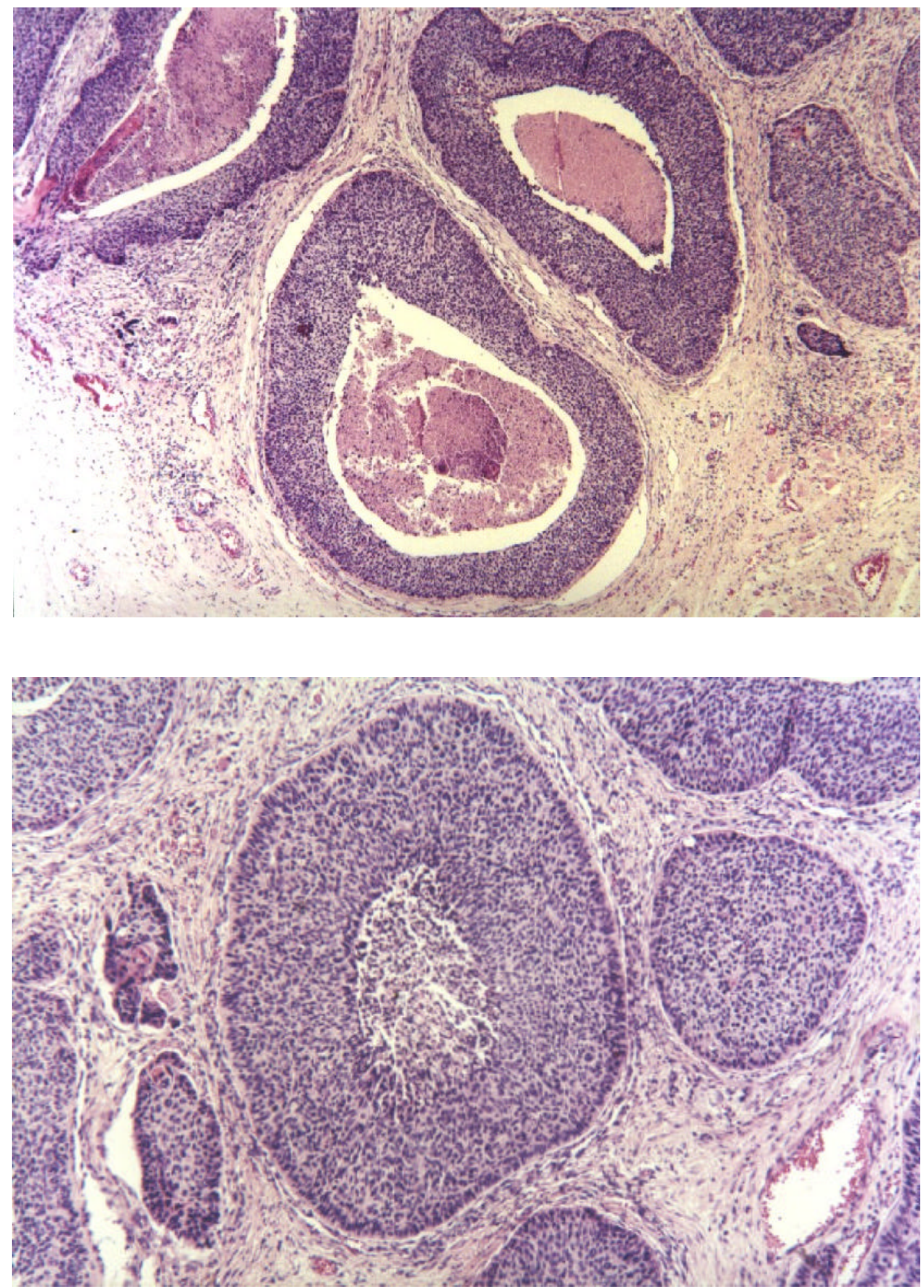

FIGURA 1 - A e B - Padrão de invasão compressivo do CEB, configuração tumoral em lóbulos/ilhotas, com comedonecrose central e disjunção epitélio tumoral/conjuntivo. (HE, aumento original $\mathrm{A}=50 \mathrm{x}$ e $\mathrm{B}=100 \mathrm{x}$ ) 

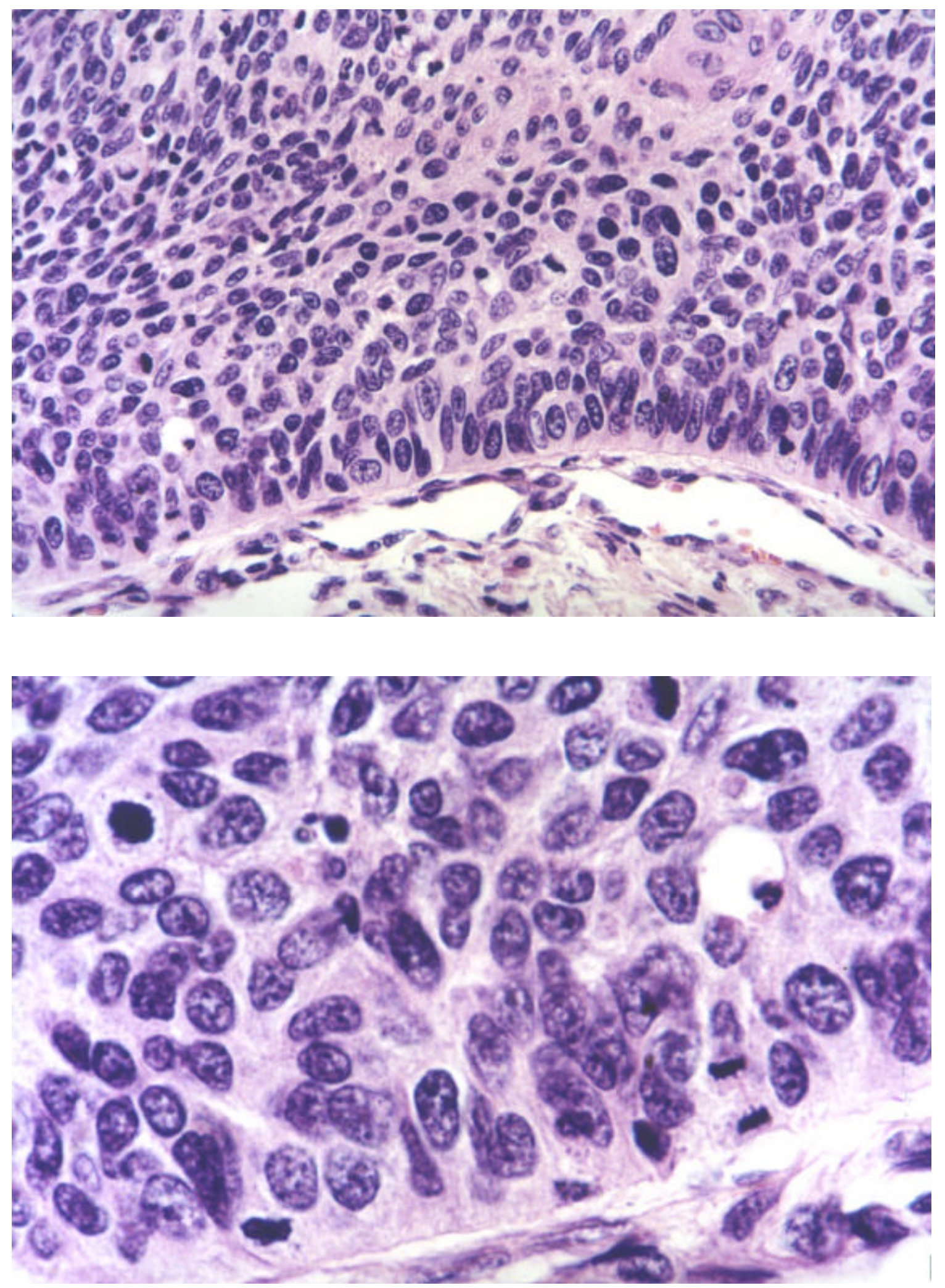

FIGURA 2 - CEB com células basalóides periféricas dispostas em paliçada, caracterizadas por escasso citoplasma e ausência da visualização das pontes intercelulares (A). Em B destacam-se numerosas figuras de mitoses. ( $\mathrm{HE}$, aumento original $\mathrm{A}=400 \mathrm{x}$ e $\mathrm{B}=1000 \mathrm{x}$ ) 

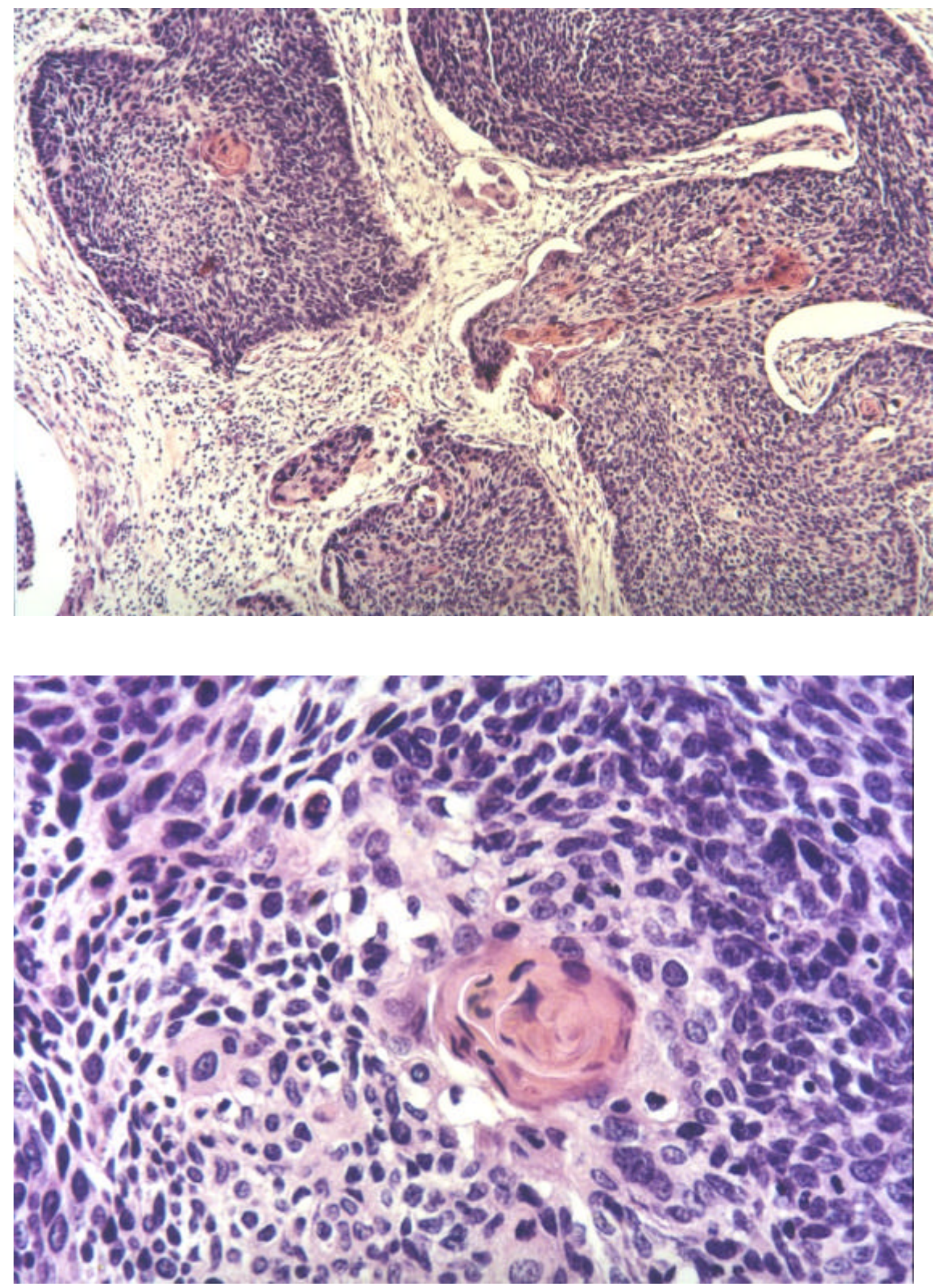

FIGURA 3 - Componente escamoso associado ao CEB. Observar a presença de células escamosas e de pérola córnea em continuidade com as células basalóides. (HE, aumento original $\mathrm{A}=100$ e $\mathrm{B}=400 \mathrm{x}$ ) 

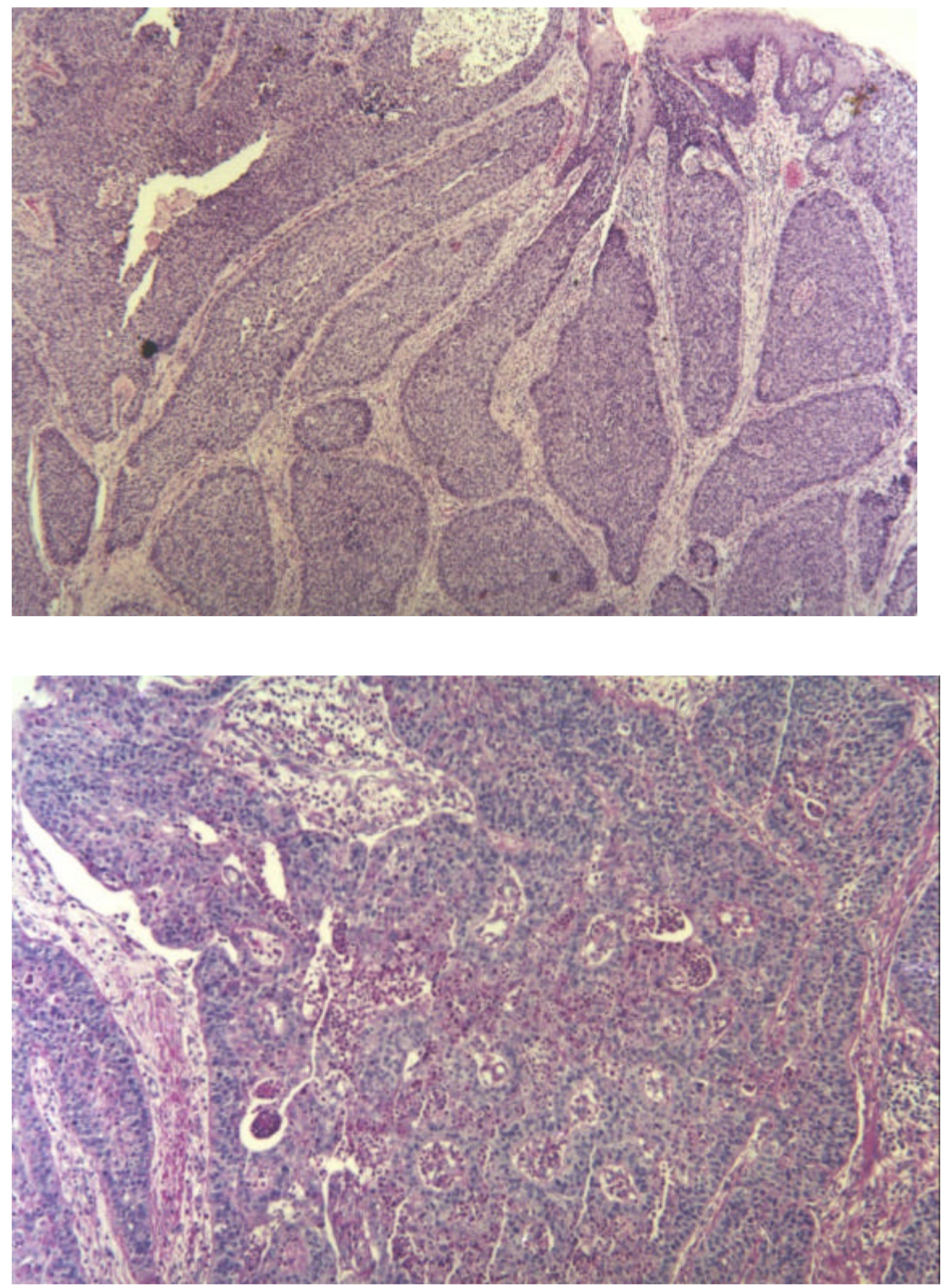

FIGURA 4 - CEB em continuidade com a mucosa bucal (A). Em B, as células basalóides encontram-se organizadas em estruturas ductiformes. (HE, aumento original $\mathrm{A}=50 \mathrm{x}$ e PAS, aumento original $\mathrm{B}=100 \mathrm{x}$ ) 

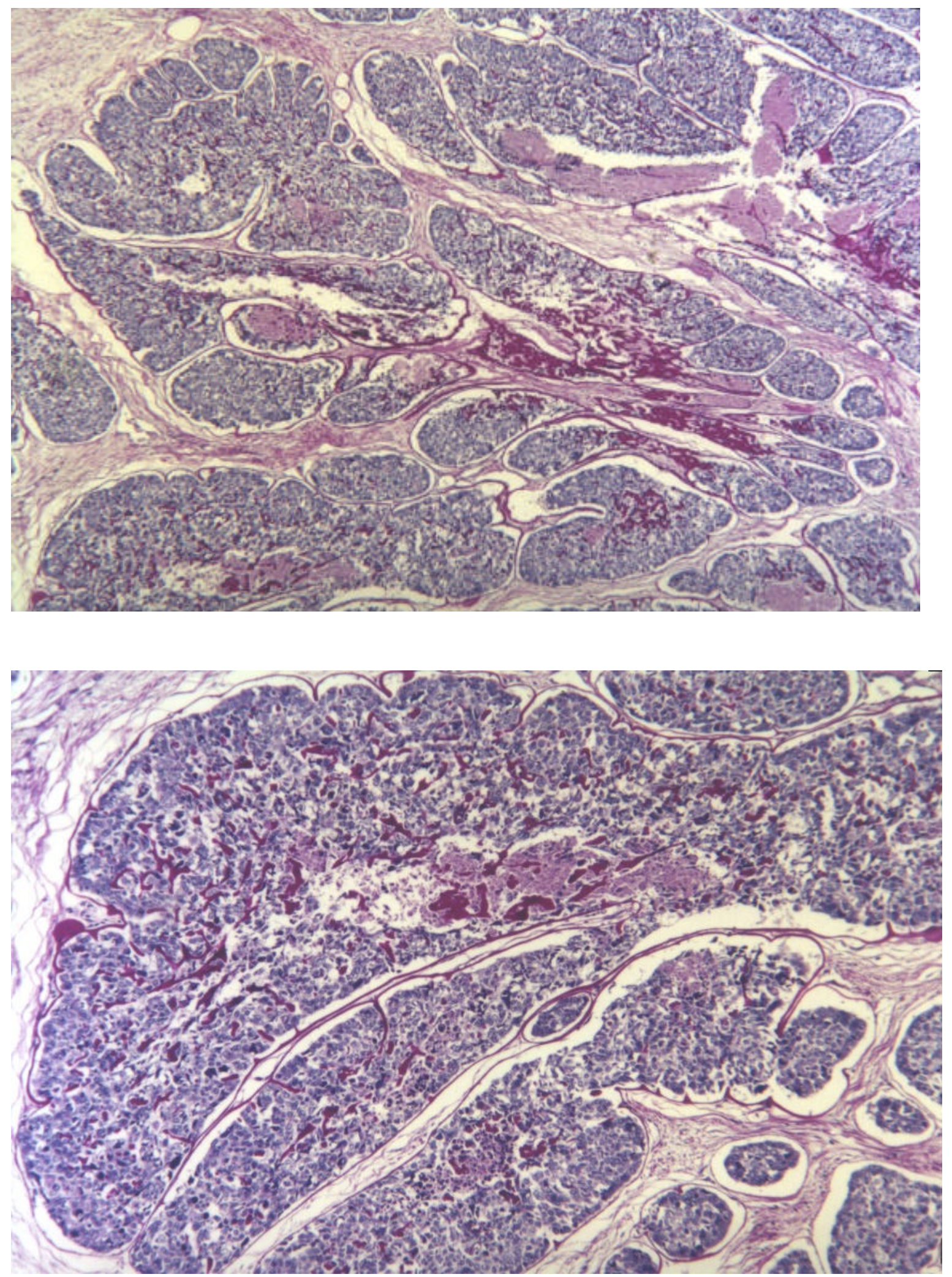

FIGURA 5 - CEB apresentando extensas áreas de disjunção epitélio tumoral/tecido conjuntivo e hialinização intra e peritumoral (A e B). (PAS, aumento original A=50x e $\mathrm{B}=100 \mathrm{x}$ ) 

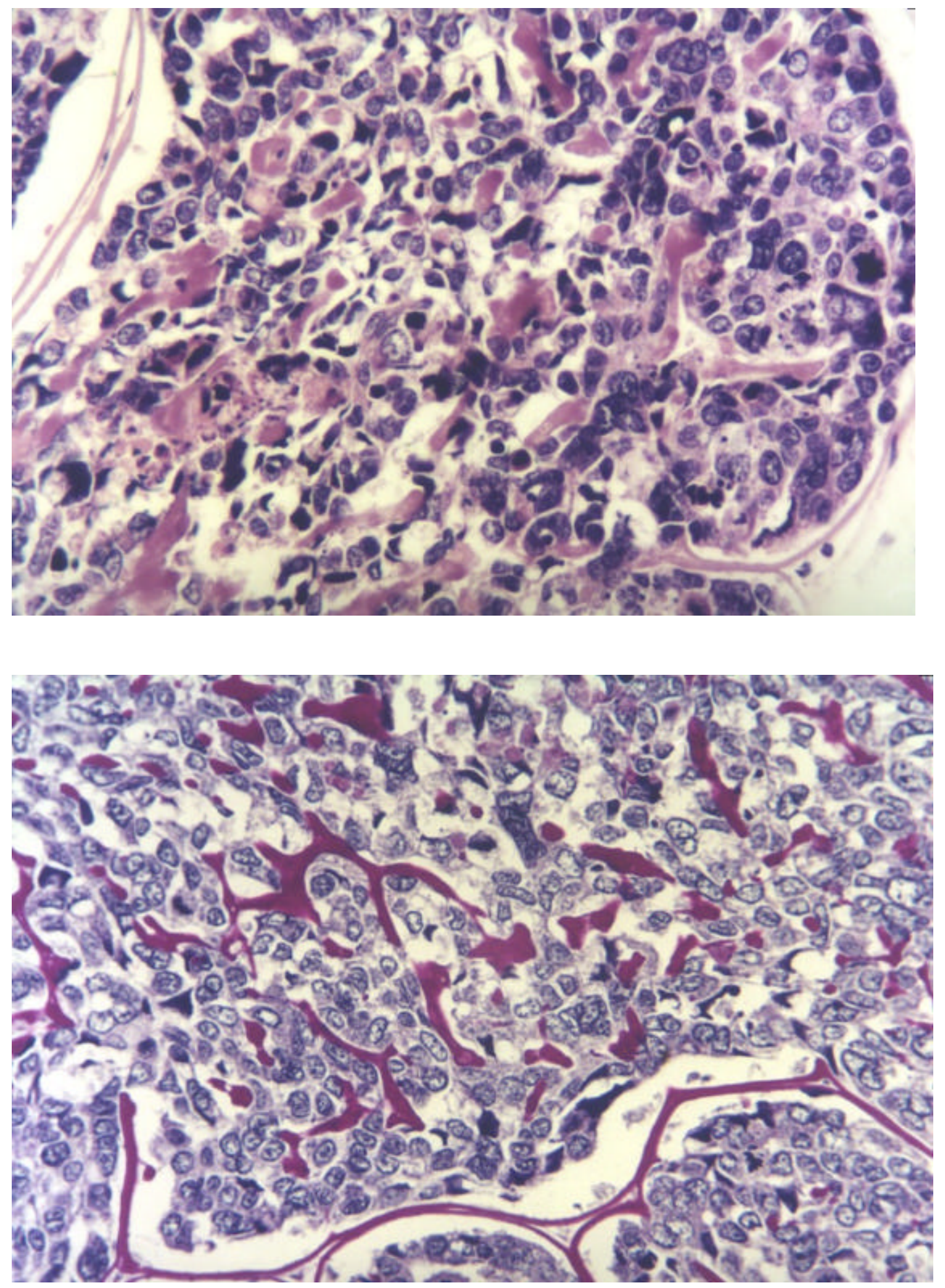

FIGURA 6 - Presença de material hialino (A), PAS positivo (B) entre as células basalóides do CEB. (HE, aumento original $A=400 x$ e PAS, aumento original 400x) 

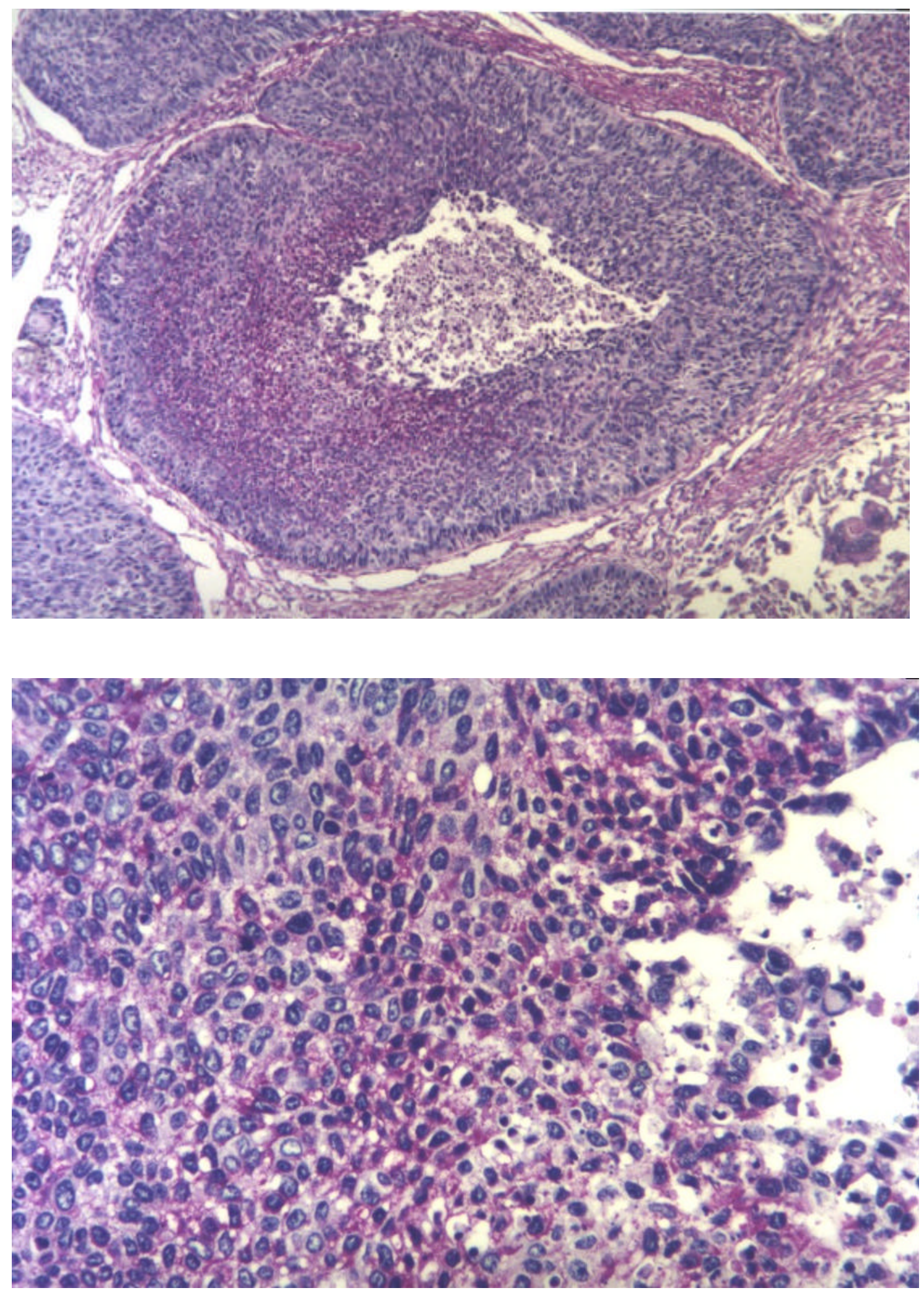

FIGURA 7 - Ilhota tumoral exibindo material hialino PAS positivo (A), circundando as células basalóides do CEB. (PAS, aumento original $A=100 x$ e $B=400 x$ ) 


\subsubsection{Carcinoma espinocelular pouco diferenciado}

A avaliação microscópica dos carcinomas espinocelulares pouco diferenciados revelou a presença de pontes intercelulares em 40,4\% dos espécimes, de disqueratoses em 77,8\%, entretanto, apenas 33,3\% dos espécimes apresentaram pérolas córneas. A necrose por coagulação foi visualizada em $77,8 \%$ dos carcinomas espinocelulares pouco diferenciados, em $51,9 \%$ a necrose por coagulação correspondeu aproximadamente a $10 \%$ do total do fragmento microscópico analisado e em um espécime, a necrose atingiu mais de $40 \%$ das ilhotas tumorais. O hipercromatismo e o pleomorfismo intensos foram observados em 59,3\% e 77,8\% dos espécimes respectivamente (Tabela 7 e Figuras 8A, e 9A, 9B).

TABELA 7 - Distribuição das características morfológicas do carcinoma espinocelular pouco diferenciado. Hospital do Câncer, São Paulo, 1970 a 2000.

\begin{tabular}{lcc}
\hline \multicolumn{1}{c}{ Variável } & \multicolumn{2}{c}{ Carcinoma Espinocelular Pouco Diferenciado } \\
\cline { 2 - 3 } & $\mathrm{N}^{\mathbf{0}}$ & $\%$ \\
\hline $\begin{array}{l}\text { Pontes intercelulares } \\
\text { Ausente }\end{array}$ & 16 & 59,3 \\
Presente & 11 & 40,4 \\
Disqueratose & & \\
$\quad$ Ausente & 6 & 22,2 \\
Presente & 21 & 77,8 \\
Pérolas córne as & & \\
$\quad$ Ausente & 18 & 66,7 \\
Presente & 9 & 33,3 \\
Hipercromatismo & & \\
$\quad$ Discreto & 2 & 7,4 \\
Moderado & 9 & 33,3 \\
Intenso & 16 & 59,3 \\
Pleomorfismo & & 22,2 \\
Moderado & 6 & 77,8 \\
Intenso & 21 & 22,2 \\
Necrose por coagulação & & 77,8 \\
$\quad$ Ausente & 6 & 100,0 \\
Presente & 21 & \\
\hline TOTAL & 27 & \\
\hline \hline
\end{tabular}


O padrão de invasão tumoral observado microscopicamente para os dois grupos tumorais analisados (CEB e CEC) será descrito conjuntamente a seguir.

O "front" de invasão tumoral em $58,8 \%$ dos espécimes de carcinoma escamoso basalóide apresentou o padrão morfológico compressivo (Figura 1A) e este mesmo padrão foi observado em $25,9 \%$ dos carcinomas espinocelulares pouco diferenciados. O padrão infiltrativo foi detectado predominantemente no grupo CEC, 74,1\% (Figura 8A, 8B), sendo observado em 41,2\% dos espécimes de carcinoma escamoso basalóide (Tabela 8).

A invasão tumoral infiltrativa foi caracterizada microscopicamente por células epiteliais neoplásicas dispostas em cordões grossos 33,3\%, cordões finos $18,5 \%$, e células isoladas, 3,7\%. Em cinco espécimes mais de um tipo de invasão tumoral foi detectada, sendo a presença de células tumorais isoladas associadas aos cordões tumorais finos ou grossos (Figuras 8A, 8B, 9A, 9B, 10A, 10B e 11A, 11B). Nos carcinomas escamosos basalóides, com invasão tumoral infiltrativa, verificou-se mais comumente a disposição das células neoplásicas em cordões grossos; a associação de dois padrões de invasão foi observado em três espécimes, sendo caracterizado pela presença de cordões tumorais finos e grossos.

O infiltrado inflamatório moderado foi observado em 41,2\% do grupo CEB e 37,0\% dos espécimes do grupo CEC (Tabela 8).

A embolização angiolinfática esteve presente em $29,4 \%$ dos tumores do grupo CEB e em 3,7\% do grupo CEC. A infiltração perineural foi detectada em 17,6\% do grupo CEB e em 59,3\% do grupo CEC (Figura 11A, 11B). Em 70,6\% dos espécimes do grupo CEB e em 85,2\% do grupo CEC notou-se infiltração tumoral muscular (Figura 10A, 10B). A infiltração óssea foi identificada, respectivamente, em $36,4 \%$ e $55,6 \%$ dos tumores dos grupos CEB e 
CEC. As margens cirúrgicas apresentaram-se livres em 93,8\% dos carcinomas escamosos basalóides e em 81,8\% dos carcinomas espinocelulares pouco diferenciados (Tabela 8).

O esvaziamento cervical ipsilateral foi realizado nos 17 pacientes com CEB. Destes, a análise microscópica revelou ausência de metástase regional em oito pacientes (47,0\%). Dos nove pacientes com CEB e com comprometimento linfonodal (53,0\%), cinco pacientes $(55,6 \%)$ apresentavam de 1 a 4 linfonodos positivos e quatro pacientes (44,5\%) apresentavam mais de quatro linfonodos positivos. O esvaziamento cervical contralateral foi realizado em oito pacientes $(47,0 \%)$ com CEB, sendo que destes, em cinco pacientes $(62,5 \%)$ a ausência de metástaste regional foi confirmada microscopicamente. Dos três pacientes com CEB e com comprometimento linfonodal contralateral $(37,5 \%)$, dois pacientes $(66,7 \%)$ apresentavam de 1 a 4 linfonodos positivos e um paciente com mais de quatro linfonodos positivos $(33,4 \%)$.

No grupo CEC o esvaziamento cervical ipsilateral foi realizado nos 27 pacientes analisados. A ausência e a presença de comprometimento linfonodal ipsilateral foi confirmada pela análise microscópica, respectivamente em nove pacientes $(33,4 \%)$ e em 18 pacientes (66,7\%). Dos 18 pacientes com CEC e com comprometimento linfonodal ipsilateral, confirmados microscopicamente, dez $(55,6 \%)$ apresentavam de 1 a 4 linfonodos positivos e oito $(44,5 \%)$ mais de quatro linfonodos positivos. Dos sete pacientes com CEC que realizaram esvaziamento cervical contralateral (26,0\%), a ausência de comprometimento linfonodal foi, microscopicamente confirmada em quatro pacientes $(57,1 \%)$. Dos três pacientes com CEC e com comprometimento linfonodal contralateral $(42,8 \%)$, dois pacientes $(66,7 \%)$ apresentavam de 1 a 4 linfonodos positivos e um paciente com mais de quatro linfonodos positivos $(33,4 \%)$. 
TABELA 8 - Distribuição das características morfológicas do carcinoma escamoso basalóide e do carcinoma espinocelular pouco diferenciado de boca. Hospital do Câncer, São Paulo, 1970 a 2000.

\begin{tabular}{|c|c|c|c|c|c|}
\hline \multirow{3}{*}{ Variável } & \multicolumn{4}{|c|}{ Grupo } & \multirow{3}{*}{$p$} \\
\hline & \multicolumn{2}{|c|}{ CEB } & \multicolumn{2}{|c|}{ CEC } & \\
\hline & $\mathrm{N}^{\mathrm{o}}$ & $\%$ & $\mathrm{~N}^{\mathrm{o}}$ & $\%$ & \\
\hline \multicolumn{6}{|l|}{ Padrão de invasão } \\
\hline Compressivo & 10 & 58,8 & 7 & 25,9 & $0,055^{*}$ \\
\hline Infiltrativo & 7 & 41,2 & 20 & 74,1 & \\
\hline \multicolumn{6}{|c|}{ Infiltrado Inflamatório } \\
\hline Ausente & 1 & 5,9 & 3 & 11,1 & \\
\hline Discreto & 6 & 35,3 & 9 & 33,3 & $0,945 * *$ \\
\hline Moderado & 7 & 41,2 & 10 & 37,0 & \\
\hline Intenso & 3 & 17,6 & 5 & 18,5 & \\
\hline \multicolumn{6}{|l|}{ Embolização } \\
\hline Ausente & 12 & 70,6 & 26 & 96,3 & $0,025^{*}$ \\
\hline Angiolinfática & 5 & 29,4 & 1 & 3,7 & \\
\hline \multicolumn{6}{|c|}{ Infiltração perineural } \\
\hline Ausente & 14 & 82,4 & 11 & 40,7 & $0,012^{*}$ \\
\hline Presente & 3 & 17,6 & 16 & 59,3 & \\
\hline \multicolumn{6}{|c|}{ Infiltração muscular } \\
\hline Ausente & 5 & 29,4 & 4 & 14,8 & $0,275^{*}$ \\
\hline Presente & 12 & 70,6 & 23 & 85,2 & \\
\hline \multicolumn{6}{|l|}{ Infiltração óssea ${ }^{\#}$} \\
\hline Ausente & 7 & 63,6 & 8 & 44,4 & $0,450^{*}$ \\
\hline Presente & 4 & 36,4 & 10 & 55,6 & \\
\hline \multicolumn{6}{|c|}{ Margens cirúrgicas $^{\#}$} \\
\hline Livres & 15 & 93,8 & 18 & 81,8 & $0,374^{*}$ \\
\hline Comprometidas & 1 & 6,3 & 4 & 18,2 & \\
\hline TOTAL & 17 & 100,0 & 27 & 100,0 & \\
\hline
\end{tabular}

CEB: Carcinoma Escamoso Basalóide, CEC: Carcinoma Espinocelular Pouco Diferenciado $p^{*}$ : nível descritivo do teste exato de Fisher $-p^{* *}$ : nível descritivo do teste qui-quadrado \#: excluídos os pacientes com informações ignoradas 

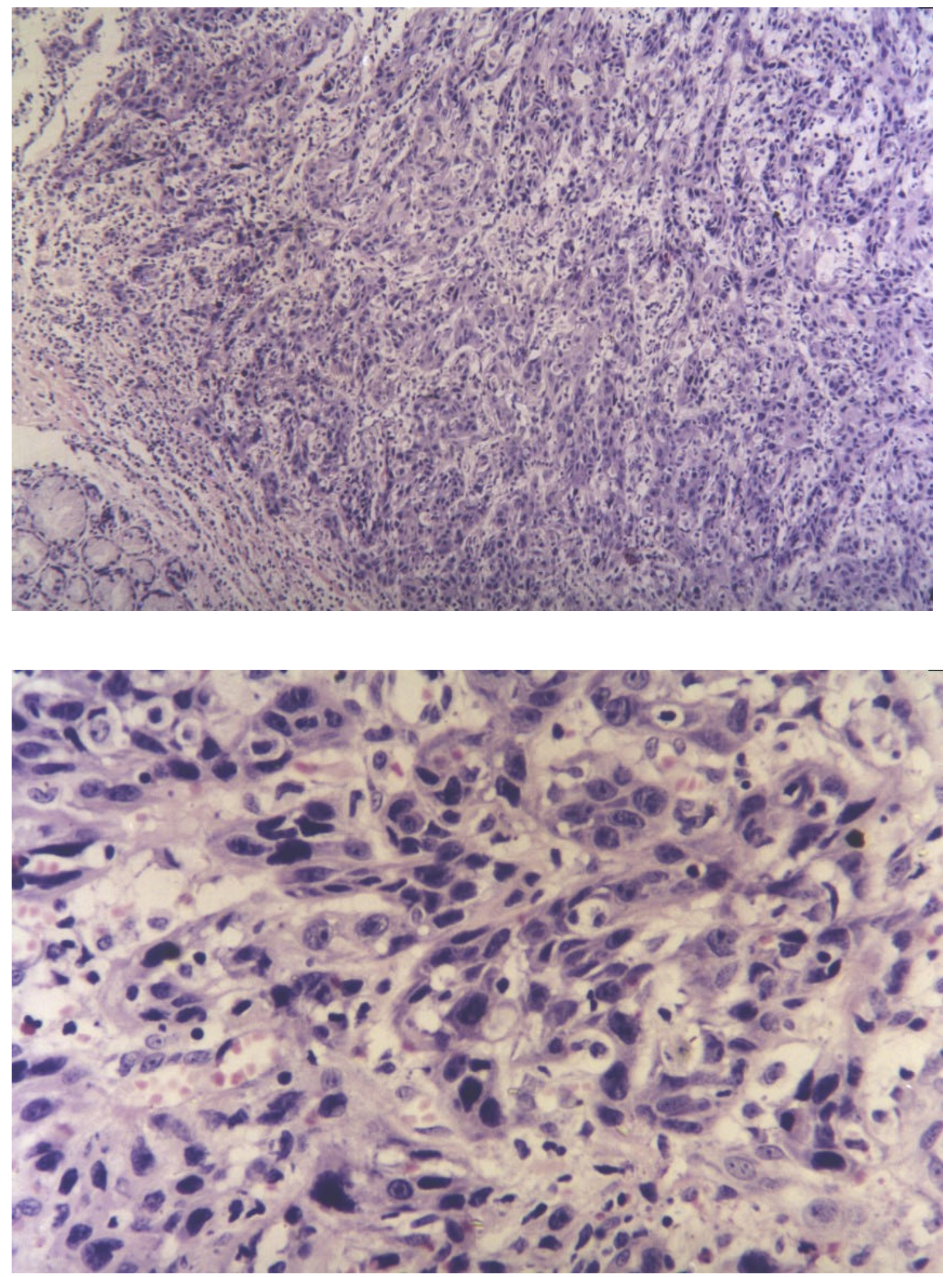

FIGURA 8 - CEC com padrão de invasão tumoral infiltrativo em cordões finos (A). Observar o pleomorfismo celular e as numerosas figuras de mitoses (B). (HE, aumento original $A=100 x$ e $B=400 x$ ) 

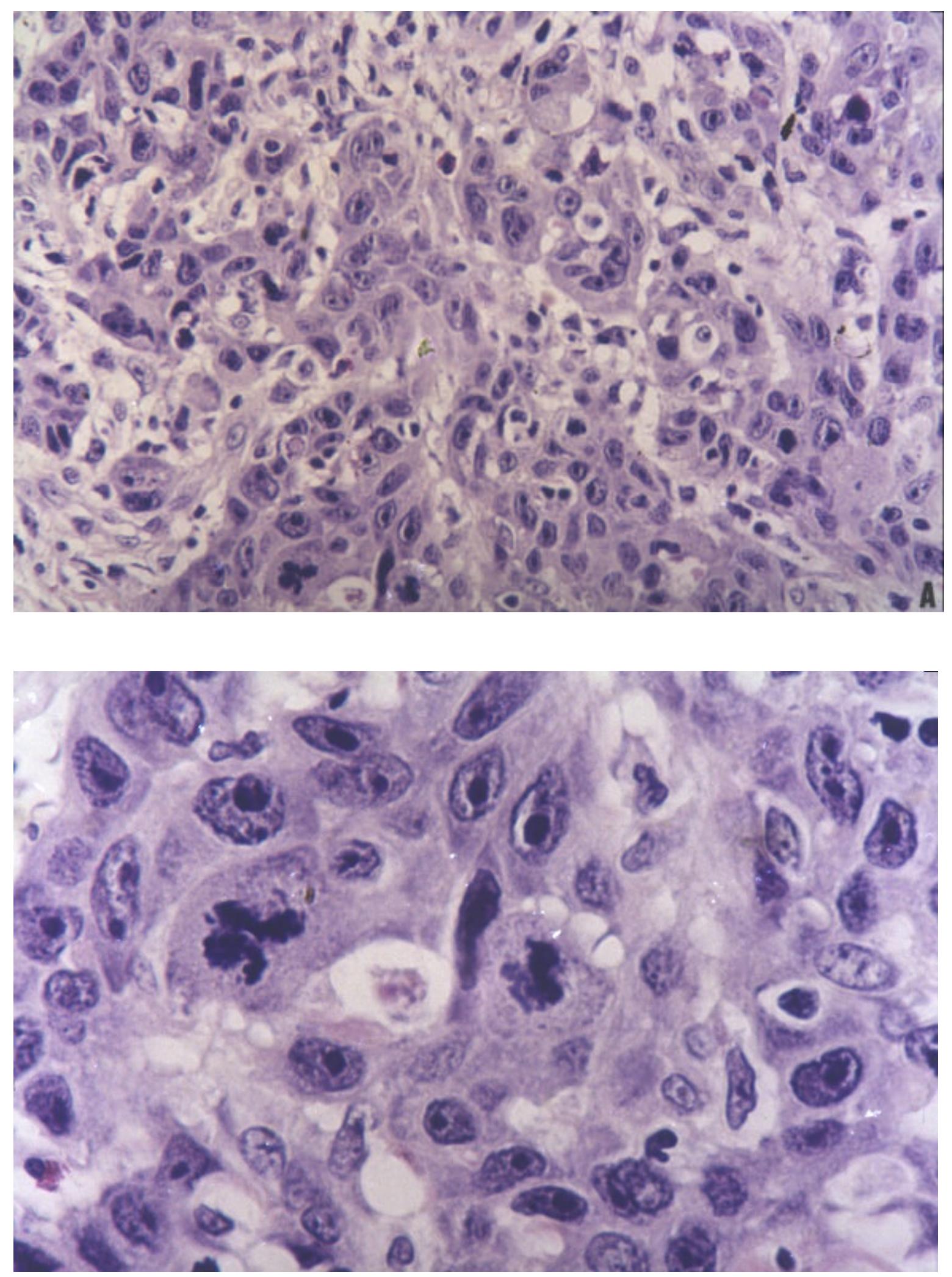

FIGURA 9 - Observar a atipia celular caracterizada por intenso pleomorfismo, hipercromatismo e numerosas figuras de mitoses atípicas. (HE, aumento original $A=400 \mathrm{x}$ e $\mathrm{B}=1000 \mathrm{x}$ ) 

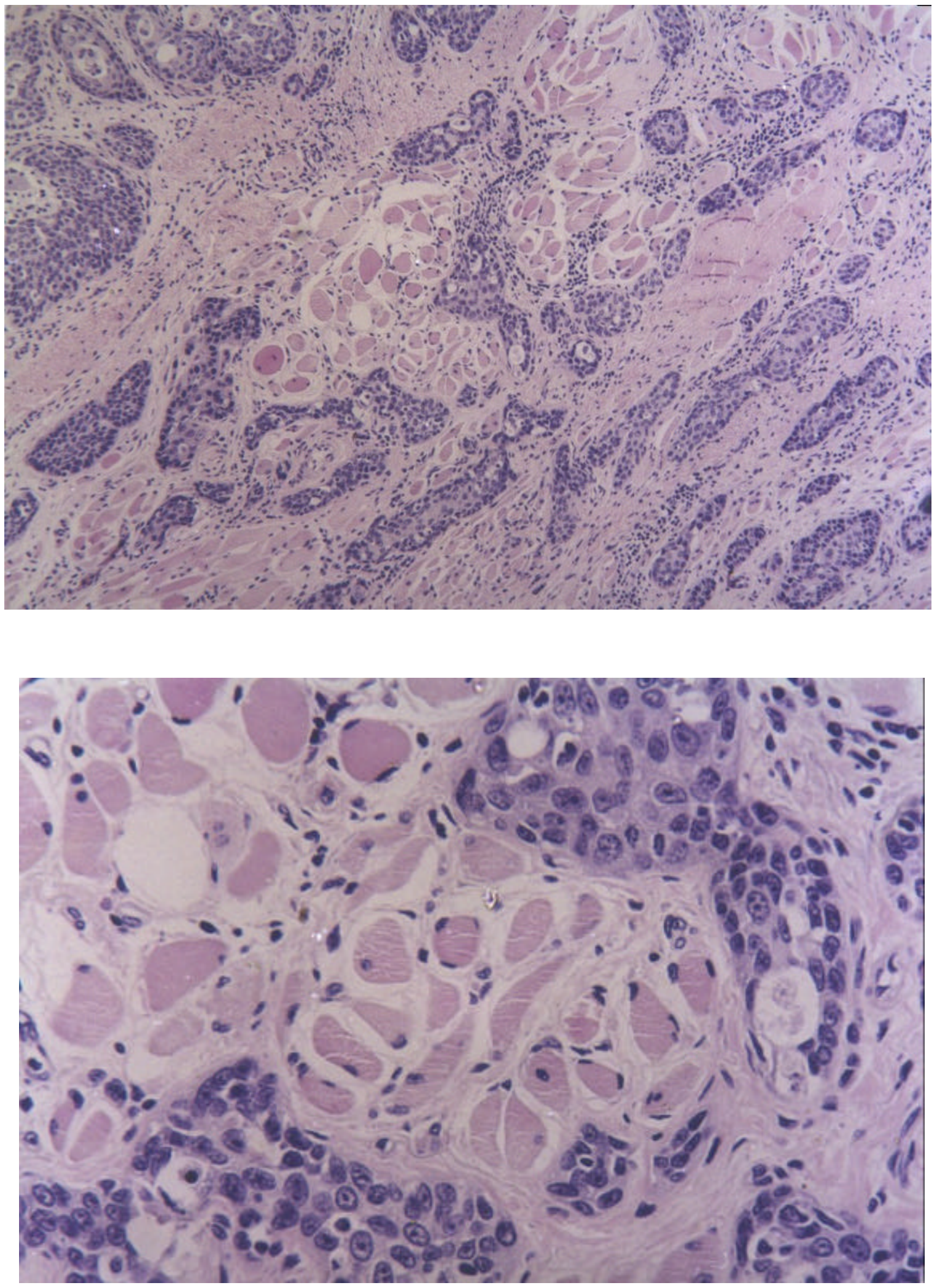

FIGURA 10 - Invasão do plano muscular pelos cordões e ilhotas tumorais do CEC (A e B). (HE, aumento original $\mathrm{A}=100 \mathrm{x}$ e $\mathrm{B}=400 \mathrm{x}$ ) 

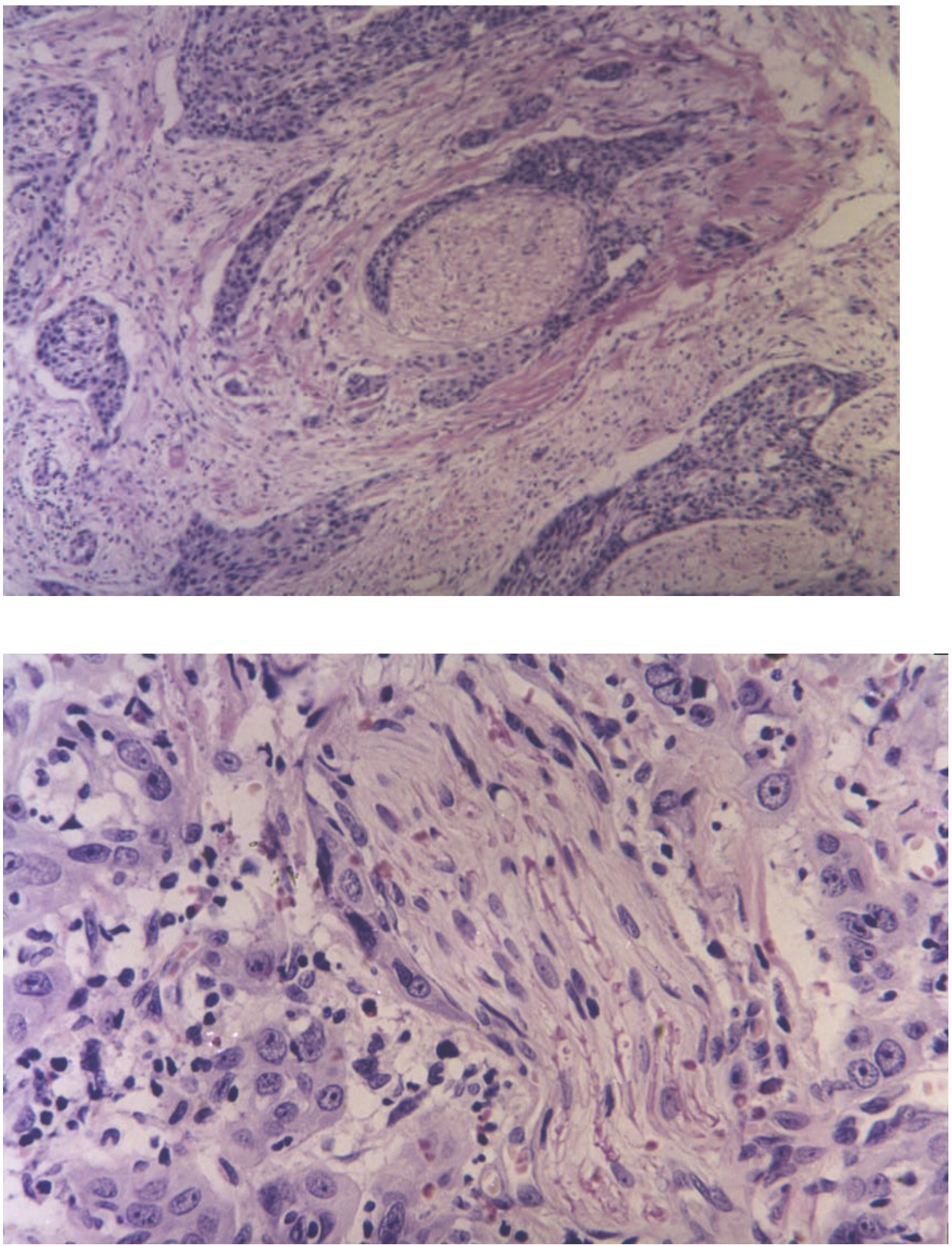

FIGURA 11 - Infiltração perineural pelo $\operatorname{CEC}$ (A e B). (HE, aumento original $A=100 x$ e $\mathrm{B}=40 \mathrm{x}$ ) 


\subsection{Análise imuno-histoquímica dos carcinomas}

Baseado nos valores medianos de marcação dos anticorpos PCNA e p53 nos dois grupos analisados (CEB e CEC), os resultados foram dicotomizados. As marcações para o anticorpo PCNA detectadas em um valor me nor ou igual a $60 \%$ foram observadas em $35,3 \%$ dos carcinomas escamosos basalóides e em 59,3\% dos carcinomas espinocelulares pouco diferenciados. A marcação superior a $60 \%$ de células PCNA-positivas foi verificada em 64,7\% dos carcinomas escamosos basalóides e em 40,7\% dos carcinomas espinocelulares pouco diferenciados (Tabela 9 e Figuras 12A, 12B e 13A, 13B).

Os valores dicotomizados para a porcentagem de células p53-positivas revelaram que 58,8\% dos carcinomas escamosos basalóides apresentaram uma porcentagem menor ou igual a $23 \%$ de células tumorais positivas e que $44,5 \%$ dos carcinomas espinocelulares pouco diferenciados apresentaram este índice de marcação. Marcações imunopositivas ao anticorpo p53 maiores que $23 \%$ foram detectadas em $41,2 \%$ dos carcinomas escamosos basalóides e 55,5\% dos carcinomas espinocelulares pouco diferenciados (Tabela 9 e Figuras 14A, 14B e 15A, 15B). 
TABELA 9 - Distribuição da expressão imuno-histoquímica dos anticorpos PCNA e p53 nos carcinomas escamosos basalóides e nos carcinomas espinocelulares pouco diferenciados de boca. Hospital do Câncer, São Paulo, 1970 a 2000

\begin{tabular}{|c|c|c|c|c|c|}
\hline \multirow{3}{*}{ Variável } & \multicolumn{4}{|c|}{ Grupo } & \multirow{3}{*}{$p^{*}$} \\
\hline & \multicolumn{2}{|c|}{ CEB } & \multicolumn{2}{|c|}{ CEC } & \\
\hline & $\mathrm{N}^{\mathrm{o}}$ & $\%$ & $\mathrm{~N}^{\mathrm{O}}$ & $\%$ & \\
\hline \multicolumn{6}{|l|}{ PCNA } \\
\hline $60 \%$ positividade & 6 & 35,3 & 16 & 59,3 & 0,215 \\
\hline$>60 \%$ positividade & 11 & 64,7 & 11 & 40,7 & \\
\hline \multicolumn{6}{|l|}{ p53 } \\
\hline $23 \%$ positividade & 10 & 58,8 & 12 & 44,5 & 0,537 \\
\hline$>23 \%$ positividade & 7 & 41,2 & 15 & 55,5 & \\
\hline TOTAL & 17 & 100,0 & 27 & 100,0 & \\
\hline
\end{tabular}

CEB: Carcinoma Escamoso Basalóide, CEC: Carcinoma Espinocelular Pouco Diferenciado $p^{*}$ : nível descritivo do teste exato de Fisher

A expressão citoplasmática do anticorpo Bax, avaliada pelo sistema de escore demonstrou que $88,2 \%$ dos carcinomas escamosos basalóides e 52,4\% dos carcinomas espinocelulares pouco diferenciados apresentaram um padrão de marcação forte (Figuras 16A, 16B e 17A, 17B). Apenas em 28,6\% dos carcinomas espinocelulares pouco diferenciados, o padrão de marcação citoplasmática foi fraco. Em 11,8\% dos carcinomas escamosos basalóides e em $19,0 \%$ dos carcinomas espinocelulares pouco diferenciados a imunomarcação foi negativa (Tabela 10).

A forte expressão citoplasmática do anticorpo Bcl-X, foi visualizada em $94,1 \%$ dos carcinomas escamosos basalóides e em 96,2\% dos carcinomas espinocelulares pouco diferenciados (Figuras 18A, 18B e 19A, 19B). Apenas um carcinoma escamoso basalóide $(5,9 \%)$ e um carcinoma espinocelular pouco diferenciado, $3,8 \%$, apresentaram um padrão de marcação citoplasmática fraca ao Bcl-X (Tabela 10). 
A expressão das proteínas Bcl X e Bax foi verificada, respectivamente, em 88,2\% dos pacientes com carcinoma escamoso basalóide e em $81 \%$ dos pacientes com carcinoma espinocelular pouco diferenciado. Não verificamos diferença quanto à proporção de células positivas e negativas a estas proteínas, entre os dois grupos tumorais analisados.

TABELA 10 - Distribuição da expressão imuno-histoquímica dos anticorpos Bax e Bcl X nos carcinomas escamosos basalóides e nos carcinomas espinocelulares pouco diferenciados de boca. Hospital do Câncer, São Paulo, 1970 a 2000

\begin{tabular}{|c|c|c|c|c|c|}
\hline \multicolumn{6}{|c|}{ Grupo } \\
\hline \multirow{2}{*}{ Variável } & \multicolumn{2}{|c|}{ CEB } & \multicolumn{2}{|c|}{ CEC } & \multirow{2}{*}{$p^{*}$} \\
\hline & $\mathrm{N}^{\mathrm{o}}$ & $\%$ & $\mathrm{~N}^{\mathrm{O}}$ & $\%$ & \\
\hline \multicolumn{6}{|l|}{$\overline{\text { Bax }}$} \\
\hline 0 & 2 & 11,8 & 4 & 19,0 & \\
\hline 1 & - & - & 6 & 28,6 & 0,031 \\
\hline 2 & 15 & 88,2 & 11 & 52,4 & \\
\hline
\end{tabular}

Bcl-X

\begin{tabular}{cccccc}
0 & - & - & - & - & \\
1 & 1 & 5,9 & 1 & 3,8 & 0,640 \\
2 & 16 & 94,1 & 25 & 96,2 & \\
\hline TOTAL & 17 & 100,0 & 27 & 100,0 & \\
\hline \hline
\end{tabular}

CEB: Carcinoma Escamoso Basalóide, CEC: Carcinoma Espinocelular Pouco Diferenciado $0=$ imunomarcação negativa, $1=$ imunomarcação fraca, $2=$ imunomarcação forte $p^{*}$ : nível descritivo do teste qui-quadrado 

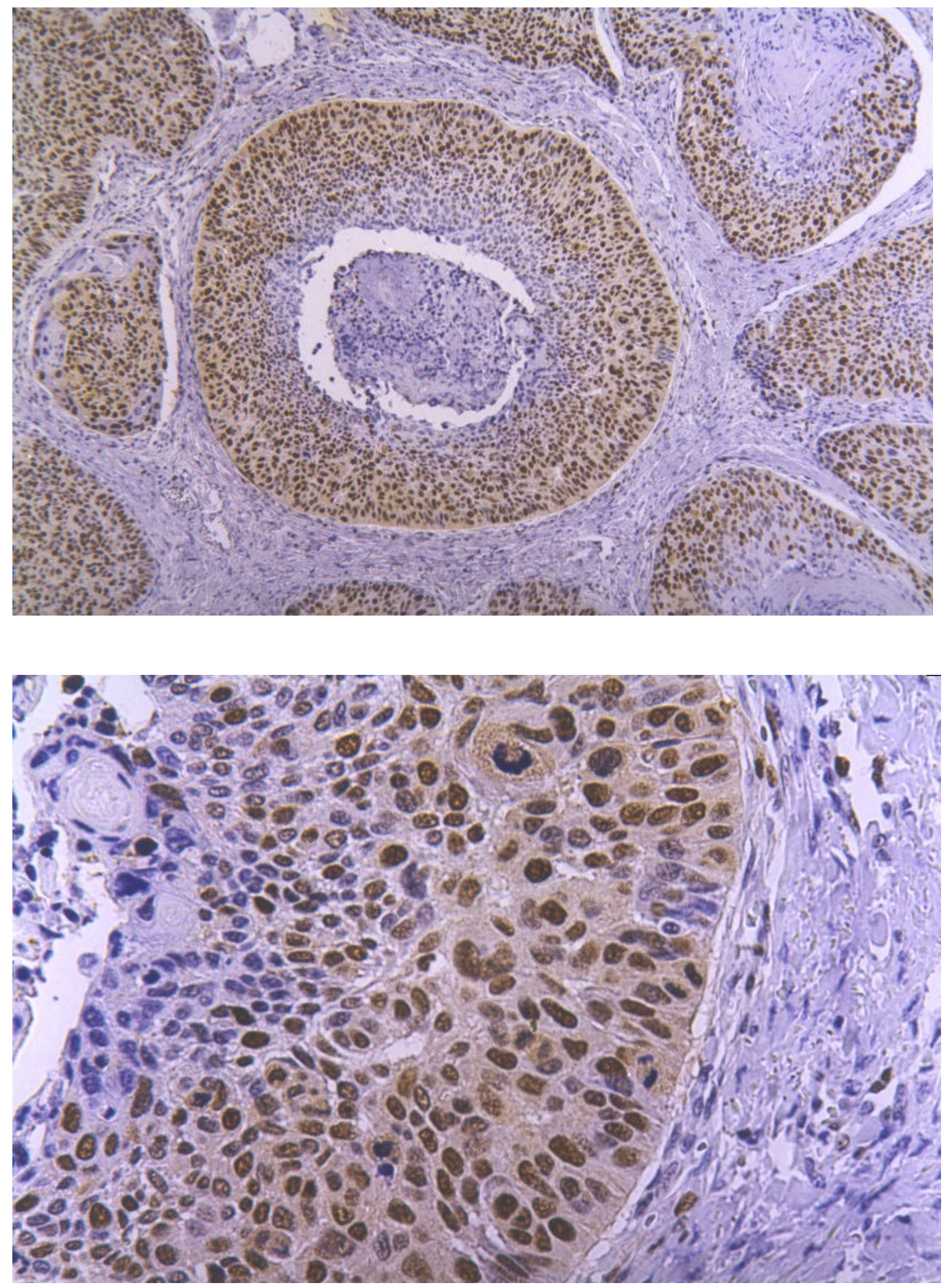

FIGURA 12 - Imunoexpressão do PCNA no CEB (A e B). Observar a imunopositividade nas ilhotas tumorais, exceto nas células neoplásicas centrais próximas à comedonecrose. (IHQ, aumento original $\mathrm{A}=50 \mathrm{x}$ e $\mathrm{B}=100 \mathrm{x}$ ) 

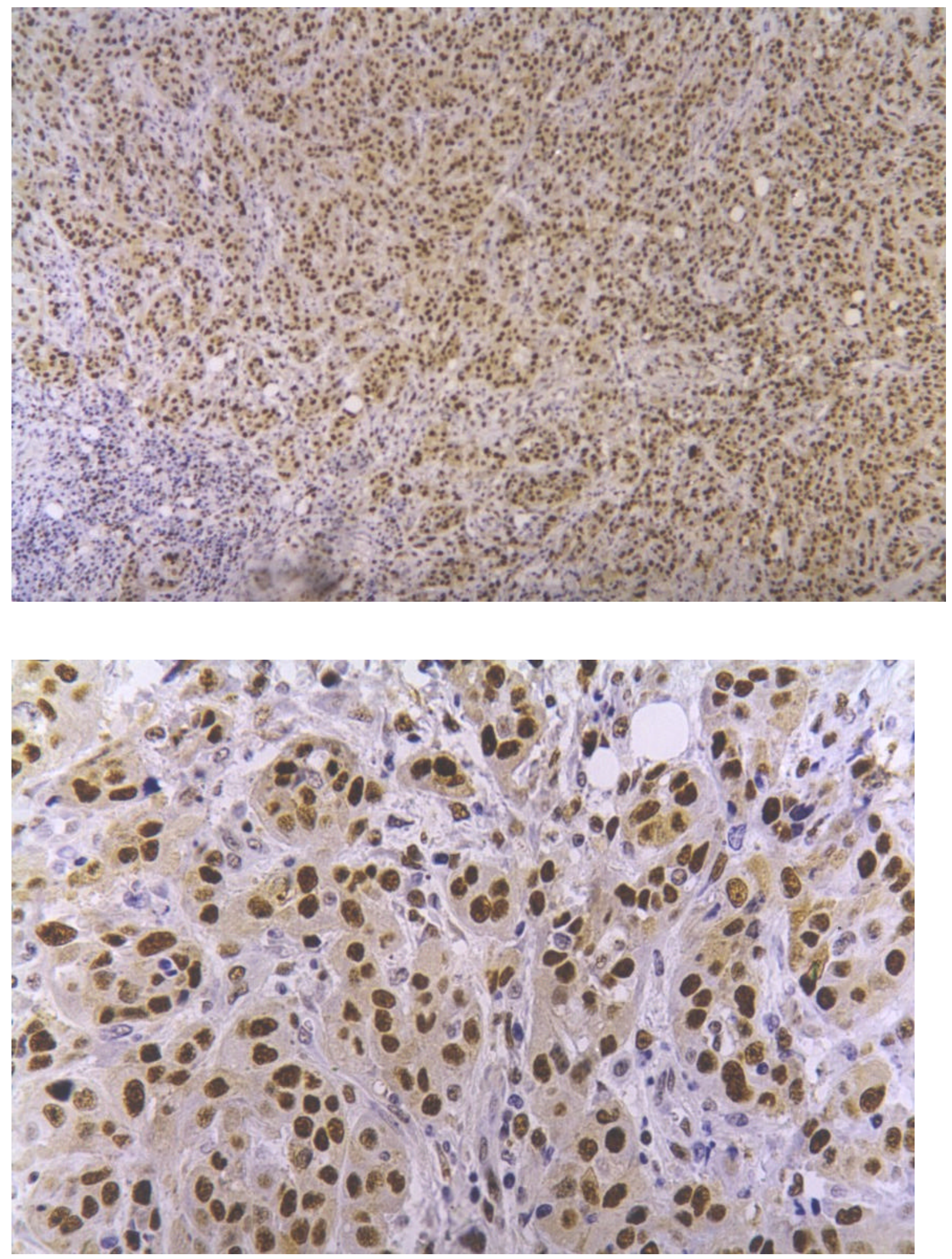

FIGURA 13 - Imunoexpressão do PCNA no CEC (A e B). A intensa imunopositividade ao PCNA foi observada na maioria das células neoplásicas pouco diferenciadas. (IHQ, aumento original $A=100 x$ e $B=400 x$ ) 

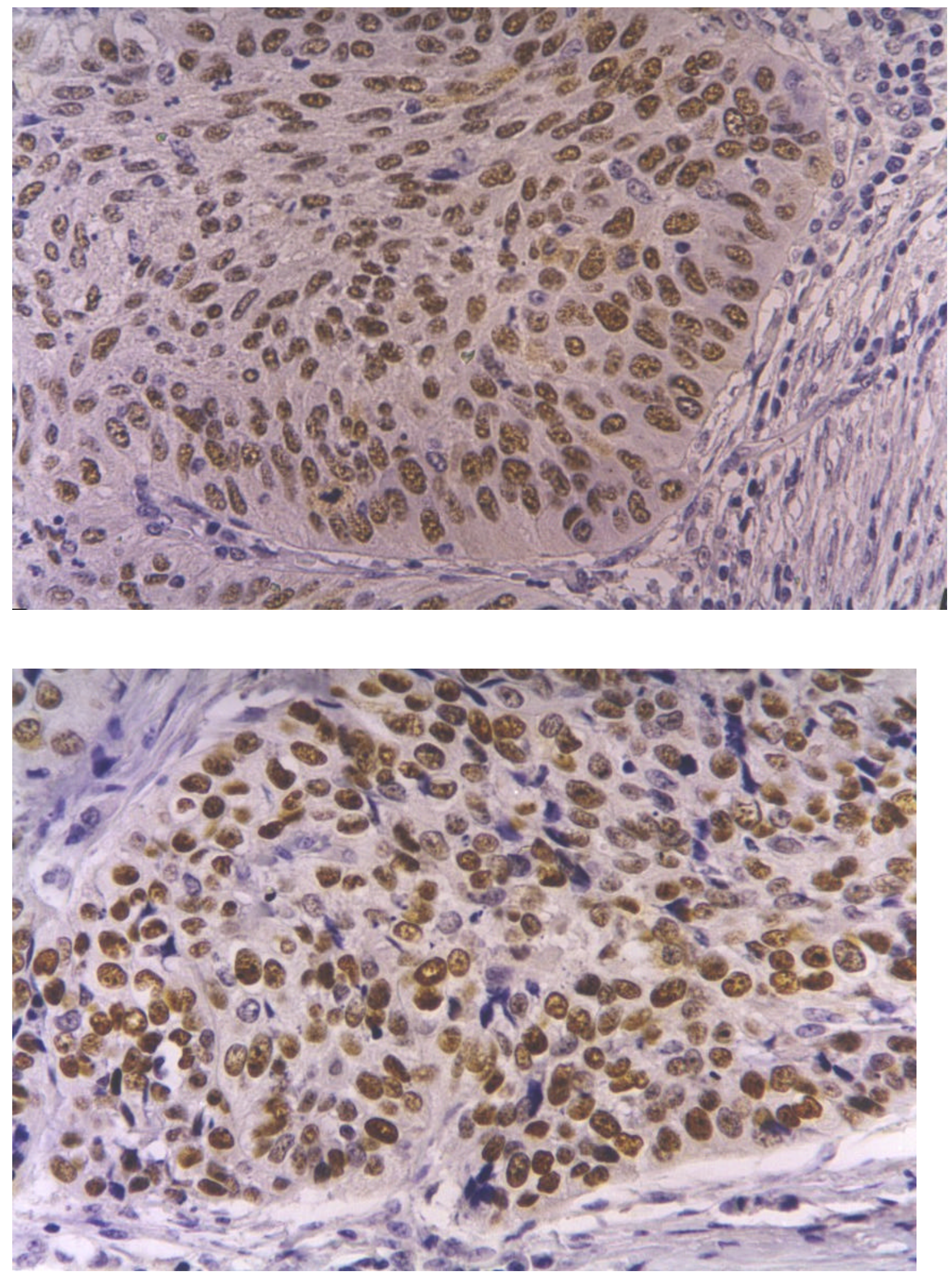

FIGURA 14 - Imunoexpressão da proteína p53 no CEB (A e B). Observar a imunopositividade das células basalóides à proteína p53. (IHQ, aumento original $A$ e $B=400 x$ ) 

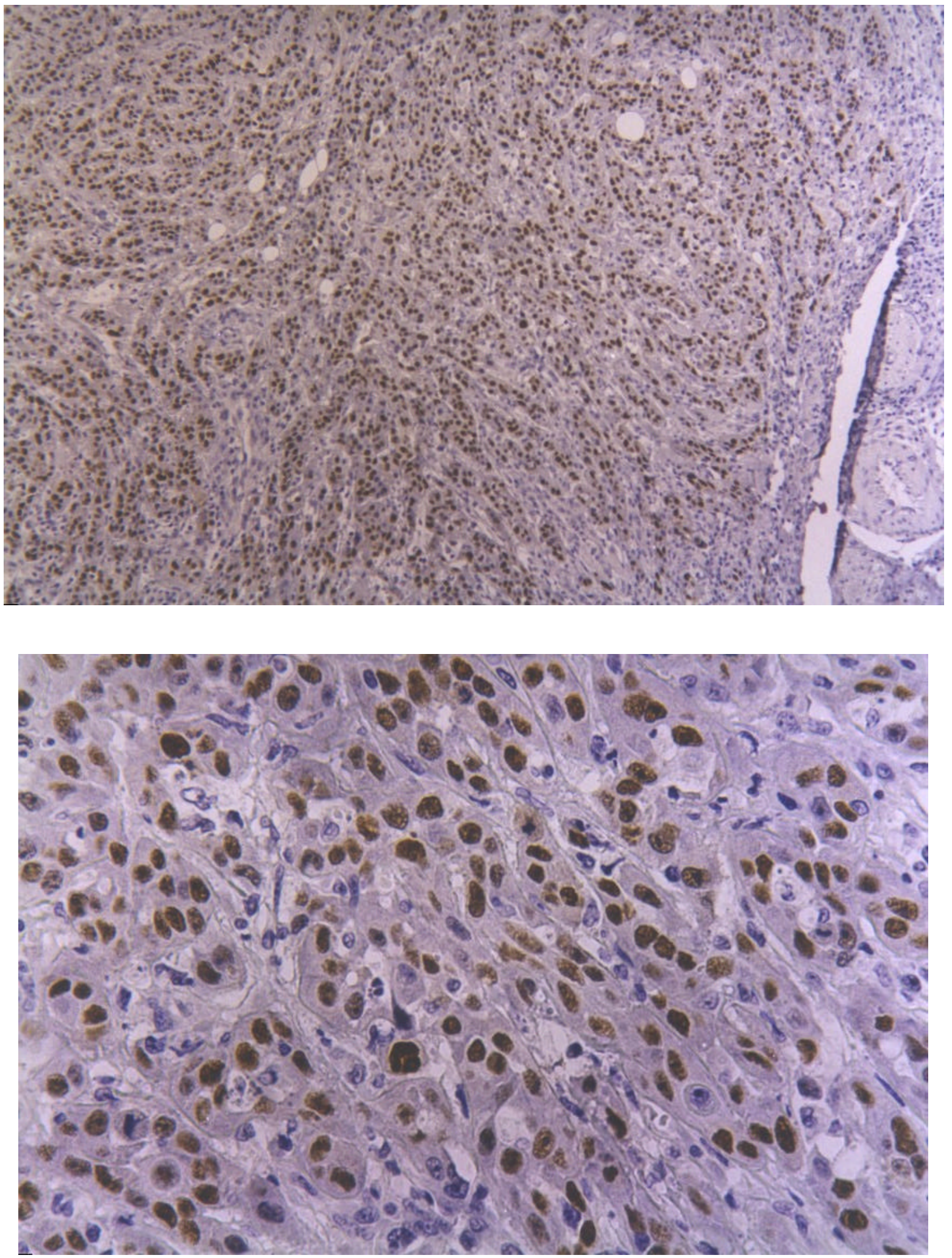

FIGURA 15 - Imunoexpressão da proteína p53 no CEC (A e B). Em destaque a intensa imunopositividade ao p53 das células neoplásicas pouco diferenciadas. (IHQ, aumento original $\mathrm{A}=100 \mathrm{x}$ e $\mathrm{B}=400 \mathrm{x}$ ) 

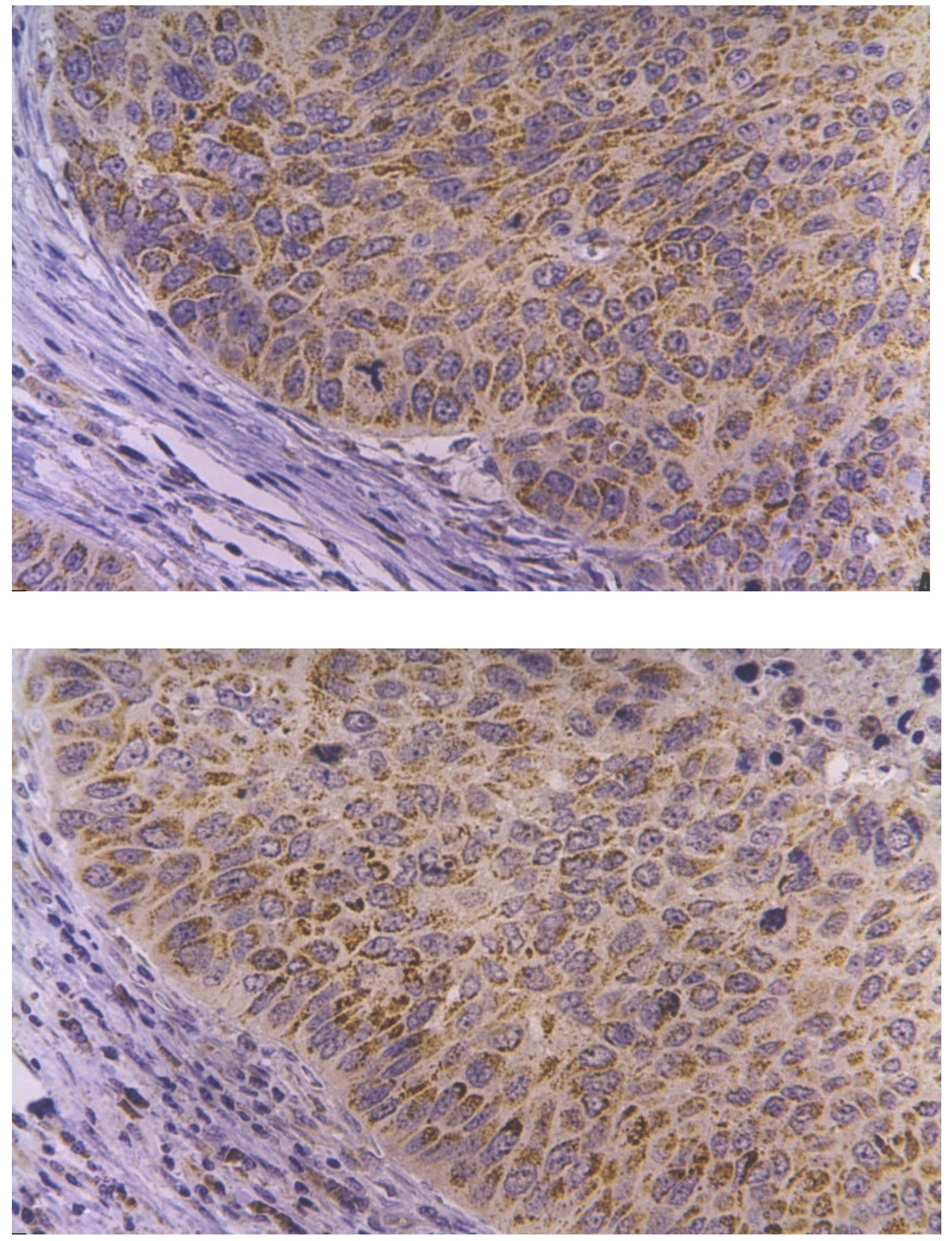

FIGURA 16 - Imunoexpressão de Bax no CEB (A e B). A expressão da proteína Bax foi observada intensamente no citoplasma das células basalóides (IHQ, aumento original $\mathrm{A}$ e $\mathrm{B}=400 \mathrm{x}$ ) 

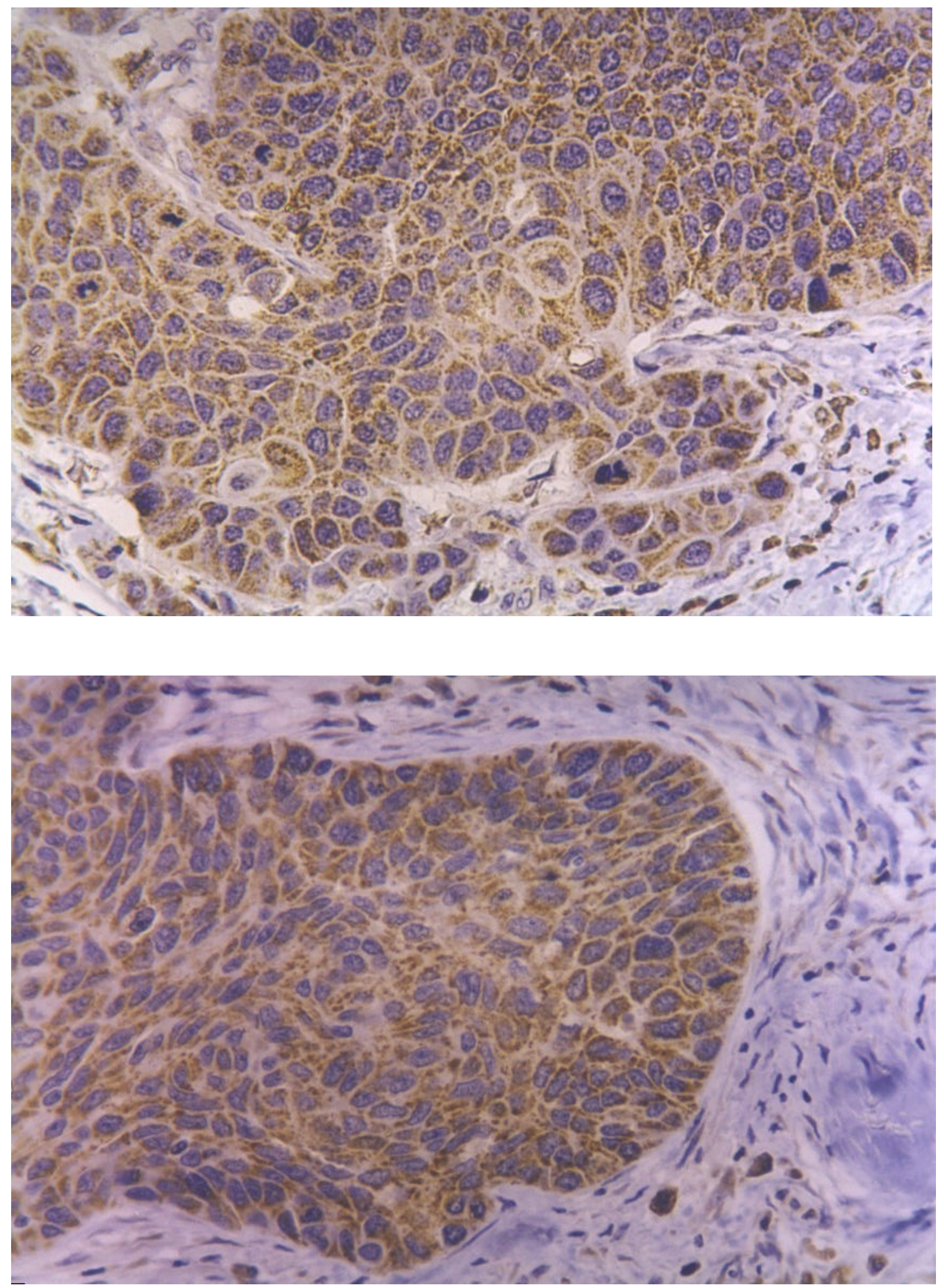

FIGURA 17 - Expressão citoplasmática intensa da proteína Bax observada no CEC. (A e B) (IHQ, aumento original A e B=400x) 

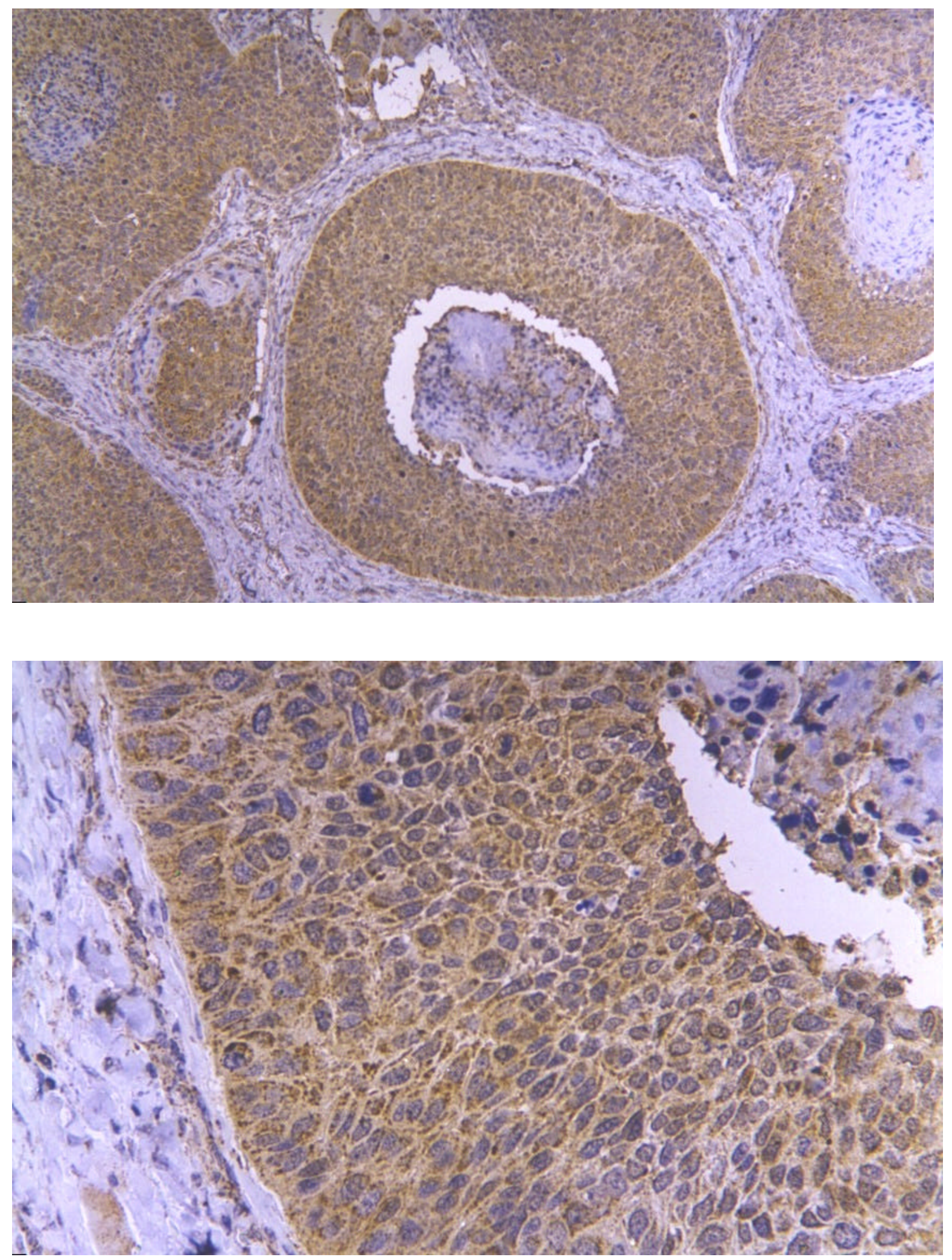

FIGURA 18 - Imunoexpressão de BclX no CEB (A e B). A expressão da proteína Bcl-X foi observada intensamente no citoplasma das células basalóides. (IHQ, aumento original $\mathrm{A}$ e $\mathrm{B}=400 \mathrm{x}$ ) 

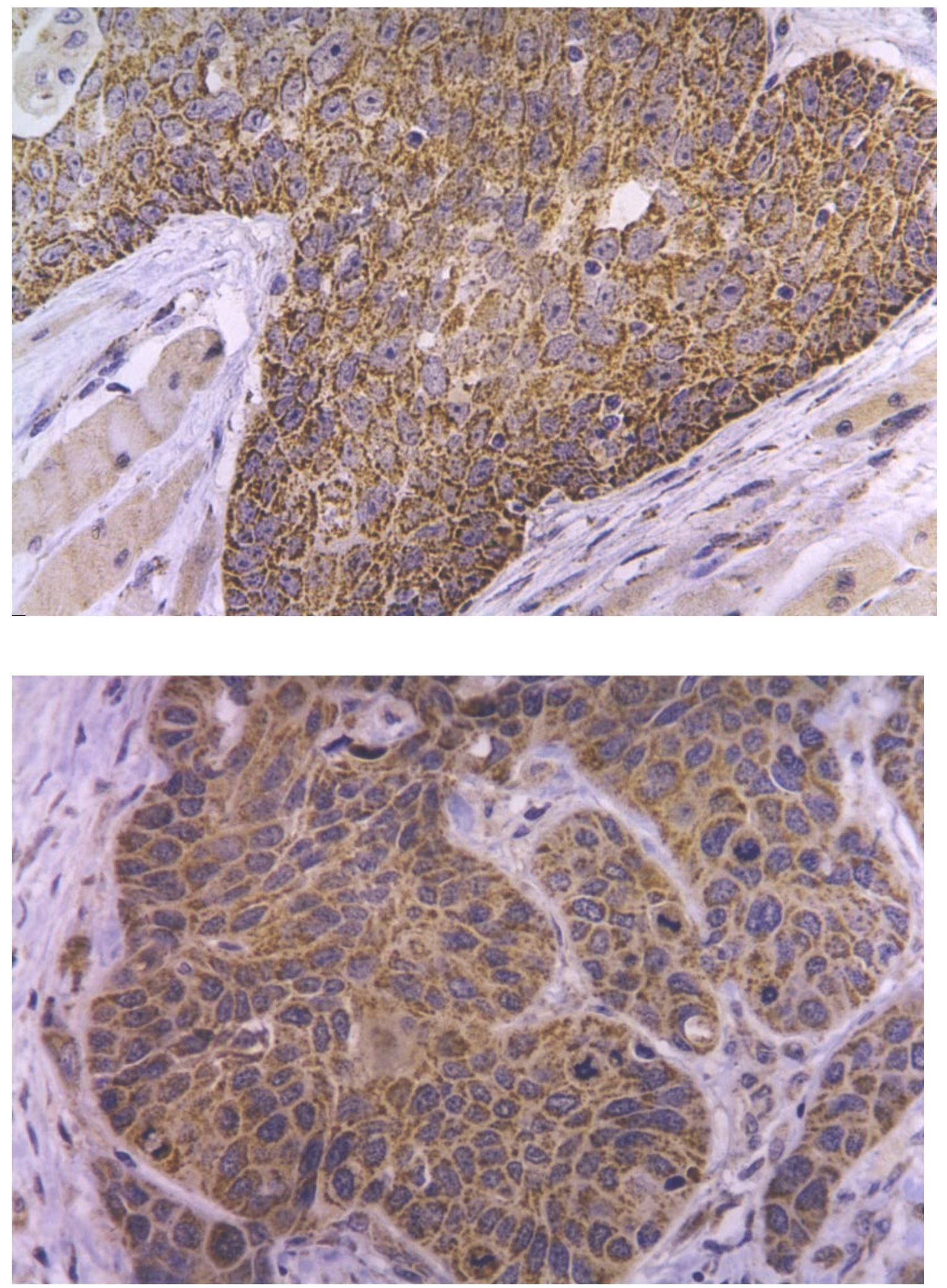

FIGURA 19 - Imunoexpressão de BclX no CEC (A e B). A expressão da proteína Bcl-X foi observada intensamente no citoplasma das células escamosas. (IHQ, aumento original $\mathrm{A}$ e $\mathrm{B}=400 \mathrm{x}$ ) 


\subsection{Análise estatística}

Não se detectou diferença estatística entre as médias das idades dos pacientes dos dois grupos tumorais analisados (CEB e CEC).

Nenhuma diferença estatística foi identificada através do teste exato de Fisher entre os pacientes com carcinoma escamoso basalóide e carcinoma espinocelular pouco diferenciado na mucosa bucal na análise das seguintes variáveis:

$\checkmark \quad$ características demográficas (gênero, raça, idade);

$\checkmark \quad$ história clínica (tabagismo, etilismo) e características clínicas (T, N, estádio clínico, tipo de lesão);

$\checkmark \quad$ tratamento (esvaziamento cervical, radioterapia, quimioterapia) e evolução (recidiva local, regional, metástases a distância, segundo tumor primário);

$\checkmark \quad$ características microscópicas do infiltrado inflamatório, infiltração muscular, óssea e margens cirúrgicas;

$\checkmark \quad$ marcações pelos anticorpos PCNA e p53;

$\checkmark \quad$ proporção das proteínas Bcl-X/Bax.

Não foi observada diferença estatística pelo teste de freqüências do qui-quadrado, entre os carcinomas escamosos basalóides e os carcinomas espinocelulares pouco diferenciados, quanto à localização dos tumores e quanto à expressão do anticorpo Bcl-X. 
Observou-se diferença estatística, pelo teste exato de Fisher, quanto à embolização angiolinfática $(p=0,025)$ e infiltração perineural $(p=0,012)$ e diferença estatística marginal referente ao padrão de invasão tumoral $(p=0,055)$ entre os grupos CEB e CEC.

Verificourse diferença estatisticamente significativa, pelo teste qui-quadrado, entre os grupos CEB e CEC, quanto à expressão do anticorpo $\operatorname{Bax}(p=0,031)$.

Não foi identificada associação, pelo teste qui-quadrado, entre a expressão da proteína p53 e dos marcadores PCNA, Bax e Bcl X, nos grupos tumorais estudados.

\subsubsection{Análise de sobrevida}

O período de seguimento dos pacientes do grupo CEB variou de 3-168 meses (média 56 meses, desvio padrão 47) e para o grupo CEC variou de 1-187 meses (média 36 meses, desvio padrão 42 meses). Ao final do estudo, em fevereiro de 2002, três pacientes $(17,6 \%$ ) do grupo CEB estavam vivos, sem evidências de recidiva da doença, um paciente $(5,9 \%)$ estava vivo com a doença, oito pacientes $(47,0 \%)$ faleceram em decorrência do tumor primário, quatro pacientes $(23,5 \%)$ morreram por outras causas não relacionadas ao câncer, um paciente foi considerado perdido de vista. No grupo CEC, apenas um paciente $(3,7 \%)$ apresentava-se vivo, comprometido pela doença, 14 pacientes $(51,8 \%)$ faleceram em decorrência do tumor primário, 11 pacientes $(40,7 \%)$ morreram por outras causas não relacionadas ao câncer e dois pacientes foram considerados perdidos de vista.

As probabilidades de sobrevida global, sobrevida especifica e sobrevida livre de doença, acumuladas em 5 e 10 anos, foram calculadas pelo estimador produto-limite de Kaplan-Meier. A comparação entre as curvas de sobrevida global, sobrevida específica e 
sobrevida livre de doença, realizadas através do teste de log-rank não apresentaram diferenças estatisticamente significativas entre os grupos CEB e CEC.

Também não se detectou diferença estatística entre as probabilidades de sobrevida global, sobrevida específica e sobrevida livre de doença, quanto às marcações pelos anticorpos PCNA, p53, Bax e Bcl-X para os pacientes com CEB e CEC.

As Tabelas 11, 12 e 13 e as Figuras 1, 2 e 3 apresentam, respectivamente as probabilidades de sobrevida global, sobrevida específica e sobrevida livre de doença acumuladas em 5 e 10 anos.

TABELA 11 - Análise de sobrevida global. Probabilidade de sobrevida acumulada pela técnica de Kaplan-Meier

\begin{tabular}{|c|c|c|c|}
\hline & & $\overline{\text { bal }}$ & \\
\hline Variável & $\begin{array}{c}5 \text { anos } \\
(\%)\end{array}$ & $\begin{array}{c}10 \text { anos } \\
(\%)\end{array}$ & $p^{*}$ \\
\hline Grupo & & & \\
\hline CEB & 46,7 & 20,8 & 0,093 \\
\hline CEC & 18,2 & 13,6 & \\
\hline PCNA & & & \\
\hline$\leq 60 \%$ positividade & 21,8 & 0,0 & 0,296 \\
\hline$>60 \%$ positividade & 35,7 & 15,3 & \\
\hline p53 & & & \\
\hline$\leq 23 \%$ positividade & 25,2 & 16,8 & 0,774 \\
\hline$>23 \%$ positividade & 31,8 & 17,0 & \\
\hline Bax & & & \\
\hline 0 & 33,3 & 33,3 & \\
\hline 1 & 16,7 & 0,0 & 0,785 \\
\hline 2 & 38,1 & 17,8 & \\
\hline Bcl-X & & & \\
\hline 1 & 50,0 & - & 0,831 \\
\hline 2 & 28,6 & - & \\
\hline
\end{tabular}




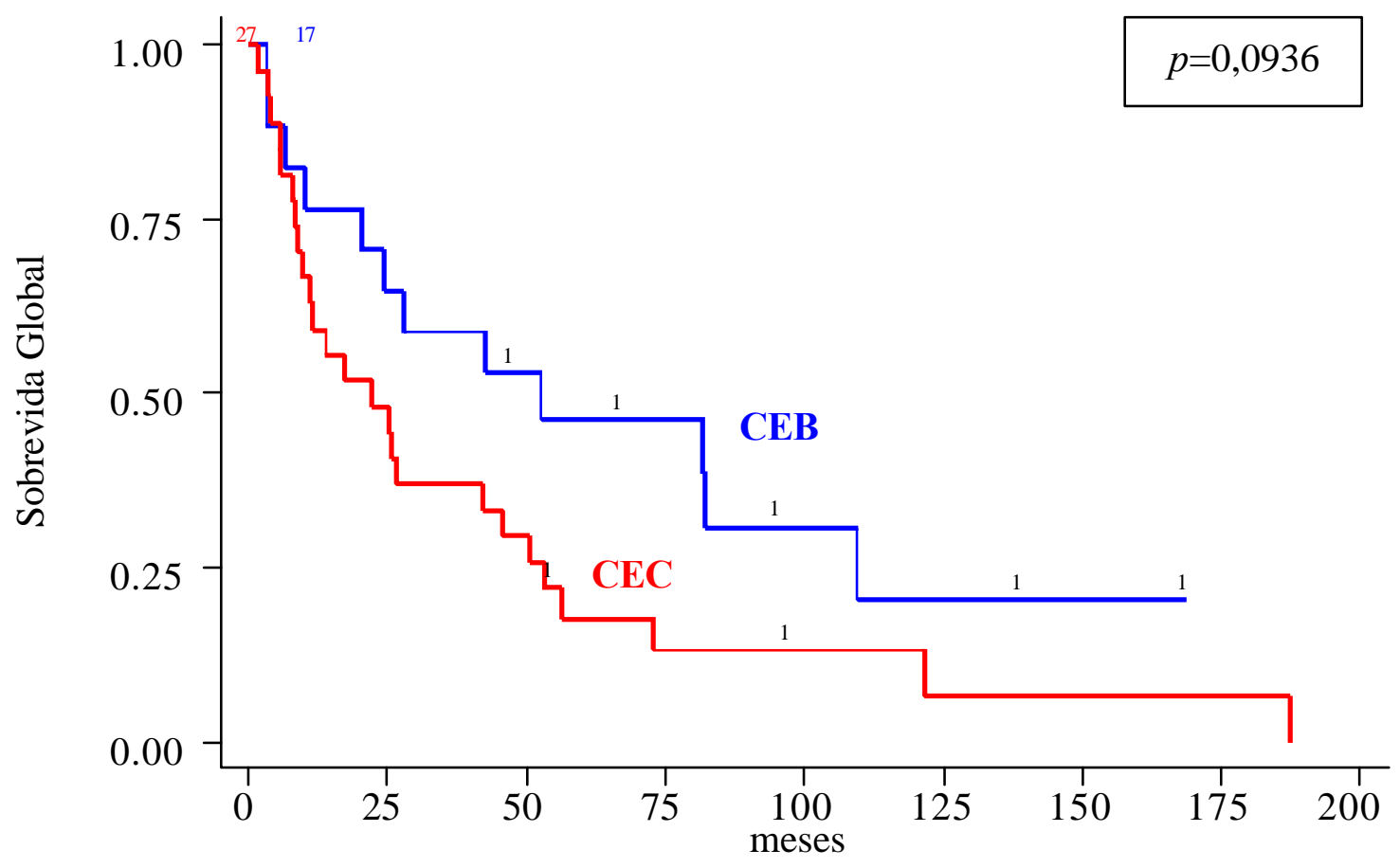

FIGURA 20 - Sobrevida global dos pacientes com carcinoma escamoso basalóide e com carcinoma espinocelular pouco diferenciado de boca. Porcentagem de sobrevida acumulada pela técnica de Kaplan-Meier. 
TABELA 12 - Análise de sobrevida específica. Probabilidade de sobrevida acumulada pela técnica de Kaplan-Meier

\begin{tabular}{|c|c|c|c|}
\hline \multirow{2}{*}{ Variável } & \multicolumn{2}{|c|}{ Sobrevida Específica } & \multirow[b]{2}{*}{$p^{*}$} \\
\hline & $\begin{array}{c}5 \text { anos } \\
(\%)\end{array}$ & $\begin{array}{c}10 \text { anos } \\
(\%)\end{array}$ & \\
\hline \multicolumn{4}{|l|}{ Grupo } \\
\hline CEB & 50,2 & 50,2 & 0,368 \\
\hline CEC & 36,7 & 27,5 & \\
\hline \multicolumn{4}{|l|}{ PCNA } \\
\hline $60 \%$ positividade & 38,3 & 38,3 & 0,526 \\
\hline$>60 \%$ positividade & 47,7 & 39,8 & \\
\hline \multicolumn{4}{|l|}{ p53 } \\
\hline $23 \%$ positividade & 44,2 & 44,2 & 0,593 \\
\hline$>23 \%$ positividade & 41,5 & 35,1 & \\
\hline \multicolumn{4}{|l|}{ Bax } \\
\hline 0 & 77,8 & 77,8 & \\
\hline 1 & 44,4 & 44,4 & 0,659 \\
\hline 2 & 42,2 & 36,2 & \\
\hline \multicolumn{4}{|l|}{ Bcl-X } \\
\hline 1 & 100,0 & 100,0 & 0,329 \\
\hline 2 & 42,3 & 37,6 & \\
\hline
\end{tabular}

CEB: Carcinoma Escamoso Basalóide, CEC: Carcinoma Espinocelular $\overline{\overline{\text { Pouco Diferenciado }}}$ $p^{*}$ : nível descritivo do teste log-rank 


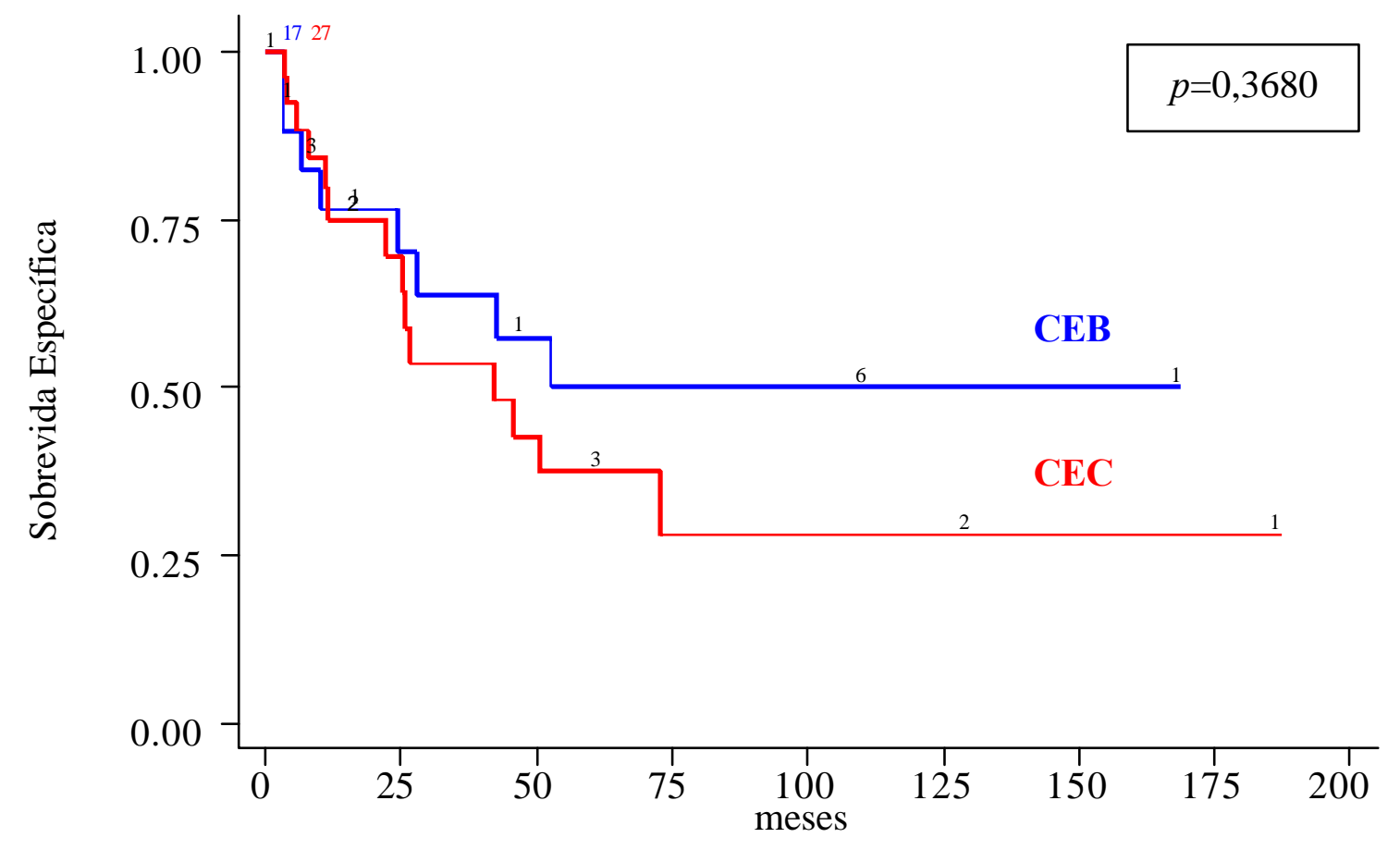

FIGURA 21 - Sobrevida específica dos pacientes com carcinoma escamoso basalóide e com carcinoma espinocelular pouco diferenciado de boca. Porcentagem de sobrevida acumulada pela técnica de Kaplan-Meier. 
TABELA 13 - Análise de sobrevida livre de doença. Probabilidade de sobrevida acumulada pela técnica de Kaplan-Meier

\begin{tabular}{|c|c|c|c|}
\hline \multirow{2}{*}{ Variável } & \multicolumn{2}{|c|}{ Sobrevida Livre de Doença } & \multirow[b]{2}{*}{$p^{*}$} \\
\hline & $\begin{array}{c}5 \text { anos } \\
(\%)\end{array}$ & $\begin{array}{c}10 \text { anos } \\
(\%)\end{array}$ & \\
\hline \multicolumn{4}{|l|}{ Grupo } \\
\hline CEB & 39,6 & 39,6 & 0,648 \\
\hline CEC & 36,9 & 24,6 & \\
\hline \multicolumn{4}{|l|}{ PCNA } \\
\hline $60 \%$ positividade & 30,0 & 30,0 & 0,220 \\
\hline$>60 \%$ positividade & 45,3 & 37,7 & \\
\hline \multicolumn{4}{|l|}{ p53 } \\
\hline $23 \%$ positividade & 42,4 & 42,4 & 0,334 \\
\hline$>23 \%$ positividade & 34,0 & 27,2 & \\
\hline \multicolumn{4}{|l|}{ Bax } \\
\hline 0 & 55,5 & 55,5 & \\
\hline 1 & 50,0 & 50,0 & 0,780 \\
\hline 2 & 35,6 & 29,6 & \\
\hline \multicolumn{4}{|l|}{ Bcl-X } \\
\hline 1 & 100,0 & 100,0 & 0,247 \\
\hline 2 & 36,8 & 31,6 & \\
\hline
\end{tabular}

$\overline{\text { CEB: Carcinoma Escamoso Basalóide, CEC: Carcinoma Espinocelular }} \overline{\overline{\text { Pouco Diferenciado }}}$ $p^{*}$ : nível descritivo do teste log-rank 


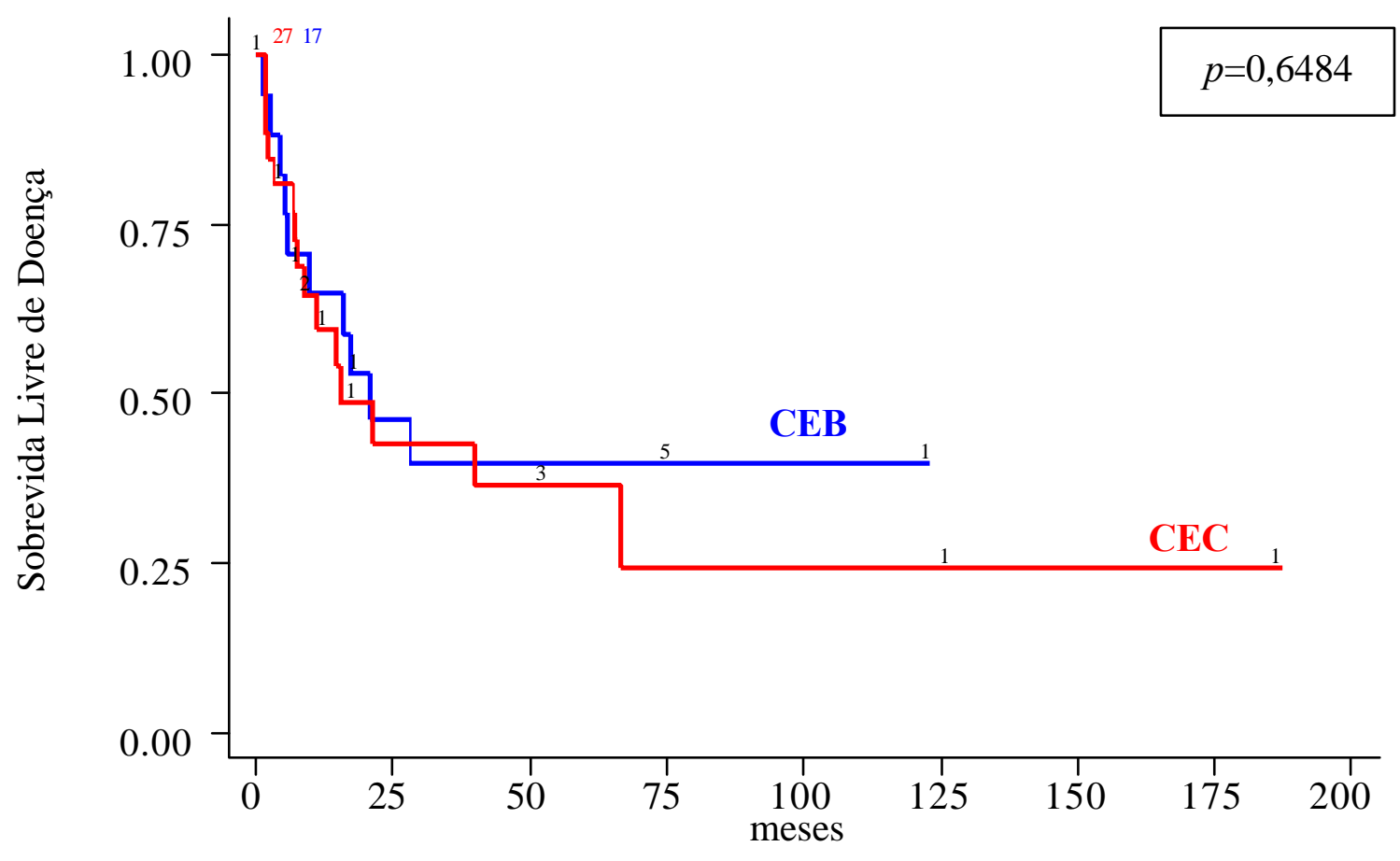

FIGURA 22 - Sobrevida livre de doença dos pacientes com carcinoma escamoso basalóide e com carcinoma espinocelular pouco diferenciado de boca. Porcentagem de sobrevida acumulada pela técnica de Kaplan-Meier. 
Observou-se que, embora a marcação da proteína Bax, tenha sido significativa no teste de freqüências entre os grupos CEB e CEC, a comparação entre as curvas de sobrevida específica não apresentou diferença estatisticamente significativa pelo teste log-rank (Tabela $11)$.

Devido à pequena casuística em cada grupo (CEB e CEC), realizou-se a análise multivariada para todos os carcinomas (44 casos). O modelo de regressão de Cox foi realizado para a sobrevida específica, através da técnica "stepwise", com nível de significância igual a $10 \%$.

Todas as variáveis de interesse foram incluídas na análise multivariada, com exclusão baseada no nível de significância de $10 \%$ e a partir deste processo verificamos que a única variável significativa foi a presença de metástase em linfonodos regionais $(\mathrm{N}+)$. Os pacientes com comprometimento linfonodal $(\mathrm{N}+)$ apresentaram um risco relativo de morte (RR) três vezes maior que os pacientes sem comprometimento linfonodal (N0) ( $p=0,051)$ (Tabela14).

TABELA 14 - Análise de sobrevida específica pelo modelo de Cox

\begin{tabular}{|c|c|c|c|}
\hline Va riável & $\mathbf{R} \mathbf{R}^{\#}$ & $\begin{array}{l}\text { Sobrevida Específica } \\
\text { IC }\end{array}$ & $p^{*}$ \\
\hline \multicolumn{4}{|l|}{$\mathbf{N}$} \\
\hline 0 & 1,0 & - & \\
\hline & & & 0,051 \\
\hline+ & 3,0 & $1,0-8,8$ & \\
\hline
\end{tabular}


6 DISCUSSÃ̃ 


\section{DISCUSSÃO}

O carcinoma escamoso basalóide tem sido considerado uma variante microscópica distinta, clinicamente mais agressiva do carcinoma espinocelular em vários sítios anatômicos ${ }^{1,30,34,38,42,79,107}$. Na laringe e hipofaringe, regiões da cabeça e pescoço mais comumente acometidas por esta neoplasia, as casuísticas são mais consistentes, permitindo o delineamento do comportamento biológico, clínico e até mesmo do prognóstico dos pacientes com carcinoma escamoso basalóide. Considerando sua recente descrição como uma entidade patológica distinta, esta neoplasia vem sendo pesquisada em diferentes localizações a partir de análises retrospectivas, sendo os casos de acometimento de mucosa bucal analisados juntamente com as demais regiões da cabeça e pescoço.

Muito embora, estudos sobre o comportamento biológico do carcinoma escamoso basalóide tenham sido realizados utilizando-se de técnicas como a imuno-histoquímica e a hibridização in situ, muitas controvérsias ainda persistem sobre sua evolução clínica e prognóstico. Devido a sua baixa ocorrência, principalmente, quando comparado ao carcinoma espinocelular, as amostras tumorais utilizadas por diversos autores ${ }^{13,34,58,68,92}$ têm incluído diferentes sítios anatômicos da cabeça e pescoço. Todavia, mesmo com um comportamento clínico similar, nas diferentes localizações, a anatomia local e/ou regional influencia a evolução tumoral afetando o prognóstico dos pacientes acometidos por esta neoplasia.

$\mathrm{Na}$ mucosa bucal, os primeiros relatos do carcinoma escamoso basalóide foram descritos no início da década de noventa, a partir dos trabalhos de CADIER et al. ${ }^{21}$ e LOVEJOY; MATHEW ${ }^{73}$, ambos publicados no ano de 1992, referindo-se, respectivamente, a carcinomas escamosos basalóides localizados na mucosa jugal e no palato. Até os dias atuais, 
identificamos na literatura aproximadamente, 30 carcinomas escamosos basalóide primários localizados exclusivamente na boca $3,7,9,10,21,22,24,25,26,43,50,52,73,92,132$. A real incidência desta neoplasia maligna em boca ainda é desconhecida, uma vez que as casuísticas são pequenas e os relatos clínicos são geralmente de casos isolados.

A preocupação inicial deste estudo foi, baseada nessa premissa, detectar os carcinomas escamosos basalóides localizados primariamente na boca, levando-se em consideração os critérios de exclusão descritos anteriormente, visando conhecer seu comportamento biológico e clínico nesta região. Ressaltamos que a maioria dos 17 carcinomas escamosos basalóides de nossa casuística $(88,2 \%)$ apresentava laudos anatomopatológicos de carcinoma espinocelular, pois muitos destes foram diagnosticados anteriormente a sua caracterização inicial, realizada por WAIN et al. ${ }^{131}$, em 1986 e, portanto, foram tratados como carcinomas espinocelulares convencionais.

Ainda como objetivo deste estudo, analisamos comparativamente os carcinomas escamosos basalóides e os carcinomas espinocelulares pouco diferenciados localizados primariamente na mucosa bucal, quanto a evolução clínica e a expressão dos biomarcadores tumorais de proliferação celular e apoptose. O carcinoma escamoso basalóide tem sido caracterizado como uma patologia agressiva ${ }^{1,2,3,7,14,18,22,34,51,52,45,56,58,79,92,95,131,133}$, muitas vezes, com prognóstico comparativamente pior do que carcinoma espinocelular convencional $^{24,26,79,134}$.

Nossos resultados relativos à análise das características demográficas e clínicas dos pacientes portadores do carcinoma escamoso basalóide localizados na língua, no soalho bucal, na área retromolar e na gengiva inferior revelaram um perfil similar ao descrito para esta neoplasia na boca e em outras regiões de cabeça e pescoço ${ }^{14,34,134}$. Observou-se o 
acometimento predominante de pacientes do gênero masculino $(88,2 \%)$, com idade média de 59,5 anos e tabagistas (85,7\%). Um perfil clínico bastante semelhante entre os pacientes com carcinoma espinocelular e escamoso basalóide quanto ao gênero, idade, uso de tabaco e álcool (Tabela 3) foi verificado em nosso estudo, corroborando com relatos anteriores ${ }^{7,13,26,34,74,92,100}$.

O local mais acometido pelo carcinoma escamoso basalóide nesta amostra foi o soalho bucal, em concordância com os relatos da literatura pertinentes a esta neoplasia na mucosa bucal $^{3,7,22,26,52,92}$. O seu aspecto clínico também evidenciou semelhança aos demais carcinomas escamosos basalóides descritos, caracterizando-se por um tumor úlceroinfiltrativo (Tabela 4).

Comparativamente ao carcinoma escamoso basalóide, quanto à localização, o carcinoma espinocelular pouco diferenciado, ocorreu com maior freqüência na área retromolar e na gengiva inferior (Tabela 4).

Verificamos que os pacientes com carcinoma escamoso basalóide na boca apresentaram no momento do diagnóstico estadiamento clínico avançado, característica esta também detectada em outros estudos ${ }^{13,34,92,134}$.

Quanto ao tratamento adotado, ressaltamos mais uma vez que os pacientes de ambos grupos (CEB e CEC) foram tratados como portadores de carcinoma espinocelular com estadiamento clínico avançado. Portanto, os pacientes foram submetidos à cirurgia para ressecção do tumor primário acompanhada do esvaziamento cervical ipsilateral ou bilateral. Ainda, em relação ao tratamento destes pacientes com carcinoma escamoso basalóide e espinocelular pouco diferenciado, nesta casuística, a cirurgia foi quase sempre complementada pela radioterapia pós-operatória nos dois grupos de pacientes analisados 
(Tabela 5). O emprego da quimioterapia adjuvante, recomendado por alguns autores $^{13,26,31,34,74,134}$ para os pacientes com CEB, foi observado nesta amostra em um pequeno número de pacientes com CEB e com CEC (Tabela 5).

A evolução clínica dos carcinomas escamosos basalóides em nosso estudo apresentou uma frequiência maior de recidiva local e cervical se comparado aos estudos de FERLITO et al. $^{34}$ e BANKS et al. ${ }^{13}$ (Tabela 5).

A ocorrência de um segundo tumor primário em pacientes com carcinoma escamoso basalóide tem sido comumente relatada ${ }^{13,34,75,105}$. Neste estudo apenas três pacientes com CEB $(17,6 \%)$ apresentaram segundo tumor primário, freqüência esta superior a detectada por BANKS et al. ${ }^{13}(5,0 \%)$ e próxima àquela identificada por FERLITO et al. ${ }^{34}(20 \%)$ em pacientes com carcinomas escamosos basalóides primários na região de cabeça e pescoço.

Clinicamente, as características gerais e a evolução dos pacientes com carcinoma espinocelular pouco diferenciado foram similares às observadas nos pacientes com carcinoma escamoso basalóide e revelaram um perfil já bem estabelecido para esta neoplasia maligna $^{13,74}$.

Ressaltamos, porém que embora sem diferença estatística, a recidiva local foi mais freqüente nos pacientes com carcinoma espinocelular pouco diferenciado (Tabela 5) e as metástases regional e a distância acometeram um maior número de pacientes com carcinoma escamoso basalóide, corroborando com alguns autores que também analisaram comparativamente os dois grupos de carcinomas espinocelulares ${ }^{26,74,134}$. O pulmão foi o sítio anatômico mais comumente acometido pelas metástases dos carcinomas escamosos basalóides e espinocelulares pouco diferenciados. 
Microscopicamente, os carcinomas escamosos basalóides aqui descritos preencheram os critérios morfológicos de classificação desta entidade patológica (Tabela 6). O componente celular basalóide foi predominante na maioria dos carcinomas analisados deste grupo, perfazendo aproximadamente $90 \%$ das células tumorais. A continuidade do CEB com a mucosa bucal, característica esta freqüentemente ressaltada nos diferentes trabalhos $^{7,9,22,24,43,50,80,92,132}$, foi verificada em 52,9\% dos fragmentos tumorais analisados (Tabela 6 e Figura 4A). Esta mucosa bucal apresentava variados graus de displasia epitelial, caracterizados como carcinoma in situ e também como carcinoma espinocelular convencional invasivo.

O carcinoma escamoso basalóide apresenta comumente um padrão de crescimento tumoral em ilhotas e cordões de diversos tamanhos, sendo a configuração sólida ou lobular a mais comumente verificada nestes tumores tanto em boca ${ }^{24,50,51}$, como outros locais da cabeça e pescoço ${ }^{13,14,57,74,134}$ e em outros órgãos como no esôfago ${ }^{1,23,100}$. Nesta amostra, esta configuração sólida/lobular foi observada em $47,1 \%$ dos carcinomas escamosos basalóides (Figuras 1A, 1B e 4A). O padrão morfológico trabecular, também observado em vários sítios anatômicos acometidos pelo carcinoma escamoso basalóide ${ }^{13,26,74,92,100,132,133,134}$ esteve presente em 29,4\% desta amostra, apresentando-se associado com o padrão sólido/lobular, em 23,5\% destes tumores (Tabela 6). Outros padrões morfológicos como o tubular e o cribiforme não foram identificados em nossa casuística, sendo relatados em carcinomas escamosos basalóides na região de cabeça e pescoço por ABIKO et al. ${ }^{3}$, ARAÚJO et al. ${ }^{9}$, BANKS et al. ${ }^{13}$, COLETTA et al. ${ }^{24}$, HELLQUIST et al. ${ }^{43}$, LARNER et al. ${ }^{68}$, WIENEKE; THOMPSON, WENING $^{1,33}$ e por SARBIA et al. ${ }^{100}$ e CHO et al. ${ }^{23}$ em esôfago. 
Os espaços císticos intratumorais foram visualizados em $88,2 \%$ dos carcinomas escamosos basalóides, freqüência esta semelhante à de outros estudos $1,3,7,9,13,23,24,26,34,68,74,100,105,123,131,133,134$. No entanto, apenas $17,6 \%$ dos CEBs apresentaram espaços císticos preenchidos por conteúdo PAS positivo. Em 23,5\% dos CEBs as células basalóides organizavam-se na forma de ductos, contendo pequenos lumes, no interior dos quais, não se detectou material PAS positivo (Figura 4B). Pequenos focos eosinofílicos hialinos e positivos ao PAS foram identificados entre as células basalóides apresentando ora distribuição aleatória sem associação com alguma estrutura morfológica específica ora circundando as células basalóides (Tabela 6 e Figuras 5A, 5B, 6A, 6B e 7A, 7B). Estes focos eosinofílicos PAS positivo usualmente encontrados em CEBs e ausentes em $\mathrm{CECs}^{28,45}$ foram descritos por vários autores ${ }^{\mathrm{a} 7,12,14,26,34,74,123,124,133}$ sugerindo se tratar, de depósitos mucóides ou muco-hialinos. Esta substância eosinofílica hialina apresentou-se semelhante à membrana basal, na avaliação ultraestrutural realizada por TAKUBO et al. ${ }^{120}$. Posteriormente, HEWAN-LOWE; DARDICK ${ }^{45}$, em 1995 e COTRIM-ZÚÑIIGA ${ }^{28}$, em 2001, identificaram nestes conteúdos hialinos, positividade para laminina, confirmando a similaridade com a membrana basal, bem como a origem epitelial das células basalóides tumorais.

Em concordância com as principais características dos carcinomas escamosos basalóides descritos na literatura ${ }^{1,3,7,13,23,24,34,79,80,92,131,133}$, verificamos em nosso estudo que a maioria das ilhotas tumorais apresentou disposição em paliçada das células periféricas com presença de necrose central por coagulação (comedonecrose) (Figuras 1A, 1B e 2A, 2B). Juntamente ao arranjo em paliçada das células tumorais, verificamos, freqüentemente a disjunção entre o epitélio tumoral e o tecido conjuntivo adjacente (Figuras 1A, e 5A, 5B). 
Notamos também, que este tecido conjuntivo adjacente apresentava aspecto hialino e positividade ao PAS (Tabela 6 e Figura 5A, 5B).

A associação das células basalóides ao componente escamoso apresentou-se de forma intercalada com áreas de queratinização, incluindo presença de pérolas córneas, ora observadas em continuidade ora no interior das ilhotas e lóbulos de células basalóides (Tabela 6 e Figura 3A, 3B). O carcinoma espinocelular esteve presente também adjacente aos lóbulos tumorais basalóides, configurando uma transição abrupta entre estes dois componentes. Esta associação dos componentes basalóide e escamoso, ora intercalada ora de forma abrupta, usualmente tem sido descrita nos carcinomas escamosos basalóides descritos em variados sítios anatômicos $1,3,7,13,14,23,24,26,34,57,74,92,100,123,131,133$.

O perfil biológico mais agressivo do carcinoma escamoso basalóide quando comparado com o carcinoma espinocelular de boca, segundo COPPOLA et al. ${ }^{26}$, pode estar correlacionado com a presença, ou ainda, com o maior percentual do componente basalóide. A análise das características biológicas das células basalóides realizada por ABIKO et al. ${ }^{2,3}$, em 1997 e em 1998, sugeriram uma atividade altamente proliferativa destas células, conferindo a elas um alto poder de invasão. Esta alta e rápida capacidade proliferativa das células basalóides foi delineada também por BABÓ et al. ${ }^{10}$, em 1998 e BABÓ; BOSCI; $\mathrm{JENEY}^{11}$,em 1999, ressaltando ainda outras características tumorais, como a produção de colagenase tipo IV pelas células escamosas, reforçando sua capacidade de infiltração tumoral no CEB. Os autores ${ }^{2,3,10,11}$ concluíram que a agressividade do carcinoma escamoso basalóide associa-se a sua heterogeneidade celular, expressada pelos diferentes fenótipos e não necessariamente, ao percentual de cada componente celular neste tumor. 
Outras características do carcinoma escamoso basalóide têm sido relacionadas com sua alta capacidade de invasão perineural, vascular, muscular e óssea ${ }^{1,3,22,26,132,133}$, e com a freqüente ocorrência de metástase regional e a distância. No entanto, neste estudo, embora nos carcinomas escamosos basalóides a ocorrência de embolização angiolinfática tenha sido maior $(p=0,025)$ quando comparado ao carcinoma espinocelular pouco diferenciado, isto não refletiu em uma diferença quanto a ocorrência de metástases regional e a distância. Além disso, observamos também que o padrão de invasão tumoral compressivo foi o mais comumente encontrado nos carcinomas escamosos basalóides (Tabela 8 e Figuras 1A, 1B e 4A). Nos carcinomas espinocelulares pouco diferenciados padrões diferentes de invasão como cordões grossos, cordões finos e células isoladas foram identificados sugerindo, microscopicamente, uma maior habilidade para infiltração de tecidos e estruturas vizinhas (Figuras 8A, 8B e 9A, B). Curiosamente, a invasão perineural foi maior nos carcinomas espinocelulares pouco diferenciados $(p=0,012)$, delineando um padrão de invasão tumoral local mais infiltrativo (Tabela 8 e Figura 11A, 11B) se comparado com o carcinoma escamoso basalóide. Os demais parâmetros como infiltração muscular (Figura 10A, 10B) e óssea apresentaram freqüências semelhantes entre os dois grupos tumorais CEB e CEC (Tabela 8).

A avaliação conjunta dos parâmetros morfológicos e da expressão das proteínas relacionadas ao comportamento biológico das células tumorais, como de sua atividade proliferativa e de seus mecanismos de morte celular programada, vem sendo cada vez mais utilizados, visando delinear o comportamento tumoral.

A marcação do antígeno nuclear de proliferação celular tem se caracterizado como um biomarcador da proliferação celular durante a oncogênese $\mathrm{e}^{39,85,86,109,111,113,115,137}$. A marcação do PCNA, na avaliação da atividade proliferativa tumoral e a expressão da proteína p53, em 
carcinomas escamosos basalóides têm demonstrado um alto índice de proliferação e um maior acúmulo da proteína p53, nestes tumores ${ }^{24,56,90}$. Contrariamente, nos carcinomas escamosos basalóides localizados na laringe os padrões de marcação do PCNA e p53 foram similares aos observados em carcinomas espinocelulares pouco diferenciados ${ }^{6}$. A maior capacidade proliferativa do carcinoma escamoso basalóide, comparativamente ao espinocelular, foi demonstrada também por SARBIA et al. ${ }^{101}$, em 1999, avaliando-se a expressão do gene $c$ myc.

A análise quantitativa dos anticorpos nucleares PCNA e p53, em nosso trabalho foi quantitativa realizada com auxílio de um sistema computadorizado de captura de imagens visando assim diminuir as diferenças interobservadores e aumentar a reprodutibilidade da avaliação imuno-histoquímica com relação a freqüência de positividade celular tumoral.

A expressão do marcador PCNA evidenciou uma maior frequiência de células tumorais imunopositivas (>60\%) no grupo CEB $(64,7 \%)$ quando comparado às células PCNA-positivas do grupo CEC (40,7\%). Entretanto estes valores relativos à imunoexpressão do PCNA não apresentaram diferença estatística significativa $(p=0,215)$, sugerindo uma atividade proliferativa semelhante entre os dois grupos tumorais (Tabela 9 e Figuras 12A, 12B e 13A, 13B).

A expressão da proteína p53, reflexo das mutações do gene supressor tumoral p53, relacionada ao comportamento agressivo tumoral ${ }^{4,24,40,70,82,108}$ foi verificada de forma equivalente nos carcinomas escamosos basalóides e nos carcinomas espinocelulares pouco diferenciados de nossa amostra (Tabela 9). As células tumorais imunopositivas (>23\%) a proteína p53 foram visualizadas em 55,5\% dos carcinomas espinocelulares pouco diferenciados, sendo identificadas em 41,2\%, nos carcinomas escamosos basalóides. No 
entanto, estas proporções de marcação a proteína p53 entre os dois grupos tumorais analisados foram próximas $(p=0,537)$ não contribuindo para uma possível distinção entre o potencial de agressividade do carcinoma escamoso basalóide e do carcinoma espinocelular pouco diferenciado na mucosa bucal (Tabela 9 e Figuras 14A, 14B e 15A, 15B).

A maioria dos trabalhos que analisou a proliferação celular nos carcinomas escamosos basalóides comparativamente aos carcinomas espinocelulares em vários sítios anatômicos, seja pela análise do índice mitótico ${ }^{26,28,100}$, marcações pelo PCNA, Ki-67/MIB-1 ou $\mathrm{AgNOR}^{3,6,24,28,66,100}$, demonstraram que o carcinoma escamoso basalóide caracteriza-se por uma maior proliferação celular, estabelecendo assim uma possível correlação com um pior prognóstico. Entretanto, em muitos destes trabalhos a comparação entre os dois tumores não foi realizada com equivalência de estadiamento e/ou localização e em outros as amostras são pequenas e pouco representativas.

O alto índice proliferativo dos carcinomas escamosos basalóides, localizados na região de cabeça e pescoço foi demonstrado por FERLITO et al. ${ }^{34}$, em 1997, a partir de marcações pelo Ki-67/MIB-1, proteína p53 e por ABE et al. ${ }^{1}$, KAWAHARA et al. ${ }^{56}$ e OWONIKOKO et al. ${ }^{90}$ a partir da imunomarcação com Ki-6 $67^{56}$ e p53 ${ }^{1,56,90}$ em carcinomas escamosos basalóides localizados no esôfago. Também COTRIN-ZÚÑ̃IGA ${ }^{28}$, COLLETA et al. ${ }^{24}$, verificaram uma maior expressão dos marcadores PCNA, p53 em carcinomas escamosos basalóides, comparativamente aos carcinomas espinocelulares de boca. Por outro lado AKYOL et al. ${ }^{6}$, em 1998, demonstraram marcações similares para PCNA e para a proteína p53 nos carcinomas escamosos basalóides e carcinomas espinocelulares de laringe. 
Embora haja uma regulação da proliferação celular via p53, no presente estudo, não detectamos associação entre a expressão da proteína p53 e do marcador de proliferação celular PCNA, em concordância com a maioria dos autores $39,85,86,111,137$.

Não apenas a atividade proliferativa do carcinoma escamoso basalóide, mas sua heterogeneidade tumoral caracterizada pelos seus distintos imunofenótipos, podem ser responsáveis pelo seu comportamento clínico ${ }^{1,9,10,11,18,25,34,58,90}$. A atividade apoptótica tem sido avaliada, a partir da expressão de proteínas da família Bcl-2, as quais possuem funções antagônicas neste processo sendo, algumas vezes, associadas a resposta às terapias utilizadas.

A expressão de proteínas pró-apoptóticas como Bax e antiapoptótica como Bcl-2 e também de demais marcadores associados à oncogênese, tem sido investigada tanto nos carcinomas espinocelulares, como nos carcinomas escamosos basalóides. WEDENBERG et al. ${ }^{132}$, SARBIA et al. ${ }^{101}$ e KAWAHARA et al. ${ }^{56}$, verificaram a marcante presença da proteína Bcl-2 nos carcinomas escamosos basalóides, embora sua relação com o prognóstico destes pacientes não tenha sido esclarecida.

Neste estudo, a caracterização dos fenômenos apoptóticos, foi realizada pela análise da expressão das proteínas pró-apoptótica Bax e antiapoptótica Bcl-X uma vez que, a resposta à recuperação antigênica dos espécimes de nossa amostra não foi satisfatória a proteína Bcl-2. A dificuldade de marcação da proteína Bcl-2 em carcinomas espinocelulares de boca comparativamente às demais proteínas apoptóticas também foi descrita em outros estudos 93,113 . A proteína Bcl-X, devido a sua alta similaridade estrutural e funcional à proteína Bcl-2, tem se tornado uma opção para a avaliação dos processos antiapoptóticos. Segundo XIE et al. ${ }^{135}$, a indução da apoptose pelas proteínas da família do gene bcl-2 e a influência destas proteínas individualmente pode variar de tumor para tumor nos carcinomas de cabeça e 
pescoço e de outras localizações, justificando a discrepância observada na literatura relativa ao prognóstico e a expressão de Bax e Bcl-2. As diferenças nas técnicas de imunomarcação e nos métodos de avaliação tumoral podem ser parcialmente responsáveis por estes resultados contraditórios.

A avaliação dos marcadores Bcl-X e Bax em nosso estudo foi realizada a partir de um sistema de escores duplo baseado na proporção e na intensidade de marcação das células tumorais $^{112}$, visando minimizar a subjetividade deste método de análise. Os carcinomas escamosos basalóides e os espinocelulares pouco diferenciados avaliados neste estudo não diferiram quanto à expressão da proteína antiapoptótica $\mathrm{Bcl}-\mathrm{X}(p=0,757)$, sendo ambos grupos tumorais caracterizados por um padrão de imunomarcação forte (Tabela10 e Figuras 18A, 18B e 19A, 19B). A intensa expressão da proteína antiapoptótica Bcl-X, reforça sua participação como um regulador negativo dos processos da apoptose nos carcinomas escamosos basalóides e espinocelulares pouco diferenciados.

A ação inibitória de Bcl-2 e de sua homologa Bcl-X na apoptose e na entrada das células no ciclo celular, como sugerido por HUANG et al. ${ }^{48}$, apresentam conseqüente valor terapêutico uma vez que, as células tumorais que expressam estas proteínas podem estar duplamente protegidas, pois além de se tornarem refratárias a apoptose, tornam-se quiescentes. Sugeriu-se então que a alta expressão da proteína Bcl-X nas células neoplásicas relaciona-se à resistência tumoral aos estímulos apoptóticos induzidos pelos agentes terapêuticos ${ }^{48,84,93}$, caracterizando-os como neoplasias biologicamente agressivas e com prognóstico desfavorável. Em nosso estudo a expressão de Bcl-X foi similar entre os grupos tumorais analisados refletindo o perfil biológico agressivo, delineado por uma possível 
supressão da atividade apoptótica tanto nos CEBs como nos CECs, neoplasias malignas consideradas altamente agressivas.

Quanto à marcação da proteína pró-apoptótica Bax, diferença estatisticamente significativa foi identificada entre os carcinomas escamosos basalóides e espinocelulares pouco diferenciados $(p=0,031)$. Os carcinomas escamosos basalóides apresentaram dois padrões distintos de marcação, apresentando a maioria dos tumores $(88,2 \%)$ um padrão de marcação forte e em um pequeno número imunomarcação negativa $(11,8 \%)$ para esta proteína (Tabela11 e Figura 16A, 16B). Os carcinomas espinocelulares pouco diferenciados exibiram também uma imunomarcação forte em $52,4 \%$ dos casos, sendo que em 28,6\% dos tumores observou-se uma imunomarcação fraca e em 19,0\% uma marcação negativa (Tabela11 e Figura 17A, 17B).

A detecção da proteína Bax associa-se com a indução da apoptose, a partir da contenção da atividade supressora de Bcl-2 ou de suas proteínas homólogas. Uma vez que a proporção entre Bcl-2 e Bax modula os mecanismos apoptóticos, a expressão destas proteínas geralmente são antagônicas. As imunomarcações das células tumorais pelas proteínas Bcl-X e Bax, simultaneamente, na região do "front" de invasão tumoral dos carcinomas escamosos basalóides sugerem que diferentes proporções destas proteínas, bem como a sua interação com outros membros da família Bcl-2, podem caracterizar diferentes imunofenótipos das populações tumorais, responsáveis pela evolução clínica e respostas terapêuticas distintas como sugerido por GALLO et al. ${ }^{37,37}$, PENA et al. ${ }^{93}$, XIE et al. ${ }^{135}$ e MESE et al. ${ }^{76}$.

Embora em nossa casuística, a expressão da proteína Bax tenha sido maior nos carcinomas escamosos basalóides, os pacientes de ambos grupos apresentaram uma resposta similar as terapias empregadas, a qual foi equivalente, entre os grupos de estudo. Uma vez 
que a sensibilidade das células àapoptose é modulada pela proporção entre as proteínas anti e pró-apoptóticas, pesquisamos a proporção entre Bcl-X e Bax nos CEBs e CECs. Não foi detectada distinção entre os dois grupos tumorais estudados, quanto à expressão proporcional de positividade das proteínas Bcl-X/Bax, reforçando a similaridade do fenótipo maligno entre as duas neoplasias estudadas.

A falta de associação entre a expressão da proteína p53 e das proteínas Bax e Bcl-X, neste estudo, sugerem que estas proteínas estariam atuando nos processos da apoptose de forma independente, como previamente sugerido por PENA et al. ${ }^{93}, \mathrm{SCHOELCH}$ et al. ${ }^{102} \mathrm{e}$ RAVI et al. ${ }^{96}$, contrariando as evidências relatadas por MIYASHITA et al. ${ }^{77}$ e MIYASHITA; $\mathrm{REED}^{78}$ quanto à regência da proteína p53 nos processos apoptóticos efetuados pelas proteínas do gene bcl-2.

As diferenças pesquisadas entre os dois grupos tumorais (CEB e CEC) quanto ao comportamento biológico, por meio de biomarcadores imuno-histoquímicos, somente nos revelaram resultados estatisticamente significativos para a expressão da proteína Bax. Além disso, o valor prognóstico de todos os marcadores utilizados neste estudo e principalmente da variante morfológica tumoral não apresentou impacto na sobrevida dos pacientes com carcinomas espinocelulares de boca.

Embora a utilização dos marcadores imuno-histoquímicos relacionados à proliferação celular e apoptose apresenta-se para muitos autores limitada ao delineamento do comportamento biológico dos tumores ${ }^{23,39,59,60,81,87,89,113,116,138}$, para outros ${ }^{35,47,93,125,136}$ o valor prognóstico destes marcadores tem sido investigado como complemento dos parâmetros clínicos e morfológicos tumorais. 
O PCNA tem sido considerado um marcador da resposta tumoral às terapias anticancer $^{126,109}$ e um fator prognóstico para carcinomas espinocelulares de boca ${ }^{113,118}$. No presente estudo, a quantificação do PCNA nos CEBs e CECs, não influenciou as taxas de sobrevida global, sobrevida específica e sobrevida livre de doença dos pacientes com carcinoma escamoso basalóide e espinocelular pouco diferenciado. Esses resultados são congruentes com a maioria ${ }^{39,71,81,85,86,111}$ dos estudos que não comprovaram o valor prognóstico deste marcador em carcinomas espinocelulares de boca.

Em relação ao valor prognóstico da proteína p53, a ambigüidade de resultados, detectados na literatura, pode estar associada à variabilidade da amostra, ou à discordância entre a expressão desta proteína e a ocorrência de mutações, uma vez que a estabilização da proteína p53 pode ser associada com outras proteínas reguladoras do ciclo celular $^{4,37,49,65,70,91,121}$. O valor prognóstico da proteína p53 nos carcinomas espinocelulares da cabeça e pescoço é controvertido, no entanto, muitos autores ressaltam que esta proteína reflete as propriedades biológicas do tumor durante a carcinogênese $23,40,41,46,47,53,55,59,61,71,85,86,87,89,102,103,116,110,111,128,135,138$.

A expressão da proteína p53 em nosso estudo não contribuiu para a possível distinção entre comportamento biológico do carcinoma escamoso basalóide e do carcinoma espinocelular pouco diferenciado e também não influenciou o prognóstico dos pacientes nas análises de sobrevida global, específica e livre de doença.

A expressão dos anticorpos PCNA, p53, Bcl-X e Bax foi sempre avaliada, na região do "front" de invasão tumoral, em virtude de ser esta uma região que contém informações com maior valor prognóstico quando comparado às demais áreas do tumor pois reflete com fidelidade os principais eventos biológicos da interação tumor/hospedeiro ${ }^{12,19,20,119}$. 
Observamos que, embora a imunomarcação à proteína Bax tenha sido significativa no teste de freqüências entre os pacientes com carcinoma escamoso basalóide e carcinoma espinocelular pouco diferenciado, as probabilidades de sobrevida global, especifica e livre de doença não apresentaram diferenças estatisticamente significativas para ambos grupos tumorais analisados. Contrariamente a esses resultados, XIE et al. ${ }^{135}$ demonstraram que a proteína Bax influenciou os CECs localizados na língua. Estes autores correlacionaram ainda os altos escores desta proteína a uma resposta satisfatória a radioterapia em pacientes com carcinoma espinocelular na língua, bem como a um prognóstico favorável, caracterizado por uma maior probabilidade de sobrevida livre de doença $(p=0,0012)^{135}$. Verificaram também ${ }^{135}$ que a proporção entre Bcl-2 e Bax, via dimerização foi um forte fator para o controle da apoptose, sendo a correlação entre estas duas proteínas uma variável de alto impacto na sobrevida dos pacientes. Os resultados acima ${ }^{135}$ são conflitantes com outras análises do valor prognóstico e da expressão da proteína Bax na resposta tumoral a radioterapia ou quimioterapia em pacientes com carcinomas espinocelulares de boca ${ }^{27,47,96}$.

A forte expressão da proteína antiapoptótica Bcl-X no presente estudo, além de inconsistente para a distinção entre os dois grupos tumorais estudados, também não influenciou o prognóstico dos pacientes com carcinomas escamoso basalóide e espinocelular pouco diferenciado na mucosa bucal, em concordância com o estudo de PENA et al. ${ }^{93}$ em carcinomas espinocelulares da região de cabeça e pescoço.

Verificamos que nossos resultados quanto ao valor prognóstico dos marcadores de proliferação celular e de apoptose, principalmente nos carcinomas escamosos basalóides são congruentes com as análises deste tumor em esôfago ${ }^{23,60,66,100}$, uma vez que na região de cabeça e pescoço a expressão destes marcadores imuno-histoquímicos foram realizados em 
casuísticas pequenas impossibilitando a determinação de seu valor prognóstico. Assim, trabalhos como o de SARBIA et al. ${ }^{100}$, em 1997, demonstraram que embora o CEB tenha apresentado um maior índice de proliferação comparativamente ao CEC, não houve diferença significativa entre as probabilidades de sobrevida acumulada em dois e cinco anos para estes dois grupos de pacientes. Também LAM et al. ${ }^{66}$, em 2001, em um estudo retrospectivo de dez anos, de 30 carcinomas escamosos basalóides identificados dentre 756 espécimes de carcinomas de esôfago, demonstraram que embora a média das células positivas para o anticorpo MIB-1 no carcinoma escamoso basalóide tenha sido maior que no carcinoma espinocelular, as probabilidades de sobrevida acumuladas em cinco anos não diferiram entre os pacientes acometidos por estas variantes do carcinoma.

A influência da morfologia tumoral no prognóstico do CEB e do CEC foi o principal alvo de investigação no nosso estudo. Os resultados demonstraram um prognóstico similar entre os pacientes com carcinoma escamoso basalóide e com carcinoma espinocelular pouco diferenciado, delineados pelas análises de sobrevida global, sobrevida específica e sobrevida livre de doença. Nenhuma diferença estatística entre estas taxas de sobrevida foi verificada nos pacientes dos dois grupos tumorais, independentemente das marcações imunohistoquímicas. Estes resultados corroboram com os encontrados por SARBIA et al. ${ }^{100}$, KOIDE et al. ${ }^{60}$ e LAM et al. ${ }^{66}$ que verificaram que a variante histológica não constituiu fator prognóstico em análises comparativas entre o carcinoma escamoso basalóide e o carcinoma espinocelular.

Com relação ao comportamento clínico, nossos resultados não suportam os dados pertinentes ao comportamento mais agressivo do carcinoma escamoso basalóide comparativamente ao carcinoma espinocelular. Na mucosa bucal, este comportamento mais 
agressivo do carcinoma escamoso basalóide foi delineado em estudos que apenas descreveram a evolução clínica ou o perfil imuno-histoquímico desta neoplasia sem uma análise das principais variáveis que influenciam as taxas de sobrevida e conseqüentemente o prognóstico destes pacientes ${ }^{2,3,24,26}$. Além disso, casuísticas pequenas com avaliação de apenas dois pacientes com carcinoma escamoso basalóide em boca como realizado por ABIKO et al. ${ }^{3}$ e COLETTA et al. ${ }^{24}$ não permitem um delineamento consistente do potencial de agressividade tumoral, bem como da evolução clínica e do prognóstico dos pacientes acometidos por esta neoplasia maligna.

Como discutido no início deste capítulo, as características clínicas dos pacientes com carcinoma escamoso basalóide e carcinoma espinocelular pouco diferenciado no presente estudo, apresentaram no momento diagnóstico estadiamento clínico avançado, associado com uma alta freqüência de comprometimento dos linfonodos regionais. A variável de estudo N, foi fator independente indicativo de prognóstico desfavorável em ambos grupos de estudo. O risco relativo de morte para os pacientes com metástase linfonodal $(\mathrm{N}+)$ no momento do diagnóstico para ambos grupos tumorais analisados foi três vezes maior comparativamente aos pacientes sem comprometimento linfonodal (N0) $(p=0,051)$.

As análises clínicas e imuno-histoquímicas realizadas nos permitem concluir que os pacientes com carcinoma escamoso basalóide apresentam um prognóstico similar ao dos pacientes acometidos pelo carcinoma espinocelular pouco diferenciado com localização e estadiamento clínico equivalentes na mucosa bucal, podendo ser submetidos aos mesmos protocolos terapêuticos. Entretanto, outros estudos são necessários para a confirmação destes resultados incluindo grupos de pacientes com diferentes estádios clínicos, bem como, estendendo-se estas análises comparativas para outros sítios anatômicos. 
7 CONCLUSÃO 


\section{CONCLUSÃO}

Analisando-se as características demográficas, clínicas e microscópicas de 17 pacientes com carcinoma escamoso basalóide e 27 pacientes com carcinoma espinocelular pouco diferenciado, localizados na língua, soalho bucal, gengiva inferior e área retromolar, verificamos que:

os pacientes acometidos pelo carcinoma escamoso basalóide eram predominantemente do gênero masculino, raça branca, com idade média de 59,5 anos, tabagistas e etilistas, apresentando no momento do diagnóstico estadiamento clínico avançado;

o soalho bucal foi o local mais comumente acometido pelo CEB sendo as lesões, freqüentemente, ulceroinfiltrativas;

a ressecção ampla do tumor primário, o esvaziamento cervical ipsilateral e a radioterapia pós-operatória foram realizados na maioria dos pacientes com CEB;

as recidivas local e regional, bem como, a metástase a distância e a ocorrência do segundo tumor primário não foram detectadas na maior parte dos pacientes com CEB após o tratamento;

verificou-se diferença estatística quanto a embolização angiolinfática $(p=0,025)$ e infiltração perineural $(p=0,012)$ entre os grupos CEB e CEC;

morfologicamente, a maioria dos carcinomas escamosos basalóides apresentou configuração tumoral sólida/lobular, padrão de invasão tumoral compressivo, disposição 
em paliçada das células periféricas das ilhotas tumorais, espaços císticos, necrose central por coagulação (comedonecrose), hialinização intra e peritumoral, disjunção epitélio tumoral/conjuntivo e associação com o componente escamoso;

os carcinomas escamosos basalóides apresentaram um alto índice proliferativo, detectado pela quantificação das células tumorais imunopositivas ao anticorpo PCNA (64,7\% da amostra com $>60 \%$ de positividade);

a expressão a proteína p53 foi freqüentemente, observada no carcinoma escamoso basalóide, perfazendo porém 47,2\% da amostra com positividade>23\%;

os escores de imunomarcação revelaram uma forte expressão da proteína Bax e da proteína Bcl-X nos carcinomas escamosos basalóides;

não foram detectadas diferenças estatísticas entre os pacientes com carcinoma escamoso basalóide e espinocelular pouco diferenciado no que se refere às características demográficas, clínicas, tratamento, evolução e imunomarcação dos anticorpos PCNA, p53, Bcl-X e a proporção Bcl-X/Bax;

a forte expressão da proteína Bax foi maior nos carcinomas escamosos basalóides quando comparada ao carcinoma espinocelular pouco diferenciado $(p=0,031)$;

a expressão dos marcadores imuno-histoquímicos PCNA, proteína p53, proteínas Bax e Bcl-X não foi fator prognóstico para os pacientes com carcinoma escamoso basalóide e carcinoma espinocelular pouco diferenciado na mucosa bucal;

47,0\% dos pacientes com carcinoma escamoso basalóide morreram em decorrência do tumor primário, as probabilidades de sobrevida global acumuladas em 5 e 10 anos foram 
respectivamente, $46,7 \%$ e $20,8 \%$, de sobrevida específica $50,2 \%$ e $50,2 \%$, de sobrevida livre de doença $39,6 \%$ e 39,6\%;

o prognóstico dos pacientes com carcinoma escamoso basalóide e carcinoma espinocelular pouco diferenciado localizados na mucosa bucal foi similar, uma vez que, as probabilidades de sobrevida global, específica e livre de doença, acumuladas em 5 e 10 anos não apresentaram diferenças estatísticas;

o estadiamento clínico $\mathrm{N}$ constituiu um fator prognóstico independente para os pacientes com carcinoma escamoso basalóide e carcinoma espinocelular pouco diferenciado na mucosa bucal.

Estes resultados permitiram concluir que o carcinoma escamoso basalóide e o carcinoma espinocelular pouco diferenciado com localização e estadiamento clínico equivalentes na boca apresentam um comportamento biológico e clínico similares. Assim sendo, os pacientes acometidos por estes tumores podem ser submetidos aos mesmos protocolos terapêuticos. 
ANEXOS 
ANEXO 1 - Ficha utilizada para a coleta dos dados clínicos e microscópicos relativos aos pacientes com carcinoma escamoso basalóide e com carcinoma espinocelular pouco diferenciado de boca

\section{Registro da coleta de dados}

\section{Faculdade de Odontologia de Bauru / USP}

Departamento de Estomatologia - Área de Patologia

Fundação Antônio Prudente / Hospital do Câncer

Departamento de Anatomia Patológica

Departamento de Cirurgia de Cabeça e Pescoço e Otorrinolaringologia

“Carcinoma Escamoso Basalóide na Mucosa Bucal: Análise dos Índices Proliferativo e Apoptótico”

Fernanda Costa Grizzo de Sampaio Góes; Dra. Denise Tostes Oliveira;

Dr. Gilles Landman; Dr. Luiz Paulo Kowalski

\section{Identificação e dados demográficos:}

1. Número no estudo:

2. RGH:

3. Idade:

anos

4. Sexo: $\square$ 1-masculino $\square$ 2-feminino

5. Raça: $\square$ 1-branca $\square$ 2-não branca

II. História clínica:

6. Tempo de história: meses (999 se desconhecido)

7. Tabagismo: $\square$ 0-não $\square$ 1-sim $\square$ 9-desc.

8. Etilismo: $\square$ 0-não $\square$ 1- sim $\square$ 9-desc.

\section{Locorregional:}

9. Local de tumor: $\square$ 1- língua $\square$ 2- soalho $\square$ 3-gengiva inferior $\square$ 4-retromolar

10. Extensão do tumor: $\square$ 0-não $\square$ 1-uma área $\square$ 2-duas áreas $\square$ 3-três áreas $\square$ 4-quatro áreas

11. Tipo de lesão: $\square$ 1-ulcerovegetante $\square$ 2-ulceroinfiltrativa

12. Estádio T (atualizar UICC 87): $\square$ 1-T1 $\square$ 2-T2 $\square$ 3-T3 $\square$ 4-T4

13. Estádio N (atualizar UICC 87): $\square$ 0-N0 $\square$ 1-N1 $\square$ 2-N2a $\square$ 3-N2b $\square$ 4-N2c $\square$ 5- N3

IV. Cirurgia: 
14. Data da cirurgia:

15. Cir. Tumor primário: $\square$ 1-cirurgia sem esvaz. cervical com esvaz. cervical contral. (simult.)

$\square$ 2- cirurgia com esvaz. cervical ipsilateral $\square$ 3- cirurgia

16. Data da alta hospitalar:

V. Radioterapia pós-operatória:

17. : $\square$ 0-não $\square$ 1-sim

VI. Quimioterapia pós-operatória:

18. : $\square$ 0-não $\square$ 1-sim

\section{Análise microscópica:}

19. Número do AP:

20. Anatomopatólogico do tumor primário: $\square$ 1-CEC I $\square$ 2-CEC II $\square$ 3-CEC III $\square$ 4-CBE $\square$ 5- CA indif.

21. COMPONENTE BASALÓIDE: $\square$ 0-ausente $\square$ 1-presente $\%$ observado no espécime

22. Continuidade com a mucosa bucal: $\square$ 0-ausente $\square$ 1-presente $\square$ 2-não observada mucosa bucal

23. Padrão do tumor: $\square$ 1-sólido/lobular $\square$ 2-trabecular $\square$ 3-tubular (pseudoglandular) $\square$ 4-cribiforme

24. Disposição em paliçada (ilhotas): $\square$ 0-ausente $\square$ 1-presente

25. Pontes intercelulares: $\square$ 0-ausente $\square$ 1-presente

26. Figuras de mitoses: $\square$ 0-ausente $\square$ 1-presente

27. Espaços císticos: $\square$ 0-ausente $\square$ 1-presente

28. Espaços císticos PAS positivos: $\square$ 0-ausente $\square$ 1-presente

29. Estruturas ductiformes: $\square$ 0-ausente $\square$ 1-presente

30. Estruturas ductiformes PAS positivas: $\square$ 0-ausente $\square$ 1-presente

31. Necrose central por coagulação: $\square$ 0-ausente $\square$ 1-presente $\%$ observado no espécime

32. Hialinização: $\square$ 0-ausente $\square$ 1-intratumoral $\square$ 2-peritumoral $\square$ 3-ambas

33. Disjunção epitélio tumoral/conjuntivo: $\square$ 0-ausente $\square$ 1-presente

34. Componente escamoso associado: $\square$ 1-intercalado $\square$ 2-adjacente

35. COMPONENTE ESCAMOSO: $\square$ 0-ausente $\square$ 1-presente

36. Continuidade com a mucosa bucal: $\square$ 0-ausente $\square$ 1-presente $\square$ 2-não observada mucosa bucal

37. Disqueratose: $\square 0$-ausente $\square$ 1-presente

38. Pérolas córneas: $\square$ 0-ausente $\square$ 1-presente

39. Pontes intercelulares: $\square$ 0-ausente $\square$ 1-presente

40. Figuras de mitoses: $\square$ 0-ausente $\square$ 1-presente

41. Hipercromatismo: $\square$ 0-discreto $\square$ 1-moderado $\square$ 2-intenso

42. Pleomorfismo: $\square 0$ discreto $\square$ 1-moderado $\square$ 2-intenso

43. Disposição em paliçada: $\square$ 0-ausente $\square$ 1-presente

44. Espaços císticos: $\square$ 0-ausente $\square$ 1-presente

45. Espaços císticos PAS positivos: $\square$ 0-ausente $\square$ 1-presente

46. Estruturas ductiformes: $\square$ 0-ausente $\square$ 1-presente

47. Estruturas ductiformes PAS positivas: $\square$ 0-ausente $\square$ 1-presente 
48. Necrose por coagulação: $\square 0$-ausente

1-presente $\%$ observado no espécime

49. Hialinização: $\square$ 0-ausente $\square$ 1-intratumoral $\square$ 2-peritumoral $\square$ 3-ambas

50. Disjunção epitélio tumoral/conjuntivo: $\square$ 0-ausente $\square$ 1-presente

51. Padrão de invasão tumoral: $\square$ 1- compressivo $\square$ 2- cordões grossos $\square$ 3-cordões finos $\square$ 4- células isoladas

52. Infiltrado inflamatório: $\square$ 0-ausente $\square$ 1-discreto $\square$ 2-moderado $\square$ 3-intenso

53. Embolização vascular: $\square$ 0-não $\square$ 1-linfática $\square$ 2-sangüínea $\square$ 3-ambas $\square$ 9-ign.

54. Infiltração perineural: $\square$ 0-não $\square$ 1-presente $\square$ 9-ignorado

55. Infiltração muscular: $\square$ 0-não $\square$ 1-presente $\square$ 9-ignorado

56. Infiltração óssea: $\square$ 0-não $\square$ 1-presente $\square$ 9-ignorado

57. Margens: $\square$ 0-livres $\square$ 1-comprometidas $\square$ 9-ignorado

58. IM PCNA:

59. IM p53:_ $\%$

60. Escore Bax:

61. Escore Bcl-X: $\%$

\section{Evolução:}

62. Recidiva local: $\square$ 0-não $\square$ 1-sim $\square$ 9-ign.

63. Recidiva cervical: $\square$ 0-não $\square$ 1-sim $\square$ 9-ign.

64. Metástase à distância: $\square$ 0-não $\square$ 1-sim $\square$ 9-ign.

65. Data da primeira recidiva: _________ ( $10 / 10 / 1910$ se não teve $)$

66. Locais de recidiva: $\square$ 0-não teve $\square$ 1-local $\square$ 2-pescoço ipsi $\square$ 3-pescoço contra $\square$ 4-pulmão $\square$ 5-osso $\square$ 6-fígado $\square$ 7-outra à distância _ـ $\square$ 8-teve recidiva, local ignorado $\square$ 9-ignorado (perdido de vista assintomático $<5$ anos)

67. Segundo tumor primário: $\square$ 0-não $\square$ 1-sim $\square$ 9-ign.

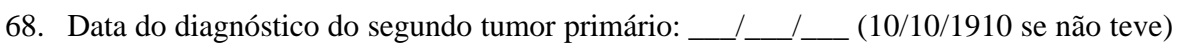

69. Local do segundo tumor primário: CID-O (9 se não teve)

70. Data da última informação objetiva de seguimento:

71. Situação na última informação de seguimento: $\square$ 1-vivo $000 \quad \square$ 2-vivo com CA $\square$ 3- Moci $\square$ 4-Moca $\square$ 5Moass__ $\square$ 6-perdido de vista (definição: para pacientes com menos de 5 anos de seguimento todos os que deixaram de retornar por um período igual ao dobro estipulado. Pacientes assintomáticos perdidos após 5 anos devem ser classificados como vivos 000 )

OBS: Para pacientes perdidos de vista: anotar nome, endereço e telefone. Entregar o prontuário aos responsáveis pela convocação de pacientes esta lista diariamente. 
ANEXO 2 - Análise da expressão do PCNA nas células tumorais do grupo CEB

\section{PLANILHA GRUPO 1 PCNA}

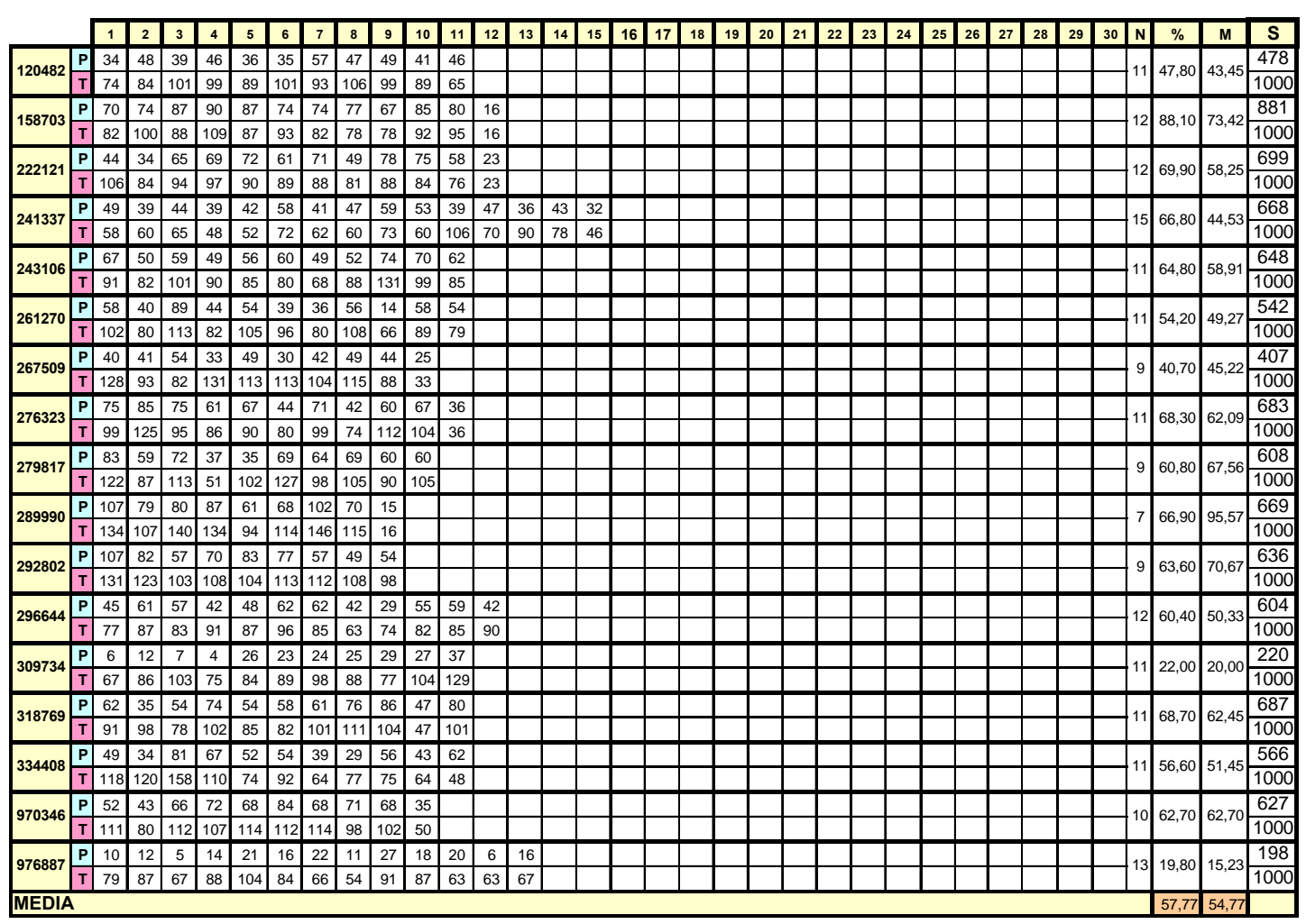

\begin{tabular}{|c|c|}
\hline & $\overline{N D A}$ \\
\hline $\mathbf{P}$ & Jnúmero de células positivas \\
\hline $\bar{T}$ & número total de células do campo (positivas+negativas) \\
\hline $\mathbf{N}$ & número de campos que foram necessários para perfazer um total de 1000 células contadas (positivas+negativas) \\
\hline$\%$ & porcentagem de células positivas em relacão a 1000 células contadas \\
\hline $\bar{M}$ & média de células positivas por campo \\
\hline $\mathbf{S}$ & somatório dos campos \\
\hline
\end{tabular}


ANEXO 3 - Análise da expressão do p53 nas células tumorais do grupo CEB

\section{PLANILHA GRUPO 1 P53}

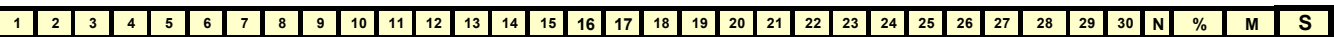

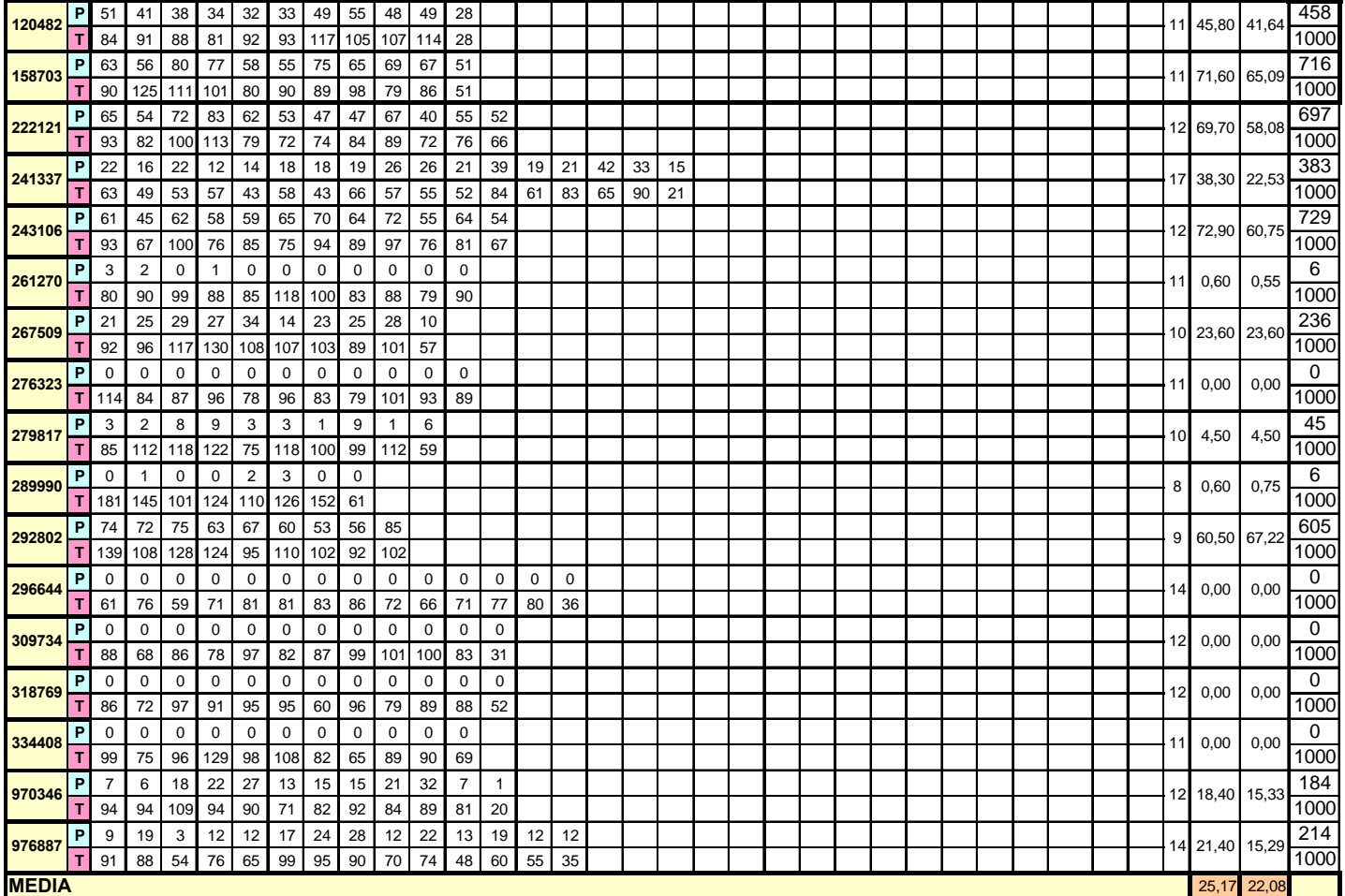

$\mathbf{P}$ número de células positivas

$\mathrm{T}$ número total de células do campo (positivas+negativas)

N número de campos que foram necessários para perfazer um total de 1000 células contadas (positivas+negativas)

$\%$ porcentagem de células positivas em relação a 1000 células contadas

M média de células positivas por campo

$\mathbf{S}$ somatório dos campos 
ANEXO 4 - Análise da expressão do PCNA nas células tumorais do grupo CEC

PLANILHA GRUPO 2 PCNA
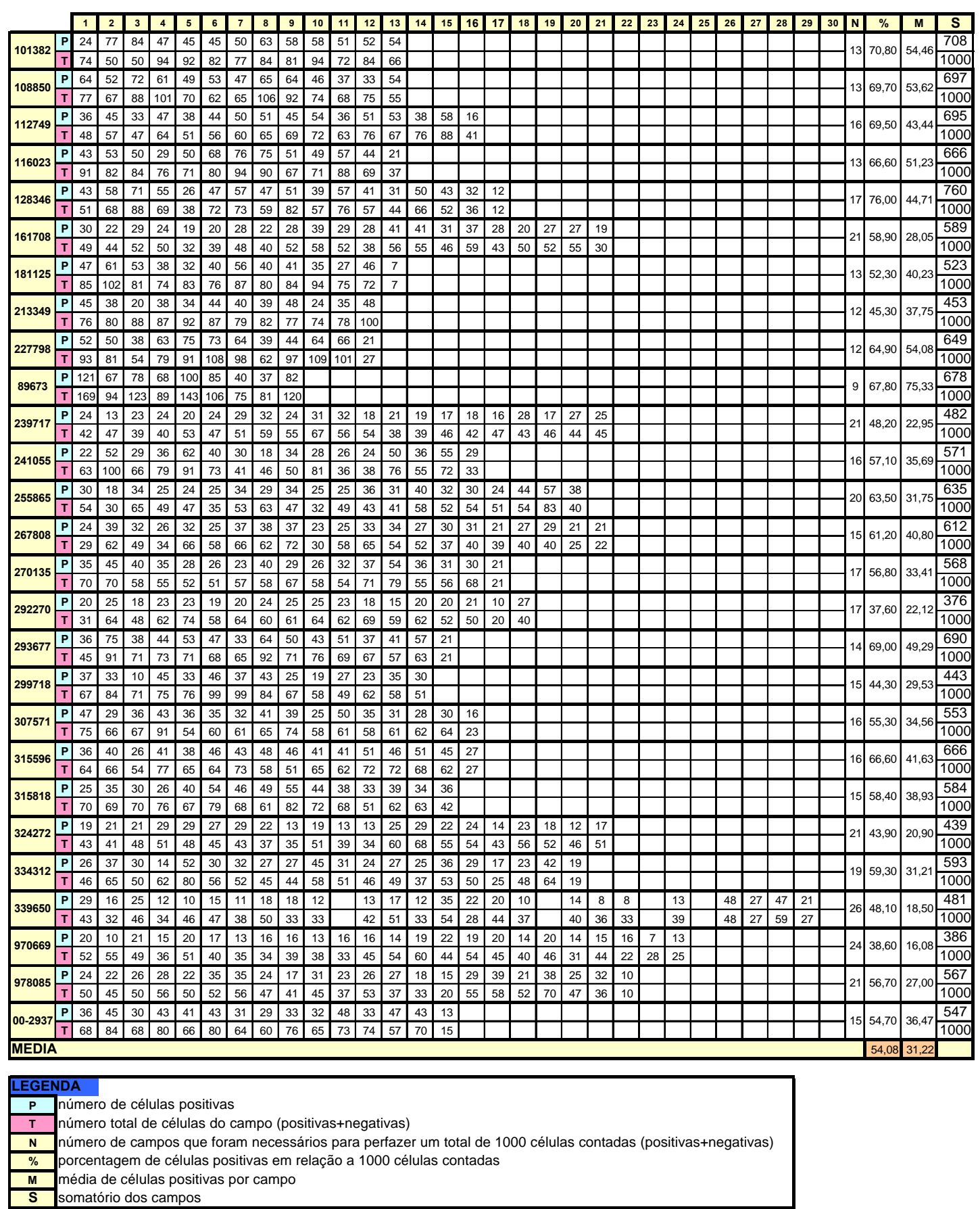
ANEXO 5 - Análise da expressão do P53 nas células tumorais do grupo CEC

PLANILHA GRUPO 2 P53

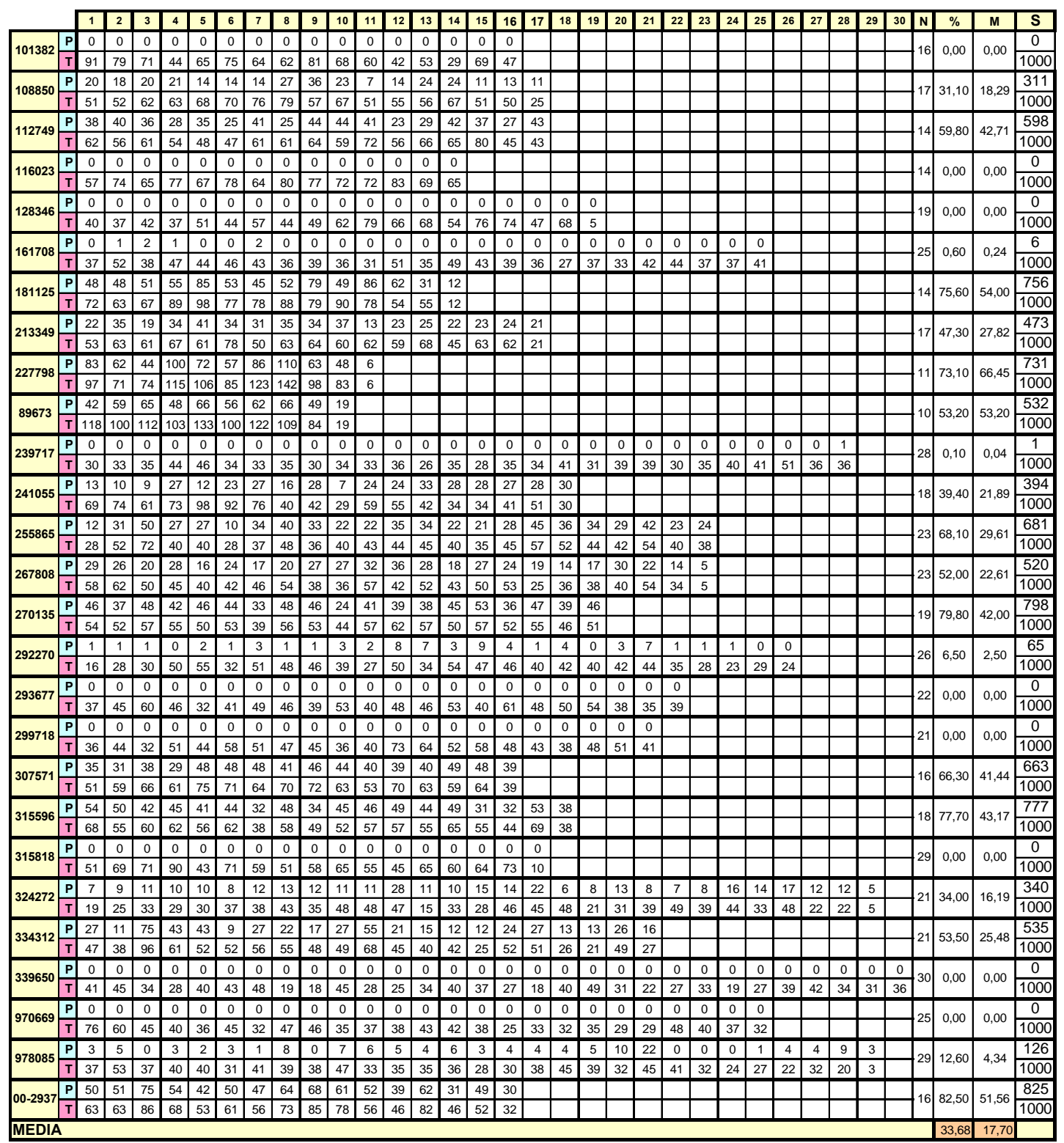
MEDIA

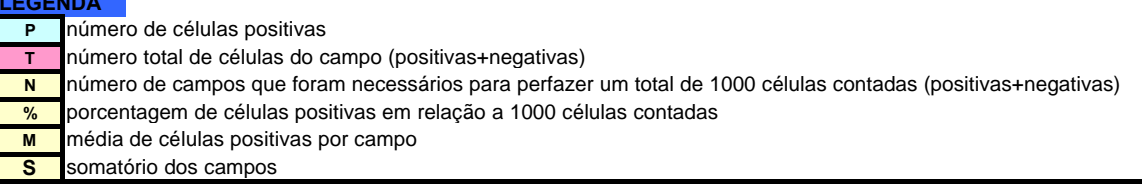


ANEXO 6- Análise da expressão do Bax nas células tumorais do grupo CEB

\section{PLANILHA GRUPO 1 - BAX}
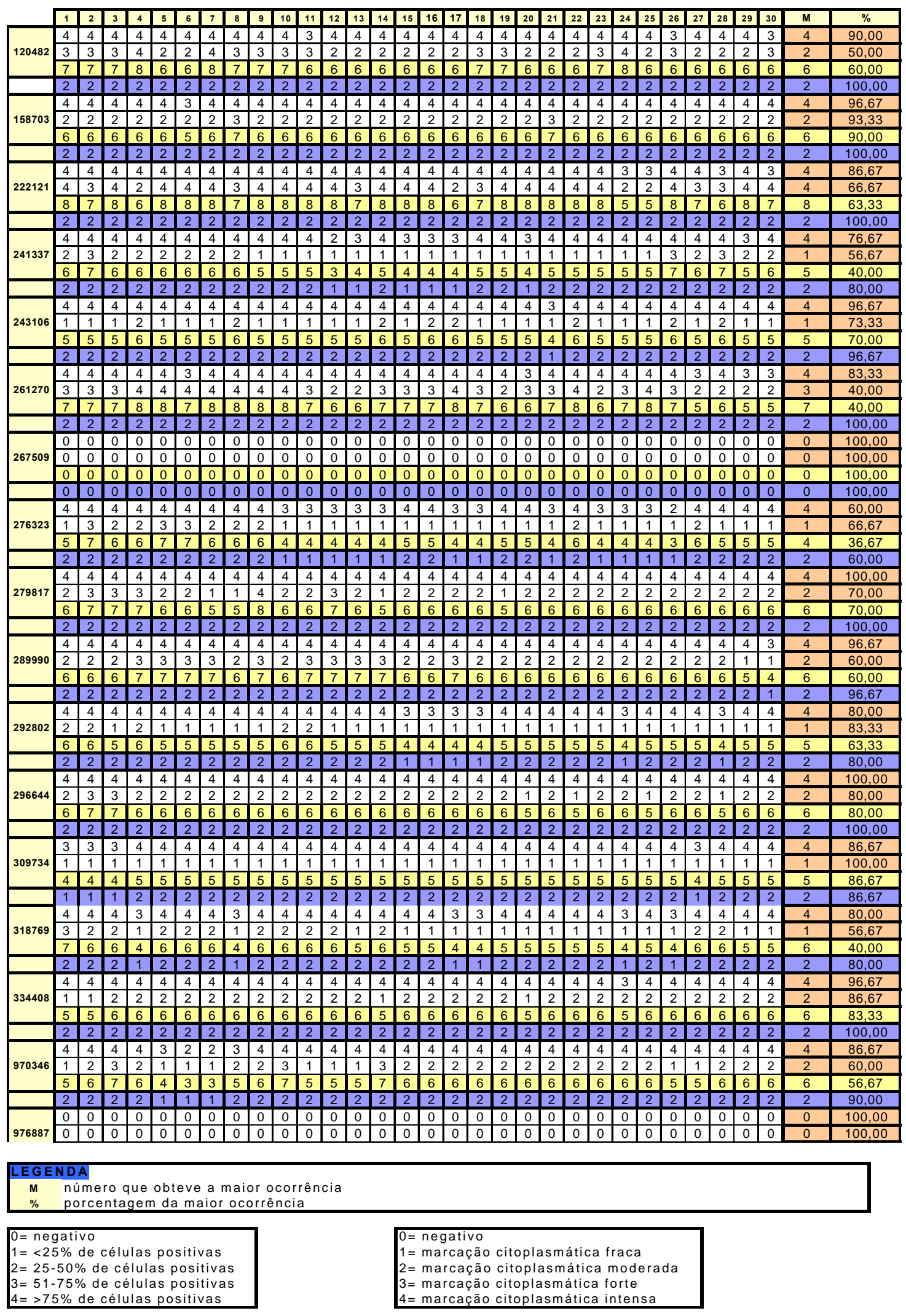
ANEXO 7 - Análise da expressão do Bax nas células tumorais do grupo CEC

PLANILHA GRUPO 2 - BAX

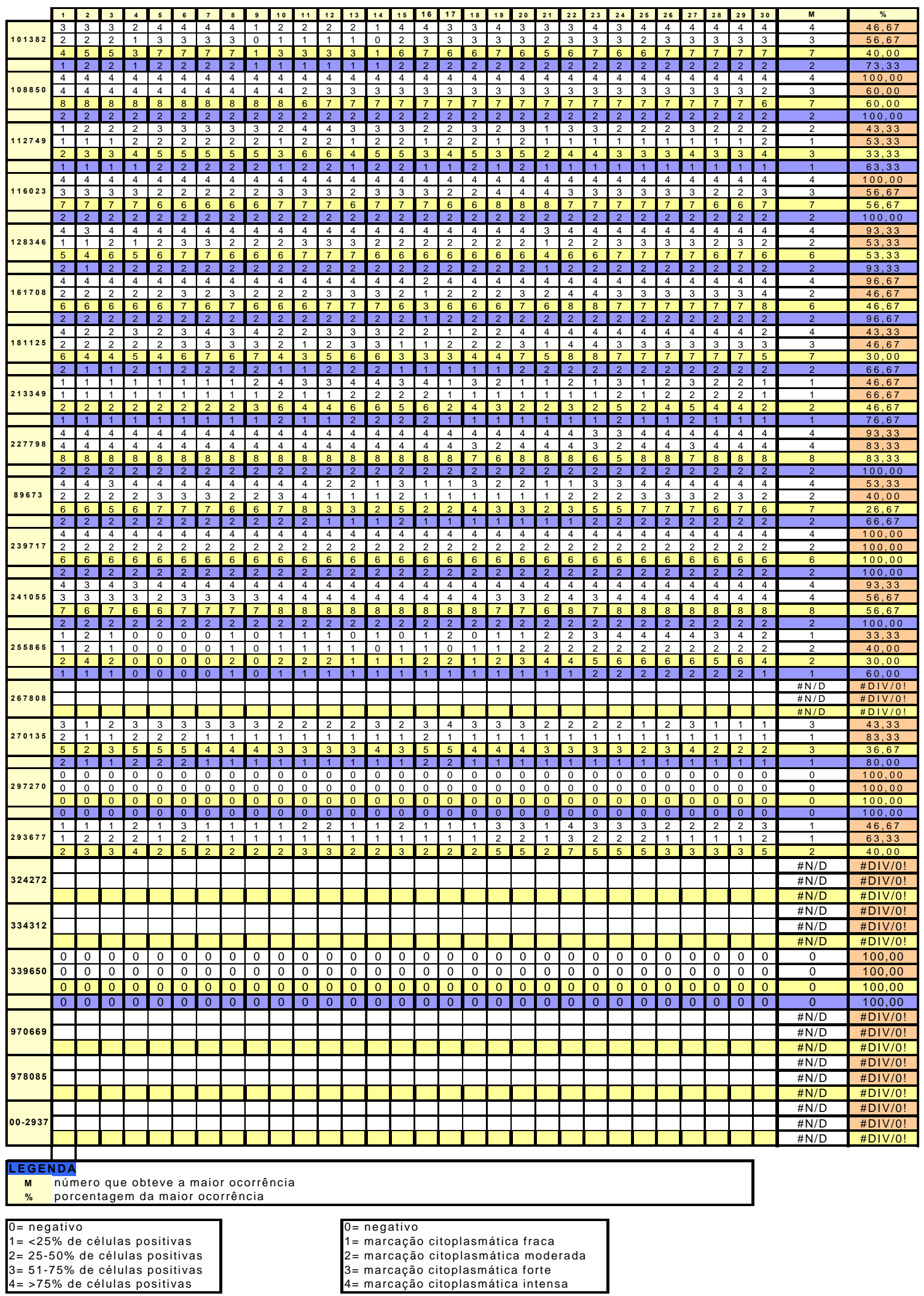


ANEXO 8 - Análise da expressão do Bcl-X nas células tumorais do grupo CEB PLANILHA GRUPO 1 - BCL-X

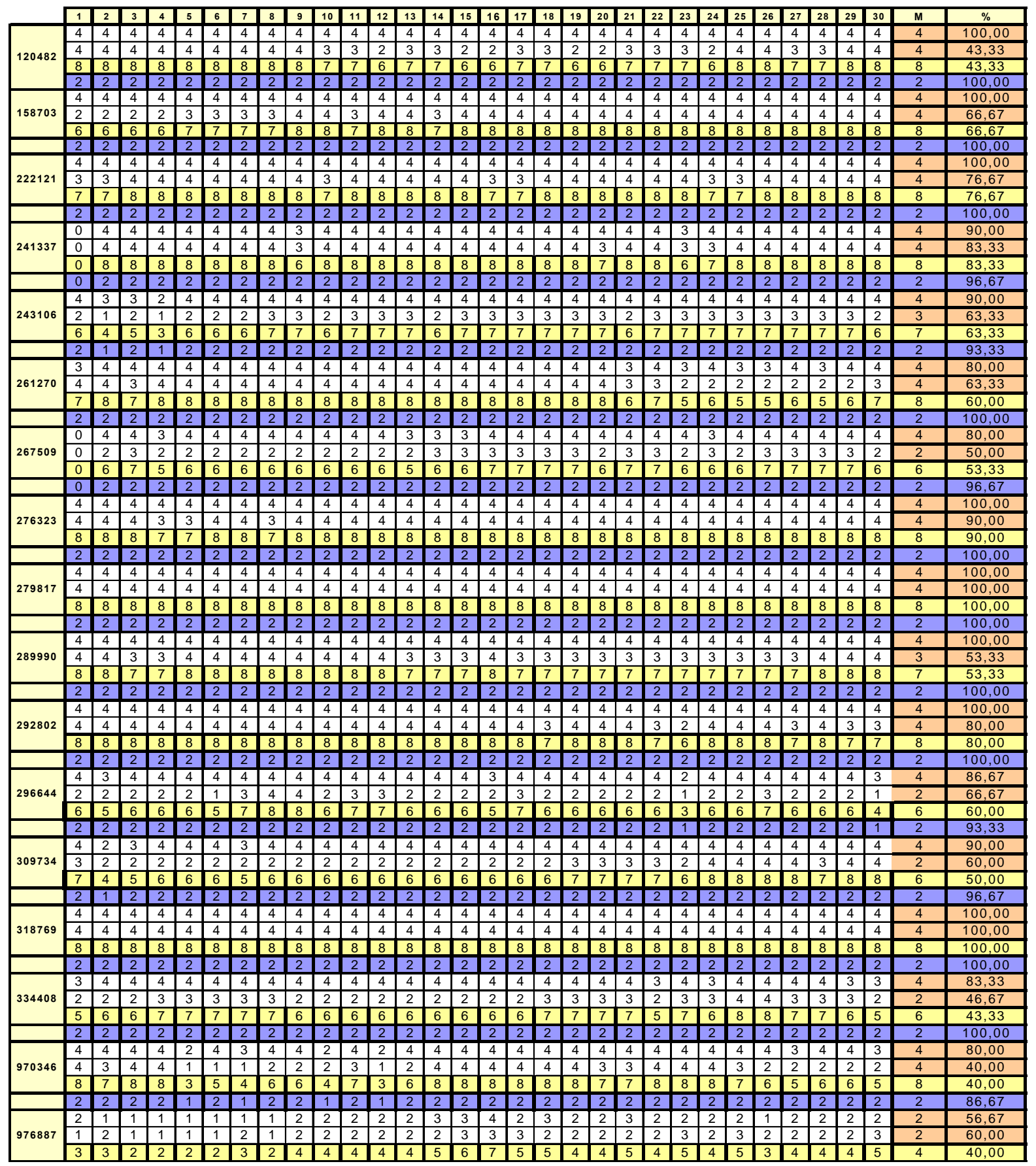

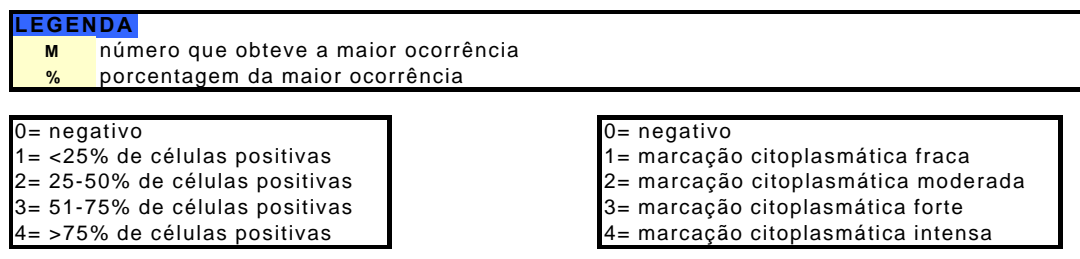


ANEXO 9 - Análise da expressão do Bcl-X nas células tumorais do grupo CEC

PLANILHA GRUPO 2 - BCL-X

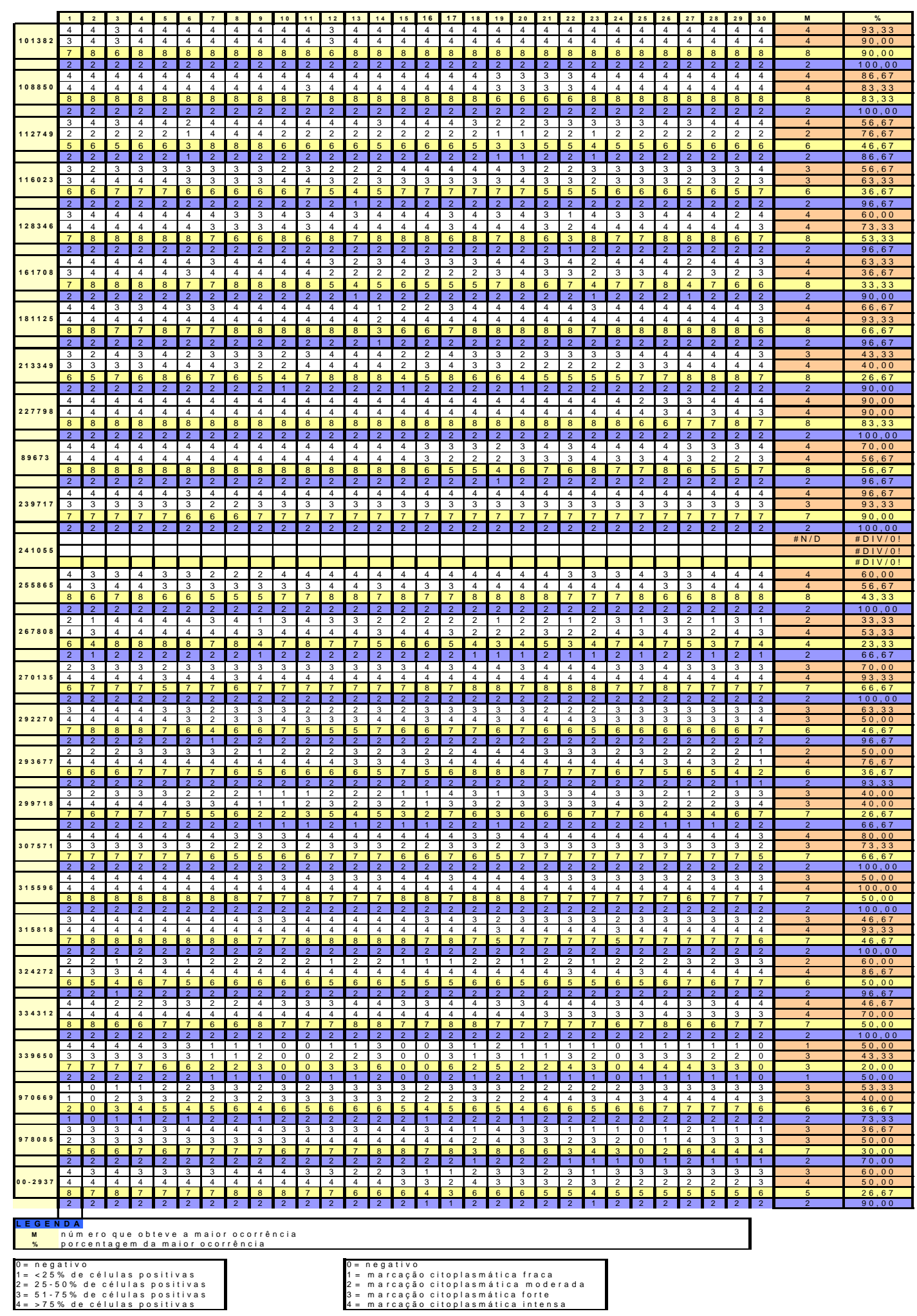


ANEXO 10 - Sobrevida global dos pacientes com carcinoma escamoso basalóide e com carcinoma espinocelular pouco diferenciado de boca, segundo marcação ao anticorpo Bax. Porcentagem de sobrevida acumulada pela técnica de KaplanMeier

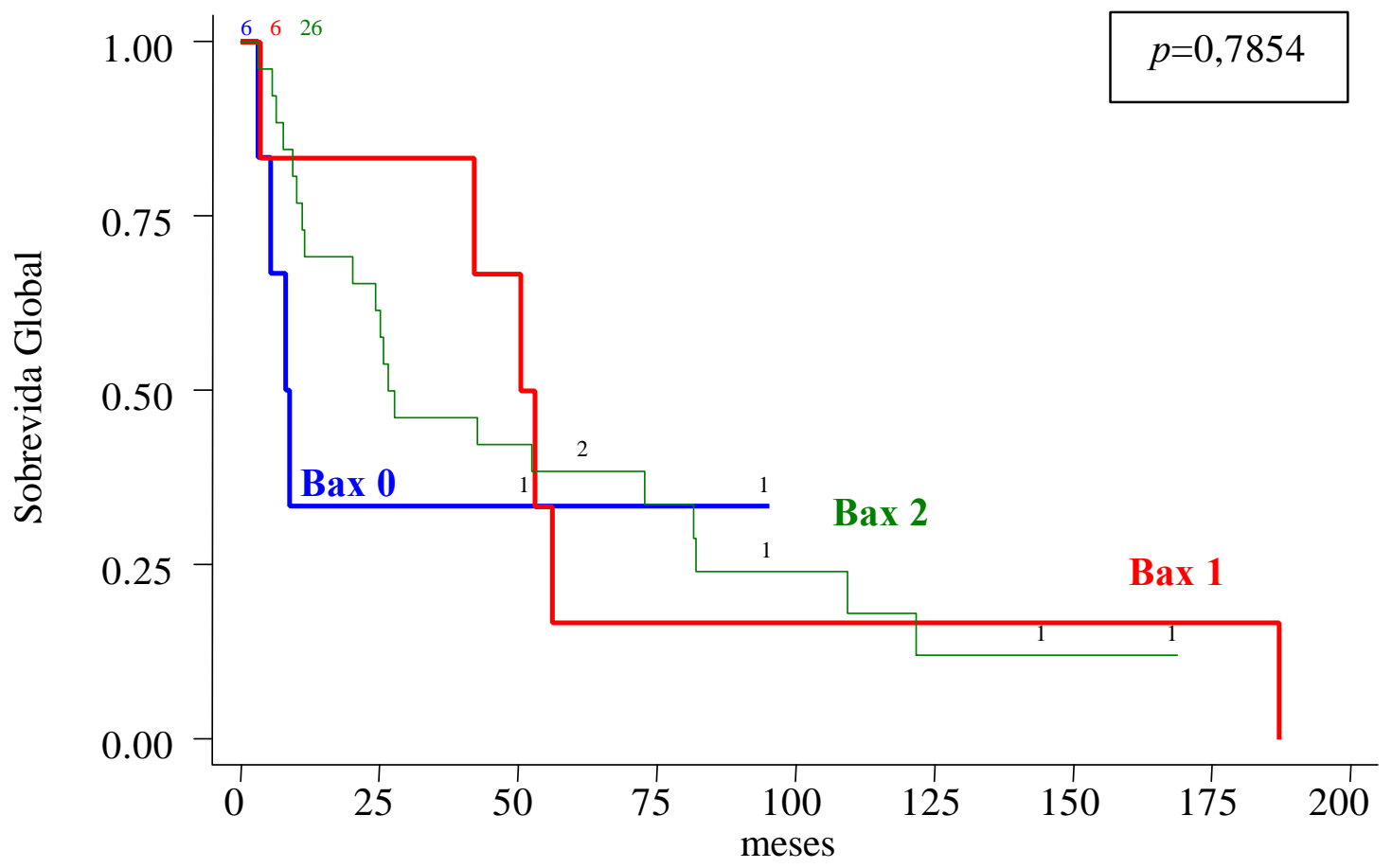


ANEXO 11 - Sobrevida global dos pacientes com carcinoma escamoso basalóide e com carcinoma espinocelular pouco diferenciado de boca, segundo marcação ao anticorpo Bax. Porcentagem de sobrevida acumulada pela técnica de KaplanMeier

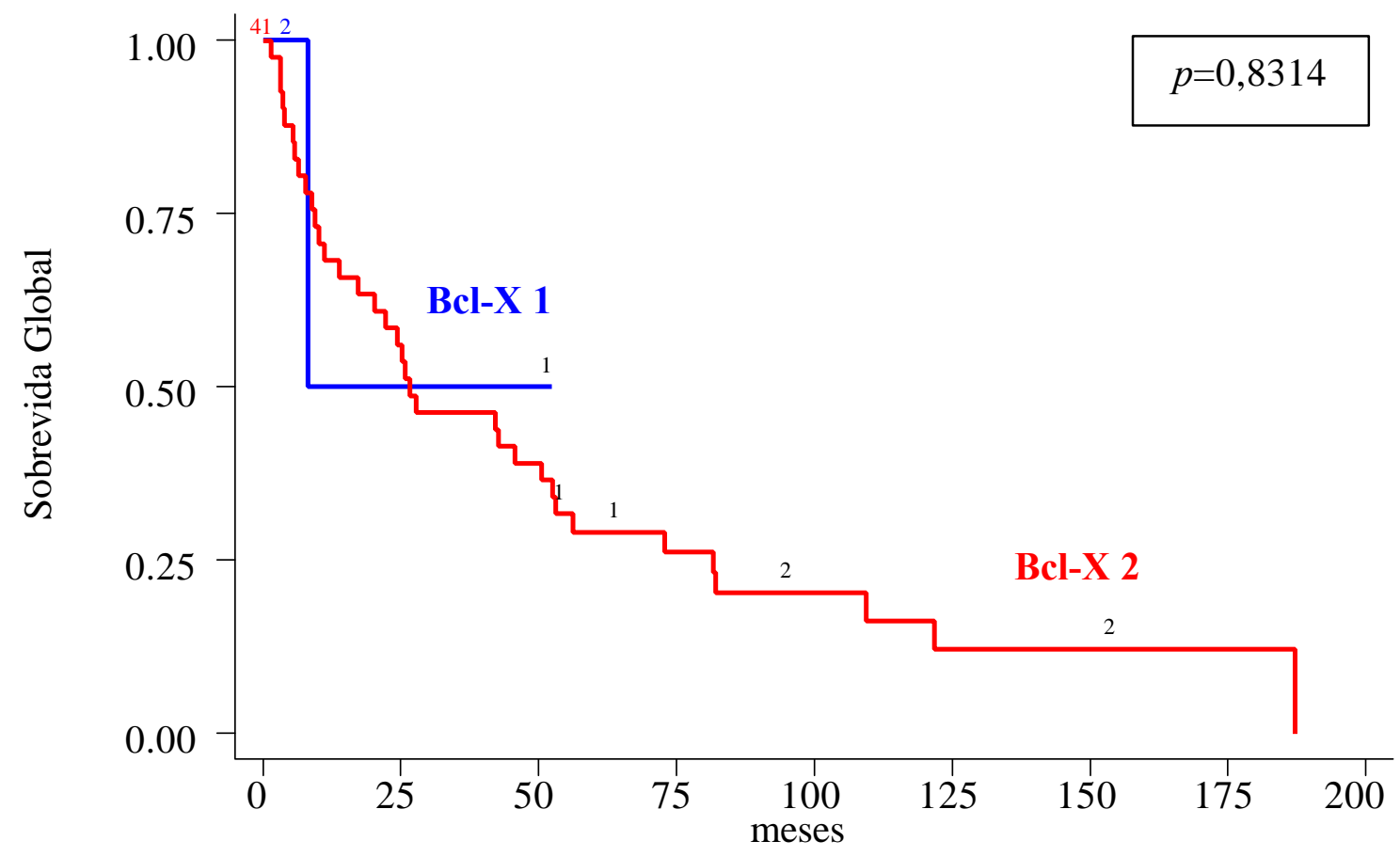


ANEXO 12 - Sobrevida global dos pacientes com carcinoma escamoso basalóide e com carcinoma espinocelular pouco diferenciado de boca, segundo marcação ao anticorpo PCNA. Porcentagem de sobrevida acumulada pela técnica de Kaplan-Meier

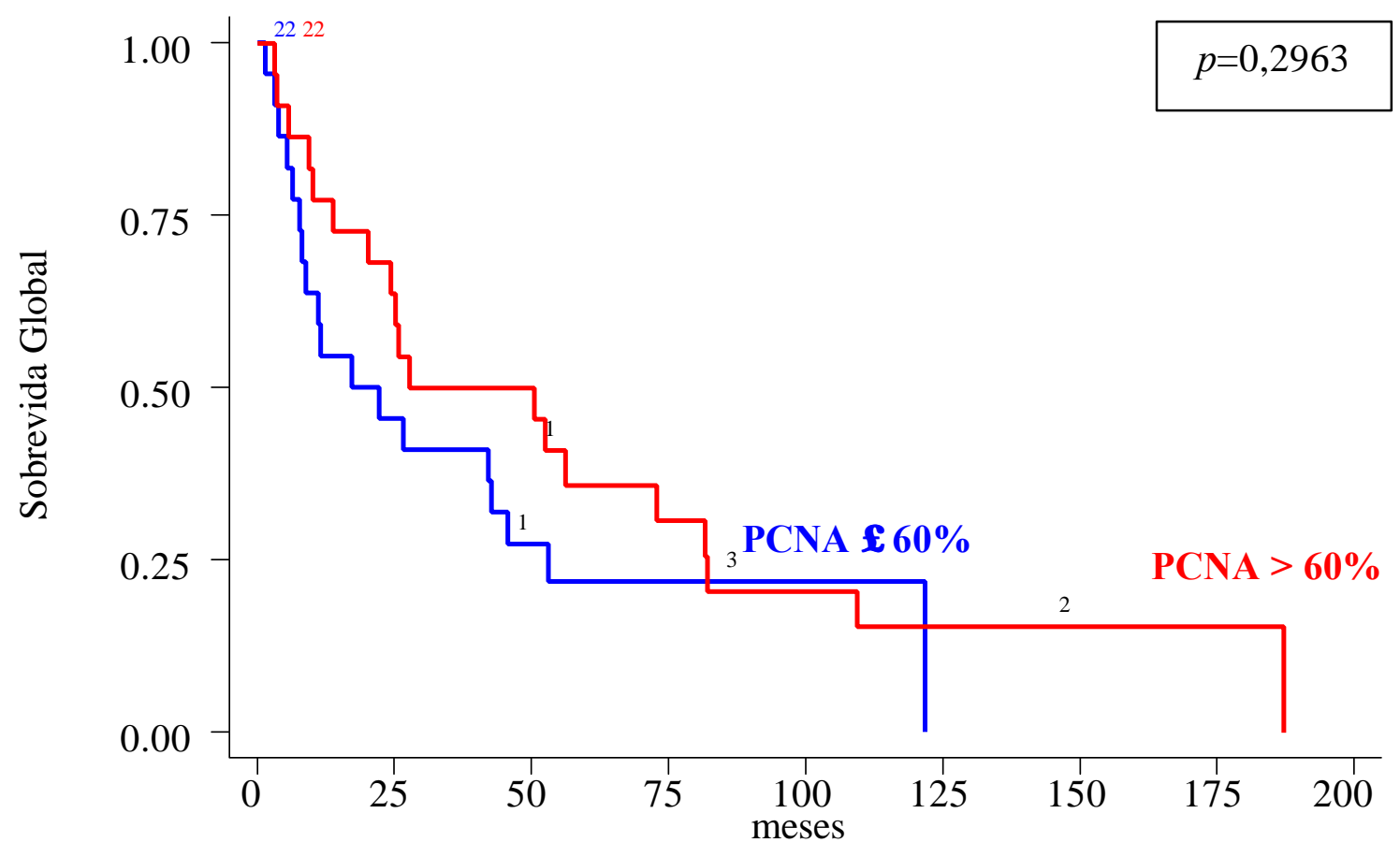


ANEXO 13 - Sobrevida global dos pacientes com carcinoma escamoso basalóide e com carcinoma espinocelular pouco diferenciado de boca, segundo marcação ao anticorpo p53. Porcentagem de sobrevida acumulada pela técnica de KaplanMeier

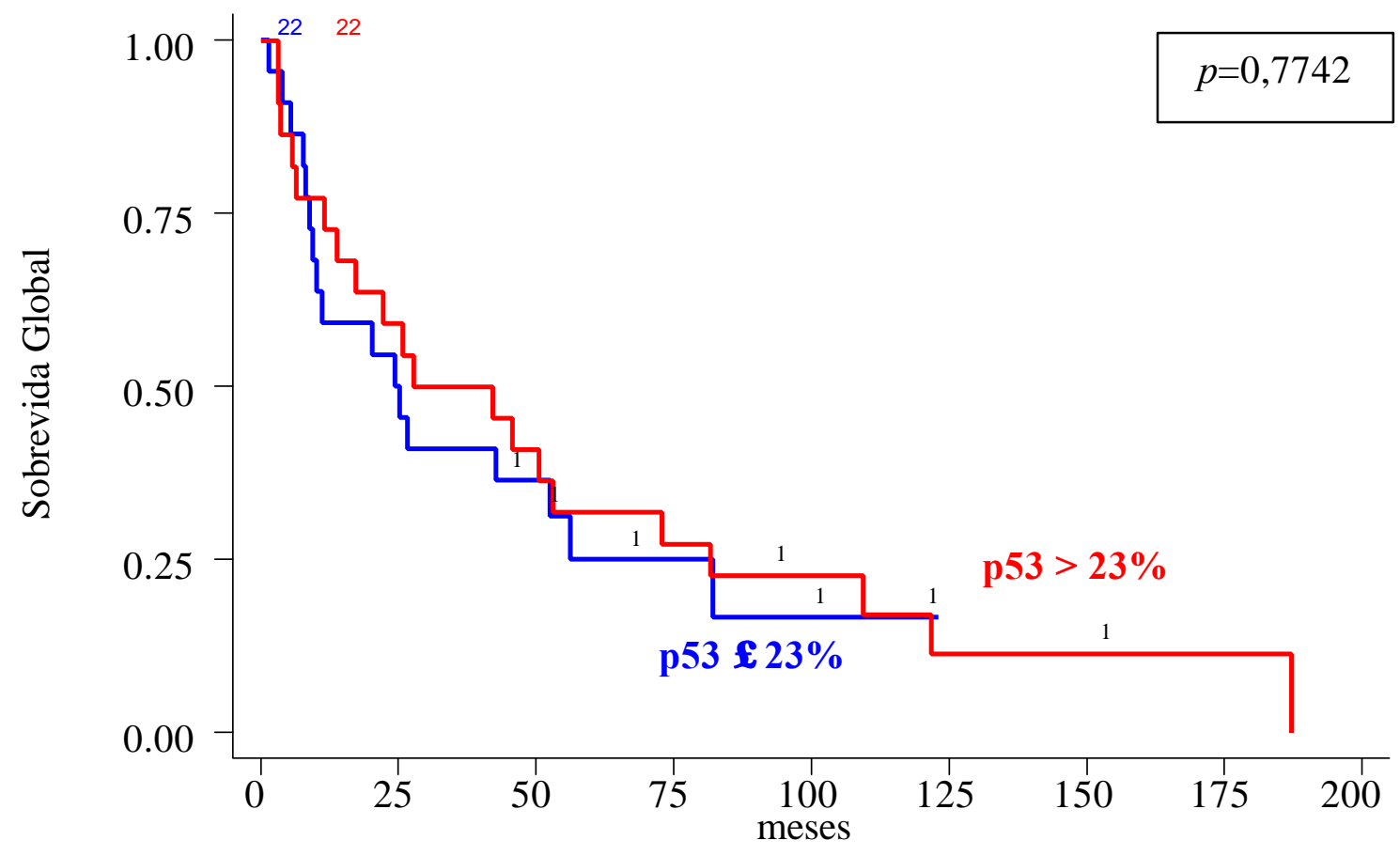


ANEXO 14 - Sobrevida específica dos pacientes com carcinoma escamoso basalóide e com carcinoma espinocelular pouco diferenciado de boca, segundo marcação ao anticorpo Bax. Porcentagem de sobrevida acumulada pela técnica de KaplanMeier

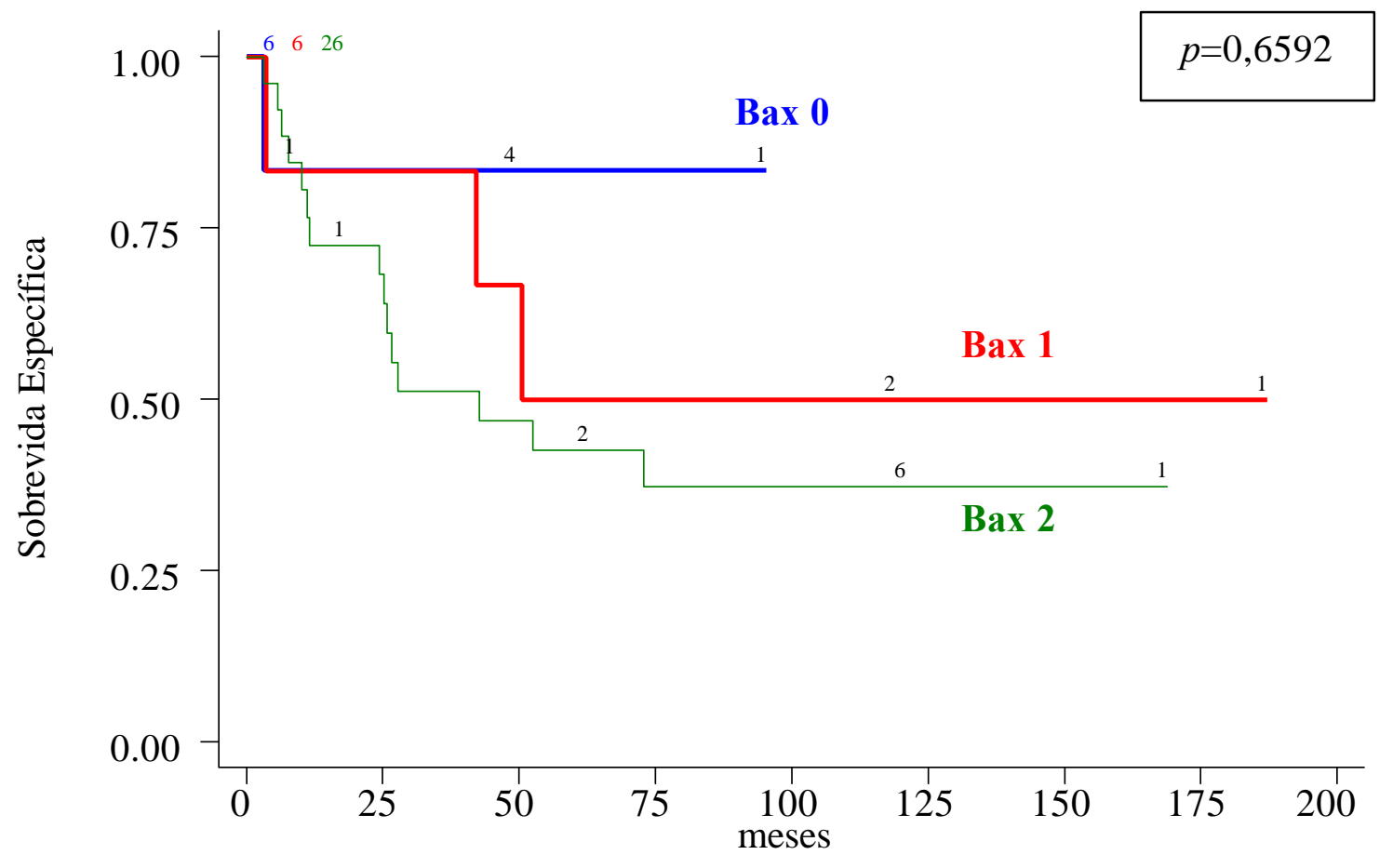


ANEXO 15 - Sobrevida específica dos pacientes com carcinoma escamoso basalóide e com carcinoma espinocelular pouco diferenciado de boca, segundo marcação ao anticorpo Bcl-X. Porcentagem de sobrevida acumulada pela técnica de KaplanMeier

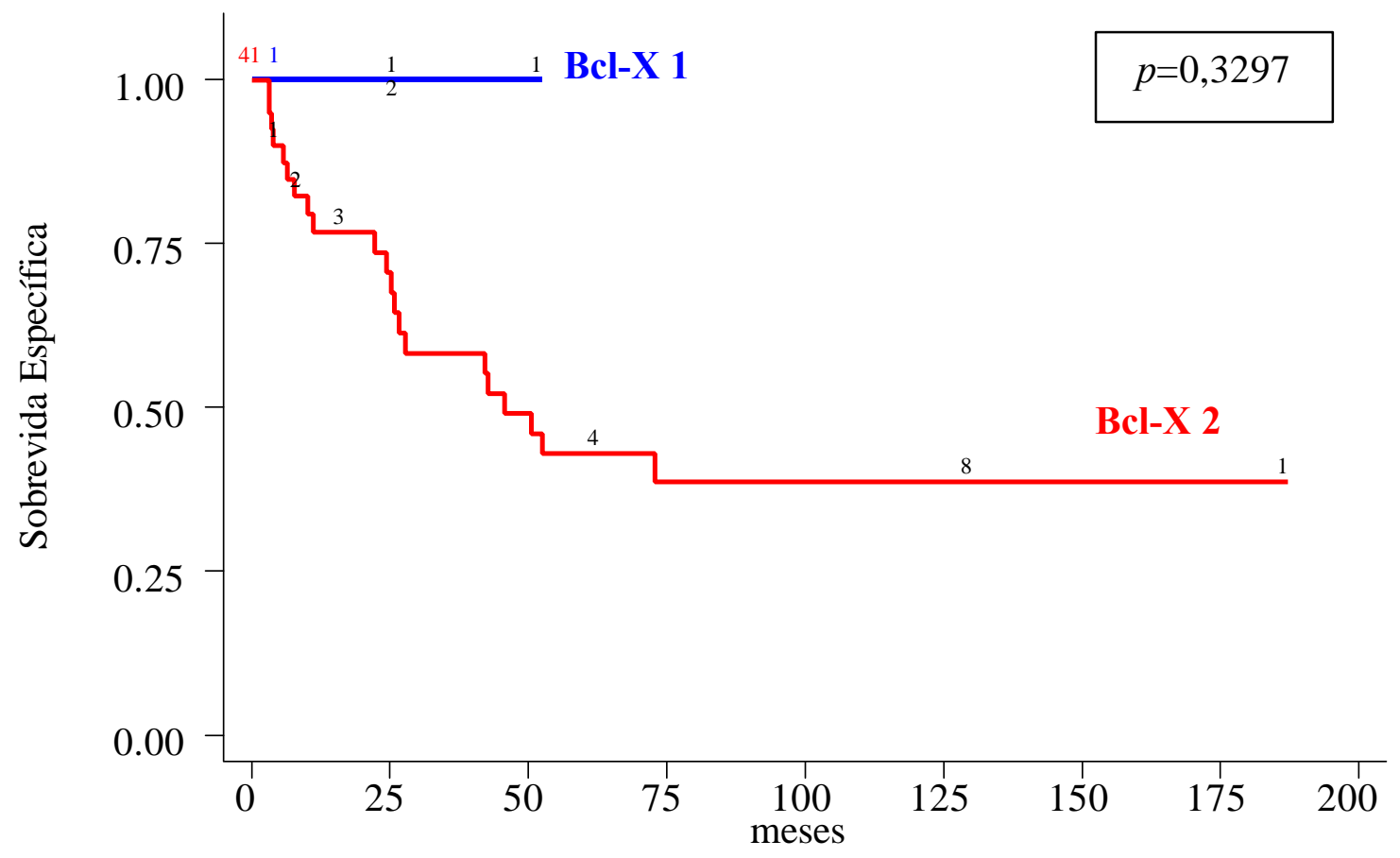


ANEXO 16: - Sobrevida específica dos pacientes com carcinoma escamoso basalóide e com carcinoma espinocelular pouco diferenciado de boca, segundo marcação ao anticorpo PCNA. Porcentagem de sobrevida acumulada pela técnica de Kaplan-Meier

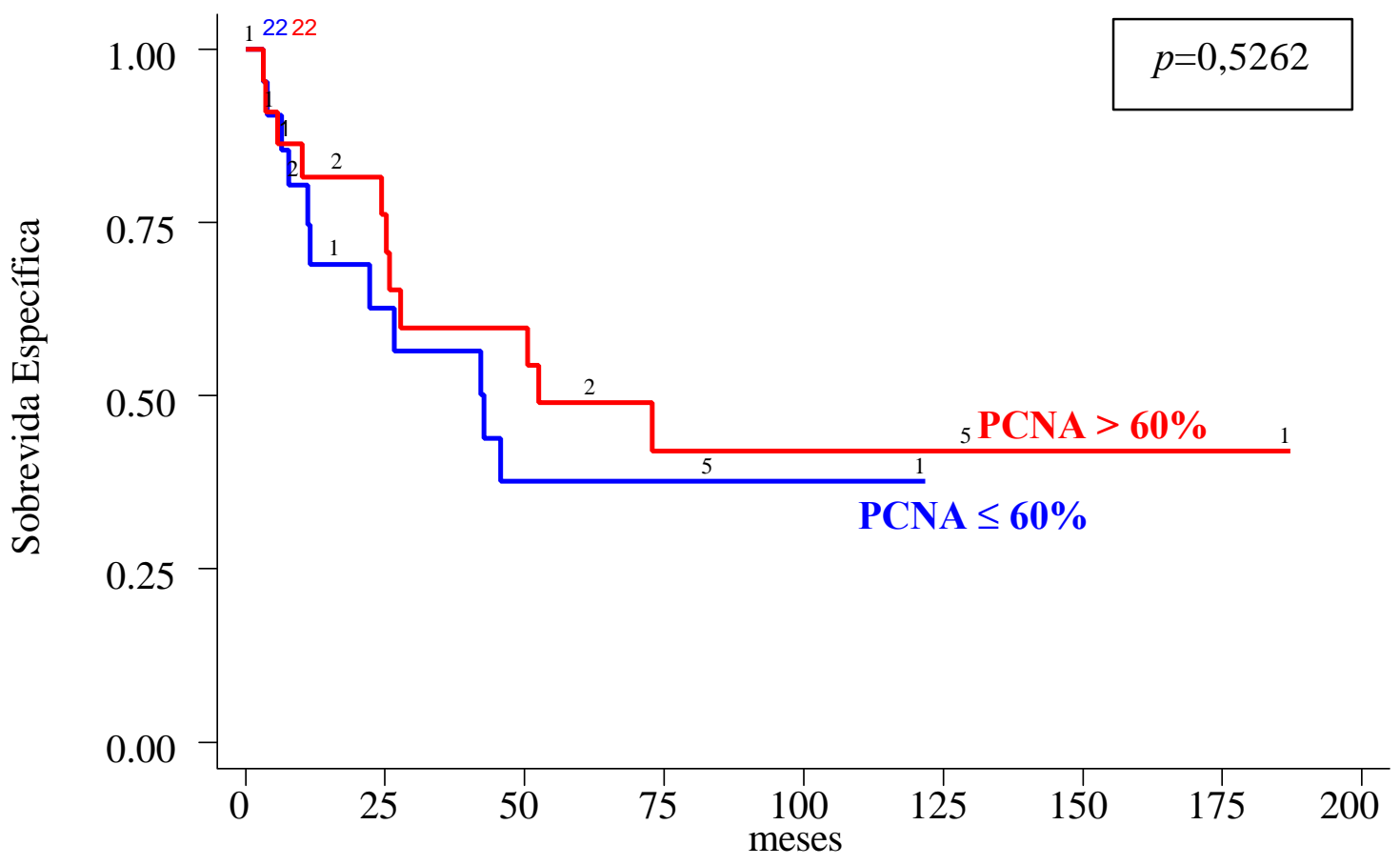


ANEXO 17 - Sobrevida específica dos pacientes com carcinoma escamoso basalóide e com carcinoma espinocelular pouco diferenciado de boca, segundo marcação ao anticorpo p53. Porcentagem de sobrevida acumulada pela técnica de KaplanMeier

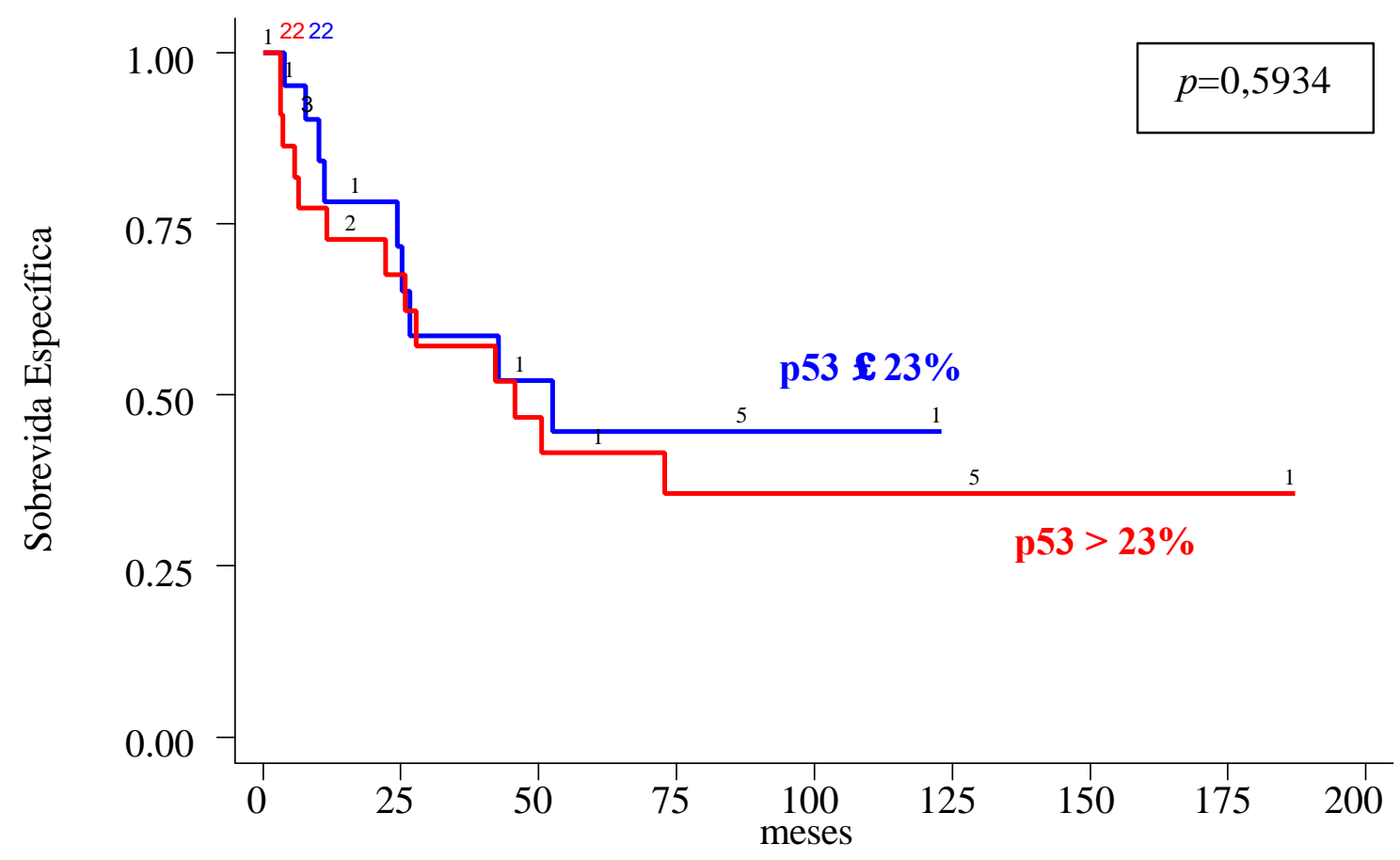


ANEXO 18 - Sobrevida livre de doença dos pacientes com carcinoma escamoso basalóide e com carcinoma espinocelular pouco diferenciado de boca, segundo marcação ao anticorpo Bax. Porcentagem de sobrevida acumulada pela técnica de Kaplan-Meier

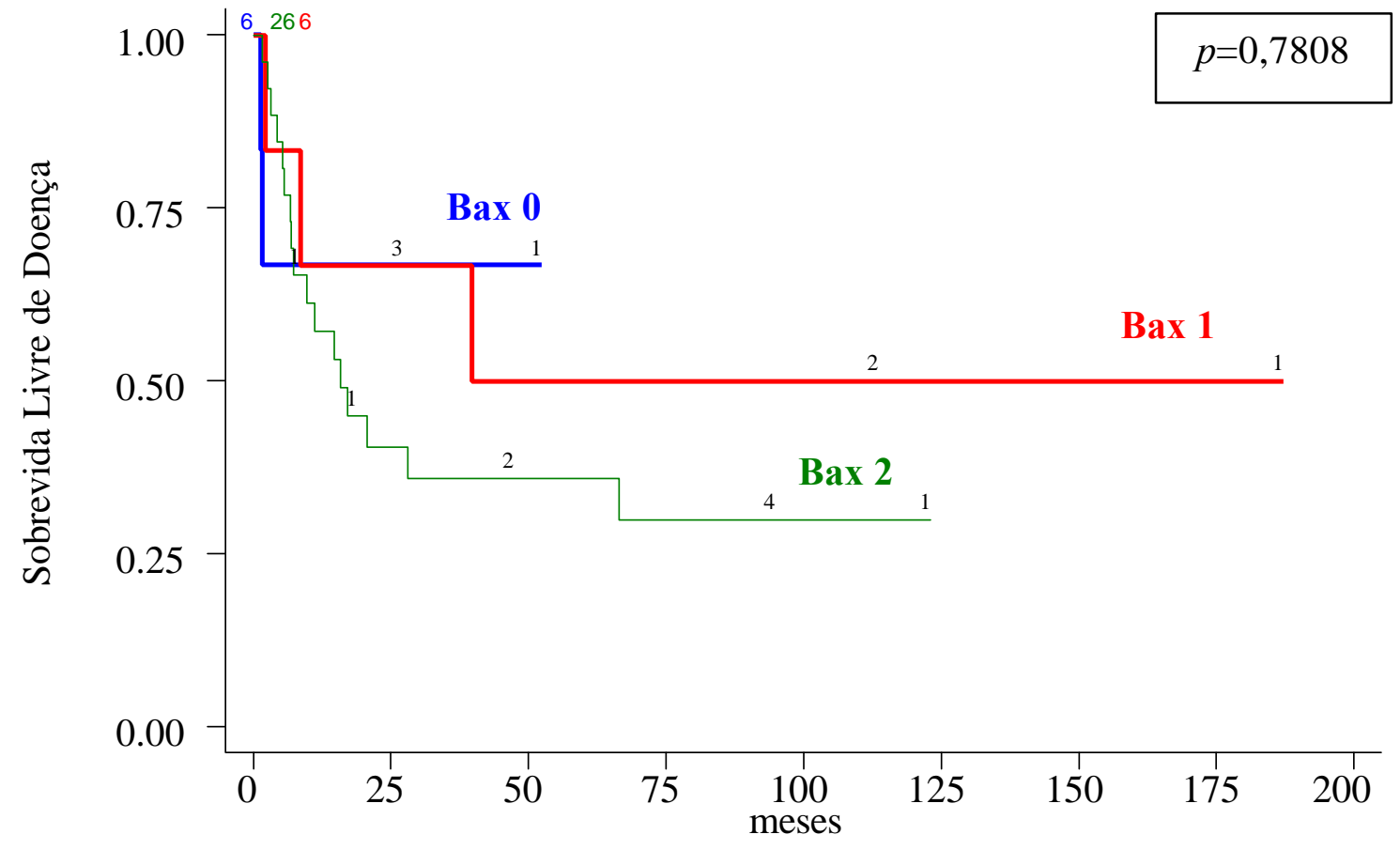


ANEXO 19 - Sobrevida livre de doença dos pacientes com carcinoma escamoso basalóide e com carcinoma espinocelular pouco diferenciado de boca, segundo marcação ao anticorpo Bcl-X. Porcentagem de sobrevida acumulada pela técnica de Kaplan-Meier

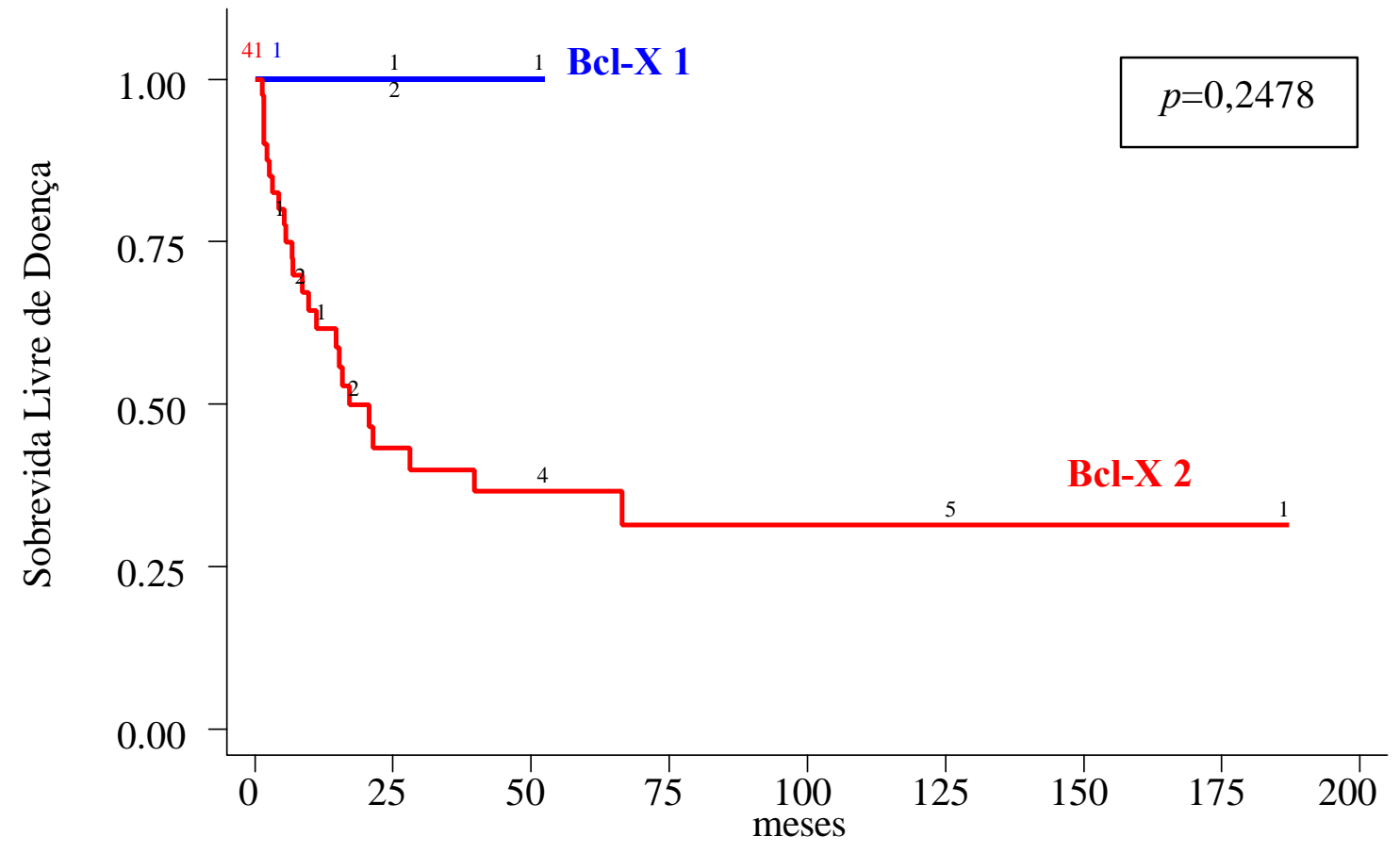


ANEXO 20 - Sobrevida livre de doença dos pacientes com carcinoma escamoso basalóide e com carcinoma espinocelular pouco diferenciado de boca, segundo marcação ao anticorpo PCNA. Porcentagem de sobrevida acumulada pela técnica de Kaplan-Meier

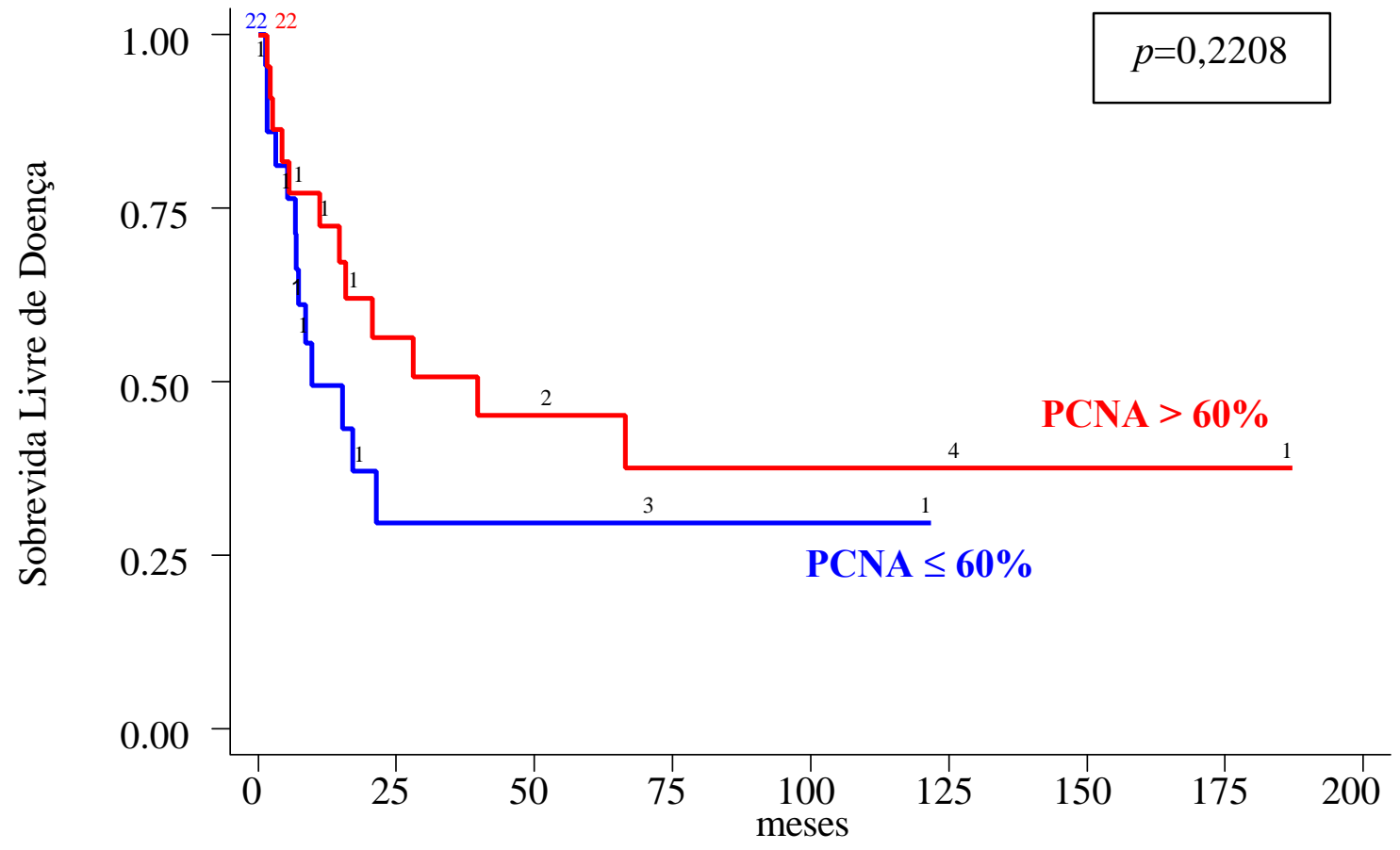


ANEXO 21 - Sobrevida livre de doença dos pacientes com carcinoma escamoso basalóide e com carcinoma espinocelular pouco diferenciado de boca, segundo marcação ao anticorpo p53. Porcentagem de sobrevida acumulada pela técnica de Kaplan-Meier

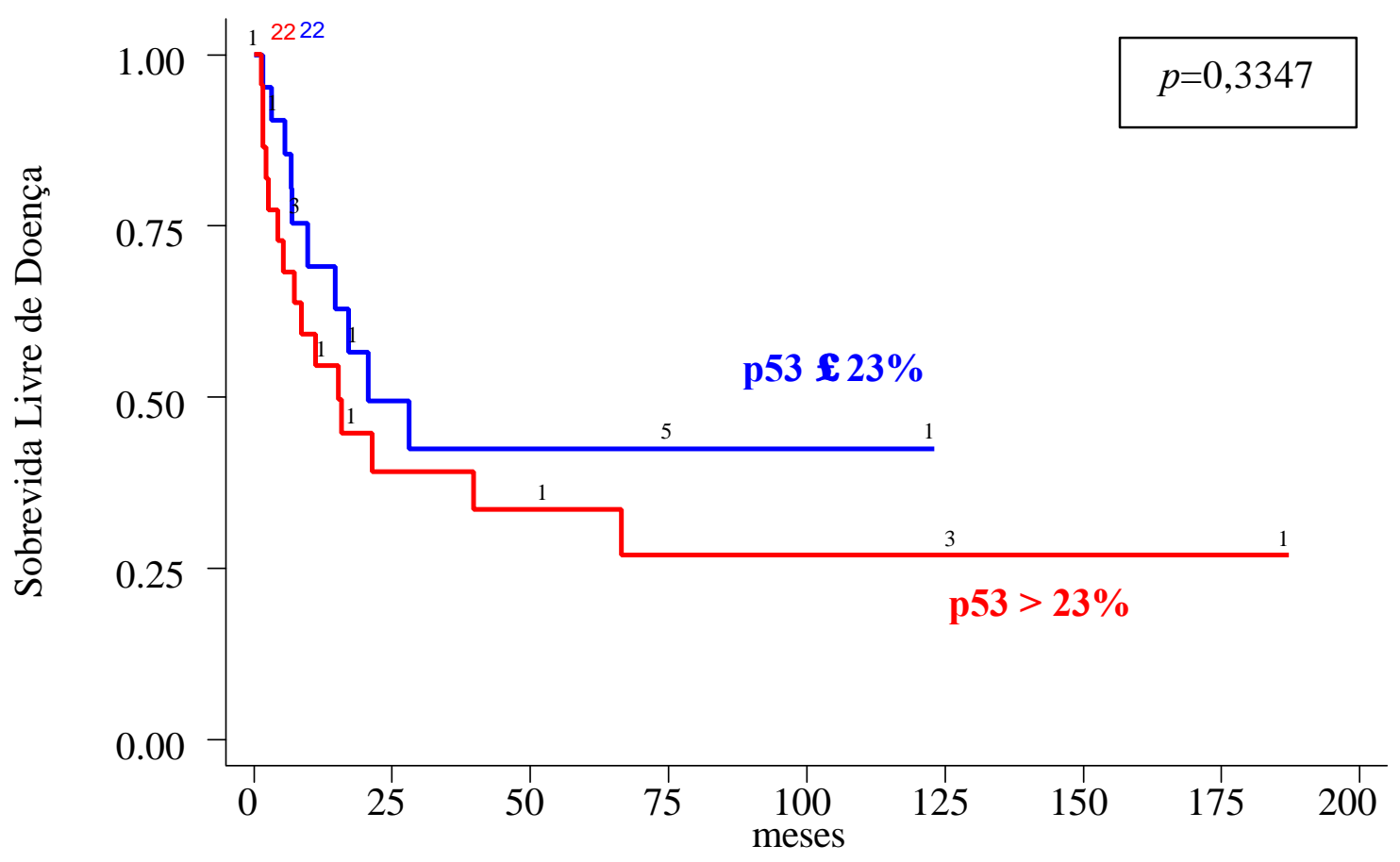


REFERÊNCIAS BIBLIOGRÁFICAS 


\section{REFERÊNCIAS BIBLIOGRÁFICAS*}

1. ABE, K. et al. Basaloid-squamous carcinoma of the esophagus. A clinicopathologic, DNA ploidy, and immunohistichemical study of seven cases. Amer. J. surg. Path., v.20, n.4, p.453-61, Apr. 1996.

2. ABIKO, Y. et al. Basaloid-squamous cell carcinoma of the floor of the mouth: characterization of a cell line. J. oral Path. Med., v.26, n.8, p.367-70, Sept. 1997.

3. ABIKO, Y. et al. Basaloid-squamous cell carcinoma of the oral mucosa: report of two cases and study of the proliferative activity. Pathol. Int., v.48, n.6, p.460-6, June 1998.

4. AGARWAL, S. et al. MDM2/p53 co-expression in oral premalignant and malignant lesions: potential prognostic implications. Oral Oncol., v.35, n.2, p.209-16, Mar. 1999.

5. AKAO, Y. et al. Multiple subcellular localization of blc-2: detection in nuclear outer membrane, endoplasmic reticulum membrane, and mithochondrial membranes. Cancer Res., v.54, p.2468-71, May 1994.

6. AKYOL, M.U. et al. Proliferation cell nuclear antigen immunoreactivity and the presence of p53 mutation in basaloid squamous cell carcinoma of the larynx. Oncology, v.55, n.5, p.382-3, Sept. 1998.

7. ALTAVILLA, G. et al. Basaloid squamous cell carcinoma of the oral cavity and oropharynx. ORL - Otorhinolaryngology Relat. Spec., v.61, n.3, p.169-73, May/June 1999.

8. ANNEROTH, G.; HANSEN, L. A methodologic study od histologic classification and grading of malignancy in oral squamous cell carcinoma. Scand. J. dent. Res., v.92, p.448-68, 1984.

9. ARAÚJO, V.C. et al. Basaloid squamous carcinoma of the oral cavity. Report of a case. Oral Surg., v.75, n.5, p.622-25, May 1993.

10. BABÓ, I. et al. The pathomorphology of a human xenotransplanted basaloid squamous cell carcinoma. Neoplasma, v.45, n.4, p.210-5, 1998.

\footnotetext{
* Normas recomendadas para o uso no âmbito da Universidade de São Paulo, com base no documento "Referências Bibliográficas: exemplos" emanado do Conselho Supervisor do Sistema de Bibliotecas da USP, em reunião de 20 de setembro de 1990.
} 
11. BABÓ, I.; BOSCI, J.; JENEY, A. The site-dependent growth characteristics of a human xenotransplanted basaloid squamous cell carcinoma. J. Cancer Res. Clin. Oncol., v.125, n.1, p.35-41, 1999.

12. BÀNKFALVI, A.; PIFFKÒ, J. Prognostic and predictive factors in oral cancer: the role of invasive tumor front. J. oral Path. Med., v.29, n.7, p.291-8, Aug. 2000.

13. BANKS, E.R. et al. Basaloid squamous cell carcinoma of the head and neck. A clinicopathologic and immunohistochemical study of 40 cases. Amer. J. surg. Path., v.16, n.10, p.936-46, Oct. 1992.

14. BARNES, L. et al. Basaloid squamous cell carcinoma of the head and neck: clinicopathological features and differential diagnosis. Ann. Otol., v.105, n.1, p.7582, Jan. 1996.

15. BATSAKIS, J.; NAGGAR, A.E. Basaloid-squamous carcinoma of the upper aerodigestive tracts. Ann. Otol., v.98, n.11, p.919-20, Nov. 1989.

16. BOISE, L.H. Bcl-X, a bcl-2-related gene that functions as a dominant regulator of apoptotic cell death. Cell, v.74, p.597-608, Aug. 1993.

17. BRACERO, F. et al. Carcinoma basaloide escamoso de laringe e hipofaringe: presentación de uma serie de 6 casos. Acta otolaringol. esp., v.52, n.3, p.229-36, Apr. 2001.

18. BRAMBILLA, E. et al. Basal cell (Basaloid) carcinoma of the lung. A new morphologic and phenotypic entity with separate prognostic significance. Human Path., v.23, n.9, p.993-1003, 1992.

19. BRYNE, M. et al. Malignant grading of the deep invasive margins of oral squamous cell carcinomas has high prognostic value. J. Path., v.166, n.4, p.375-81, Jan. 1992.

20. BRYNE, M. Is the invasive front of an carcinoma the most important area for prognostication? Oral Dis., v. 4, p.70-7, 1998.

21. CADIER, M.A. et al. Basaloid squamous carcinoma of the buccal cavity. Head Neck, v.14, n.5, p.387-91, Sept./Oct. 1992.

22. CAMPMAN, S.C.; GANDOUR-EDWARDS, R.F.; SYKES, J.M. Basaloid squamous carcinoma of the head and neck. Report of a case occurring in the anterior floor of the mouth. Arch. Path. Lab. Med., v.118, n.2, p.1229-32, Dec. 1994.

23. CHO, K.J. et al. Basaloid squamous carcinoma of the oesophagus: a distinct neoplasm with multipotencial differentiation. Histopathology, v. 36, n.4, p.331-40, Apr. 2000. 
24. COLETTA, R.D. et al. Basaloid squamous carcinoma of the oral cavity: report of 2 cases and study of AgNOR, PCNA, p53, and MMP expression. Oral Surg., v.91, n.5, p.563-69, May 2001.

25. COLETTA, R.D. et al. Basaloid squamous carcinoma of the oral cavity: a histologic and immunohistochemical study. Oral Oncol., v.38, n.7, p.723-9, Oct. 2002.

26. COPPOLA, D. et al. Basaloid squamous cell carcinoma of floor of the mouth. Cancer, v.72, n.8, p.2299-305, Oct. 1993.

27. COSTA, A. et al. Biological markers as indicators of pathological response to primary chemotherapy in oral cavity cancers. Int. J. Cancer, v. 79, n.6, p.619-23, Dec. 1998.

28. COTRIM-ZÚÑIGA, A.P. Análise histopatológica e estudo da expressão de PCNA, p53, e de metaloproteinases de matriz no carcinoma basalóide escamoso da cavidade oral. Campinas 2001. Dissertação (Mestrado) - Universidade Estadual de Campinas, Faculdade de Odontologia de Piracicaba.

29. COX, D.R. Regression models on life tables. J. R. Stat. Soc., v.34, p.187-220, 1972.

30. CUBILLA. A.L. et al. Histologic classification of penile carcinoma and its relation to outcome in 61 patients with primary resection. Int. J. Surg. Path., v.9, n.2, p.11120, Apr. 2001.

31. EREÑO, C. et al. Basaloid-squamous cell carcinoma of the larynx and hypopharynx. A clinicopathologic study of 7 cases. Path. Res. Pract., v.190, n.2, p.186-94, Feb. 1994.

32. FERLITO, A. et al. Mucosal adenoid squamous cell carcinoma of the head and neck. Ann. Otol., v.105, n.5, p.409-13, May 1996.

33. FERLITO, A.; DEVANEY, K.O.; RINALDO, A. Squamous neoplastic component in unconventional squamous cell carcinomas of the larynx. Ann. Otol., v.105, n.11, p.926-35, Nov. 1996.

34. FERLITO, A. et al. Basaloid squamous cell carcinoma of the larynx and hypopharynx. Ann. Otol., v.106, n.12, p.1024-35, Dec. 1997.

35. FRIEDMAN, M. et al. Prognostic significance of Bcl-2 expression in localized squamous cell carcinoma of the head and neck. Ann. Otol, v.106, n.6, p.445-50, June 1997.

36. GALLO, O. et al. Bcl-2 protein expression correlates with recurrence and survival in early stage head and neck cancer treated by radiotherapy. Clin. Cancer Res., v.2, n.2, p.261-7, 1996. 
37. GALLO, O. et al. Cumulative prognostic value of p53 mutations and Bcl-2 protein expression in head and neck cancer treated by radiotherapy. Int. J. Cancer, v.84, p.573-9, 1999.

38. GILLESPIE, J.J.; MAC KAY, B. Histogenesis of cloacogenic carcinoma. Human Pathol., v.9, n.5, p.579-87, Sept. 1978.

39. GIROD, S.C. et al. Proliferative activity and loss of function of tumour supressor genes as "biomarkers" in diagnosis and prognosis of benign and preneoplastic oral lesions and oral squamous cell carcinoma. Brit. J. oral Maxillofac. Surg., v.36, n.4, p.252-60, Aug. 1998.

40. GLUCKMAN, J.L. et al. Prognostic indicators for squamous cell carcinoma of the oral cavity: a clinocopathologic correlation. Laryngoscope, v.107, n.9, p.1239-44, Sept. 1997.

41. GONZALEZ-MOLES, M.A. p53 protein expression in oral squamous cell carcinoma. Survival analysis. Anticancer Res., v. 21, n.4B, p.2889-94, July/Aug. 2001.

42. GRAYSON, W.; TAYLOR, L.F.; COOPER, K. Adenoid cystic and adenoid basal carcinoma of the uterine cervix. Amer. J. surg. Path., v.23, n.4, p.448-58, Apr. 1999.

43. HELLQUIST, H.B. et al. Basaloid squamous cell carcinoma of the palate. Histopathology, v.25, p.178-80, Aug. 1994.

44. HENGARTNER, M.O. The biochemistry of apoptosis. Nature, v.407, p.770-6, Oct. 2000.

45. HEWAN-LOWE, K.; DARDICK, I. Ultrastructural distinction of basaloid-squamous carcinoma and adenoid cystic carcinoma. Ultrastruct. Path., v.19, n.5, p.371-81, Sept./Oct. 1995.

46. HIRANUMA, H. et al. An analysis of the prognostic significance of p53 status for squamous cell carcinoma of the oral cavity treated by radiotherapy. Oral Oncol., v.34, n.6, p.513-8, Nov. 1998.

47. HOMMA, A. et al. Prognostic significance of clinical parameters and biological markers in patients with squamous cell carcinoma of the head and neck treated with concurrent chemoradiotherapy. Clin. Cancer Res., v.5, n.4, p801-6, Apr. 1999.

48. HUANG, D.C.S. et al. The anti-apoptotic function of Bcl-2 can be genetically separated from its inhibitory effect on cell cycle entry. ЕМBO J., v.16, n.15, p.4628-38, 1997. 
49. HUANG, J.S. et al. MDM2 expression in areca quid chewing-associated oral squamous cell carcinomas in Taiwan. J. oral Path. Med., v.30, n.1. p.53-8, Jan. 2001.

50. IDE, F. et al. Polypoid carcinoma of the tongue. J. oral Path. Med., v.25, n.2, p.90-2, Feb. 1996.

51. IDE, F. et al. Basaloid squamous cell carcinoma of the esophagus metastatic to the gingiva. A case report. Oral Surg., v.83, n.5, p.584-7, May 1997.

52. IDE, F. et al. Basaloid squamous cell carcinoma of the oral mucosa: a new case and review of 45 cases in the literarure. Oral Oncol., v.38, n.1, p.120-4, 2002.

53. KANTOLA, S. et al. Prognostic factors in tongue cancer-relative importance of demografic, clinical and histopathological factors. Brit. J. Cancer, v. 83, n.5, p.6149, 2000.

54. KAPLAN, E.L.; MEIER, P. Nonparametric estimation from incomplete observations. J. Amer. Stat. Ass., v.53, p.457-81, 1958.

55. KAPRANOS, N. et al. p53, p21 and p27 protein expression in head and neck cancer and their prognostic value. Anticancer Res., v.21, n.1B, p.521-8, Jan./Feb. 2001.

56. KAWAHARA, K. et al. An immunohistichemical examination of basaloid squamous cell carcinoma of the esophagus: report of a case. Surg. Today, v.31, n.7, p.655-9, 2001.

57. KIM, J.Y. et al. Clinicopathologic study of basaloid squamous carcinoma of the upper aerodigestive tract. J. Korean Med. Sci., v.13, n.3, p.269-74, June 1998.

58. KLIJANIENKO, J. et al. Basaloid squamous carcinoma of the head and neck. Immunohistochemical comparision with adenoid cystic carcinoma and squamous cell carcinoma. Arch. Otolaryng. head neck Surg., v.119, n.8, p.887-90, Aug. 1993.

59. KOELBL, O. et al. p53 and Ki-67 as predictive markers for radiosensitivity in squamous cell carcinoma of the oral cavity. An immunohistochemical and clinicopathological study. Int. J. Radiat. Biol., v.49, n.1, p.147-54, Jan. 2001.

60. KOIDE, N. et al. Immunohistochemical expression of Bcl-2 protein in squamous cell carcinoma and basaloid carcinoma of the esophagus. Surg. Today, v.27, n.8, p.68591, 1997.

61. KOONTONGKAEW, S. et al. Alterations of p53, pRb, cyclin D1 and cdk4 in human oral and pharyngeal squamous cell carcinomas. Oral Oncol., v.36, n.4, p.334-9, July 2000. 
62. KOWALSKI, L.P. et al. Factors influencing contralateral lynph node metastasis from oral carcinoma. Head Neck, v.21, p.104-10, Mar. 1999.

63. KRAJEWSKI, S. et al. Investigation of the subcellular distribution of the Bcl-2 oncoprotein: residence in the nuclear envelope, endoplasmic reticulum, and outer mithochondrial membranes. Cancer Res., v. 53, p.4701-14, Oct. 1993.

64. KROPVELD, A. et al. Sequencing analysis of RNA and DNA of exons1 through 11 shows $p 53$ gene alterations to be present in almost $100 \%$ of head and neck squamous cell cancers. Lab. Invest., v.79, n.3, p.347-55, 1999.

65. LAM, K.Y. et al. Cyclin D1 expression in oral squamous cell carcinomas: clinicopathological relevance and correlation with p53 expression. J. oral Path. Med., v. 29, n.4, p.167-72, Apr. 2000.

66. LAM, K.Y. et al. Oesophageal basaloid squamous cell carcinoma: a unique clinicopathologic entity with telomerase activity as a prognostic indicator. J. Path., v.195, n.4, p.435-42, Nov. 2001.

67. LANE, D.P. p53, guardian of the genome. Nature, v.358, p.15-6, July 1992.

68. LARNER, J.M. et al. Radiotherapy for basaloid squamous cell carcinoma of the head and neck. Head Neck, v.15, n.3, p.249-52, May 1993.

69. LEVINE, A.J.; MOMAND, J.; FINLAY, C.A. The p53 tumor suppressor gene. Nature, v.351, p.453-6, June 1991.

70. LI, X.J. et al. MDM2 overexpression with alteration of the p53 protein and gene status in oral carcinogenesis. Jpn. J. Cancer Res., v.91, n.5, p.492-8, May 2000.

71. LOPES, M.A. et al. Biomarkers predictive of lymph node metastases in oral squamous cell carcinoma. J. oral Maxillofac. Surg., v.60, n.2, p.142-7, Feb. 2002.

72. LORO L.L. et al. Oral squamous cell carcinoma in associated with decreased bcl-2/bax expression ration and increased apoptosis. Human Path., v.30, n.9, p.10971105, Sept. 1999.

73. LOVEJOY et al. Basaloid-squamous carcinoma of the palate. Otolaryng. Head Neck Surg., v.106, n.2, p.159-62, Feb. 1992.

74. LUNA, M.A. et al. Basaloid squamous carcinoma of the upper aerodigestive tract. Clinicopathologic and DNA flow cytometric analysis. Cancer, v.66, n.3, p.537-42, Aug. 1990. 
75. MCKAY, M.J.; BILOUS, A.M. Basaloid-squamous carcinoma of the hypopharynx. Cancer, v.63, n.12, p.2528-31, June 1989.

76. MESE, H. et al. Regulation of apoptosis reduction in the cisplatin-resistant A431 cell line by Bcl-2 and CPP32. Chemotherapy, v. 46, p. 46-69, 2000.

77. MIYASHITA, T. et al. Tumor suppressor p53 is a regulator of bcl-2 and bax gene expression in vitro and in vivo. Oncogene, v. 9, p.1799-1805, 1994.

78. MIYASHITA, T.; REED, J.C. Tumor supressor p53 is a direct transcriptional activator of the human bax gene. Cell, v.80, n.2, p.293-9, Jan. 1995.

79. MORO, D. et al. Basaloid bronchial carcinoma. A histological group with a poor prognosis. Cancer, v.73, n.11, p.2734-9, June 1994.

80. MULLER, S.; BARNES, L. Basaloid squamous cell carcinoma of the head and neck with spindle cell component. An unusual histologic variant. Arch. Path. Lab. Med., v.119, n.2, p.181-2, Feb 1995.

81. NARESH, K.N. et al. Apoptosis index is a predictor of metastatic phenotype in patients with early stage squamous cell carcinoma of the tongue. Cancer, v.91, n.3, p.578-84, Feb. 2001.

82. NG, I.O.L. et al. Expression of p21/waf1 in oral squamous cell carcinomas - correlation with p53 and mdm2 and cellular proliferation index. Oral Oncol., v.35, n.1, p.63-9, Jan. 1999.

83. NISHIOKA, H. et al. Immunohistochemical detection of p53 oncoprotein in human oral squamous cell carcinomas and leukoplakias: comparision with proliferating cell nuclear antigen staining and correlation with clinicopathological findings. Oncology, v.50, n.6, p.426-9, Nov./Dec. 1993.

84. NOUTOMI, T. et al. Bcl- $\mathrm{X}_{\mathrm{L}}$ confers multi-drugs resistance in several squamous cell carcinoma cell lines. Oral Oncol., v.38, n.1, p.41-8, Jan. 2002.

85. NYLANDER, K. et al. p53 expression and cell proliferation in squamous cell carcinomas of the head and neck. Cancer, v.75, n.1, p.87-93, Jan. 1995.

86. NYLANDER, K. et al. p53 mutations, protein expression and cell proliferation in squamous cell carcinomas of the head and neck. Brit. J. Cancer, v.71, n.4, p.826-30, Apr. 1995. 
87. NYLANDER, K.; DABELSTEEN, E.; HALL, P.A. The p53 molecule and its prognostic role in squamous cell carcinomas of the head and neck. J. oral Path. Med., v.29, n.9, p.413-52, Oct. 2000.

88. OLTAVAI, Z.N.; MILLIMAN, C.L.; KORSMEYER, S.J. Bcl-2 heterodimerizes in vivo with a conserves homolog, Bax, that accelerates programed cell death. Cell, v.74, p.609-19, Aug. 1993.

89. OSTWALD, C. et al. p53 mutational spectra are different between squamous-cell carcinomas of the lip and the oral cavity. Int. J. Cancer, v.88, n.1, p.82-6, Oct. 2000.

90. OWONIKOKO, T. Comparative analsis of basaloid and typical squamous cell carcinoma of the oesophagus: a molecular biological and immunohistochemical study. J. Path., v.193, n.1, p.155-61, Feb. 2001.

91. PARTRIDGE, M. et al. New insights into p53 protein stabilisation in oral squamous cell carcinoma. Oral Oncol., v.35, n.1, p.45-55, Jan. 1999.

92. PAULINO, A.F.G. et al. Basaloid squamous cell carcinoma of the head and neck. Laryngoscope, v.110, n.9, p.1479-82, Sept. 2000.

93. PENA, J.C. et al. Bcl- $\mathrm{X}_{\mathrm{L}}$ and Bcl-2 expression in squamous cell carcinoma of the head and neck. Cancer, v.85, n.1, p.164-70, Jan. 1999.

94. PINDBORG, J.J. et al. Histological typing of cancer and precancer of the oral mucosa. 2 ed. Berlin, Springer, 1997 87p. (World Health Organization International Histological Classification of Tumors).

95. RASLAN, W.F. et al. Basaloid squamous cell carcinoma of the head and neck: a clinicopathologic and flow cytometric study of 10 new cases with review of english literature. Amer. J. Otolaryng., v. 15, n.3, p.204-11, May/June 1994.

96. RAVI, D. et al. Apoptosis, angiogenesis and proliferation: trifunctional measure of tumor response to radiotherapy for oral cancer. Oral Oncol., v.37, n.2, p.164-71, Feb. 2001.

97. REED, J.C. et al. Regulation of bcl-2 proto-oncogene expression during normal human lymphocytes proliferation. Science, v. 236, p.1295-9, June 1987

98. REED, J.C. Bcl-2 and regulation of programmed cell death. J. cell Biol., v.124, n.1/2, p.16, Jan. 1994.

99. REED, J.C. Mechanisms of apoptosis. Amer. J. Path., v.157, n.5 p.1415-30, Nov. 2000. 
100. SARBIA, M. et al. Basaloid squamous cell carcinoma of the esophagus. Diagnosis and prognosis. Cancer, v.79, n.10, p.1871-8, May 1997.

101. SARBIA, M. et al. Expression of Bcl-2 and amplification of c-myc are frequent in basaloid squamous cell carcinoma of the esophagus. Amer. J. Path., v.155, n.4, p.1027-32, Oct. 1999.

102. SCHOELCH, M.L. et al. Apoptosis-associated proteins and development of oral squamous cell carcinoma. Oral Oncol., v.35, n.1, p.77-85, Jan. 1999.

103. SCHOELCH, M.L. et al. Cell cycle proteins and the development of oral squamous cell carcinoma. Oral Oncol., v.35, n.3, p.333-42, May 1999.

104. SEDLAK et al. Multiple bcl-2 family members demonstrate selective dimerizations with Bax. Proc. natl. Acad. Sci., v.92, n.17, p.7834-8, 1995.

105. SEIDMAN, J.D. et al. Basaloid squamous carcinoma of the hypopharyx and larynx associated with second primary tumors. Cancer, v.68, n.7, p.1545-9, Oct. 1991.

106. SELVAKUMARAN, M. et al. Immediate early up-regulation of bax expression by p53 but not TGF $\beta 1$ : a paradigm for distinct apoptotic pathways. Oncogene, v.9, p.1791-8, 1994.

107. SEROTA, A.I. Anal cloacogenic carcinoma. Classification and clinical behavior. Arch. Surg., v.116, n.4, p.456-9, Apr. 1981.

108. SHAHNAVAZ, S.A. et al. p53 gene mutations in sequential oral epithelial dysplasias and squamous cell carcinomas. J. Path., v.190, n.4, p.417-22, Mar. 2000.

109. SHIN, D.M. et al. Sequential increases in proliferating cell nuclear antigen expression in head and neck tumorigenesis: a potential biomarker. J. Natl. Cancer Inst., v.85, n.12, p.971-8, June 1993.

110. SHIM, D.M. et al. p53 protein accumulation and genomic instability in head and neck multistep tumorigenesis. Cancer Epidem. Biomarkers Prev., v. 10, n.6, p.6039, June 2001.

111. SITTEL, C. et al. Prognostic significance of Ki-67 (MIB1), PCNA and p53 in cancer of the oropharynx, and oral cavity. Oral Oncol., v.35, n.6, p.583-9 Nov. 1999.

112. SOINI, Y. et al. Endothelial nitric oxide synthase is strongly expressed in malignant mesothelioma but does not associate with vascular density or the expression of VEGF, FLK1 or FLT1. Histopathology, v.39, n.9, p.179-86, 2001. 
113. STAIBANO, S. et al. Overexpression of ciclin-D1, bcl-2, and bax proteins, proliferation cell nuclear antigen (PCNA), and DNA-ploidy in squamous cell carcinoma of the oral cavity. Human Pathol., v.29, n.11, p.1189-94, Nov. 1998.

114. STATACORP. 2001. Stata statistical software: Release 7.0 College station, TX: Stata corporation.

115. STEINBECK, R.G. et al. DNA content and PCNA immunoreactivity in oral precancerous and cancerous lesions. Oral Oncol., v.29B, n.4, p.279-84, Oct. 1993.

116. STOLL, C.; BARETTON, G.; LÖHRS, U. The influence of p53 and associated factors on the outcome of patients with oral squamous cell carcinoma. Virchows Arch., v.443, p427-33, 1998.

117. STOLL, C. et al. Prognostic significance of apoptosis and associated factors in oral squamous cell carcinoma. Virchows Arch., v.436, n.2, p.102-8, Feb. 2000.

118. STÖRKEL, S. et al. EGFR and PCNA expression in oral squamous cell carcinomas a valuable tool in estimating the patient's prognosis. Oral Oncol., v.29B, n.4, p.273-77, Oct. 1993.

119. SUDBO, et al. Prognostic value of gragh theory-based tissue architecture analysis in carcinomas of the tongue. Lab. Invest., v.80, n.12, p.1881-9, 2000.

120. TAKUBO, K. et al. Basaloid-squamous carcinoma of the esophagus with marked deposition of basement membrane substance. Acta Pathol. Jpn., v.41, n.1, p.5964, Jan. 1991.

121. TATEMOTO, Y. et al. Expression of p53 and p21 proteins in oral squamous cell carcinoma: correlation with lymph node metastasis and response to chemotherapy. Path. Res. Pract., v.194, n.2, p.821-30, Dec. 1998.

122. TNM Classificação dos tumores malignos/Ministério da Saúde, Secretaria de Assistência à Saúde, Instituto Nacional do Câncer, Rio de Janeiro, Coordenação

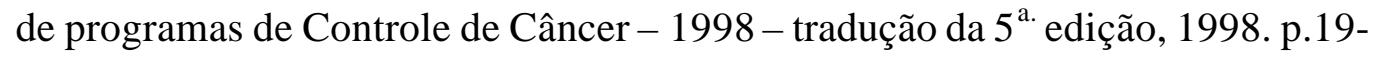
55: tumores da Cabeça e Pescoço.

123. TSANG, W.Y.W. et al. Basaloid-squamous carcinoma of the upper aerodigestive tract and so-called adenoid cystic carcinoma of the oesophagus: the same tumor type?

Histopathology, v.19, n.1, p.35-46, July 1991. 
124. TSANG, W.Y.W.; CHAN,J.K.C. Basaloid-squamous carcinoma of the upper aerodigestive tract. Histopathology, v.20, n.5, p.462, May 1992.

125. TSUJI, T. et al. Measurement of proliferating cell nuclear antigen (PCNA) and its clinical application in oral cancers. Int. J. oral Maxillofac. Surg., v.21, n.6, p.369-72, Dec. 1992.

126. TSUJI, T. et al. The significance of PCNA and p53 protein in some oral tumors. J.oral Path. Med., v.24, n.3, p.221-5, June 1995.

127. TSUJIMOTO, Y; CROCE, C.M.. Analysis of the structure, transcripts, and proteins products of bcl-2 gene involved in human follicular lymphoma. Proc. nat. Acad. Sci., v.14, p.5214-8, July 1986.

128. ÜNAL, Ö.F.; AYHAN, A.; HOSAL, A.S. Prognostic value of p53 expression and histopathological parameters in squamous cell carcinoma of oral tongue. $\mathbf{J}$. Laryngol. Otol., v.113, n.5, p.446-50, May 1999.

129. VAIRO, G.; INNES, K.M.; ADAMS, J.M. Bcl-2 has a cycle inhibitory function separable from its enhancement of cell survival. Oncogene, v.13, p.1511-9, 1996.

130. VAUX, D.L.; CORY, S.; ADAMS, J.M. Bcl-2 gene promotes haemetopoietic cell survival and cooperates with c-myc to immortalize pre-B cells. Nature, v.335, n.6, p.440-2, Sept. 1988.

131. WAIN, S.L. et al. Basaloid-squamous carcinoma of the tongue, hypopharynx, and larynx: report of 10 cases. Human Pathol., v.17, n.11, p.1158-66, Nov. 1986.

132. WEDENBERG, C. et al. Basaloid squamous cell carcinoma of the maxilla. Oral Oncol., v.33, n.2, p.141-4, Mar. 1997.

133. WIENEKE, J.A.; THOMPSON, L.D.R.; WENING, B.M. Basaloid squamous cell carcinoma of the sinonasal tract. Cancer, v.85, n.4, p.841-54, Feb. 1999.

134. WINZENBURG, S.M. et al. Basaloid squamous carcinoma: a clinical comparasion of two histological types with poorly differentiated squamous cell carcinoma. Otolaryng. Head Neck Surg., v.119, n.5, p.471-5, Nov. 1998.

135. XIE, X. et al. The prognostic value of spontaneous apoptosis, Bax, Bcl-2 and p53 in oral squamous cell carcinoma of the tongue. Cancer, v.86, n.6, p.913-20, Sept. 1999. 
136. XIE, X. et al. Prognostic significance of proliferative and apoptotic markers in oral tongue squamous cell carcinoma. Oral Oncol., v.35, n.2, p.502-9, Sept. 1999.

137. YAN, J.J.; TZENG, C.C.; JIN, Y.T. Overexpression of p53 protein in squamous cell carcinoma of the buccal mucosa and tongue in Taiwan: an immunohistochemical and clinicopathological study. J.oral Path. Med., v.25, n.2, p.55-9, Feb. 1996.

138. YAO, L.; IWAI, M.; FURUTA, I. Correlation of bcl-2 and p53 expression with the clinicopathological features in tongue squamous cell carcinomas. Oral Oncol., v.35, n.1, p.56-62, Jan. 1999. 
ABSTRACT 


\section{ORAL BASALOID SQUAMOUS CELL CARCINOMA: ANALYSIS OF THE CLINICAL BEHAVIOR, PROGNOSIS, AND EXPRESSION OF PCNA, p53, BAX AND BCL-X}

Basaloid squamous cell carcinoma (BSCC) has been recognized as an agressive variant of conventional squamous cell carcinoma (SCC), that arises predominantly in the base of the tongue, hypopharynx and larynx. A total of 776 cases of surgically excised primary oral squamous cell carcinomas from the files of Otohinolaryngology, Head and Neck Surgery, and Pathology Departments of the Cancer Hospital A.C. Camargo, from 1970 to 2000 were retrospectively reviewed. Seventeen cases of BSC were identified and clinically compared with 27 poorly differentiated SCC, with equivalent localization and clinical stage using the following parameters: patient gender, age, race, tobacco and alcohol abuse, stage by the TNM-UICC, localization, lymph nodes involvement, treatment, local and cervical recurrences, distant metastasis and second primary tumors. In addition, we investigated the morphologic features and the expression of proliferative and apoptose markers: PCNA, p53, Bax and Bcl-X. The 5 and 10-year survival rates were calculated by Kaplan-Meier method and the prognostic value of the clinical and microscopic variables was obtained by Cox regression models. The histopathologic analysis showed that BSCC was arranged in solid lobules with abundant comedo-type necrosis, peripheral cells with nuclear palisading, microcystic spaces, stromal and intratumoral hialinosis, tumor/stroma disruption and association with squamous cell component. No statistically significant differences were found between group BSSC and SCC, with regard to clinical features and immunohistochemical reactivity for antibodies PCNA, p53 and Bcl-X. In comparison with SCC, BSCC group showed higher Bax score $(p=0,031)$. The 5-year and 10-year overall survival, cancer specific survival and disease free survival rates showed no significant differences between BSC and SCC groups. The $\mathbf{N}$ clinical stage presented an independent prognostic factor for the oral BSC and SCC patients. The histological features and immunohistochemical markers: PCNA, p53, Bax, and Bcl-X, showed no prognostic value. These results suggest that the clinical and biologic course of BSCC is similar to the SCC when clinical stage, site and treatment are matched. In this way, patients presenting these tumors can undergo the same therapeutical protocols. 